November 2004 • NREL/TP-550-33180

\title{
Energy Performance Evaluation of an Educational Facility: The Adam Joseph Lewis Center for Environmental Studies, Oberlin College, Oberlin, Ohio
}

S.D. Pless and P.A. Torcellini
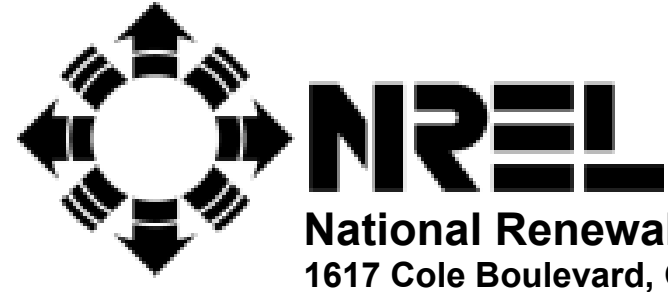

National Renewable Energy Laboratory 1617 Cole Boulevard, Golden, Colorado 80401-3393 303-275-3000 • www.nrel.gov

Operated for the U.S. Department of Energy Office of Energy Efficiency and Renewable Energy by Midwest Research Institute • Battelle 


\section{Energy Performance Evaluation of an Educational Facility: The Adam Joseph Lewis Center for Environmental Studies, Oberlin College, Oberlin, Ohio}

S.D. Pless and P.A. Torcellini

Prepared under Task No. BEC3.4001

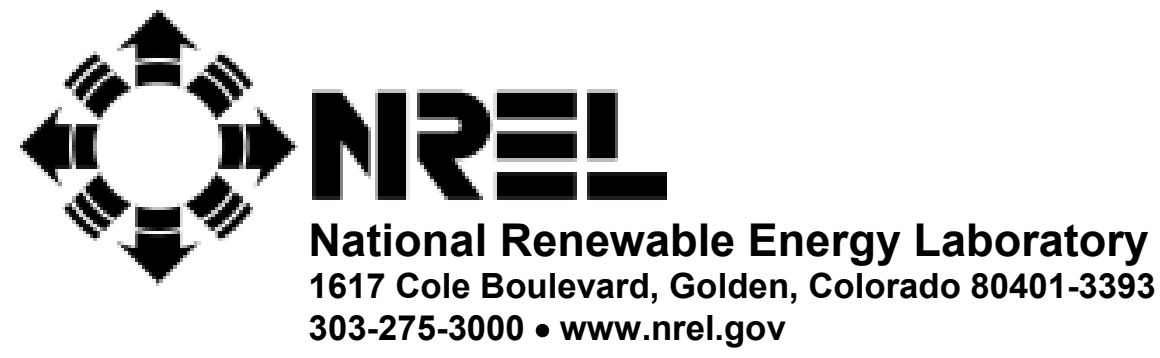

Operated for the U.S. Department of Energy Office of Energy Efficiency and Renewable Energy by Midwest Research Institute • Battelle Contract No. DE-AC36-99-G010337 


\section{NOTICE}

This report was prepared as an account of work sponsored by an agency of the United States government. Neither the United States government nor any agency thereof, nor any of their employees, makes any warranty, express or implied, or assumes any legal liability or responsibility for the accuracy, completeness, or usefulness of any information, apparatus, product, or process disclosed, or represents that its use would not infringe privately owned rights. Reference herein to any specific commercial product, process, or service by trade name, trademark, manufacturer, or otherwise does not necessarily constitute or imply its endorsement, recommendation, or favoring by the United States government or any agency thereof. The views and opinions of authors expressed herein do not necessarily state or reflect those of the United States government or any agency thereof.

Available electronically at http://www.osti.gov/bridge

Available for a processing fee to U.S. Department of Energy and its contractors, in paper, from:

U.S. Department of Energy

Office of Scientific and Technical Information

P.O. Box 62

Oak Ridge, TN 37831-0062

phone: 865.576.8401

fax: 865.576.5728

email: mailto:reports@adonis.osti.gov

Available for sale to the public, in paper, from:

U.S. Department of Commerce

National Technical Information Service

5285 Port Royal Road

Springfield, VA 22161

phone: 800.553 .6847

fax: 703.605.6900

email: orders@ntis.fedworld.gov

online ordering: http://www.ntis.gov/ordering.htm 


\section{Acknowledgments}

The U.S. Department of Energy's Office of Energy Efficiency and Renewable Energy's Building and Solar Technologies Programs funded this research effort through the High-performance Building's initiative (HPBi) and the PV for Buildings tasks. HPBi supported the energy performance analysis and the Solar Program supported the PV system analysis. Oberlin College and the Environmental Studies Department provided funding for data acquisition equipment and access to the building. Special thanks go to Oberlin College Environmental Studies professors John Petersen and David Orr, and to Facilities Planner Leo Evans for their assistance and guidance with this project. Thanks also to Ed Hancock of Mountain Energy Partnership for his invaluable contributions to the monitoring and analysis effort. The authors would also like to thank those who reviewed this document: John Ryan and Dru Crawley at DOE; Mike McCabe, Navigant Consulting; Michael Deru, Lauren Poole, and Brent Griffith at NREL; Nadav Malin at Building Green, Inc; David Orr and John Peterson at Oberlin College; and Professor John Daily of the University of Colorado Mechanical Engineering Department. 


\section{Table of Contents}

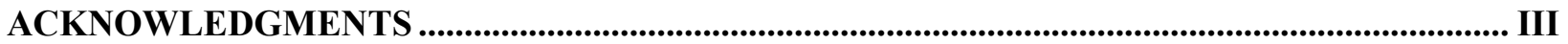

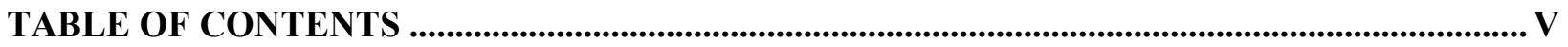

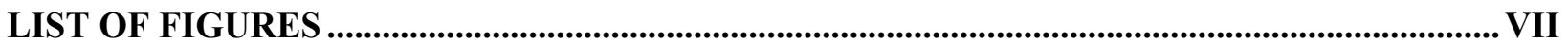

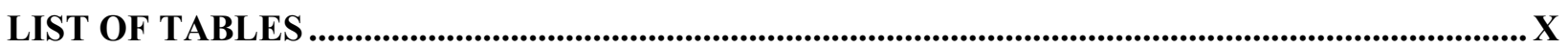

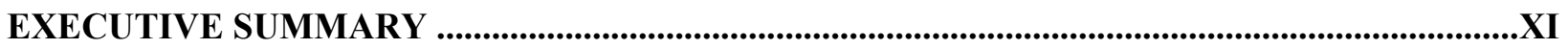

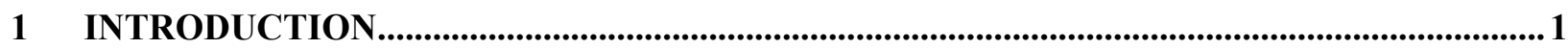

1.1 ENERGY USE IN COMMERCIAL BUILDINGS IN THE UNITED STATES .......................................... 1

1.2 HIGH-PERFORMANCE BUILDINGS RESEARCH OBJECTIVES …............................................. 1

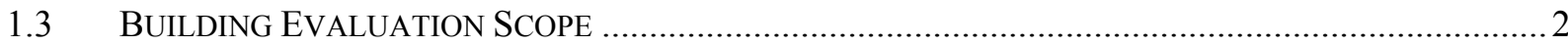

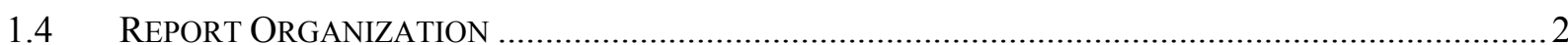

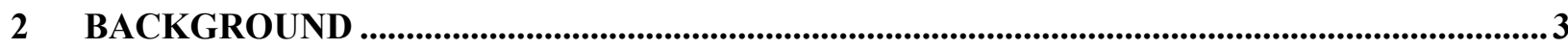

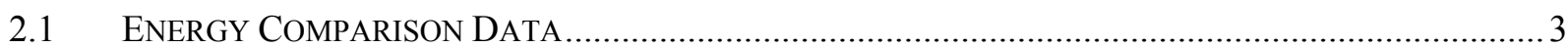

2.2 FIRST YEAR ENERGY PERFORMANCE - LEWIS CENTER ...................................................... 4

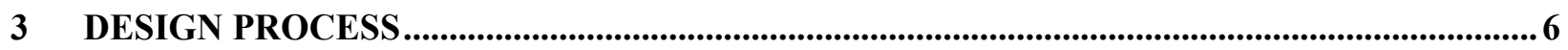

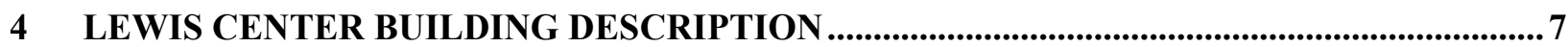

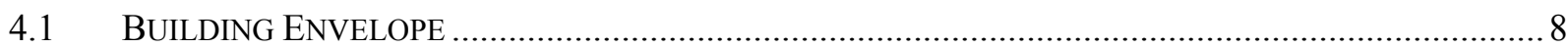

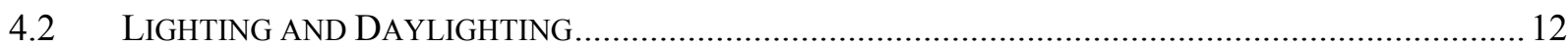

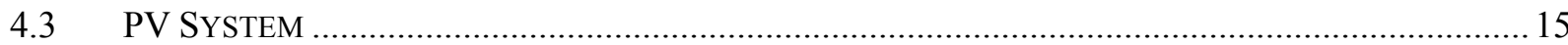

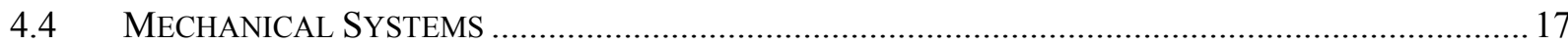

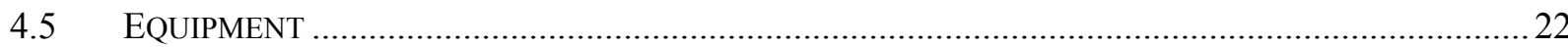

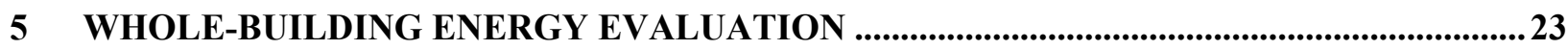

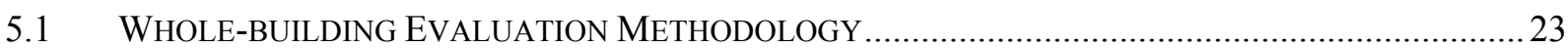

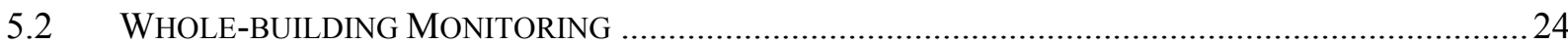

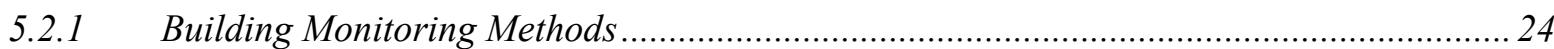

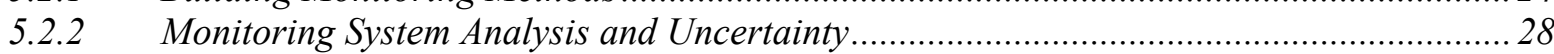

5.2.3 March 2001-February 2002 Measured Data Analysis.................................................... 30

5.2.4 March 2002-February 2003 Measured Data Analysis.................................................... 40

5.3 DEVELOPMENT OF BUILDING ENERGY MODELS...................................................................... 45

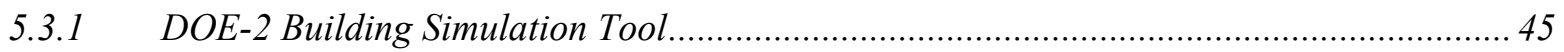

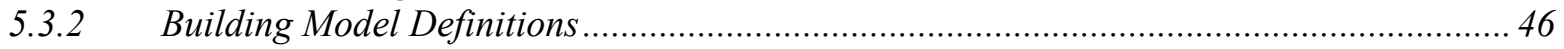

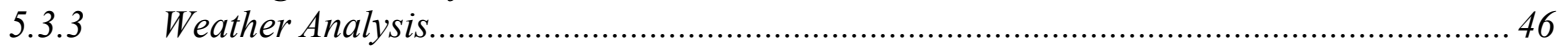

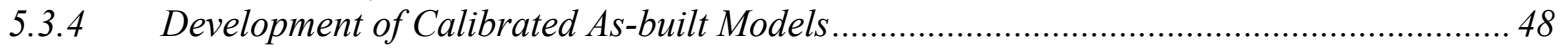

5.3.5 Development of Base-Case Model ................................................................................... 52

5.4 WHOLE-BUILDING ENERGY PERFORMANCE RESULTS, 2001-2002 _....................................... 54

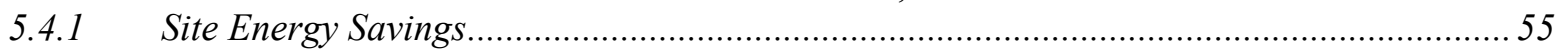

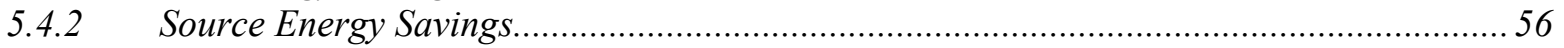

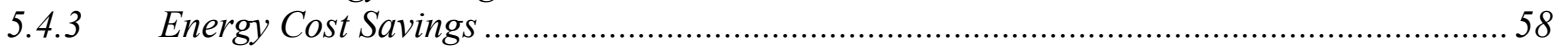

5.5 WhOlE-BUILDING ENERGY PERFoRMANCE RESUlTS, 2002-2003 ....................................... 59 


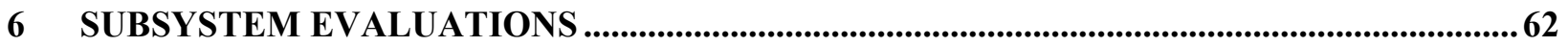

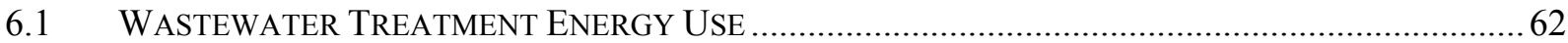

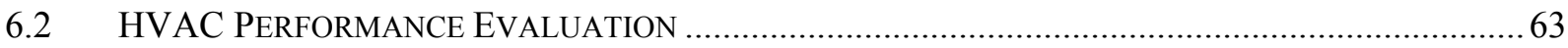

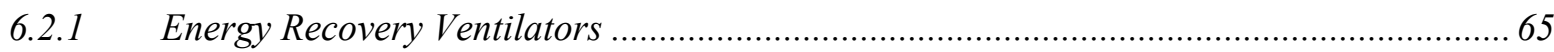

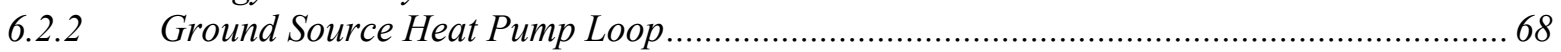

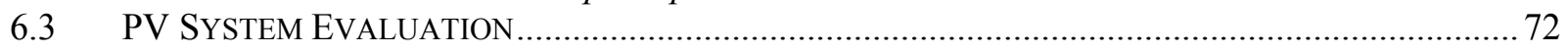

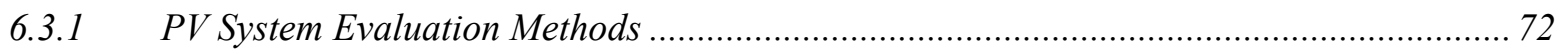

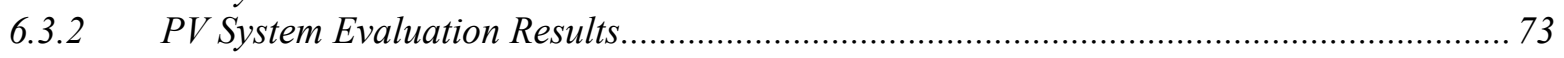

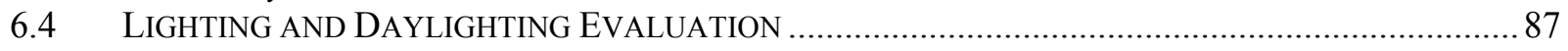

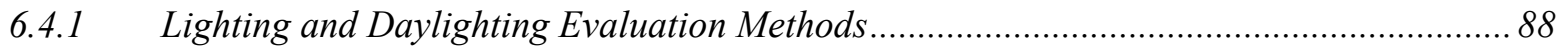

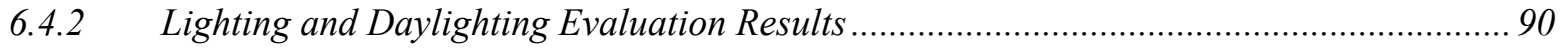

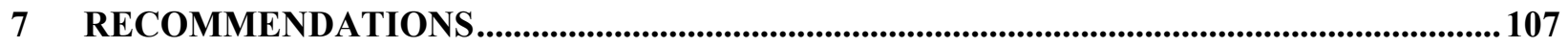

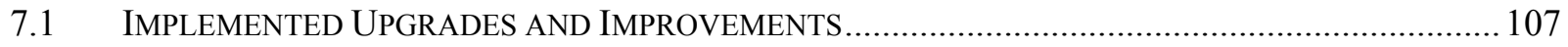

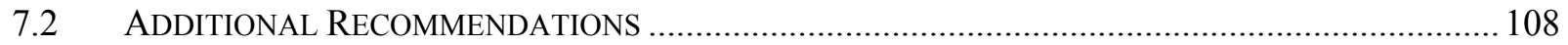

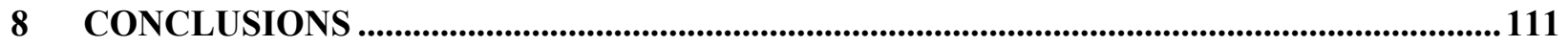

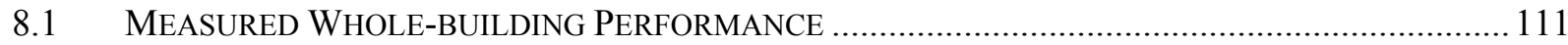

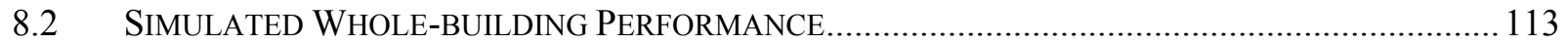

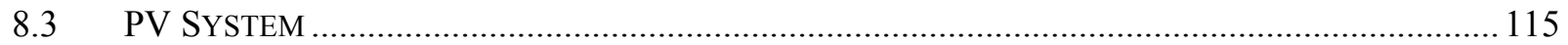

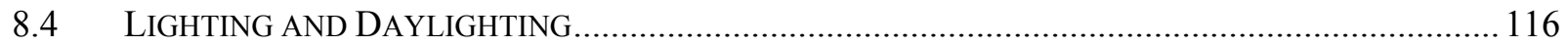

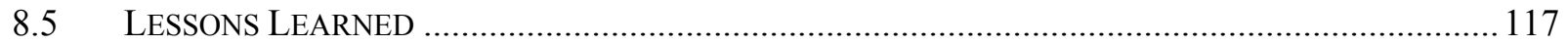

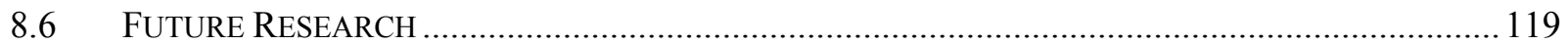

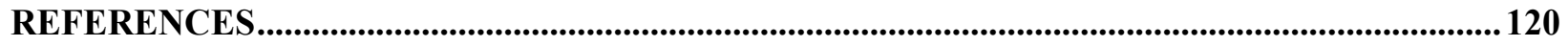

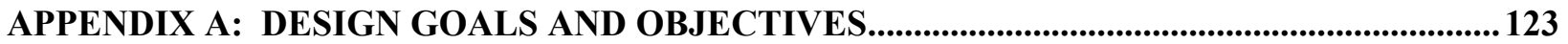

APPENDIX B: CLASSROOM ASSIGNMENTS IN THE ADAM JOSEPH LEWIS CENTER,

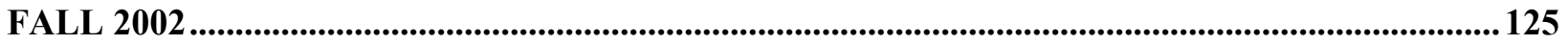

APPENDIX C: BUILDING PERFORMANCE SUMMARY DATA................................................126

APPENDIX D: SEASONAL DAYLIGHTING ANALYSIS ............................................................. 128

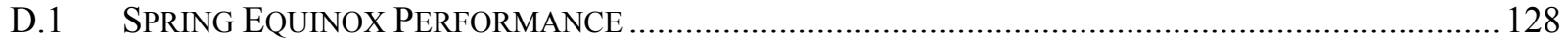

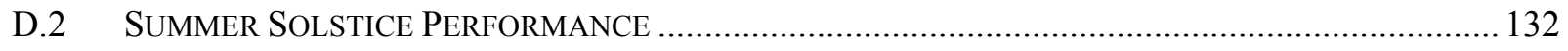

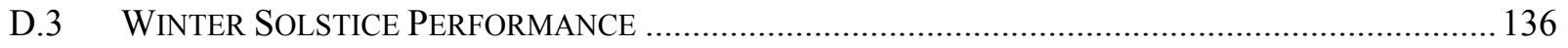




\section{List of Figures}

Figure ES-1 Annual site energy performance of building models and measured data...........................xii

Figure 2-1

Figure 2-2

Figure 2-3

Figure 4-1

Figure 4-2

Figure 4-3

Figure 4-4

Figure 4-5

Figure 4-6

Figure 4-7

Figure 4-8

Figure 4-9

Figure 4-10

Figure 4-11

Figure 4-12

Figure 4-13

Figure 4-14

Figure 4-15

Figure 4-16

Figure 4-17

Figure 5-1

Figure 5-2

Figure 5-3

Figure 5-4

Figure 5-5

Figure 5-6

Figure 5-7

Figure 5-8

Figure 5-9

Figure 5-10

Figure 5-11

Figure 5-12

Figure 5-13

Figure 5-14

Figure 5-15

Figure 5-16

Figure 5-17

Figure 5-18

Figure 5-19

Figure 5-20

Figure 5-21

Figure 5-22

1999 Midwest site energy intensity by building type, with Oberlin College average ............ 3

U.S. academic building site energy consumption by end use, 1995 ................................... 4

Lewis Center daily average site energy consumption and production, January 2000

through February 2001 5

Significant high-performance building technology features (NREL 2004) ......................... 7

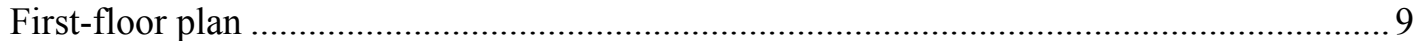

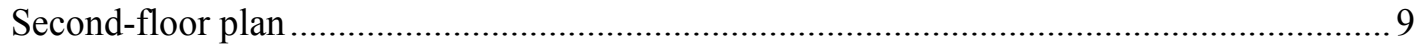

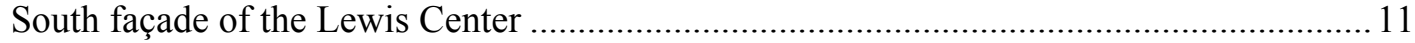

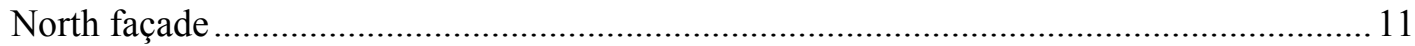

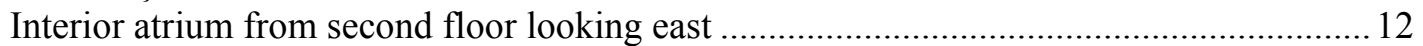

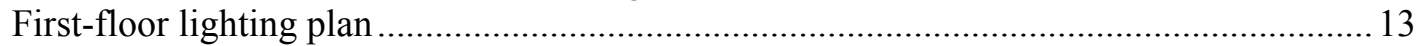

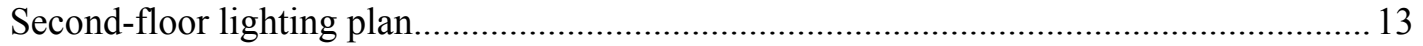

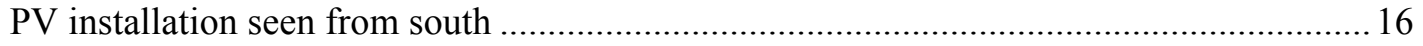

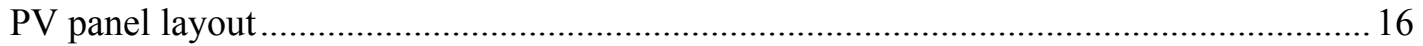

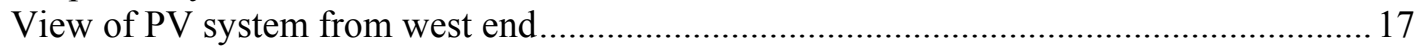

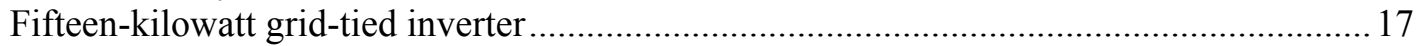

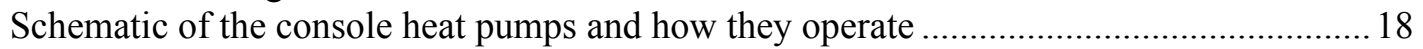

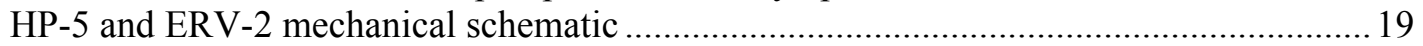

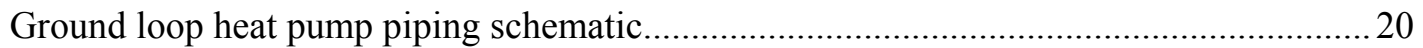

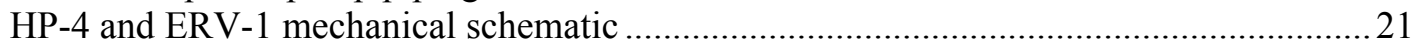

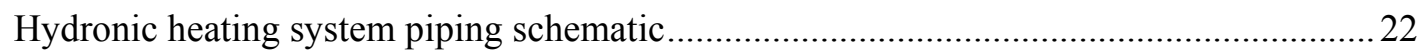

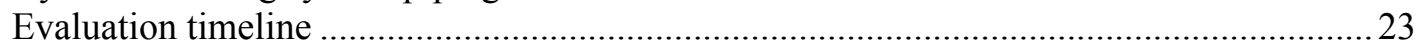

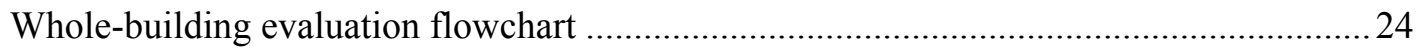

Single-line building electrical system plan and DAS meter locations ...............................25

Single-line PV electrical system plan and data acquisition meter locations ........................2 27

$\mathrm{X}-\mathrm{Y}$ plot of calculated building electricity utility supply (CM1) versus utility meter

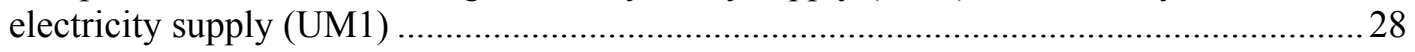

Average daily energy performance, March 1, 2001 through February 28, 2002 ................. 32

Energy consumption end use summary, March 1, 2001 through February 28, 2002 2.......... 32

Total electricity consumption load shape by season (without PV production) ......................33

Daily average net electricity consumption load shape by season, with PV production ........ 34

Monthly energy cost by charge type, March 2001-February 2002 .....................................35

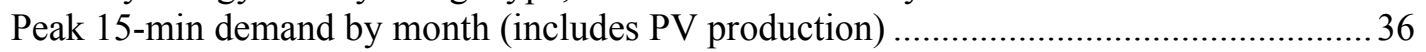

Peak August utility demand, PV production, and end use (August 9, 2001) ........................ 37

Peak heating season utility demand, PV production, and end use (Jan. 4, 2002) ................ 38

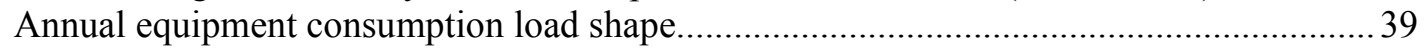

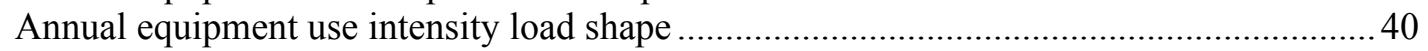

Daily average energy use and production, March 2001 through February 2003 ................. 41

Daily HVAC energy use as a function of ambient temperature, second and third year of operation

Daily EB-1 and HP-4 energy use as a function of ambient temperature, March 2001

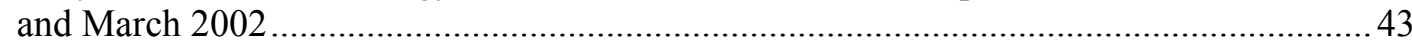

Upgraded hot-water and ground source heat pump piping schematic .............................. 44

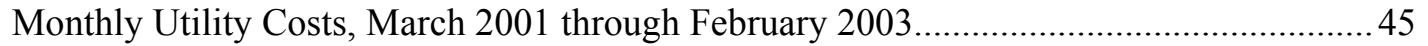

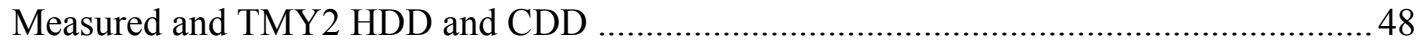

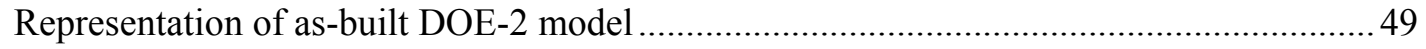


Figure 5-23 Results of the calibrated As-built March 01-February 02 model: measured weather simulated and measured HVAC, equipment, and lighting ............................................. 51

Figure 5-24 Representation of DOE-2 solar-neutral, Base-case model...............................................53

Figure 5-25 Annual site energy consumption of ASHRAE 90.1-2001 TMY2 Base case versus

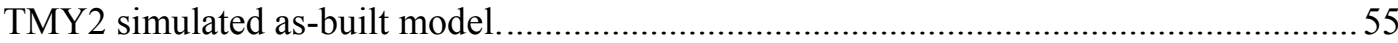

Figure 5-26 Annual source energy consumption of ASHRAE 90.1-2001 Base case versus TMY2

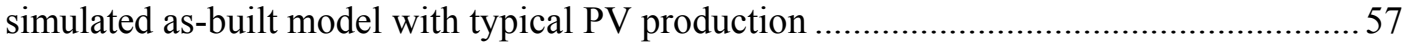

Figure 5-27 Monthly electricity charges, Base case and measured 2001-2002 ................................59

Figure 5-28 Annual Site Energy Consumption and production, TMY2 Base case and

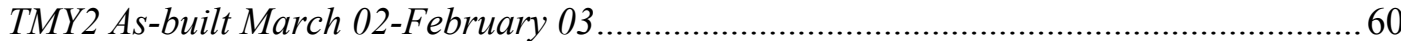

Figure 6-1 Daily HVAC energy consumption versus average outdoor temperature ...........................63

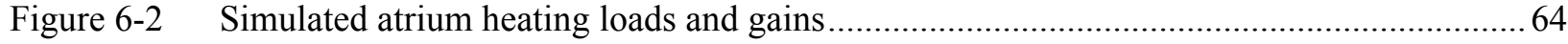

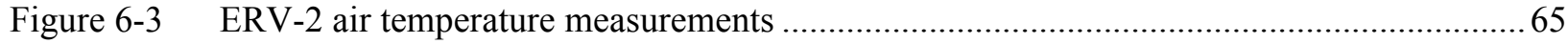

Figure 6-4 Calculated ERV-2 energy recovery as a function of outdoor temperature ........................66

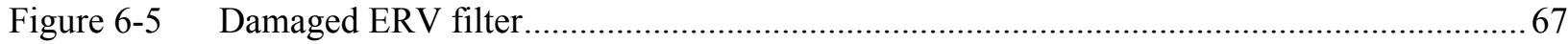

Figure 6-6 Published ERV performance (Greenheck 2003) .......................................................67

Figure 6-7 Frequency of hourly average EWT from the ground loop ................................................69

Figure 6-8 HP-4 and HP-5 published heating and cooling performance ........................................ 70

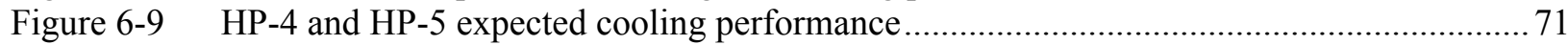

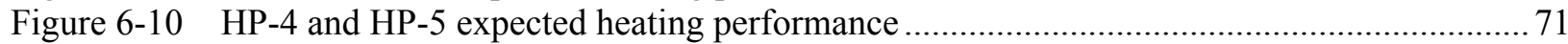

Figure 6-11 Single-line PV electrical system plan and data acquisition meter locations ...................... 73

Figure 6-12 Measured versus simulated daily average PV production, March 1, 2001

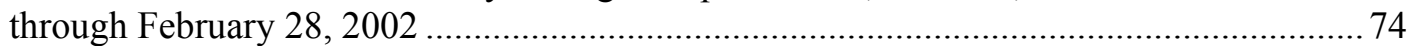

Figure 6-13 Average hourly power profile by month for PV production, March 1, 2001

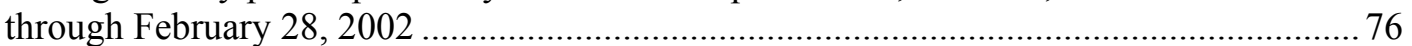

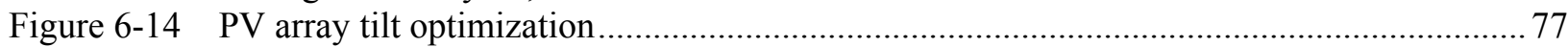

Figure 6-15 Measured versus published PV inverter-transformer efficiency, March 1, 2001

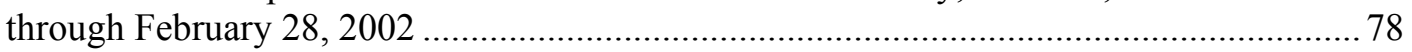

Figure 6-16 Measured, average, and minimum PV AC electricity generation efficiency,

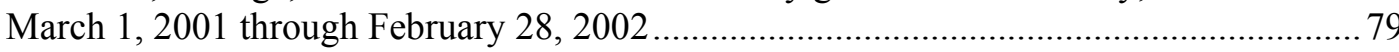

Figure 6-17 DC subarray A current as a function of incident solar radiation, March 1, 2001 through

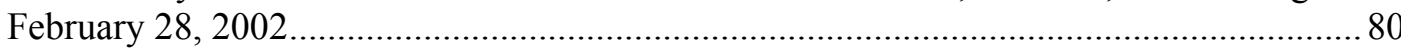

Figure 6-18 DC subarray A voltage as a function of cell temperature, March 1, 2001

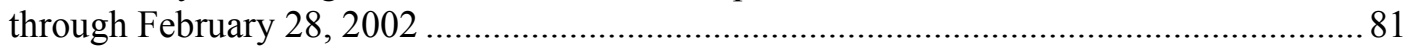

Figure 6-19 PV array partially covered with snow .................................................................... 82

Figure 6-20 Inverter shutdown example with minute and hourly PV performance, April 28, 2001 .......83

Figure 6-21 Net building use and nighttime PV system consumption example, November 13

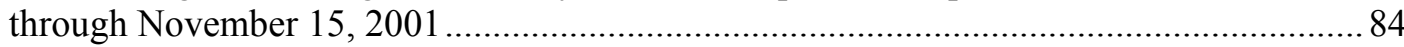

Figure 6-22 PV single-panel published power-voltage curves at varying cell temperatures.................. 86

Figure 6-23 Subarray A power-voltage/current-voltage curve trace comparison.................................8 87

Figure 6-24 Second-floor continuous illuminance measurement locations (numbered circles) ............89

Figure 6-25 Second-floor corridor and classroom handheld illuminance measurement locations ..........89

Figure 6-26 First-floor atrium and classroom handheld illuminance measurement locations ................ 90

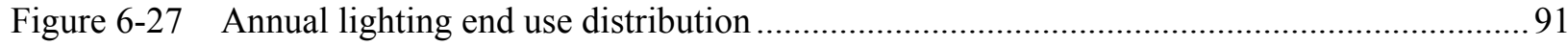

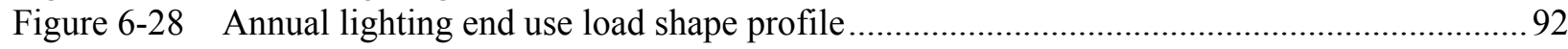

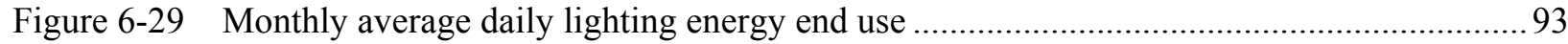

Figure 6-30 Second-floor corridor daylighting and atrium daylighting............................................ 95

Figure 6-31 Lighting and daylighting design savings for indoor lights.......................................... 96

Figure 6-32 Average 15-min office illuminance versus outdoor illuminance .................................... 97

Figure 6-33 Average second floor corridor 15-min illuminance versus outdoor illuminance................98 
Figure 6-34 North row average seasonal second-floor classroom illuminance versus outdoor

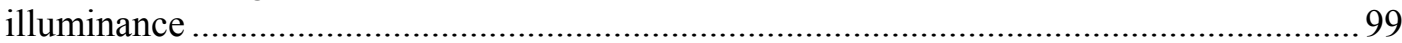

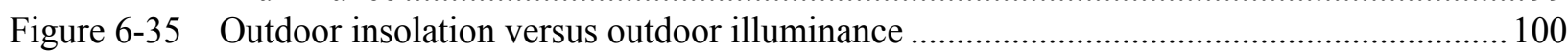

Figure 6-36 Outdoor annual daytime illuminance distribution......................................................... 101

Figure 6-37 Outdoor monthly daytime cumulative illuminance distribution ................................... 102

Figure 6-38 Emergency lights monthly load shape profile .......................................................... 103

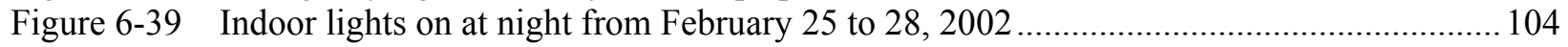

Figure 6-40 Second-floor classroom illuminance measurements with electric lighting only

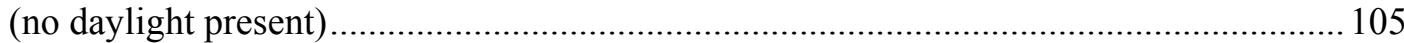

Figure 7-1 Upgraded radiant and ground source heat pump loop piping schematic ........................ 107

Figure 7-2 Current and ARI-330 rated heat pump heating and cooling efficiencies .......................... 109

Figure 7-3 Top down and Top down/bottom up blinds ............................................................... 110

Figure 8-1 Monthly site energy consumption and production, January 2000-February 2003 ........... 111

Figure 8-2 Monthly site energy costs, March 2000 through February 2003 ................................... 112

Figure 8-3 Annual performance for TMY2 2001-2002 Base-case model, as-built models, and

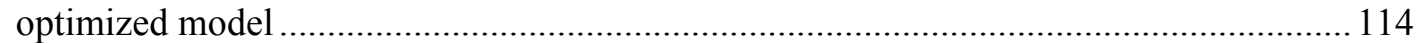

Figure D-1 Outside horizontal illuminance for a typical clear day and a typical cloudy day (March 28 and March 30, 2001, respectively).............................................................. 128

Figure D-2 Second-floor classroom illuminance measurements on a typical clear day ..................... 129

Figure D-3 Spring equinox second-floor shading at midmorning, March 28, 2001 ....................... 130

Figure D-4 Second-floor classroom illuminance measurements on a typical cloudy day .................. 130

Figure D-5 Influence of blinds in first-floor classroom-12:10 to 12:25 p.m. on March 28, $2001 \ldots \ldots .131$

Figure D-6 Measured illuminance in atrium during a variably cloudy day, March 26, 2001 ............. 132

Figure D-7 Outside horizontal illuminance for June 19 and 20, 2001 ........................................... 133

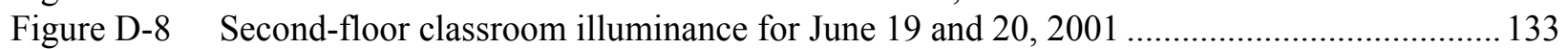

Figure D-9 First-floor classroom illuminance levels at 12:20 p.m. on June 19, 2001 ...................... 134

Figure D-10 Second-floor classroom showing daylighting without electric lights ............................... 135

Figure D-11 First-floor classroom showing daylighting without electric lights................................ 135

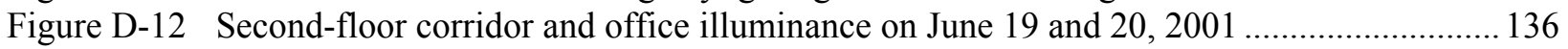

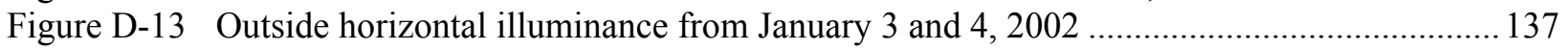

Figure D-14 Second-floor classroom illuminance on January 3, 2002 ........................................... 137

Figure D-15 Second-floor classroom illuminance on January 4, 2002 ............................................ 138

Figure D-16 Second-floor classroom looking west with blinds closed ............................................... 139

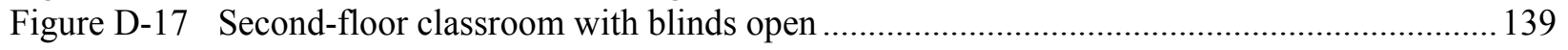




\section{List of Tables}

Table ES-1 Annual Long-term Performance Metrics .........................................................................

Table 4-1 Building Envelope Construction and Thermal Properties (ASHRAE 2001b) .................... 10

Table 4-2

Building Fenestration

Table 4-3

Luminaire Schedule 14

Table 4-4

Lighting Zone Control with End use Measurement Category .....

Table 5-1

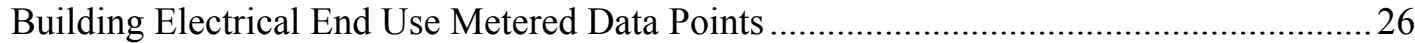

Table 5-2

PV System Metered Data Points

Table 5-3

Measurement Type Accuracy

Table 5-4

Measured Whole-building Results, Second Year of Operation ........................................... 30

Table 5-5

Measured Whole-building Results, Second and Third Year of Operation............................. 42

Table 5-6

TMY2 and Second Year Measured Outdoor Environmental Conditions ............................47

Table 5-7

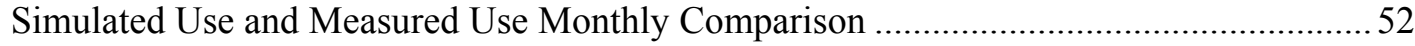

Table 5-8

Table 5-9

Base-case Envelope Minimum Allowable Thermal Characteristics.....................................53

Table 5-10

Table 5-11

Table 5-12

Table 5-13

Table 5-14

Base-case Space Conditions

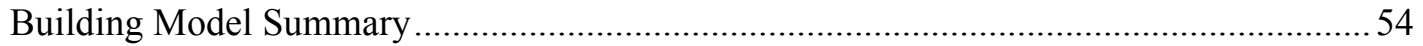

Site Energy Consumption and Savings for the Base case and As-built Model.................... 56

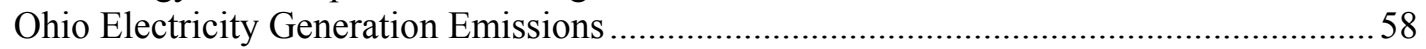

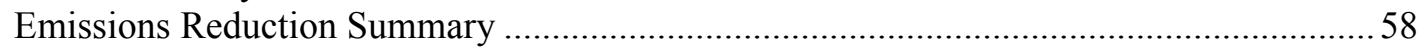

Site Energy Performance for Base case, Second, and Third Year As-built Models ............6 61

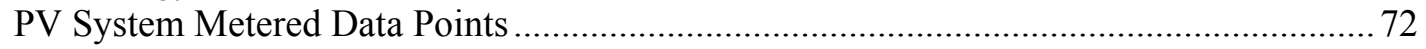

Measured PV Performance Summary, March 1, 2001 through February 28, 2002 ............. 75

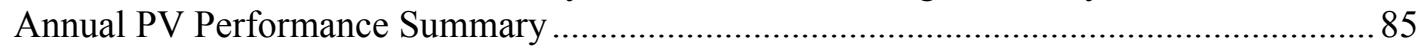

Monthly Lighting Energy Performance Summary, March 2001 through February 2002 .... 93

Base case and Actual Lighting Power Density by Space .................................................. 94

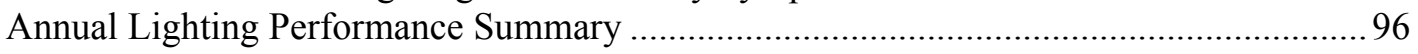

Measured Whole-Building Results: First, Second, and Third Year of Operation............... 112

Annual Energy Performance Summary for Each Building Version ................................ 114

Table 8-2

Performance Degradation Results. 


\section{Executive Summary}

\section{Introduction}

When Oberlin College had the Adam Joseph Lewis Center built in 2000, the staff set out to change campus buildings from energy consumers to energy producers. In addition, they wanted the Lewis Center to serve as a model and teaching aid for students in their Environmental Studies Program. The design team's primary goal for the Lewis Center, a $13,600-\mathrm{ft}^{2}\left(1260-\mathrm{m}^{2}\right)$ building that includes classrooms, offices and an atrium, was to incorporate enough energy-efficient features into the building such that it would export energy to the utility grid. Among the features used were passive solar design, natural ventilation, enhanced thermal envelope, and geothermal heat pumps for heating and cooling. The building also has a roof-integrated photovoltaic (PV) system to allow solar electricity to provide energy to the building.

After the building was constructed, the National Renewable Energy Laboratory (NREL) monitored the building and evaluated its energy performance. NREL used the findings from its analysis to identify and correct problem areas within the building. In addition, monitoring and analysis of the Lewis Center has benefited NREL by furthering its understanding of the processes of whole-building design and building operation. This report documents the energy performance analysis of the Lewis Center conducted after occupancy.

\section{Research Goals and Approach}

NREL's evaluation of the Lewis Center was established with the following goals:

- Evaluate the performance of the building and some of its subsystems.

- Improve the initial performance.

- Document lessons-learned to improve future low-energy buildings.

For the first year, NREL used utility bills to evaluate energy performance. Based on that data, NREL developed a monitoring plan and evaluated the building for two more years (March 1, 2001 until February $28,2003)$. To provide estimates of energy performance based on typical weather data for the area, a calibrated energy model was created to determine average energy performance. For comparison purposes, a reference model was created based on ASHRAE 90.1-2001 energy code for commercial buildings. Using this information, performance metrics for site energy, source energy, and energy cost savings were determined.

\section{Results}

The total site energy for the first year was $47.5 \mathrm{kBtu} / \mathrm{ft}^{2}\left(539 \mathrm{MJ} / \mathrm{m}^{2}\right)$, with energy costs of $\$ 1.20 / \mathrm{ft}^{2}$ $\left(\$ 12.92 / \mathrm{m}^{2}\right)$. Detailed monitoring helped to determine several problem areas that were corrected. For the third year, the site energy usage dropped to $29.8 \mathrm{kBtu} / \mathrm{ft}^{2}\left(338 \mathrm{MJ} / \mathrm{m}^{2}\right)$, with energy costs at $\$ 0.84 / \mathrm{ft}^{2}$ $\left(\$ 9.04 / \mathrm{m}^{2}\right)$. Figure ES-1 shows the annual site energy use and production for the calibrated energy model and reference model, as well as the measured site energy use and production for the first three years of occupancy. Note that the energy use of the calibrated model, which was based the third year of occupancy and long-term weather patterns, is less than the second- and third-year measured energy use. Operational changes and equipment upgrades were made during the second year. The third year was colder than normal. Therefore, the measured performance for the second and third year is higher than the calibrated model in Figure ES-1. 


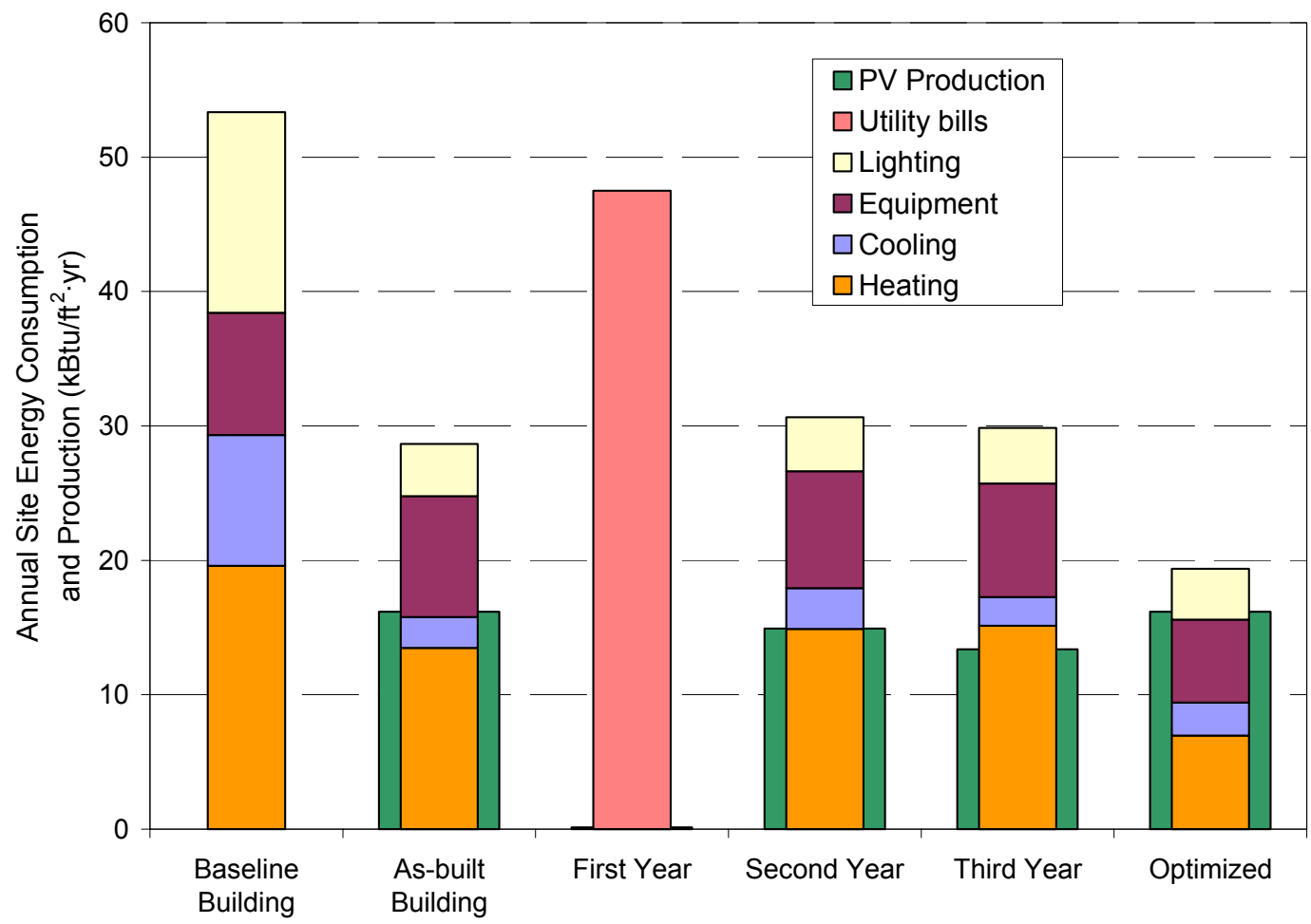

Figure ES-1 Annual site energy performance of building models and measured data

Table ES-1 Annual Long-term Performance Metrics

\begin{tabular}{|l|c|}
\hline \multicolumn{2}{|c|}{ Energy Performance Metric } \\
\hline $\begin{array}{l}\text { Total Site Energy Use Intensity, } \\
\text { calibrated model }\end{array}$ & $\begin{array}{l}27.5 \mathrm{kBtu} / \mathrm{ft}^{2} \\
\left(312 \mathrm{MJ} / \mathrm{m}^{2}\right)\end{array}$ \\
\hline $\begin{array}{l}\text { Percent Site Energy Savings as } \\
\text { compared to Base case }\end{array}$ & $48 \%$ \\
\hline Typical Site PV Production Intensity & $\begin{array}{l}16.2 \mathrm{kBtu} / \mathrm{ft}^{2} \\
\left(184 \mathrm{MJ} / \mathrm{m}^{2}\right)\end{array}$ \\
\hline Percent of Building load met by PV & $59 \%$ \\
\hline Net Site Energy Use Intensity & $\begin{array}{l}11.3 \mathrm{kBtu} / \mathrm{ft}^{2} \\
\left(128 \mathrm{MJ} / \mathrm{m}^{2}\right)\end{array}$ \\
\hline Source Energy Use Intensity & $\begin{array}{l}36.5 \mathrm{kBtu} / \mathrm{ft}^{2} \\
\left(415 \mathrm{MJ} / \mathrm{m}^{2}\right)\end{array}$ \\
\hline Site Purchased Energy Cost Intensity & $\begin{array}{r}\$ 0.84 / \mathrm{ft}^{2} \\
\left(\$ 9.15 / \mathrm{m}^{2}\right)\end{array}$ \\
\hline
\end{tabular}


Further recommendations are presented in this report that have not yet been implemented. Based on optimized models incorporating recommended changes discussed in Section 7, the site energy savings could be increased to $64 \%$, with $85 \%$ of the building load met by the PV system. Based on this information, an additional 30-kW PV system would be required to meet the long-term goal of obtaining a building that is a net energy exporter.

Additional lessons learned were also documented. In general, an academic building in a heating dominated climate can operate as a low energy building, and may be able to approach a net-zero energy building in the near future. However, to achieve a net-zero building, the energy performance will need to be further optimized and a larger PV system installed, which would extend beyond the footprint of the building. Further work is also needed to improve the energy cost savings, as the PV system did not significantly reduce demand charges. Continued improvements and monitoring, combined with advanced controls understanding and implementation, will ensure the Lewis Center operates at its full potential. A detailed list of lessons learned is available in Section 8.5. 


\section{Introduction}

The Adam Joseph Lewis Center for Environmental Studies is a classroom and laboratory building located on the campus of Oberlin College in Oberlin, Ohio. The two-story, 13,600- $\mathrm{ft}^{2}\left(1,260 \mathrm{~m}^{2}\right)$ building was designed to be an energy-efficient model for commercial design and to serve as a teaching tool for students. The design process, guided by Oberlin's environmental studies program, started in February of 1996. Construction began in September of 1998, and the building was ready for occupancy in January of 2000. During the Lewis Center dedication in September of 2000, Clayton Koppes, acting president of Oberlin College and current college dean, described the building as "a laboratory that will showcase environmentally efficient building technologies, operating systems, and sustainable building techniques," adding that "the final result will be a building that uses significantly less energy than typical campus buildings" (Oberlin College 2002). Appendix A includes a summary of the sustainable design goals. One of these goals is the long-term vision of a building that will export more energy than it consumes or a zero-energy building. To accomplish this, Oberlin College designed the Lewis Center to minimize site energy use while producing electricity on-site.

After the building was constructed, Oberlin College contacted the National Renewable Energy Laboratory (NREL) to monitor, evaluate, and document the Lewis Center's energy performance. Their objectives were to:

- Monitor, evaluate, and document energy performance of Lewis Center.

- Improve the energy performance of the Lewis Center.

- Document the lessons learned from the analysis.

NREL researchers were able to use the findings from their analysis to identify and correct problem areas within the building. In addition, monitoring and analysis of the Lewis Center has benefited NREL by furthering its understanding of the processes of whole-building design and building operation.

\subsection{Energy Use in Commercial Buildings in the United States}

The operation of commercial buildings accounts for approximately $18 \%$ of the primary energy consumption in the United States. The total for all residential and commercial buildings is over one third of the primary energy consumption and $70 \%$ of the electricity consumption (DOE 2003). Energy consumption can be expressed as the amount of energy consumed within the building (site energy) or as the sum of the energy directly consumed at the site and the energy consumed in the production and delivery of energy products (primary or source energy). Documenting primary energy consumption is important when emissions from energy sources are of concern. Primary energy used in residential and commercial buildings in the United States results in $35 \%$ of U.S. and $9 \%$ of global carbon dioxide $\left(\mathrm{CO}_{2}\right)$ emissions. Electricity consumption in the commercial building sector has doubled in the last 18 years, and it is expected to increase by another $25 \%$ by 2030 if current growth rates continue (EIA 1998). Reducing site energy consumption in commercial buildings through energy-efficient and renewable building technologies would significantly reduce primary energy consumption in the United States (EIA 1998). Site energy is also a concern for the building owner or those responsible for paying the utility bills.

\subsection{High-Performance Buildings Research Objectives}

The High-Performance Buildings Research Program at NREL conducts research for the U.S. Department of Energy's High-Performance Buildings initiative (HPBi). NREL evaluates commercial buildings from a whole-building perspective to understand the impact of integrated design issues on energy use and costs in commercial buildings. By documenting analysis methodologies and results on new commercial design, NREL is providing direct assistance to industry. NREL's research objectives are to: 
- develop processes for high-performance building design, construction, and operation,

- provide the tools needed to replicate the processes,

- research new technologies for high-performance buildings,

- develop standardized metrics and procedures for measuring building energy performance, and

- measure and document building performance in high-profile examples.

\subsection{Building Evaluation Scope}

The Lewis Center was selected as a technical case study for HPBi research efforts. The NREL HighPerformance Buildings team, in collaboration with Oberlin College Environmental Studies students and faculty, monitored, evaluated, and documented the whole building energy performance of the Lewis Center. This report documents the energy performance analysis of the Lewis Center conducted after occupancy. The evaluation period was March 2001 through February 2003. The first year of building operation was not studied in detail; however, utility data provided overall performance information during this period. NREL also did not study the design process, although performance issues related to design decisions are discussed in this report.

Furthermore, NREL studied the Lewis Center as a complete system, rather than analyzing all of the individual building components. Many of the individual high-performance components have been studied in the past. For example, Shonder, et al. (2000) showed that ground source heat pumps systems in educational buildings in a heating dominated climate are among the lowest energy consuming educational buildings. The evaluation presented in this report focuses on the whole-building performance, with additional analysis of innovative systems, such as the photovoltaic, daylighting, and wastewater systems. Detailed analyses of other specific end uses or specific zones are not part of the whole-building evaluation scope.

\subsection{Report Organization}

This report contains an executive summary, eight primary sections, a list of references, and appendices. Section 2 provides background information, Section 3 details the design process, Section 4 describes the physical components of the Lewis Center; and Section 5 contains whole-building evaluation methods and results. Section 6 discusses the evaluation of specific subsystems and Section 7 and 8 presents the recommendations and conclusions drawn from this study. The appendices contain a summary of the sustainable design goals, a classroom schedule, measured data summary table with monthly electrical end use totals, and additional daylighting analysis. 


\section{Background}

\subsection{Energy Comparison Data}

To fully evaluate the Lewis Center's energy performance, it was important for NREL researchers to have comparison data. NREL began its analysis by examining data collected on thousands of U.S. commercial buildings by the Energy Information Administration (EIA). In 1999, EIA conducted the Commercial Buildings Energy Consumption Survey (CBECS), a national survey that collected information on thousands of building types in the United States, including building characteristics, energy consumption, and energy expenditures for all types of commercial buildings. CBECS concluded educational buildings account for $11 \%$ of all energy used in commercial buildings, or $2 \%$ of all the electricity used in the United States. The survey also showed that all commercial buildings in the Midwest had an average site energy intensity of $90.0 \mathrm{kBtu} / \mathrm{ft}^{2} \cdot \mathrm{yr}\left(1020 \mathrm{MJ} / \mathrm{m}^{2} \cdot \mathrm{yr}\right)$, with educational building site energy intensity averaged over year built and size at $79.1 \mathrm{kBtu} / \mathrm{ft}^{2} \cdot \mathrm{yr}\left(898 \mathrm{MJ} / \mathrm{m}^{2} \cdot \mathrm{yr}\right)$, as shown in Figure 2-1. (The EIA defines site energy intensity as site energy consumption per square foot of total floor space.) The U.S. educational energy expenditure was $\$ 8.0$ billion $/ \mathrm{yr}$, or $\$ 0.93 / \mathrm{ft}^{2} \cdot \mathrm{yr}\left(\$ 10.01 / \mathrm{m}^{2} \cdot \mathrm{yr}\right)$ (EIA 1999).

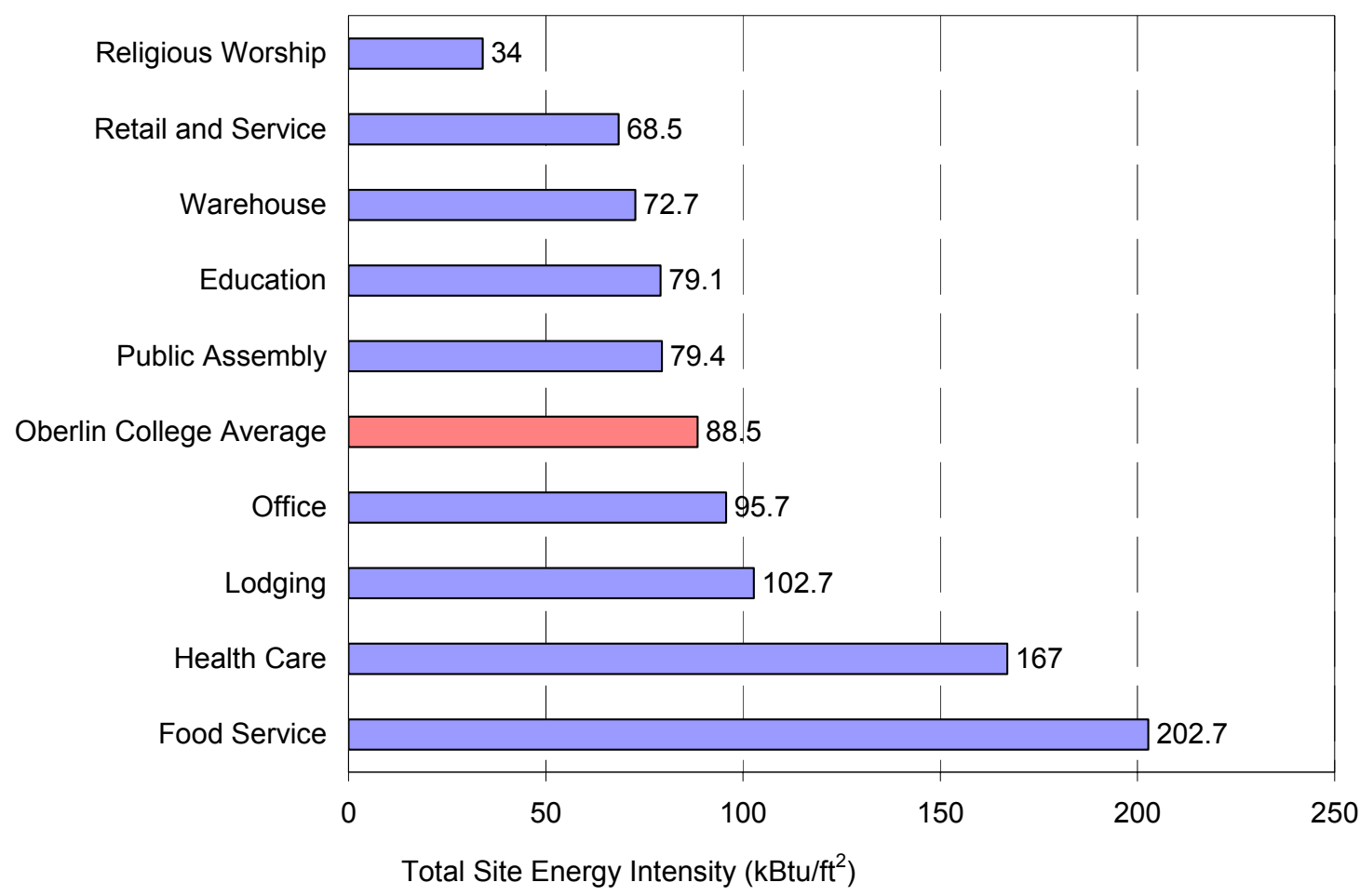

Figure 2-1 1999 Midwest site energy intensity by building type, with Oberlin College average

CBECS determined that educational buildings in the Midwest had an average energy cost intensity of $\$ 0.80 / \mathrm{ft}^{2}\left(\$ 8.61 / \mathrm{m}^{2}\right)$. Overall, CBECS found that educational buildings consumed 649 trillion Btu $(685 \mathrm{TJ})$ of combined site electricity, natural gas, fuel oil, and district steam or hot water, making them the third highest energy consumer of all the commercial building types. Figure 2-2 shows the end use distribution (EIA 1999). The survey also found that the majority of site energy use was for space heating, lighting, and water heating. Cooling energy was considerably less than that of other commercial buildings, as academic buildings are not typically occupied during the summer. 


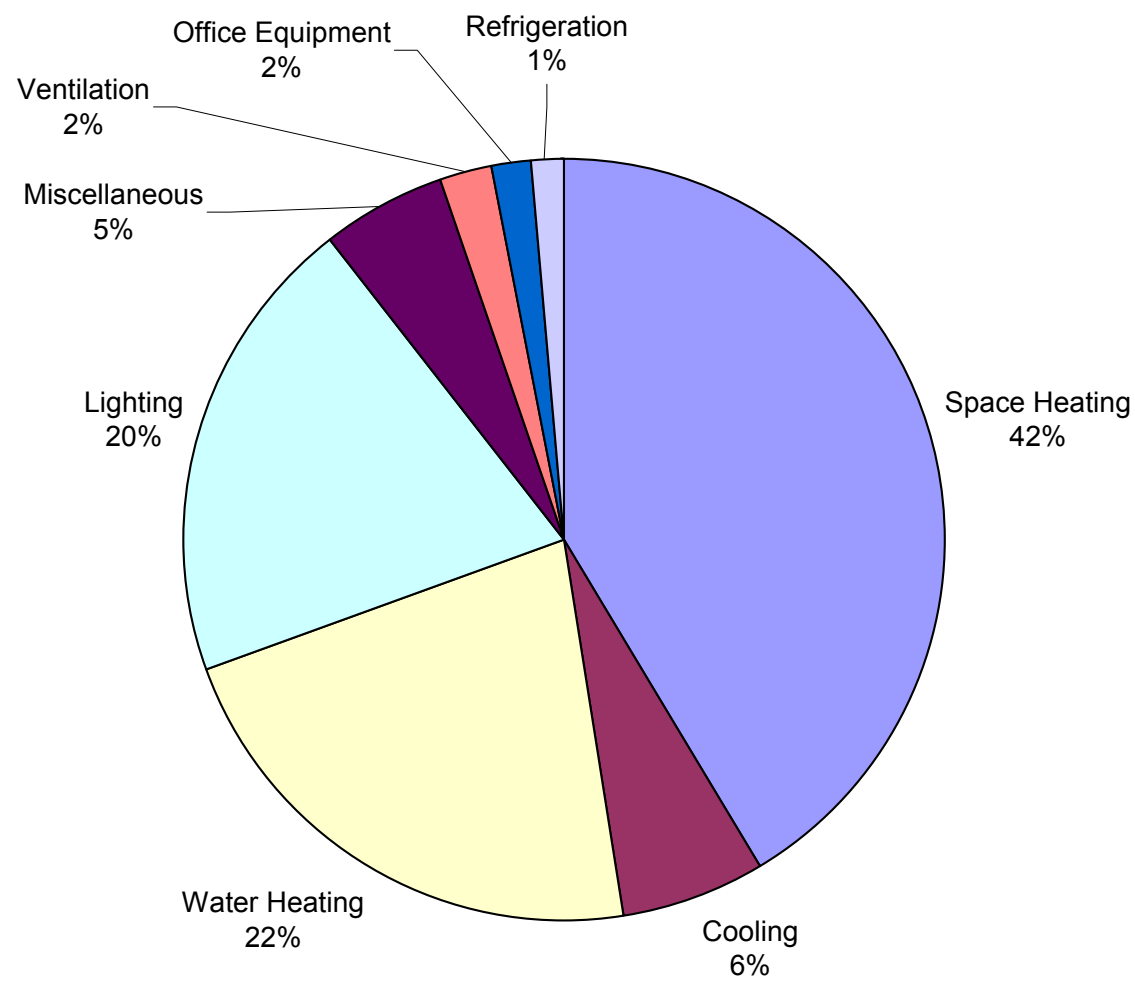

Figure 2-2 U.S. academic building site energy consumption by end use, 1995

Various categories from the CBECS database were then considered. Similar-sized educational buildings had an average energy intensity of $75.7 \mathrm{kBtu} / \mathrm{ft}^{2} \cdot \mathrm{yr}\left(860 \mathrm{MJ} / \mathrm{m}^{2} \cdot \mathrm{yr}\right)$ and recently constructed educational buildings had an average energy intensity of $74.1 \mathrm{kBtu} / \mathrm{ft}^{2} \cdot \mathrm{yr}\left(74.1 \mathrm{MJ} / \mathrm{m}^{2} \cdot \mathrm{yr}\right)$. Although the CBECS survey provided data for national and regional comparisons, a local comparison was also established. A campus-wide building energy consumption study, conducted at Oberlin College in 2001, revealed that the average site energy intensity of buildings at Oberlin College was $88.5 \mathrm{kBtu} / \mathrm{ft}^{2} \cdot \mathrm{yr}\left(1,010 \mathrm{MJ} / \mathrm{m}^{2} \cdot \mathrm{yr}\right)(\mathrm{RMI}$ 2001). As for individually measured buildings of similar size and type, the Vermont Law School's Oaks Hall building in South Royalton, Vermont was used. Law school staff had set aggressive design goals for the building: they wanted to create an educational facility that was not only healthy, comfortable, and durable, but one that efficiently used energy, water, materials, land, and capital. In addition, the primary use, size, and age of the building were similar to the Lewis Center as well as the area's climate. The published site energy intensity for Oaks Hall is $36.7 \mathrm{kBtu} / \mathrm{ft}^{2} \cdot \mathrm{yr}\left(417 \mathrm{MJ} / \mathrm{m}^{2} \cdot \mathrm{yr}\right)$ (Vermont Law School $2002)$, at $65.5 \mathrm{kBtu} / \mathrm{ft}^{2} \cdot \mathrm{yr}\left(745 \mathrm{MJ} / \mathrm{m}^{2} \cdot \mathrm{yr}\right)$ of source, or primary energy intensity consumption.

\subsection{First Year Energy Performance - Lewis Center}

Although the Lewis Center's first year of operation was not studied in detail by NREL, others at Oberlin College have documented the energy performance based on utility bills from the first year of occupancy and the first year of PV production (Scofield 2002, Scofield and Kaufman, 2002). Figure 2-3 shows monthly energy use and production, from the utility bills, for the first year of occupancy (Scofield 2002). The local utility company installed a meter to measure the electricity supplied to the Lewis Center and a meter to measure the PV production. The utility meters were not bi-directional, limiting the ability for a net metering agreement. Due to the arrangement of the utility meters, the Lewis Center did not receive credit for any PV production exported to the utility grid during the first year. The site energy consumption intensity of the Lewis Center was $47.5 \mathrm{kBtu} / \mathrm{ft}^{2} \cdot \mathrm{yr}\left(539 \mathrm{MJ} / \mathrm{m}^{2} \cdot \mathrm{yr}\right)$ during the first year of occupancy. The PV system was installed near the end of the first year. The total production by the end of 
the first year was $1.6 \mathrm{kBtu} / \mathrm{ft}^{2} \cdot \mathrm{yr}\left(18 \mathrm{MJ} / \mathrm{m}^{2} \cdot \mathrm{yr}\right)$. The net use translated to a source energy consumption intensity of $148.1 \mathrm{kBtu} / \mathrm{ft}^{2} \cdot \mathrm{yr}\left(1682 \mathrm{MJ} / \mathrm{m}^{2} \cdot \mathrm{yr}\right)$, which was considerably greater than the documented performance of the comparable Oaks Hall. The energy cost intensity for the first year was $\$ 1.21 / \mathrm{ft}^{2}$ $\left(\$ 13.02 / \mathrm{m}^{2}\right)$, also greater than $\$ 0.80 / \mathrm{ft}^{2}\left(\$ 8.61 / \mathrm{m}^{2}\right)$ average Midwest CBECS educational buildings. After examining the utility bills from the first year of occupancy, it was evident the Lewis Center was not performing as the designers had expected and more detailed analysis was necessary to identify and improve inefficient systems and operations. NREL and Oberlin College then monitored the building for an additional two years, the results of which are discussed in detail in Section 5.

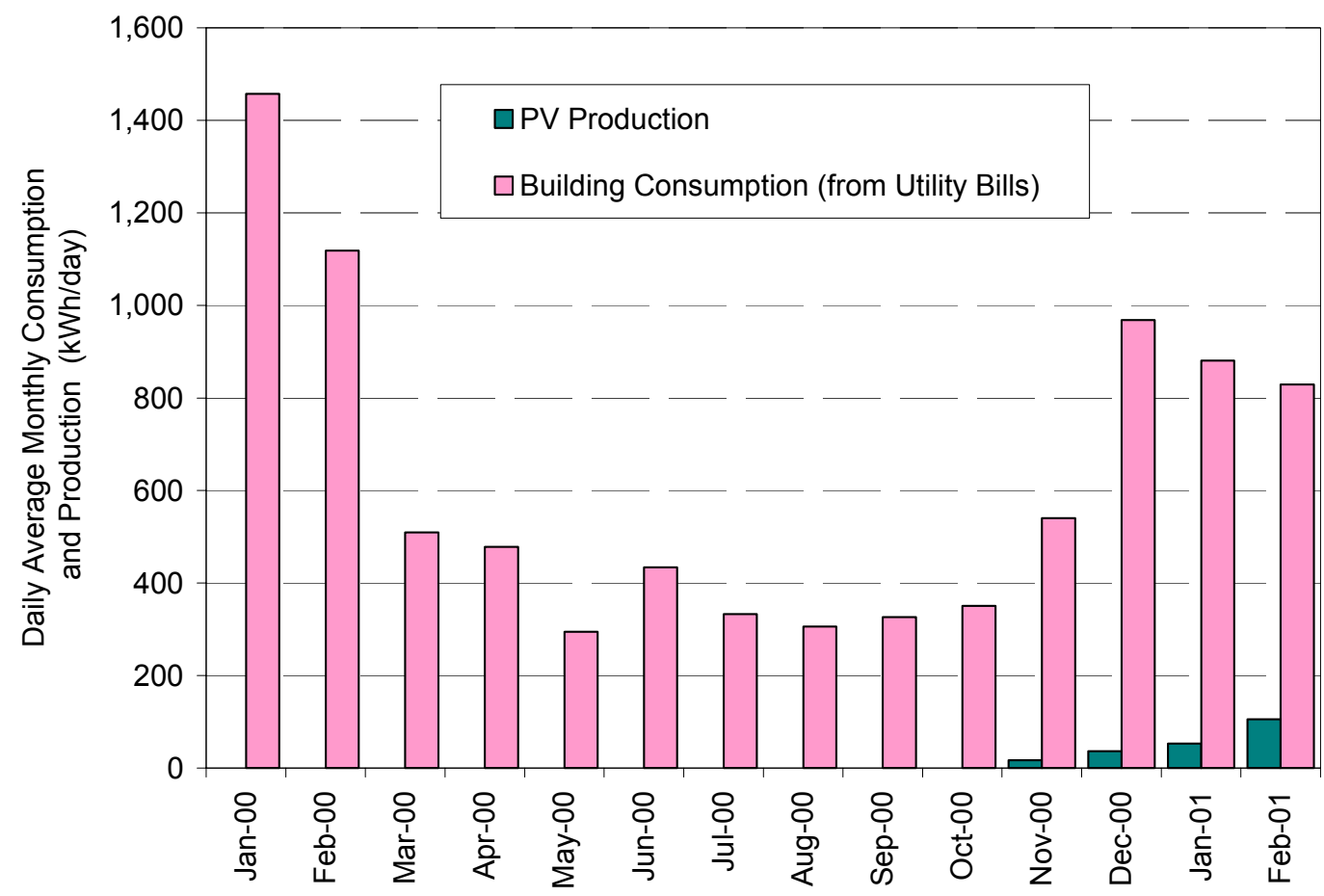

Figure 2-3 Lewis Center daily average site energy consumption and production, January 2000 through February 2001 


\section{Design Process}

The design process of the Lewis Center was led by the architecture firm William McDonough + Partners and professor David Orr of Oberlin's Environmental Studies Program. This process, which is described in detail at the Lewis Center website (Oberlin College 2003), started in 1996 with an initial proposal from Oberlin College students and Professor Orr. With student, faculty, and Oberlin community input and ideas, design goals were developed. The Environmental Studies Program then assembled a consulting team to refine these goals and design the Lewis Center. The design team included:

- Lev Zetlin Associates: Structural, mechanical, electrical and plumbing engineers

- William McDonough + Partners: Architects/engineers

- Steven Winter Associates: Energy analysis

- Andropogon Associates, Inc.: Landscape architects

- CT Consultants, Inc.: Civil engineer

- Heller Metzger, PC, Barbara Heller: Specifications

- Shen Milsom \& Wilke, Inc.: Acoustical/audio-visual consultants

- Hal Levin \& Associates: Indoor air quality consultant

- Living Technologies, Inc.: wastewater treatment system designers, now Living Machines, Inc.,

- Loisos/Ubbelohde: Daylighting

- Clanton \& Associates: Lighting

- Rocky Mountain Institute: Green development services

- Mosser Construction: General contractor

- Interface: Product-of-service carpeting

Specific design goals that guided the creation of the Lewis Center are included in Appendix A: Design Goals and Objectives. The design process was not explicitly studied as part of this technical report, as NREL was not involved in the design of the Lewis Center. 


\section{Lewis Center Building Description}

The Lewis Center is a two-story, $13,600-\mathrm{ft}^{2}\left(1,260-\mathrm{m}^{2}\right)$ building with classrooms, offices, an auditorium, an atrium, and an on-site wastewater treatment system used by the students in the Environmental Studies Program. The design team incorporated numerous energy saving design characteristics into the building.

A prominent feature of the building is a roof-integrated, $60-\mathrm{kW}$ photovoltaic (PV) system that produces electricity on-site (Number 1 in Figure 4-1). The system, which covers the entire roof, is connected to the local utility grid and does not have a battery backup system. The PV system exports power to the utility grid when the PV system produces more power than the building is currently using. Likewise, the building imports electricity from the utility when the PV system cannot meet the load. Electricity meets all energy needs, including mechanical systems and domestic hot water. This all-electric system was a requirement in order to meet the future net energy producing vision for the building. Using nonrenewable energy on-site could not have been recovered by the PV system.

Additional energy-efficient design measures incorporated into the Lewis Center consist of passive solar heating and ventilation, daylighting and efficient lighting designs, ground source heat pump loops, energy recovery from exhaust air, and an energy management system for controlling these systems

(NREL 2004). An ecologically engineered on-site wastewater treatment system, called a Living Machine ${ }^{\circledR}$ by the manufacturer, was designed to be an educational tool and research laboratory (Number 4 in Figure 4-1). This on-site wastewater treatment system combines conventional wastewater treatment technology with the purification processes of a natural wetland ecosystem to remove organic wastes and nutrients from wastewater.

The Lewis Center's design process began in 1996 and was led by the architecture firm William McDonough + Partners and Environmental Studies' professor David Orr. Construction began in September 1998, and the building was ready for occupancy in January 2000. The goals that guided the design are included in Appendix A. The building features described in this section are based on the mechanical, lighting, PV, and equipment systems present at the beginning of this evaluation, March 2001.

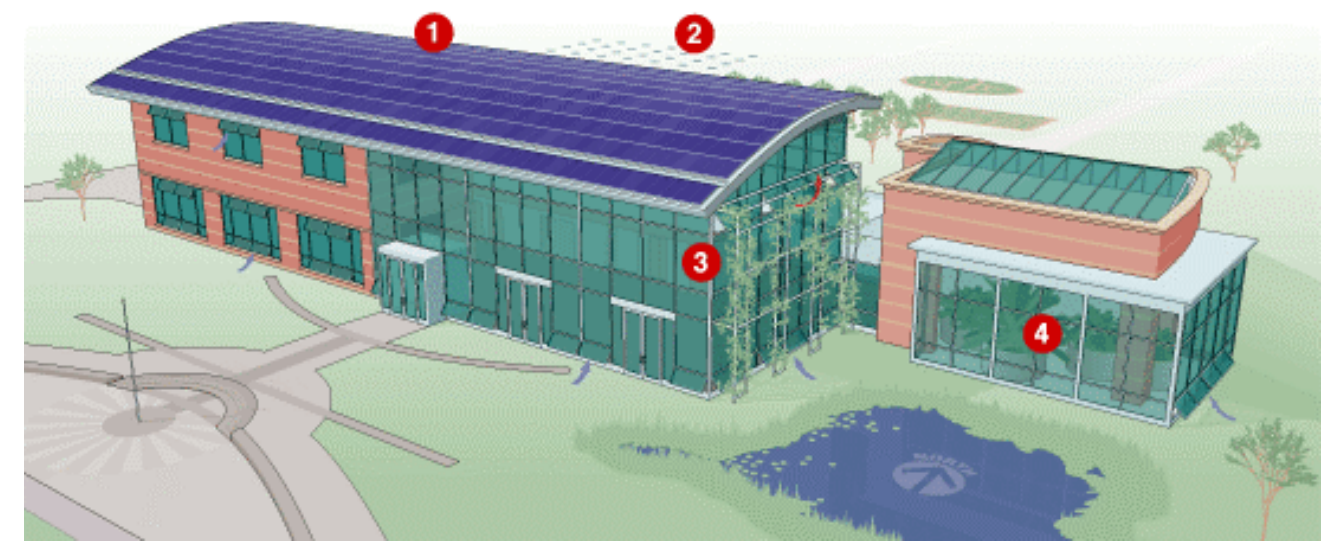

$1=\mathrm{PV}$ array

$2=$ Location of ground wells for heat pump loop

$3=$ Passive solar heating and ventilation; daylighting

4 = Sunspace for ecological wastewater system

Figure 4-1 Significant high-performance building technology features (NREL 2004) 


\subsection{Building Envelope}

The design team orientated the building to face south and elongated the east-west axis to maximize solar heat gain and to improve the efficiency of the passive solar features and PV system. The building orientation, combined with engineered window overhangs and fenestration, contributes to the solar heat gain in the winter, solar load avoidance in the summer, and the increased use of natural light. Thermal mass is integrated into the design with exposed masonry in the atrium floors. The thermal mass stores heat from the sun in the winter and moderates summer temperatures to reduce peak loads on the building.

The layout of the spaces was also designed with the orientation in mind. Figure 4-2 and Figure 4-3 illustrate this layout. High use areas, including the atrium and classrooms, are located on the south side of the building so that natural light can contribute to lighting needs and reduce lighting loads. Equipment rooms and the kitchen are located on the north side of the building. The sunspace, used for the on-site wastewater treatment system, required solar access and is located on the south side. The auditorium, programmed not to use daylighting because of presentation requirements, is located on the north side. The resulting footprint is $140 \mathrm{ft}$ by $45 \mathrm{ft}$ ( $43 \mathrm{~m}$ by $14 \mathrm{~m}$ ) with an attached 100 -seat auditorium and sunspace. 


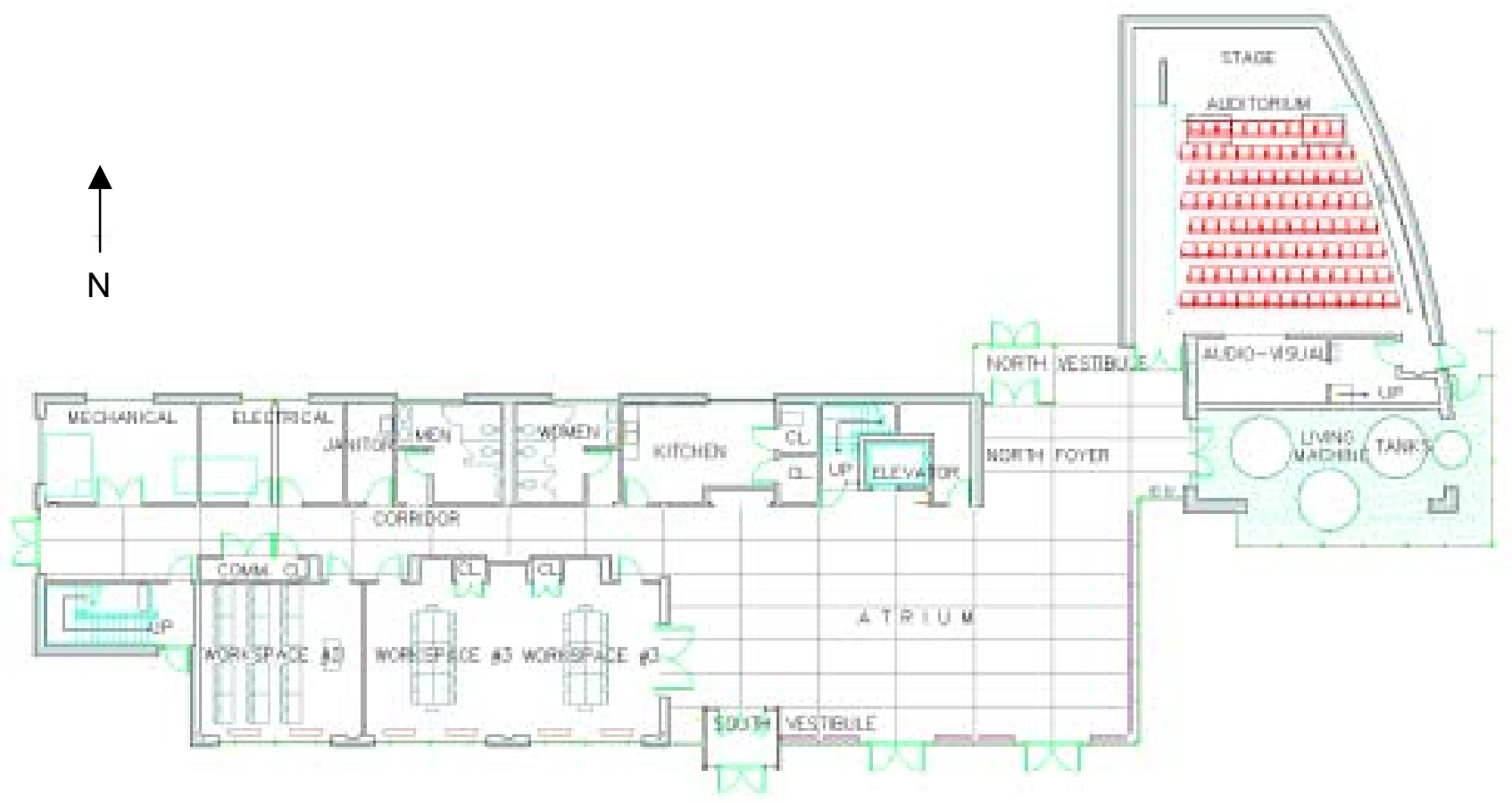

Figure 4-2 First-floor plan

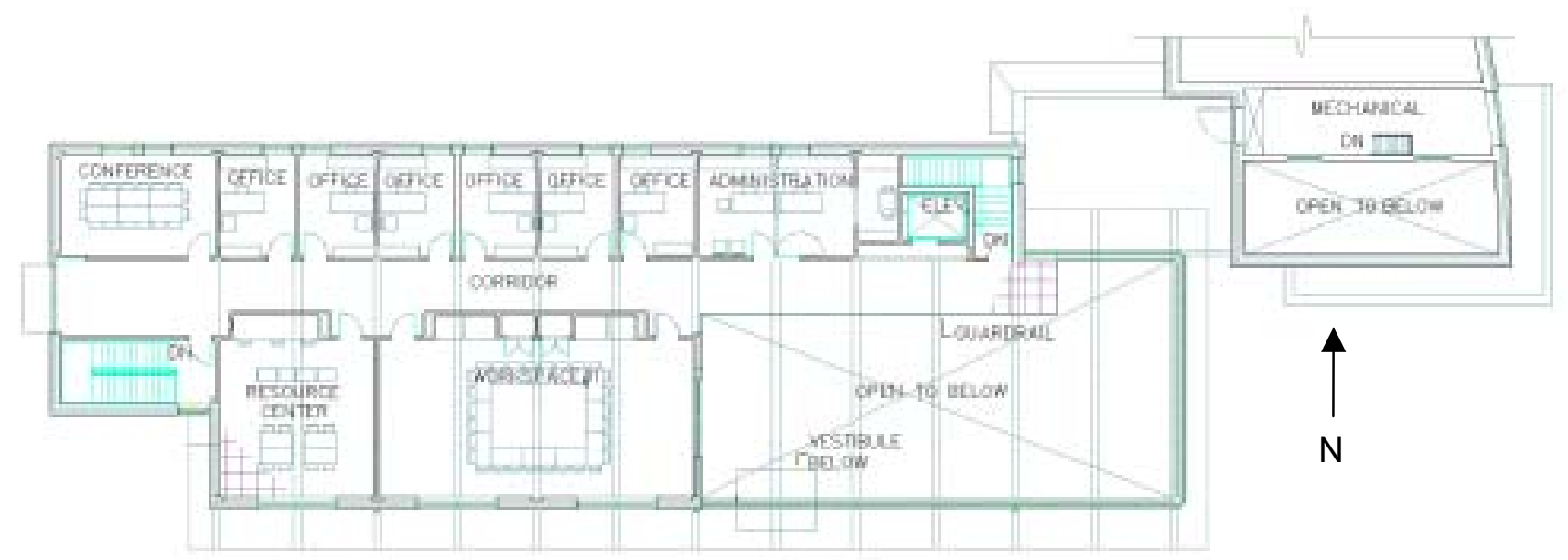

Figure 4-3 Second-floor plan

Insulation values for the envelope include R-19 exterior walls and R-30 for the ceiling and roof. The atrium curtain wall includes tinted, argon-filled, low-e, triple-pane glass with thermally broken aluminum frames for the north, east, and south exterior wall surfaces. All other windows are double pane, low-e, argon-filled windows with thermally broken aluminum frames. The 6-in. (15-cm) entire concrete slab in the atrium is insulated with 2-in. (5-cm) R-10 insulation. The perimeter footings are insulated with 4-in. $(10-\mathrm{cm}) \mathrm{R}-20$ polystyrene insulation. Table $4-1$ summarizes the envelope thermal properties. 
Table 4-1 Building Envelope Construction and Thermal Properties (ASHRAE 2001b)

\begin{tabular}{|c|c|c|c|}
\hline Envelope Component & Construction (outside to inside) & $\begin{array}{c}R_{\text {effective }} \\
\left(\mathrm{hr} \cdot \mathrm{ft}^{2} \cdot{ }^{\circ} \mathrm{F} / \mathrm{Btu}\right)\end{array}$ & $\begin{array}{l}R_{\text {effective }} \\
\left(\mathrm{m}^{2} \cdot \mathrm{K} / \mathrm{W}\right)\end{array}$ \\
\hline \multicolumn{4}{|l|}{ Walls } \\
\hline $\begin{array}{l}\text { North side } \\
\text { underground } \\
\text { exterior wall }\end{array}$ & $\begin{array}{l}\text { 2-in. rigid polystyrene insulation, } \\
\text { 16-in. concrete masonry unit (CMU) }\end{array}$ & 12.0 & 2.1 \\
\hline Auditorium walls & $\begin{array}{l}\text { 4-in. face brick, } 1 \text {-in. air cavity, 3-in. } \\
\text { polystyrene insulation, } 12 \text {-in. CMU }\end{array}$ & 20.0 & 3.5 \\
\hline $\begin{array}{l}\text { All other brick faced } \\
\text { exterior walls }\end{array}$ & $\begin{array}{l}\text { 4-in. face brick, } 1 \text {-in. air cavity, 3-in. } \\
\text { polystyrene insulation, } 8 \text {-in. CMU }\end{array}$ & 19.0 & 3.3 \\
\hline \multicolumn{4}{|l|}{ Windows/doors } \\
\hline $\begin{array}{l}\text { Atrium glass curtain } \\
\text { walls }\end{array}$ & $\begin{array}{l}\text { Triple-pane, argon-filled, tinted } \\
\text { insulating glass with thermally } \\
\text { broken aluminum frames }\end{array}$ & 2.9 & 0.5 \\
\hline $\begin{array}{l}\text { Insulating windows } \\
\text { (nonatrium glass) }\end{array}$ & $\begin{array}{l}\text { Double-pane, argon-filled, tinted } \\
\text { insulating glass with thermally } \\
\text { broken aluminum frames }\end{array}$ & 2.2 & 0.4 \\
\hline \multicolumn{4}{|l|}{ Roofs } \\
\hline $\begin{array}{l}\text { Curved roof sections } \\
\text { (upper roof and } \\
\text { auditorium) }\end{array}$ & $\begin{array}{l}\text { Standing seam steel, felt paper, } \\
\text { sheathing, 1-in. air gap, 5-in. rigid } \\
\text { polystyrene, wood decking }\end{array}$ & 27.0 & 4.8 \\
\hline Flat roofs (small slope) & $\begin{array}{l}\text { Stone ballast, 4- to } 8 \text {-in. extruded } \\
\text { polystyrene, 4-in. concrete with } \\
\text { cellular metal decking }\end{array}$ & $20.5-40.5^{1}$ & $3.6-7.1$ \\
\hline \multicolumn{4}{|l|}{ Floors } \\
\hline All perimeter footings & $\begin{array}{l}\text { 2-in. rigid insulation, } 16 \text {-in. concrete } \\
\text { footing, } 2 \text {-in. rigid insulation }\end{array}$ & 21.6 & 3.8 \\
\hline Atrium slab & $\begin{array}{l}\text { 2-in. rigid insulation, } 10 \text {-in. } \\
\text { structural and topping slab, 3/4-in. } \\
\text { slate }\end{array}$ & 11.5 & 2.0 \\
\hline Nonatrium slab & $\begin{array}{l}\text { 2-in. rigid insulation, 6-in. structural } \\
\text { slab }\end{array}$ & 11.0 & 1.9 \\
\hline First-floor classrooms & $\begin{array}{l}\text { 2-in. rigid insulation, 6-in. structural } \\
\text { slab, 12-in. raised floor air gap, } \\
\text { decking, carpet }\end{array}$ & 12.0 & 2.1 \\
\hline
\end{tabular}

Notes:

1. R-value ranges are due to variation in insulation thickness 


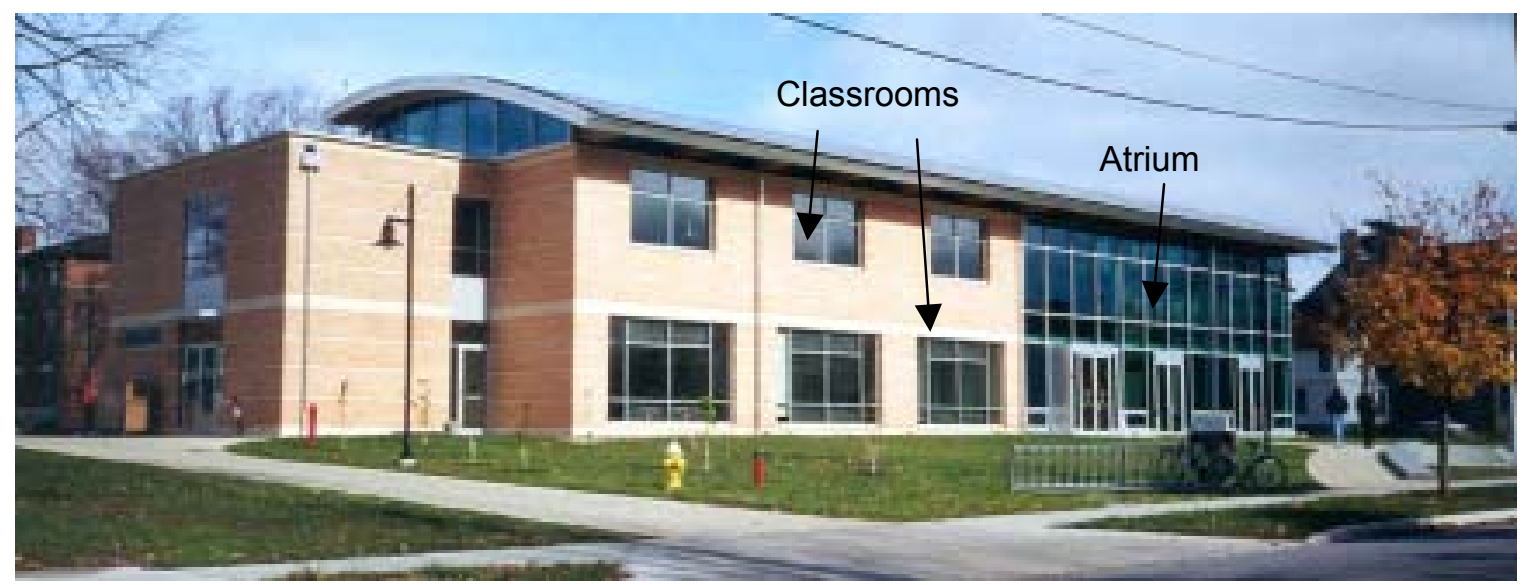

Figure 4-4 South façade of the Lewis Center

Figure 4-4 shows the location of the southern fenestration, including the $2.5-\mathrm{ft}(0.76-\mathrm{m})$ window overhangs of the curved roof designed to block the high summer sun and the clerestory windows on the upper western side of the building designed to optimize daylighting. The south- and east-facing fenestration in the atrium is green tinted glass with a visible transmittance of $46 \%$ and a solar heat gain coefficient (SHGC) of 0.26 (shading coefficient of 0.30 ). The rest of the building glass is gray tinted insulating glass with a visible transmittance of $69 \%$ and a SHGC of 0.46 (shading coefficient of 0.53 ). Figure 4-5 shows the northern clerestory windows and second-floor office windows.

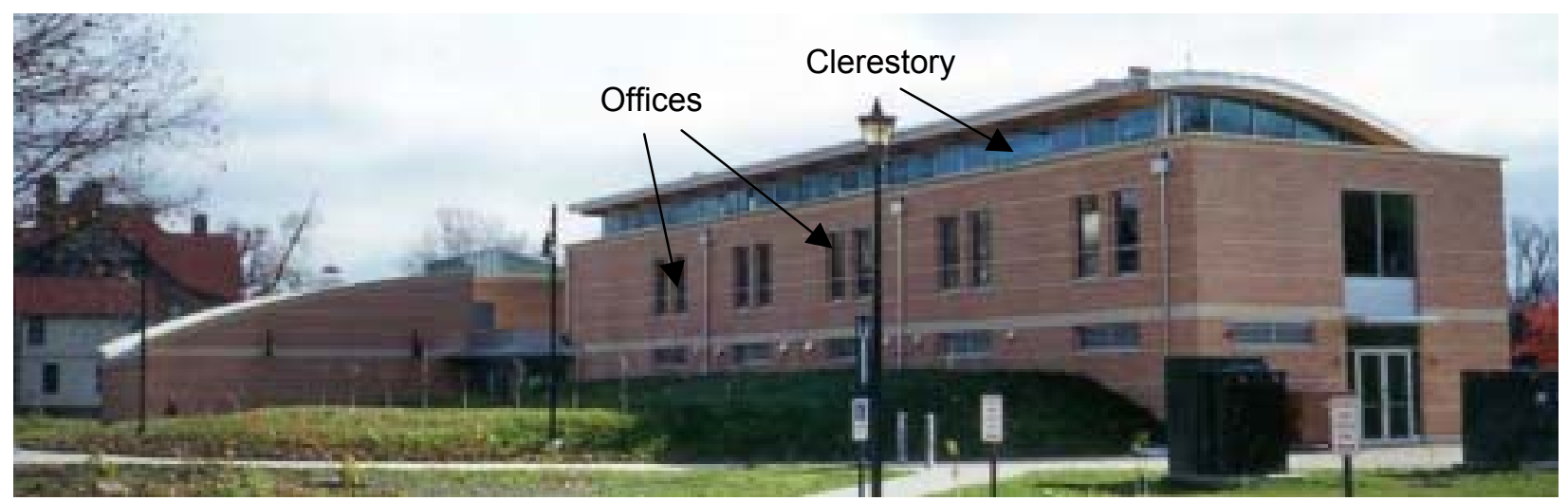

Figure 4-5 North façade

Figure 4-6 shows the atrium from the second floor corridor looking east. For shading purposes, the occupants can lower the motorized shades over the eastern atrium glass. 


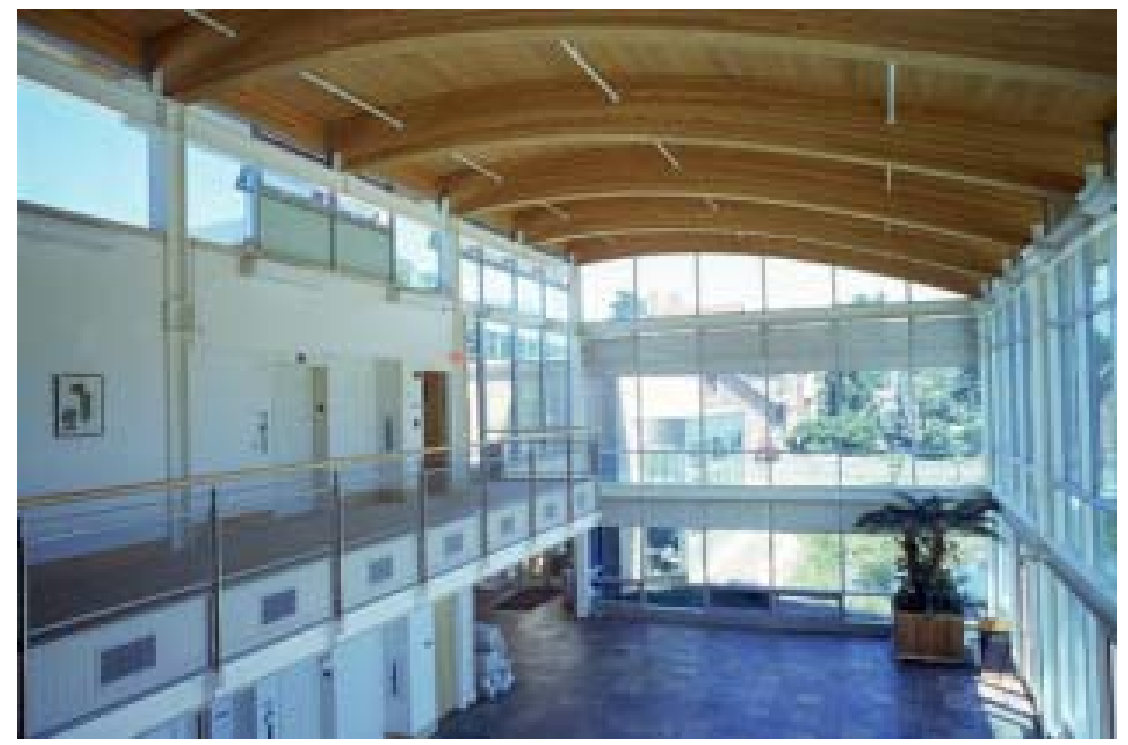

Figure 4-6 Interior atrium from second floor looking east

Table 4-2 summarizes the window-to-wall ratio for the four primary facades of the building. The high window-to-wall ratio of the east and north façade is due to the glass curtain wall in the atrium. The overall fenestration ratio is $43 \%$ of total wall area.

Table 4-2 Building Fenestration

\begin{tabular}{|c|r|r|r|c|c|}
\hline Wall Location & \multicolumn{2}{|c|}{ Fenestration Area } & \multicolumn{2}{|c|}{ Total Wall Area } & $\begin{array}{c}\text { Fenestration to Total } \\
\text { Wall Area Ratio }\end{array}$ \\
\hline \hline North & $1,675 \mathrm{ft}^{2}$ & $156 \mathrm{~m}^{2}$ & $4,372 \mathrm{ft}^{2}$ & $406 \mathrm{~m}^{2}$ & 0.38 \\
\hline South & $2,553 \mathrm{ft}^{2}$ & $235 \mathrm{~m}^{2}$ & $4,498 \mathrm{ft}^{2}$ & $418 \mathrm{~m}^{2}$ & 0.57 \\
\hline East & $1,084 \mathrm{ft}^{2}$ & $101 \mathrm{~m}^{2}$ & $2,371 \mathrm{ft}^{2}$ & $220 \mathrm{~m}^{2}$ & 0.46 \\
\hline West & $350 \mathrm{ft}^{2}$ & $33 \mathrm{~m}^{2}$ & $2,512 \mathrm{ft}^{2}$ & $233 \mathrm{~m}^{2}$ & 0.14 \\
\hline All & $\mathbf{6 , 0 6 3 \mathrm { ft } ^ { 2 }}$ & $\mathbf{5 6 3 \mathrm { m } ^ { 2 }}$ & $\mathbf{1 4 , 1 5 3 \mathrm { ft } ^ { 2 }}$ & $\mathbf{1 3 1 5 \mathrm { m } ^ { 2 }}$ & $\mathbf{0 . 4 3}$ \\
\hline
\end{tabular}

All of the smaller windows in the classrooms and offices can be opened manually. The small lower windows in the south and east atrium walls, along with the upper north clerestory windows, are controlled by the building's energy management system (EMS). The windows are designed to create a stack effect through the atrium, supplying natural ventilation when outdoor conditions permit.

\subsection{Lighting and Daylighting}

The indoor lighting zones include mechanical rooms, bathrooms, kitchen, corridor zones, classrooms, offices, atrium, and auditorium. Figure 4-7 and Figure 4-8 show the type and location of each luminaire. Table 4-3 describes each luminaire; lighting controls are described in Table 4-4. The highly occupied classroom lighting zones are located on the south side of the building to maximize the daylighting potential. The minimally occupied spaces, such as the mechanical rooms, are located on the north side of the building partially below grade. A north-facing clerestory allows diffuse daylight to assist in illuminating the second-floor corridor, north-facing offices, and south-facing classrooms. The auditorium has no windows or clerestory, as defined by the original program for the building. 


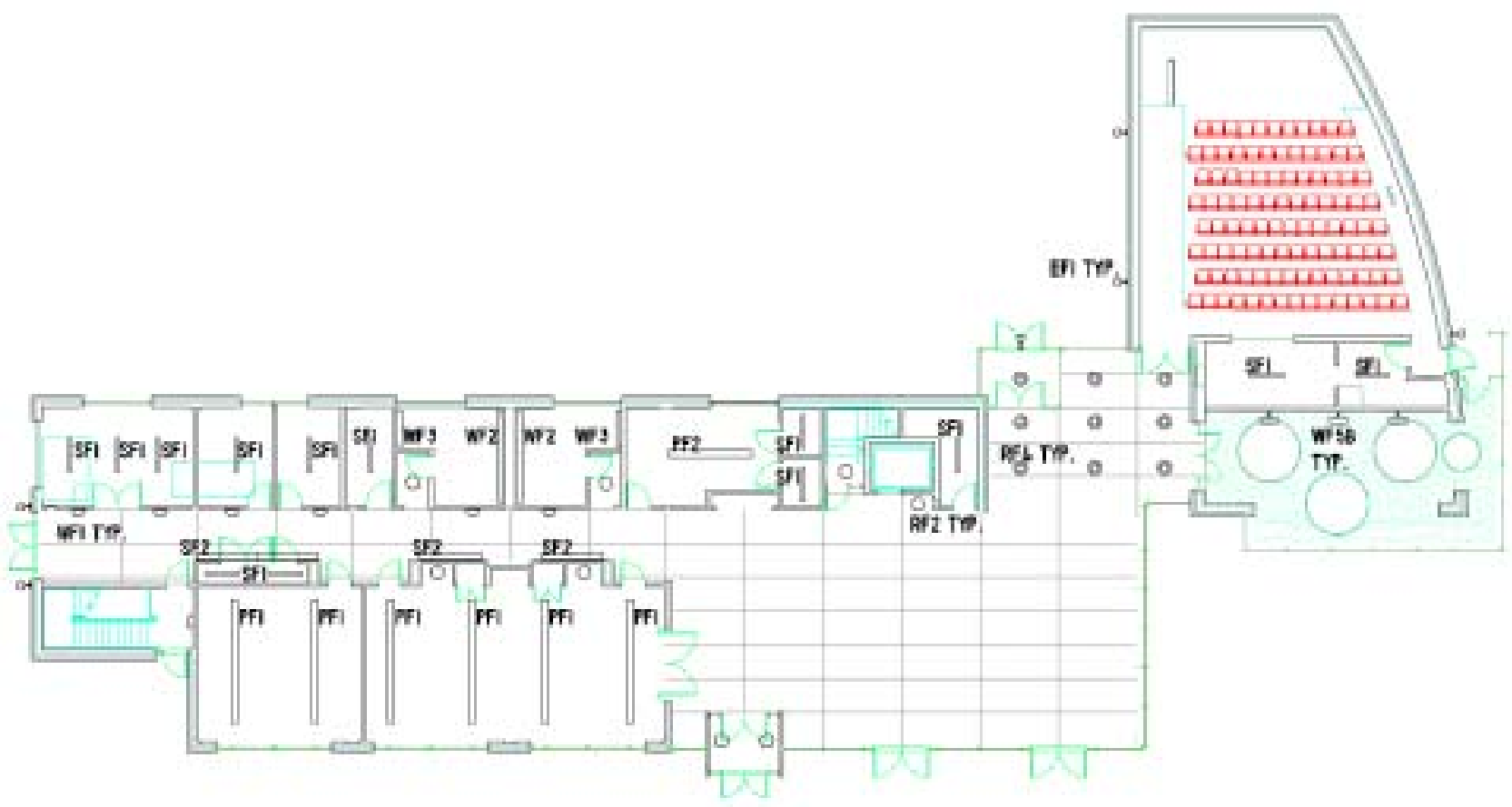

Figure 4-7 First-floor lighting plan

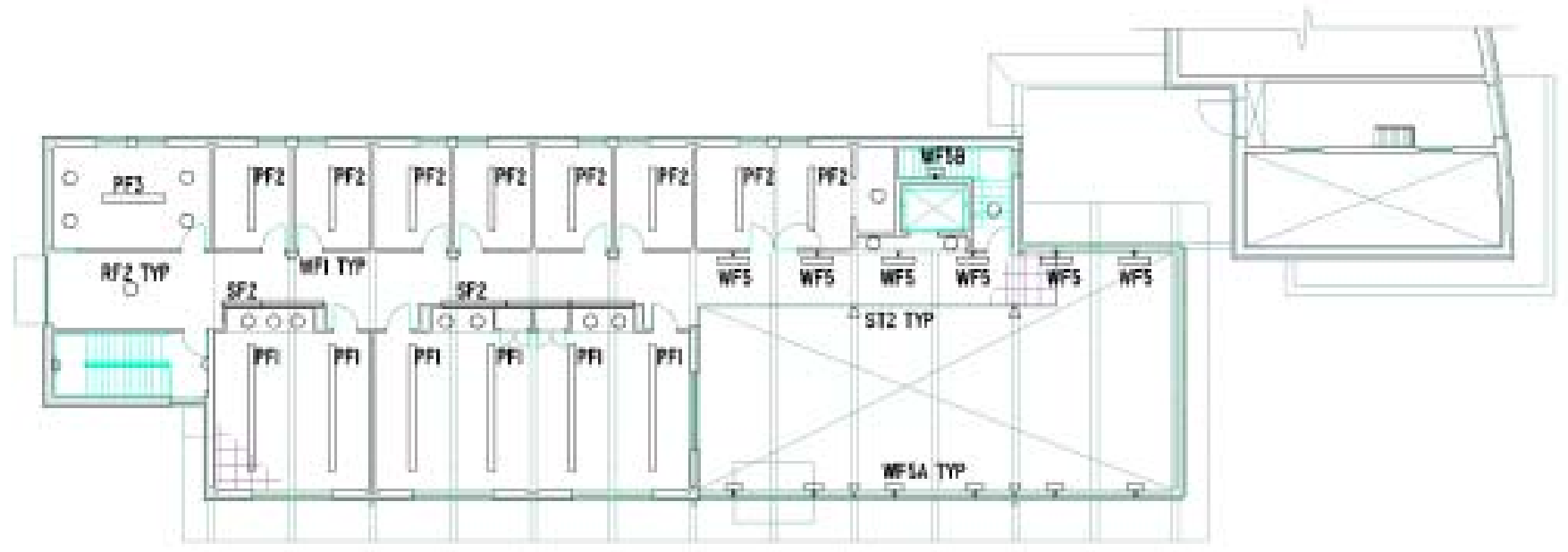

Figure 4-8 Second-floor lighting plan

The electrical lighting systems include efficient lamps and fixtures, dimmers, and sensors to provide automatic and occupancy control of lighting levels. The classrooms, offices, restrooms, and corridors have motion sensors that turn lights on when the spaces are occupied. The hallway and classroom lights are also connected to photo sensors, which override the occupancy sensors when enough daylighting is available. 
Table 4-3 Luminaire Schedule

\begin{tabular}{|c|l|r|c|}
\hline Type & \multicolumn{1}{|c|}{ Description } & $\begin{array}{c}\text { Lamp } \\
\text { Watts }\end{array}$ & $\begin{array}{c}\text { Total Fixture } \\
\text { Watts }\end{array}$ \\
\hline \hline EF1 & Exterior wall-mounted compact fluorescent area light & 17 & 85 \\
\hline PF1 & Indirect/direct linear fluorescent pendent 2-lamp T8 profile & 256 & 3,072 \\
\hline PF2 & Indirect/direct linear fluorescent pendent 2-lamp T8 profile & 140 & 1,260 \\
\hline PF3 & Indirect/direct linear fluorescent pendent 2-lamp T8 profile & 134 & 134 \\
\hline RF2 & Ceiling-mounted recessed compact fluorescent area light & 28 & 616 \\
\hline RF4 & Ceiling-mounted recessed compact fluorescent area light & 39 & 351 \\
\hline SF1 & 3-in. industrial fluorescent 1-lamp strip & 25 & 325 \\
\hline SF2 & Surface-mounted 1-lamp concealed fluorescent cove light & 64 & 544 \\
\hline ST2 & Wall-mounted incandescent halogen spotlight & 90 & 360 \\
\hline WF1 & Wall-mounted compact fluorescent wall sconce & 41 & 492 \\
\hline WF2 & Wall-mounted 1-lamp linear fluorescent & 96 & 192 \\
\hline WF3 & Wall-mounted sconce modified to accept (1) 32-W T8 fluorescent & 32 & 64 \\
\hline WF5 & Wall-mounted 2-lamp 50-in. long compact fluorescent up light & 146 & 876 \\
\hline WF5A & Wall-mounted 2-lamp 27-in. long compact fluorescent up light & 73 & 438 \\
\hline WF5B & Wall-mounted 2-lamp 27-in. long compact fluorescent & 71 & 284 \\
\hline
\end{tabular}

The auditorium zone contains multiple types of area fluorescents and incandescent halogen spotlights for an installed lighting load of $1.64 \mathrm{~kW}\left(1.15 \mathrm{~W} / \mathrm{ft}^{2}\right.$ or $\left.12.4 \mathrm{~W} / \mathrm{m}^{2}\right)$. The installed lighting power density (LPD) is $1.26 \mathrm{~W} / \mathrm{ft}^{2}\left(13.6 \mathrm{~W} / \mathrm{m}^{2}\right)$ in the classrooms and resource center, $0.88 \mathrm{~W} / \mathrm{ft}^{2}\left(9.5 \mathrm{~W} / \mathrm{m}^{2}\right)$ in the offices, $0.93 \mathrm{~W} / \mathrm{ft}^{2}\left(10 \mathrm{~W} / \mathrm{m}^{2}\right)$ in the atrium, and $0.45 \mathrm{~W} / \mathrm{ft}^{2}\left(4.8 \mathrm{~W} / \mathrm{m}^{2}\right)$ in the corridors, sunspace, and transition spaces. The installed LPD for the building is $0.79 \mathrm{~W} / \mathrm{ft}^{2}\left(8.5 \mathrm{~W} / \mathrm{m}^{2}\right)$, which includes exterior lights mounted to the building, but not the parking lot and sidewalk lights. The total installed LPD for the site is $0.94 \mathrm{~W} / \mathrm{ft}^{2}\left(10 \mathrm{~W} / \mathrm{m}^{2}\right)$. This value includes $2.1 \mathrm{~kW}$ of parking lot and sidewalk lights that are connected to the building lighting panels.

Based on lighting zone and type, the lighting measurements were divided into categories as follows: auditorium lights, emergency lights, sidewalk lights, parking lot lights, and all indoor area lighting (excluding auditorium). Table 4-4 summarizes controls, fixtures, and end use measurement categories. The indoor area lighting category does not include any task lighting. 
Table 4-4 Lighting Zone Control with End use Measurement Category

\begin{tabular}{|c|c|c|}
\hline $\begin{array}{l}\text { Lighting Zone and Type } \\
\text { (see Figure 4-7 and Figure 4-8 } \\
\text { for lighting descriptions) }\end{array}$ & Control Strategy & $\begin{array}{l}\text { End use } \\
\text { Category }\end{array}$ \\
\hline Atrium: ST2, WF5 & Manual dimmer & $\begin{array}{l}\text { Indoor area } \\
\text { lights }\end{array}$ \\
\hline Atrium: WF5A, RF4 & Manual dimmer & $\begin{array}{l}\text { Emergency } \\
\text { lights }\end{array}$ \\
\hline Corridors: WF1, WF5B, RF2 & $\begin{array}{l}\text { Ceiling-mounted infrared occupancy sensor only } \\
\text { from March } 1,2001 \text { to June } 23,2001 \text {. } \\
\text { Ceiling-mounted infrared occupancy sensor with } \\
\text { minimum illuminance hold from June } 23,2001 \\
\text { through February } 28,2002 \text {. }\end{array}$ & $\begin{array}{l}\text { Emergency } \\
\text { lights }\end{array}$ \\
\hline Offices: PF2 & $\begin{array}{l}\text { Dimmable passive infrared wall switch/occupancy } \\
\text { sensor }\end{array}$ & $\begin{array}{l}\text { Indoor area } \\
\text { lights }\end{array}$ \\
\hline Classrooms: PF1, RF2 & $\begin{array}{l}\text { Occupancy sensor only from March } 1,2001 \text { to } \\
\text { January } 5,2002 \text {. Controlled on at } 50 \% \text { dimmed, } \\
\text { manual control from off }(0 \%) \text { to } 100 \% \text { power. } \\
\text { Dimmable passive infrared wall switch/occupancy } \\
\text { sensor with minimum illuminance hold from } \\
\text { January } 5,2002 \text { through February } 28,2002 \text {. } \\
\text { Controlled on at } 50 \% \text { dimmed, manual control for } \\
\text { off }(0 \%) \text { to } 100 \% \text { power. }\end{array}$ & $\begin{array}{l}\text { Indoor area } \\
\text { lights }\end{array}$ \\
\hline Auditorium & Manual continuous dimmer & Auditorium lights \\
\hline Conference room: RF2, PF3 & $\begin{array}{l}\text { Ceiling-mounted ultrasonic occupancy sensor with } \\
\text { manual continuous dimmer }\end{array}$ & $\begin{array}{l}\text { Indoor area } \\
\text { lights }\end{array}$ \\
\hline Building exterior: EF1 & Photocell & $\begin{array}{l}\text { Emergency } \\
\text { lights }\end{array}$ \\
\hline Parking lot and sidewalk & Photocell & $\begin{array}{l}\text { Parking lot and } \\
\text { sidewalk lights }\end{array}$ \\
\hline Wastewater treatment: WF5B & $\begin{array}{l}\text { Ceiling-mounted infrared occupancy sensor with } \\
\text { minimum illuminance hold }\end{array}$ & $\begin{array}{l}\text { Wastewater } \\
\text { treatment } \\
\text { equipment }\end{array}$ \\
\hline $\begin{array}{l}\text { Mechanical, electrical, storage: } \\
\text { SF1 }\end{array}$ & $\begin{array}{l}\text { Wall box occupancy sensor with manual } \\
\text { on/off/auto switch }\end{array}$ & $\begin{array}{l}\text { Indoor area } \\
\text { lights }\end{array}$ \\
\hline Bathrooms: WF2, WF3, RF2 & Ceiling-mounted ultrasonic occupancy sensor & $\begin{array}{l}\text { Indoor area } \\
\text { lights }\end{array}$ \\
\hline Kitchen: PF2, SF1 & Manual on/off switch & $\begin{array}{l}\text { Indoor area } \\
\text { lights }\end{array}$ \\
\hline
\end{tabular}

\subsection{PV System}

The PV system installed at the Lewis Center is a $60-\mathrm{kW}$, three-phase, grid-tied system with no battery storage. Mounted to the roof are 690, 85-watt single crystalline modules. The far northern set of PV panel strings in each array is tilted to the north at $3^{\circ}$ and the southernmost strings are at a $20^{\circ}$ tilt to the south. The building orientation allows for the tilted section of the PV array to face due south, as shown in Figure 4-9. 


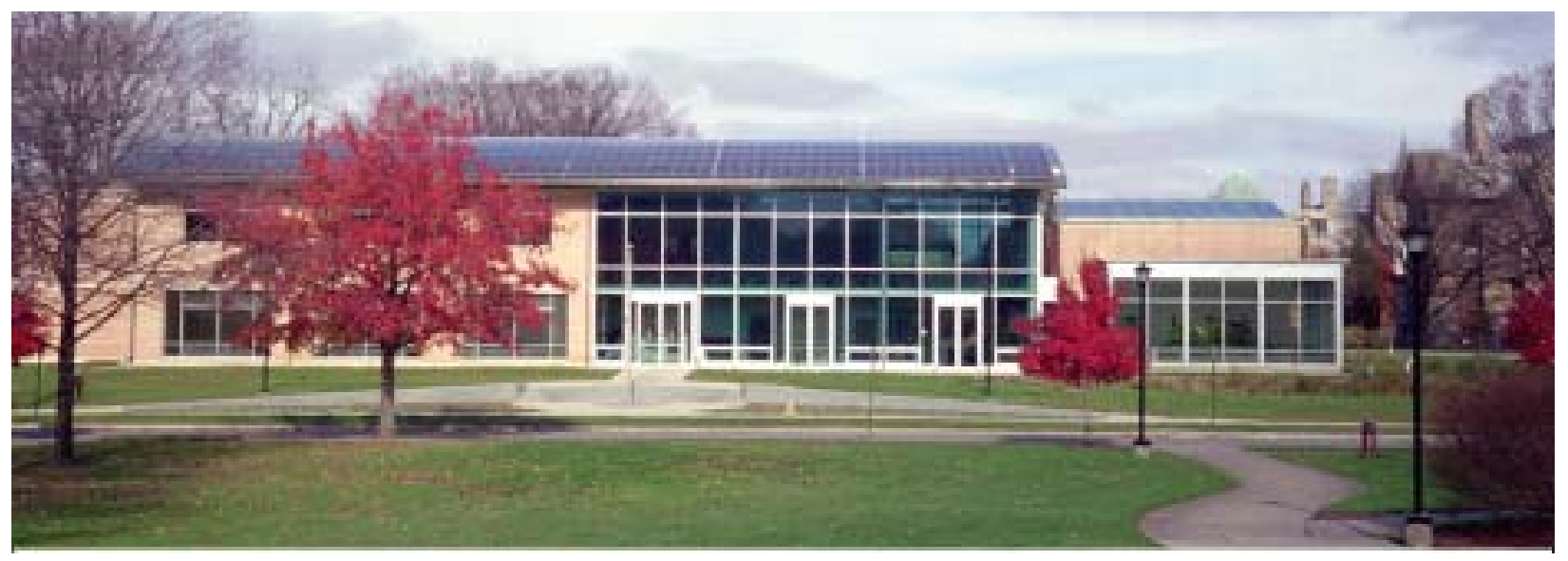

Figure 4-9 PV installation seen from south

The PV system is wired as three separate but identical subarrays. Subarray A represents the first onethird section of the total array on the west end of the building, subarray B the middle one-third, and subarray $\mathrm{C}$ the east one-third. Each subarray consists of 23 modules in series oriented east to west with 10 of these strings wired in parallel from north to south. Each subarray in this wiring configuration is rated at $19.54 \mathrm{~kW}$ (414 volts DC and 47.2 amps) at the peak output under standard test conditions. Figure 4-10 and Figure 4-11 show a roof plan view of the subarray configuration.

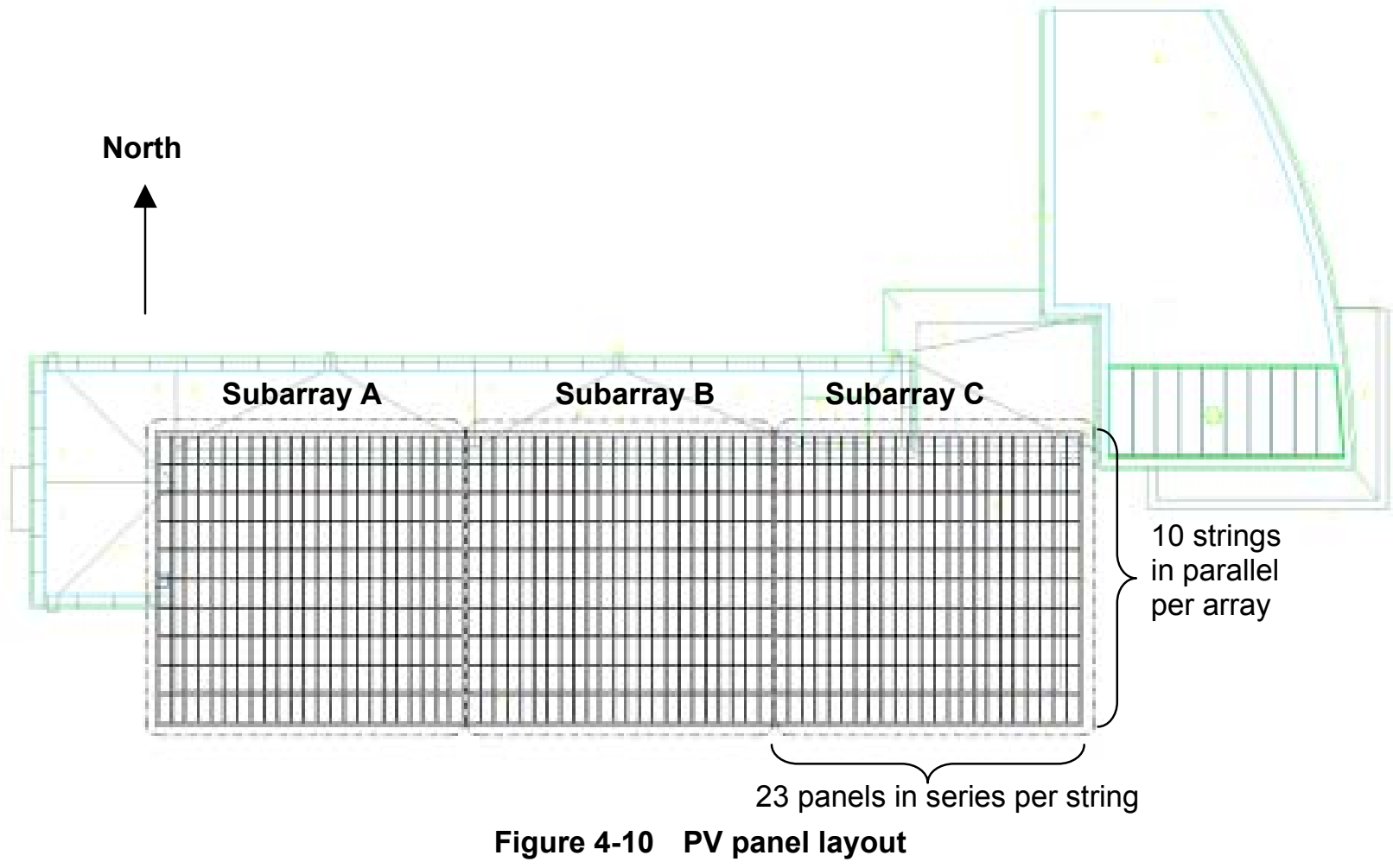




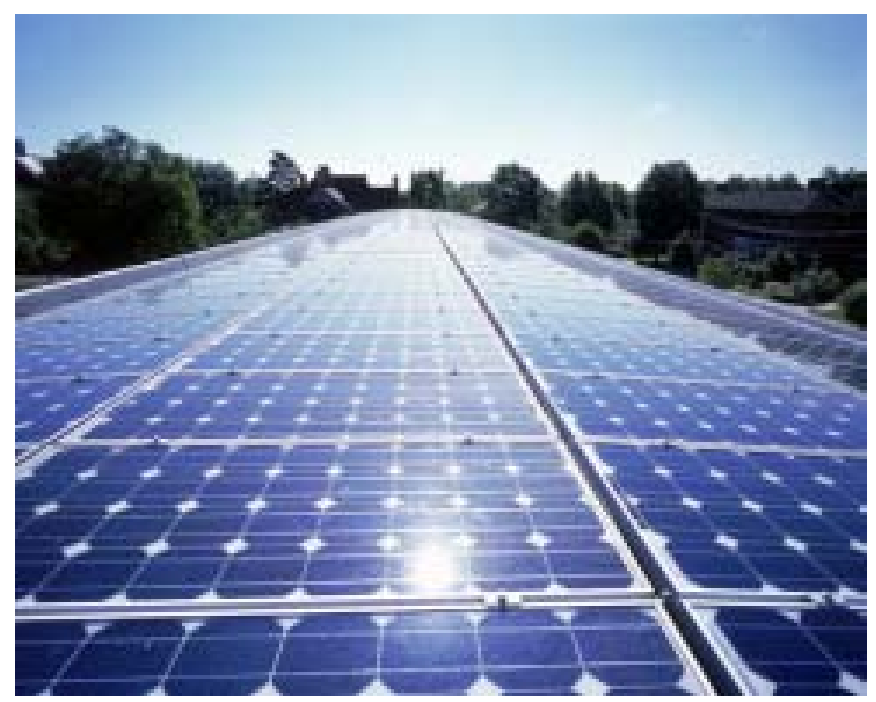

Figure 4-11 View of PV system from west end

Each subarray is connected to a three-phase, 15-kW grid-tied inverter, shown in the photo in Figure 4-12. Each inverter is connected to the building's main distribution panel through a 15-kVA-isolation transformer. Section 6.3 includes a one-line schematic of this PV system (Figure 6-11).

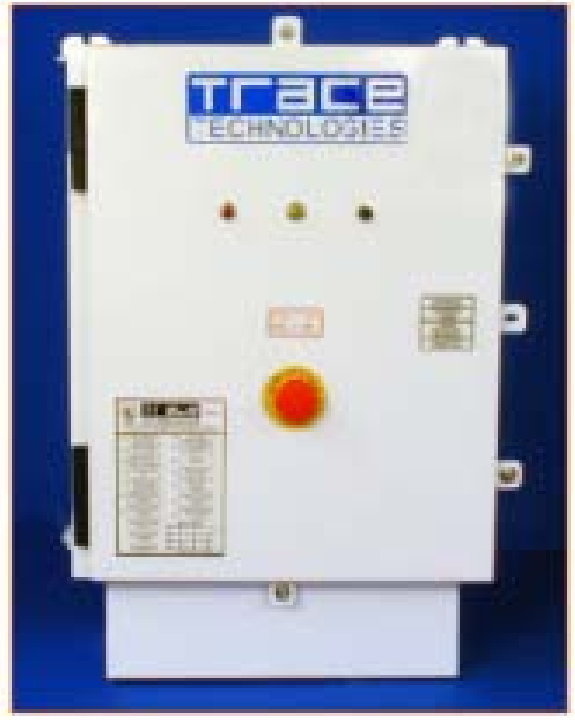

Figure 4-12 Fifteen-kilowatt grid-tied inverter

\subsection{Mechanical Systems}

The primary intent of the heating, ventilating, and air-conditioning (HVAC) design was to decouple ventilation from the heating and cooling systems. As a result, the heating and cooling systems were decentralized by zone. To accomplish this, individual room heat pumps were used for the individual classrooms and offices. Figure 4-13 shows a schematic of a typical console heat pump at the Lewis Center. The descriptions provided in this section represent the equipment and operation in March 2001, at the beginning of the performance evaluation. 


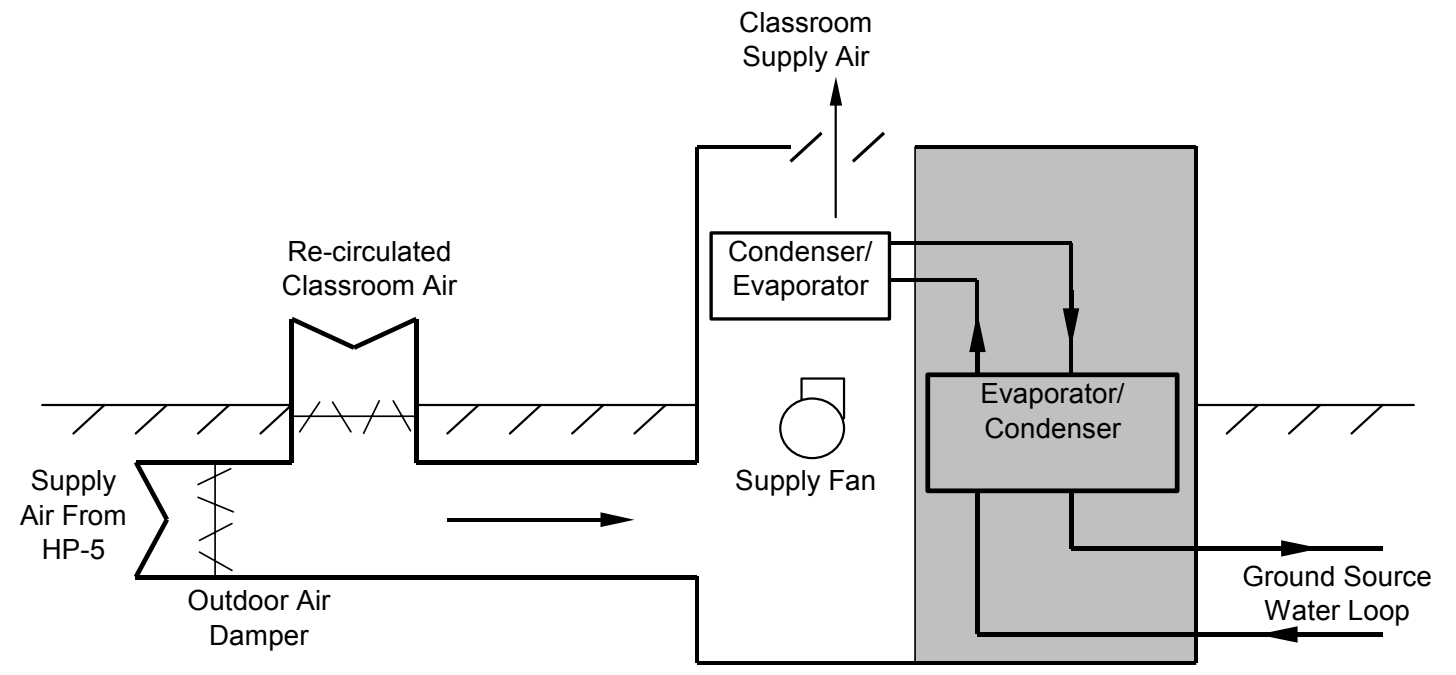

Figure 4-13 Schematic of the console heat pumps and how they operate

In the classrooms and the conference room, ventilation air is controlled through an outdoor air damper, which is opened to $50 \%$ when occupancy sensors detect motion. While there are $\mathrm{CO}_{2}$ sensors in each classroom, they are not used to control the ventilation systems. Recommendations for demand controlled ventilation are discussed in Section 6.2. Occupancy sensors also control the heating and cooling set points for the classrooms. When a classroom is unoccupied, no outdoor air is supplied to the space and the temperature is controlled to a setback position. When the energy management system senses that the space is occupied, the temperature set point is switched to an occupied comfort position. The ventilation, heating, and cooling set points in the offices are manually controlled. The console heat pumps are singlepackage, ground-water-source Carrier heat pumps with capacity ratings that vary from 6,800 to 11,800 $\mathrm{Btu} / \mathrm{hr}(2.0-3.5 \mathrm{~kW})$ with an air supply of $275 \mathrm{cfm}$ to $350 \mathrm{cfm}\left(0.130 \mathrm{~m}^{3} / \mathrm{s}\right.$ to $\left.0.165 \mathrm{~m}^{3} / \mathrm{s}\right)$. According to the manufacturer's specifications, the heating efficiency of these units at the American Refrigeration Institute (ARI) standard 320-93 (ARI 2003a) ranges from a coefficient of performance (COP) of 4.6 for the smaller units to 3.9 COP for the larger units. The ARI-320-93 heating standard rates heat pumps at a $70^{\circ} \mathrm{F}\left(21^{\circ} \mathrm{C}\right)$ dry-bulb entering air temperature and $70^{\circ} \mathrm{F}\left(21^{\circ} \mathrm{C}\right)$ source water temperature. The cooling efficiency of these units at the ARI standard 320-93 is rated at an energy-efficient ratio (EER) of 12.8. The ARI-320-93 cooling standard rates heat pumps at $80^{\circ} \mathrm{F}\left(27^{\circ} \mathrm{C}\right)$ dry-bulb, $67^{\circ} \mathrm{F}\left(19^{\circ} \mathrm{C}\right)$ wet-bulb, and $85^{\circ} \mathrm{F}\left(29^{\circ} \mathrm{C}\right)$ source water temperature. The manufacturer does not recommend operation below $50^{\circ} \mathrm{F}$ $\left(10^{\circ} \mathrm{C}\right)$ source water temperature, as the heating capacity and COP are dramatically reduced (Carrier 2003). The manufacturer also expects the temperature of the source water of standard range heat pumps to be mechanically controlled within a temperature range of $60^{\circ} \mathrm{F}$ to $90^{\circ} \mathrm{F}\left(16^{\circ} \mathrm{C}\right.$ to $\left.32^{\circ} \mathrm{C}\right)$. In contrast, extended range heat pumps are designed and rated to operate at a source water temperature range of $25^{\circ} \mathrm{F}$ to $110^{\circ} \mathrm{F}\left(-4^{\circ} \mathrm{C}\right.$ to $\left.43^{\circ} \mathrm{C}\right)$. None of the heat pumps in the Lewis Center are extended range heat pumps. Problems associated with using standard range heat pumps are discussed in Section 6.2.2.

Ventilation supply air for the classrooms, offices, and corridors is handled by a single large, standard range water source heat pump, shown as HP-5 in Figure 4-14. According to the manufacturer's specifications, HP-5 has a nominal cooling capacity of 120,000 Btu/hr $(35.2 \mathrm{~kW})$ with an EER of 11.4 for cooling and a nominal heating capacity of $135,000 \mathrm{Btu} / \mathrm{hr}(39.6 \mathrm{~kW})$ with a COP of 3.8 for heating at ARI-320-93 standards. The HP-5 supply fan provides $3500 \mathrm{cfm}\left(4.7 \mathrm{~m}^{3} / \mathrm{s}\right)$ of ventilation air to occupied classrooms and offices. Ventilation supply air to the classrooms and offices is $100 \%$ outdoor air, as there is no mixing of supply and return air streams. An energy recovery ventilator (ERV-2 shown in 
Figure 4-14) transfers either heat or cold from the return/exhaust air to the supply air. The sensible and latent heat transfer rating (effectiveness) is $75 \%$ to $80 \%$ at balanced supply and exhaust airflow. The supply and return fans of ERV-2 are rated at $2500 \mathrm{cfm}\left(1.18 \mathrm{~m}^{3} / \mathrm{s}\right)$ and $1350 \mathrm{cfm}\left(0.637 \mathrm{~m}^{3} / \mathrm{s}\right)$, respectively. The control of the supply fan, return fan, and enthalpy wheel of ERV-2 is linked to HP-5 so that when HP-5 is on, ERV-2 is also on. When a classroom is occupied and the ventilation damper opens, HP-5 and ERV-2 condition and supply 100\% outdoor air to the occupied space. A pressure-controlled bypass damper ensures a constant duct pressure. While each ventilated room includes a $\mathrm{CO}_{2}$ sensor connected to the EMS, the outdoor air is controlled based on occupancy sensors. Improved control of this outdoor air system is discussed in Section 7.2.

Because HP-5 is a standard-range water source heat pump, the minimum recommended source water temperature is $50^{\circ} \mathrm{F}\left(10^{\circ} \mathrm{C}\right)$. To supply this source temperature range, a $112-\mathrm{kW}$ electric boiler was installed to preheat source water for the standard range heat pump. This is shown in the piping schematic in Figure 4-15.

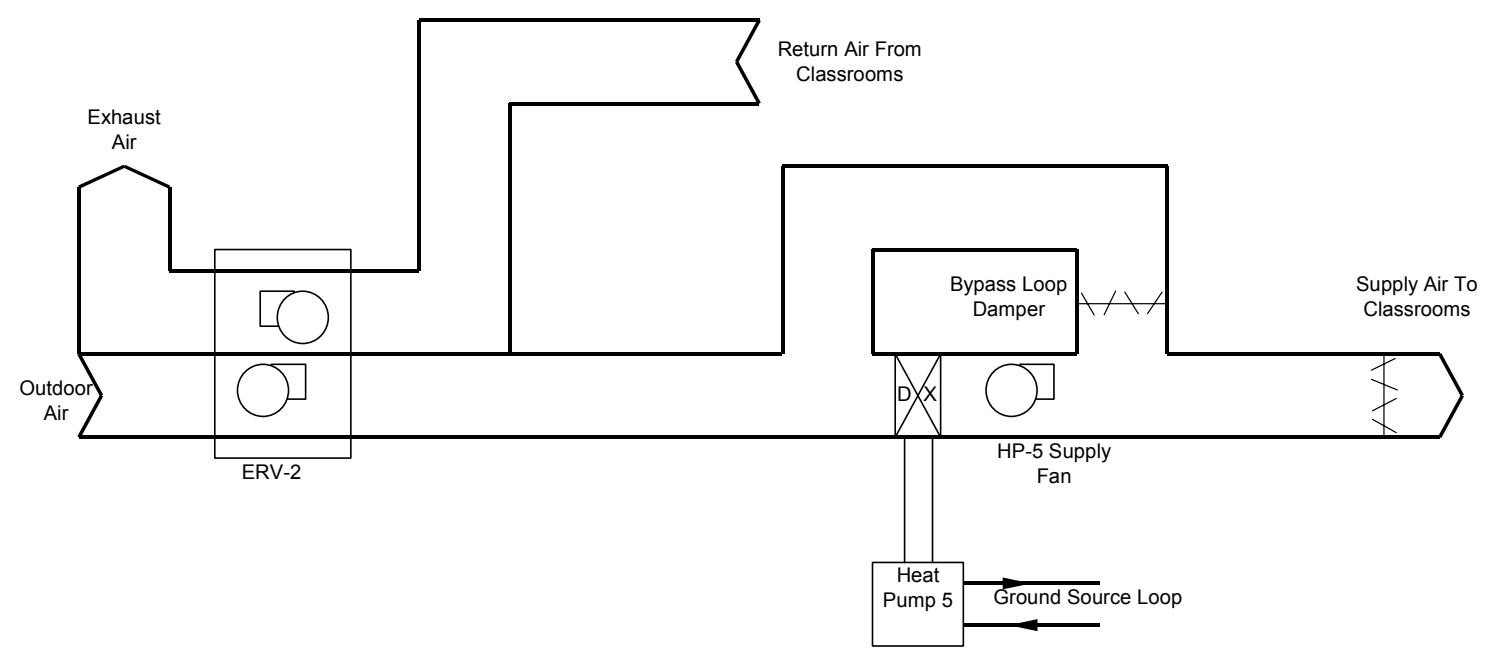

Figure 4-14 HP-5 and ERV-2 mechanical schematic 


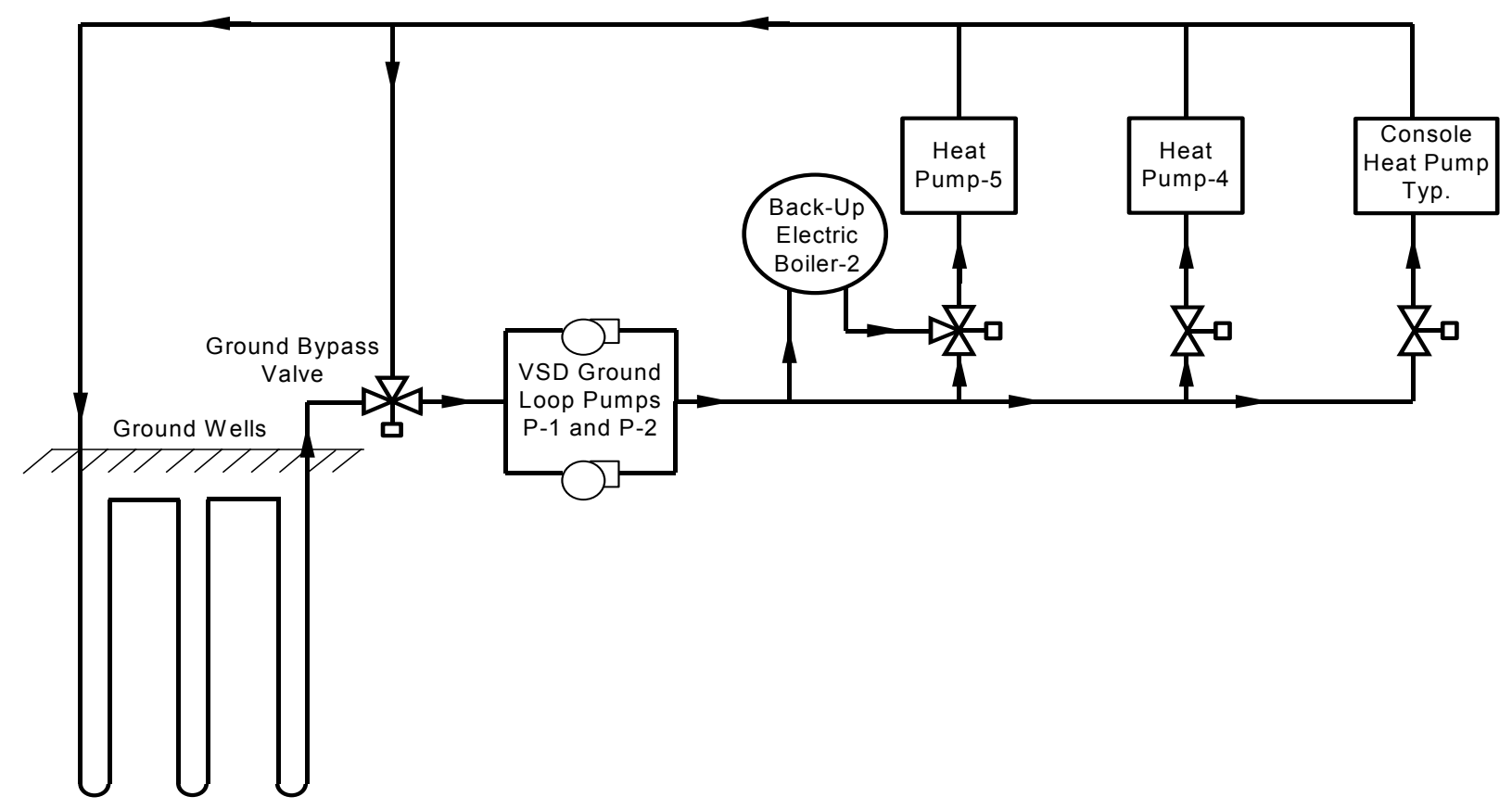

Figure 4-15 Ground loop heat pump piping schematic

To supply heating, cooling, and ventilation to the auditorium, another standard-range water heat pump, shown as heat pump 4 (HP-4) in Figure 4-16, provides conditioned supply air. This system also has the capability to provide conditioned outdoor air to the atrium. HP-4 ducting was designed to supply conditioned air to the auditorium and atrium. According to the manufacturer's specifications (Carrier 2003), HP-4 has a nominal cooling capacity of 74,000 Btu/hr $(21.7 \mathrm{~kW})$ with an EER of 14.0 for cooling and a heating capacity of $83,000 \mathrm{Btu} / \mathrm{hr}(24.3 \mathrm{~kW})$ with a COP of 4.2 for heating at ARI-320-93 standards. HP-4's supply fan provides $2500 \mathrm{cfm}\left(1.18 \mathrm{~m}^{3} / \mathrm{s}\right)$ of ventilation air to the auditorium and atrium. This system is controlled to switch from setback temperature set points to an occupied comfort condition based on a preset schedule. This schedule is programmed based on class and special function schedules. A system override provides for unscheduled occupancy. A mixed air damper and ductwork allows for mixing of return and supply air. An energy recovery wheel is also used to transfer heat or cold from the exhaust air to the supply. The sensible and latent heat transfer effectiveness rating is $75 \%$ to $80 \%$. The supply fan of ERV-1 is rated at $1500 \mathrm{cfm}\left(0.71 \mathrm{~m}^{3} / \mathrm{s}\right)$; the return fan of ERV-1 is rated at $1350 \mathrm{cfm}\left(0.637 \mathrm{~m}^{3} / \mathrm{s}\right)$. The control of the supply fan, return fan, and enthalpy wheel of ERV-1 is linked to HP-4 so that when HP-4 is on, ERV-1 is also on. A pressure-controlled bypass damper ensures constant duct pressure.

A closed loop, geothermal well system acts as heat source and sink for the glycol-water source side of the heat pumps. A set of variable speed drive (VSD) 5-hp (3.7-kW) pumps (P1 and P2) circulates the glycolwater mix through $24240-\mathrm{ft}(73-\mathrm{m})$ deep ground wells and to the heat pumps. Note that the two pumps are part of a redundant system and that only one pump operates at a time. The ground loop pumps (P1 or $\mathrm{P} 2$ ) are controlled to provide a constant pressure difference between the water supply and return (see the loop schematic in Figure 4-15). When there is no demand for the ground source loop, the VSD controls $\mathrm{P} 1$ (or P2) to $5 \%$ of full rated pump power. The temperature of the water from the ground loop supplied to the source side of the heat pumps is typically between $45^{\circ} \mathrm{F}$ and $77^{\circ} \mathrm{F}\left(7.2^{\circ} \mathrm{C}-25^{\circ} \mathrm{C}\right)$. 


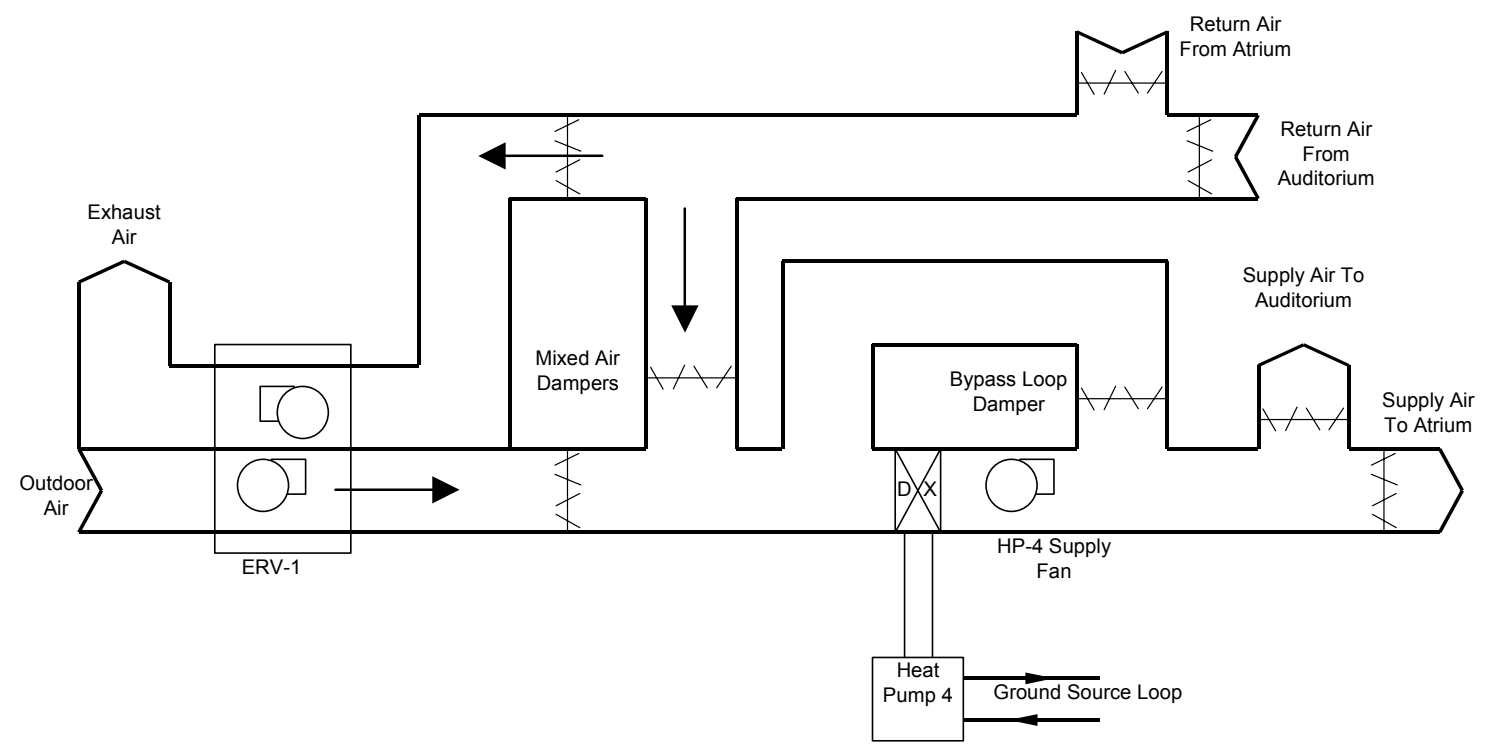

Figure 4-16 HP-4 and ERV-1 mechanical schematic

A separate hydronic heating system heats the atrium, wastewater treatment sunspace, bathrooms, stairwells, and kitchen. Local fan-coil units heat the stairways, bathrooms, and kitchen; there is no mechanical cooling for these spaces. In the atrium, a radiant floor heating system furnishes heating; the cooling can be supplied by natural ventilation or HP-4. The atrium was heated to $70^{\circ} \mathrm{F}\left(21^{\circ} \mathrm{C}\right)$ during occupied hours with a night setback. Local fan-coil units and a baseboard radiator heat the wastewater treatment sunspace. The wastewater treatment space was heated at $70^{\circ} \mathrm{F}\left(21^{\circ} \mathrm{C}\right)$ without a setback. There is no mechanical cooling for this space. A $112-\mathrm{kW}$ electric boiler heats this water loop. A constant speed 0.5 -hp $(373-\mathrm{W})$ pump $(\mathrm{P} 3$ or $\mathrm{P} 4)$ supplies mixed tempered hot water $\left(110^{\circ} \mathrm{F}\right.$ or $\left.43^{\circ} \mathrm{C}\right)$ to the radiant floor heating loops in the atrium. Constant speed 1.0-hp (746-W) pumps (P5 or P6) alternately supply hot water $\left(140^{\circ} \mathrm{F}\right.$ or $\left.60^{\circ} \mathrm{C}\right)$ to the fin tube and fan-coil heating system in the wastewater treatment, kitchen, bathrooms, and stairwells. This system is illustrated in Figure 4-17. The energy efficient design intent of the ground source heat pump system was not evident in the hydronic system and the $112-\mathrm{kW}$ electric boiler design, as discussed in Section 5.2.3.1. 


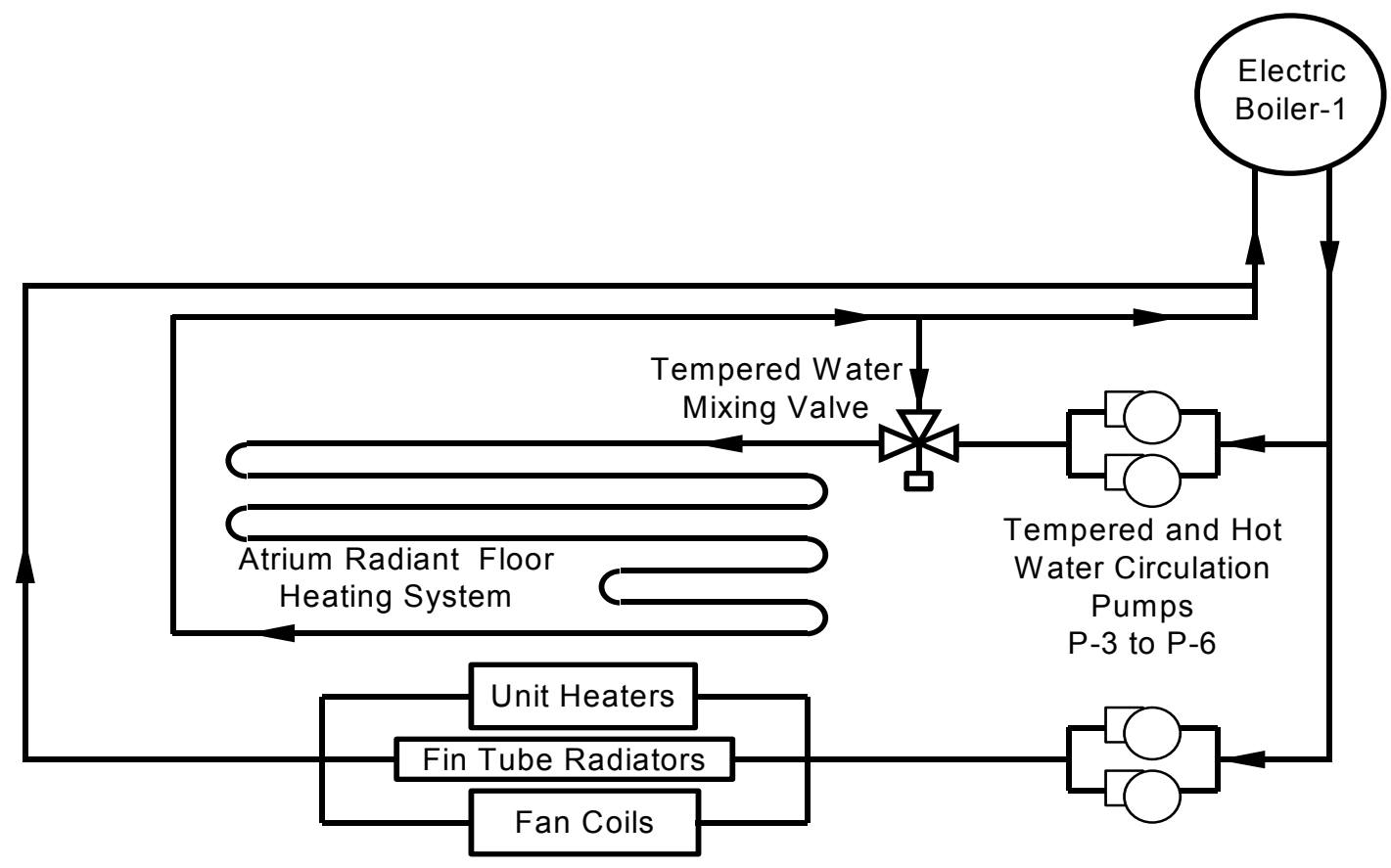

Figure 4-17 Hydronic heating system piping schematic

A $0.5-\mathrm{hp}(373-\mathrm{W}), 2000-\mathrm{cfm}\left(0.9-\mathrm{m}^{3} / \mathrm{s}\right)$, nominally rated exhaust fan directly extracts conditioned air from the wastewater treatment to the outside throughout the year. The speed of this exhaust fan can be manually controlled to limit the unwanted odors from the wastewater treatment system's organic processes that might infiltrate the main spaces of the building. This exhaust fan airflow has been measured to be between 1200 and $1300 \mathrm{cfm}\left(0.57 \mathrm{~m}^{3} / \mathrm{s}\right.$ to $\left.0.61 \mathrm{~m}^{3} / \mathrm{s}\right)$ under typical operation. The energy performance consequences of the wastewater treatment exhaust is discussed in Section 6.1. Smaller exhaust fans ranging from $75-300 \mathrm{cfm}\left(0.04-0.14 \mathrm{~m}^{3} / \mathrm{s}\right)$ remove air from the bathrooms, kitchen, and mechanical rooms. The bathroom exhaust fans are controlled through an occupancy sensor; the kitchen and mechanical room fans are thermostatically controlled. All of the exhaust fans vent directly to the outside.

\subsection{Equipment}

Equipment in the Lewis Center includes all connected plug loads that are not associated with heating, cooling, ventilation, or lighting. The equipment in the wastewater treatment laboratory includes multiple water pumps and water treatment equipment such as ultraviolet lights and bubblers. A 4.6-kW, 40-gal (150-L) electric hot-water heater supplies domestic hot water for the bathrooms and kitchen. Office equipment includes computers and monitors, task lighting, a copier, a fax machine, and printers. Classroom equipment includes overhead and digital projectors. Elevator equipment includes controls, elevator cabin lighting, hydraulics, and an oil heater. Other equipment includes automatic window openers, monitoring and control equipment, auditorium audio and visual equipment, and a microwave in the kitchen. The circuits on this unit include telecommunications, fire alarms, emergency lighting, and exit signs. 


\section{Whole-building Energy Evaluation}

\subsection{Whole-building Evaluation Methodology}

The NREL High-Performance Buildings team, in collaboration with students and faculty from the Oberlin College Environmental Studies Program, began the whole-building analysis by measuring the energy consumption at many end uses as well as energy supplied to the building from the PV system and the utility company. Researchers then verified that the energy data collection meters were working properly through an energy balance at the building's main electrical distribution panel. After NREL confirmed that the meters were working properly, energy performance metrics were measured. Researchers then created a computer-simulated building model of a conventional energy code compliant building (base case) and a model of the Lewis Center building as constructed (as-built). The evaluation timeline is diagrammed in Figure 5-1.
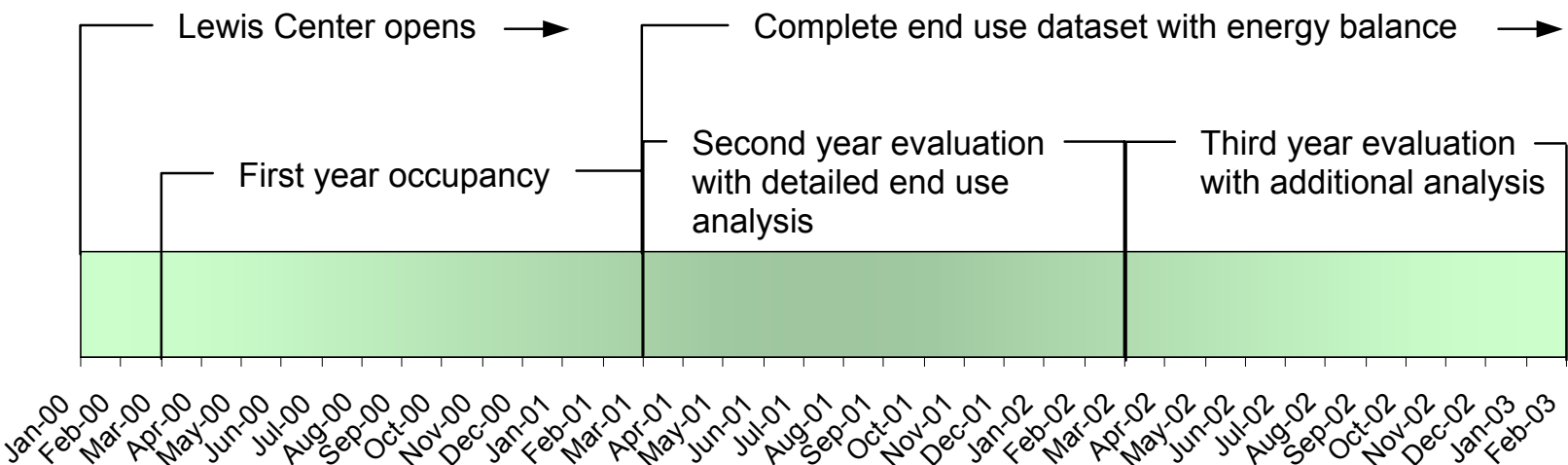

Figure 5-1 Evaluation timeline

Although detailed monitoring was not available during the first year of occupancy (March 2000 through February 2001), monthly utility bills provided some data for a summary analysis. During the first year, we considered annual energy cost intensity, site energy use intensity, and source energy use intensity.

For the second year (March 2001 through February 2002), NREL considered the following additional measurements: seasonal load shape profiles, detailed end use analysis, an electrical demand and cost analysis, specific systems performance, and the measured site weather. The results from the second year of whole-building analysis included annual energy cost intensity, measured site energy use intensity, measured PV production, measured net site use, and measured source use intensity. These wholebuilding summary performance metrics were also used for analysis of the third year of building operation (March 2002 through February 2003). Additional analysis of measured end use data and utility bills are provided for the third year to study changes made during the evaluation period.

The conventional and as-built buildings were modeled to calculate energy savings for typical weather years and to provide an energy benchmark. As-built models were calibrated against measured performance and driven by measured weather data. Performance metrics analyzed include site energy savings, source energy savings, and site cost energy savings. A single calibrated as-built model and a reference model were created for the second and third year of operation, with results provided for both years. The flow chart in Figure 5-2 shows how the measured data was used in the models and the process used to obtain the simulation results. 


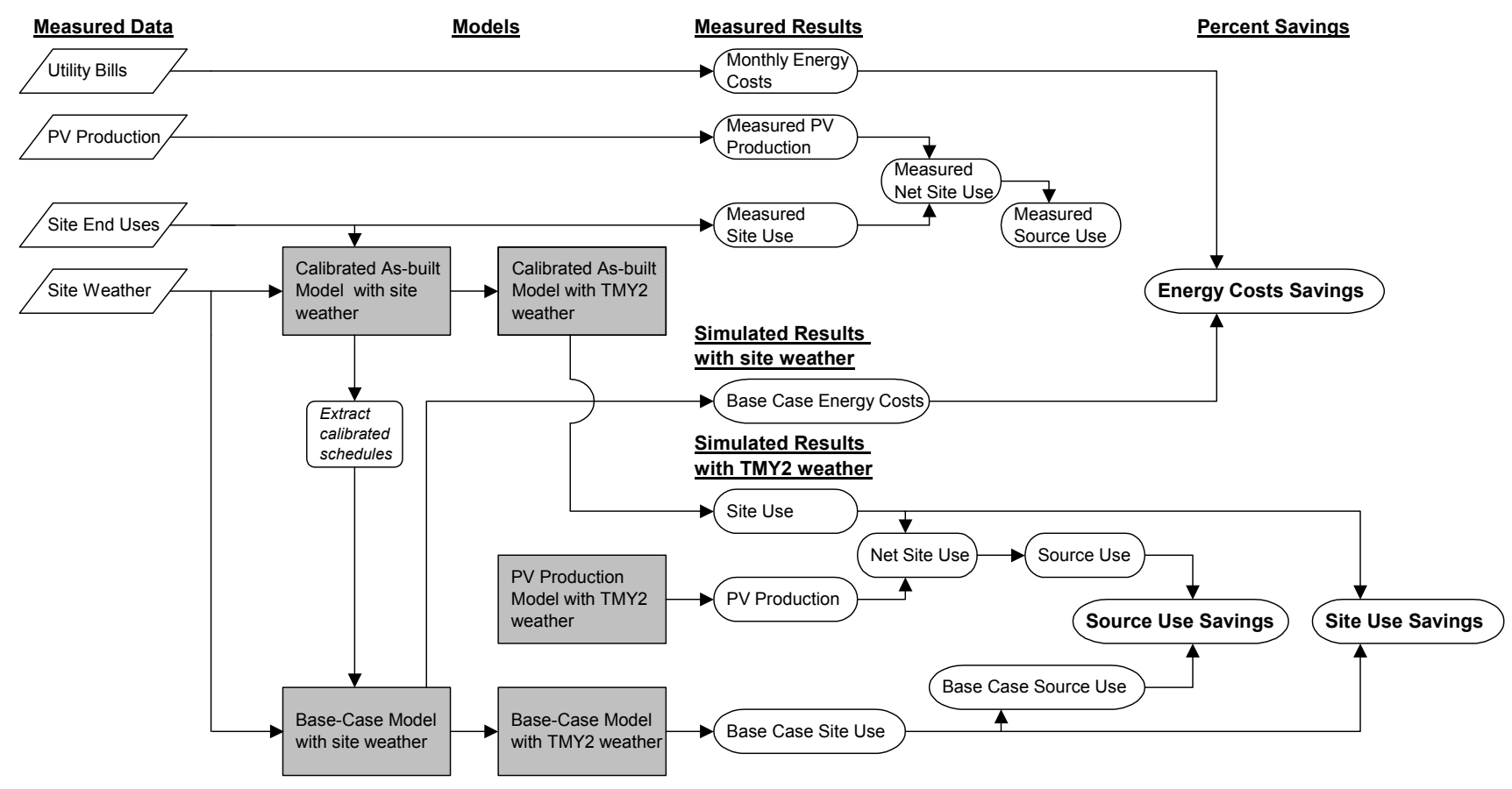

Figure 5-2 Whole-building evaluation flowchart

\subsection{Whole-building Monitoring}

\subsubsection{Building Monitoring Methods}

The NREL and Oberlin team installed a permanent data acquisition system (DAS) to measure energy flows of the Lewis Center. Energy flows were measured with watt-hour meters. These meters converted the electrical energy measurements into pulse outputs. The DAS recorded the pulses as minute and hourly totals. The manufacturer of the watt-hour meters reports the accuracy to be $0.45 \%$ of the reading (Continental Controls Systems 2003). The DAS also measured pulses directly from utility meters. As shown in Figure 5-3 as UM1, the utility meter measured electricity supplied to the building from the utility grid on the primary side of the $500-\mathrm{kVA}$ building transformer. The DAS and the utility company both measured the electricity supplied to the building by the PV system. Figure 5-3 shows this meter as UM2. The calculated meters (CM1 through CM6 in Figure 5-3) were computed, rather than measured, and represent the difference when performing an energy balance around the electrical main distribution panel (MDP) or subpanels. Figure 5-4 and Figure 6-11 also show additional PV metering information. 


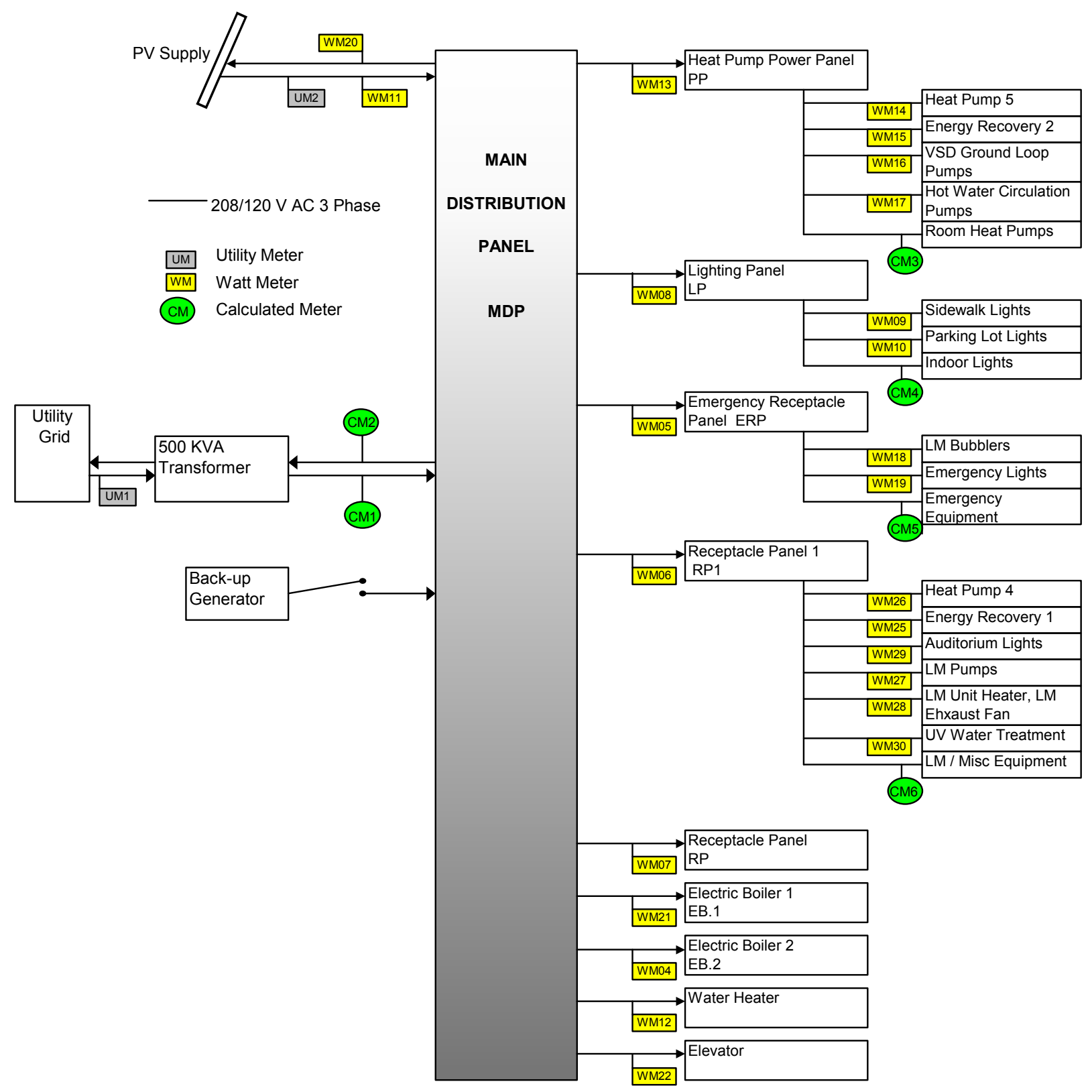

Figure 5-3 Single-line building electrical system plan and DAS meter locations

By metering and recording each end use, the DAS was able to report aggregated energy consumption in the categories of HVAC, lighting, and equipment. Table 5-1 shows the end use category structure. Also included in Table 5-1 are total consumption, total AC PV production, and net use labels. Total consumption was calculated by summing all the end use categories in the building. The total consumption calculation includes sidewalk and parking lot lighting and on-site wastewater treatment equipment. The total electricity consumption in the building did not include electricity losses resulting from inefficiencies in the building transformer. The net building use was calculated by subtracting the total AC PV production from the total building consumption. When the net energy use is negative, the building is exporting energy because the PV system is generating more electricity than the building is consuming. Actual meters were not used in place of CM1 and CM2 because these energy flows were 
calculated with the existing meters. Additionally, it was not physically practical to install metering equipment on the main feeds to the building.

Table 5-1 Building Electrical End Use Metered Data Points

\begin{tabular}{|c|c|}
\hline Meter Label & End Use Label \\
\hline $\begin{array}{c}\text { WM04+WM05+WM06+WM07+WM08+WM12+WM13 } \\
\text { +WM20+WM21+WM22 }\end{array}$ & Total Building Consumption \\
\hline WM11 and UM2 & Total AC PV Production \\
\hline CM1 or CM2 & Net Building Use \\
\hline UM1 & Utility Net Site Use (Consumption only) \\
\hline \multicolumn{2}{|l|}{ HVAC } \\
\hline WM21 & Electric Boiler 1 (EB-1) \\
\hline WM04 & Electric Boiler 2 (EB-2) \\
\hline WM26 & Heat Pump 4 (HP-4) \\
\hline WM14 & Heat Pump 5 and duct heaters (HP-5) \\
\hline WM25 & Energy Recovery Ventilator 1 (ERV-1) \\
\hline WM15 & Energy Recovery Ventilator 2 (ERV-2) \\
\hline CM3 & Room Console Heat Pumps \\
\hline WM16 & VSD Ground Pumps \\
\hline WM17 & Circulation Pumps \\
\hline \multicolumn{2}{|l|}{ LIGHTS } \\
\hline CM4 & Indoor Lights \\
\hline WM29 & Auditorium Lights \\
\hline WM19 & Emergency Lights \\
\hline WM09 & Side Walk Lights \\
\hline WM10 & Parking Lot Lights \\
\hline \multicolumn{2}{|c|}{ EQUIPMENT } \\
\hline WM07 & Office and Classroom Receptacles \\
\hline CM5 & Emergency Equipment \\
\hline WM20 & PV System Consumption \\
\hline WM22 & Elevator \\
\hline WM12 & Domestic Hot Water \\
\hline WM27+WM28+WM30+WM18+CM6 & $\begin{array}{l}\text { Wastewater Treatment and } \\
\text { Miscellaneous Auditorium Equipment }\end{array}$ \\
\hline
\end{tabular}

Redundant meters were used to ensure monitoring quality. WM11 and UM2 in Figure 5-3 both measure and record the AC PV production. Another monitoring quality measure applied was an energy balance around the main distribution panel. The energy balance required all the energy into the building at the MDP to equal all of the energy used in the building at the MDP. When the building is not operating as a net energy exporter, and all meters are functioning correctly, UM1 equals the sum of CM1 and building transformer losses. When the building is exporting to the utility (net energy exporter), this energy balance is inaccurate, as UM1 measures only the energy coming into the building from the utility.

In addition to metering the electrical energy flows, the DAS recorded multiple thermal performance measurements. Air temperature was measured at the inlet and outlet of each ERV unit. The temperature 
in the atrium was measured at seven locations from the floor to the ceiling. The relative humidity of the space was also measured. This measured temperature stratification through the height of the atrium. The wastewater treatment system temperature and relative humidity were measured as well. The water temperatures in the heat pump loop from the building to the ground and from the ground to the building were measured. Lewis Center faculty and students measured other environmental conditions in the surrounding landscape and wastewater treatment performance related variables. The DAS monitored the energy flows of the PV system. The information in Table 5-2 was collected to evaluate the PV system performance. Additional PV performance measurements include PV cell temperature at $-3.0^{\circ}, 0.0^{\circ}$, and $3.0^{\circ}$ tilt angles of subarray A.

Table 5-2 PV System Metered Data Points

\begin{tabular}{|l|l|}
\hline \multicolumn{1}{|c|}{ Meter Labels } & \multicolumn{1}{|c|}{ Label in Figure 5-4 } \\
\hline \hline PV DC current and voltage for each subarray & ShVd1, ShVd2, ShVd3 \\
\hline PV AC power produced & WM 11 \\
\hline AC power used by the PV system during inverter standby mode (back feed) & WM 20 \\
\hline PV AC power exported to the utility & CM 1 \\
\hline Total AC power purchased from the utility & CM 2 \\
\hline Total AC power consumed in the building & WM 4 - WM 21 \\
\hline
\end{tabular}

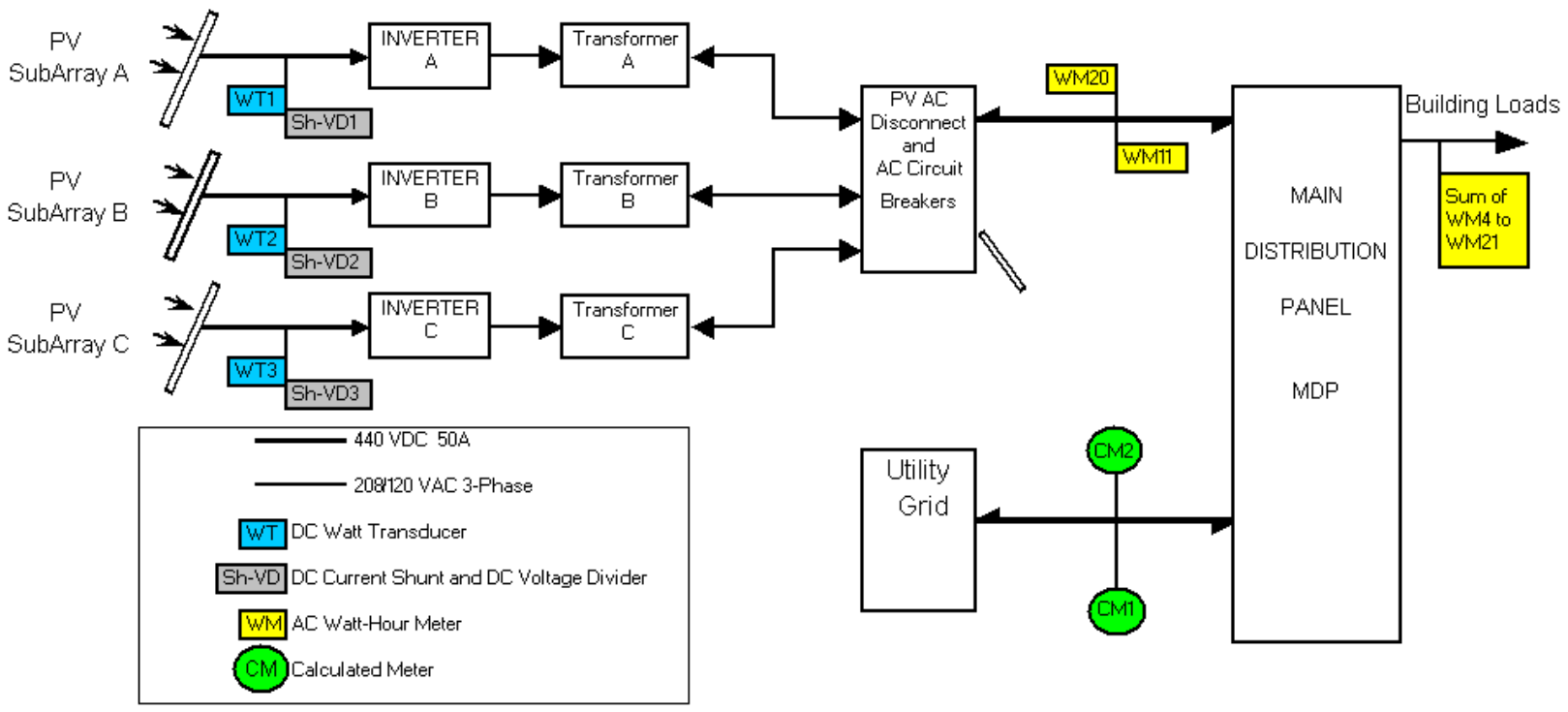

Figure 5-4 Single-line PV electrical system plan and data acquisition meter locations

An on-site weather station measures outdoor dry-bulb temperature, relative humidity, wind speed and direction, horizontal and southern vertical insolation, photosynthetically active radiation, precipitation, and air pressure.

NREL recorded and documented all these metered variables in minute and hourly totals or averages from March 1, 2001 through February 28, 2003. Detailed analysis is provided for the first year of monitoring (March 2001 through February 2002), with additional analysis provided for the second year of monitoring (March 2002 through February 2003). 


\subsubsection{Monitoring System Analysis and Uncertainty}

The DAS system used for this evaluation consisted of two Campbell Scientific data loggers with battery backup, various pulse and voltage measurement multiplexers, a network interface, and all the necessary sensors discussed previously. Data from the meters were downloaded from the data logger every few minutes to a local server. From there, the hourly data were transferred into an analysis and error checking spreadsheet program daily. The minute data were stored on the server and used when more detailed analysis was needed. The spreadsheet program calculated an energy balance and presented summary data for easy inspection. The energy balance at the main distribution panel was used as the error checking procedure to verify that each meter was measuring properly. The energy balance aids in identifying any errors in the metering installation and DAS programming. Figure 5-5 illustrates this check and shows the overall accuracy of the metering system.

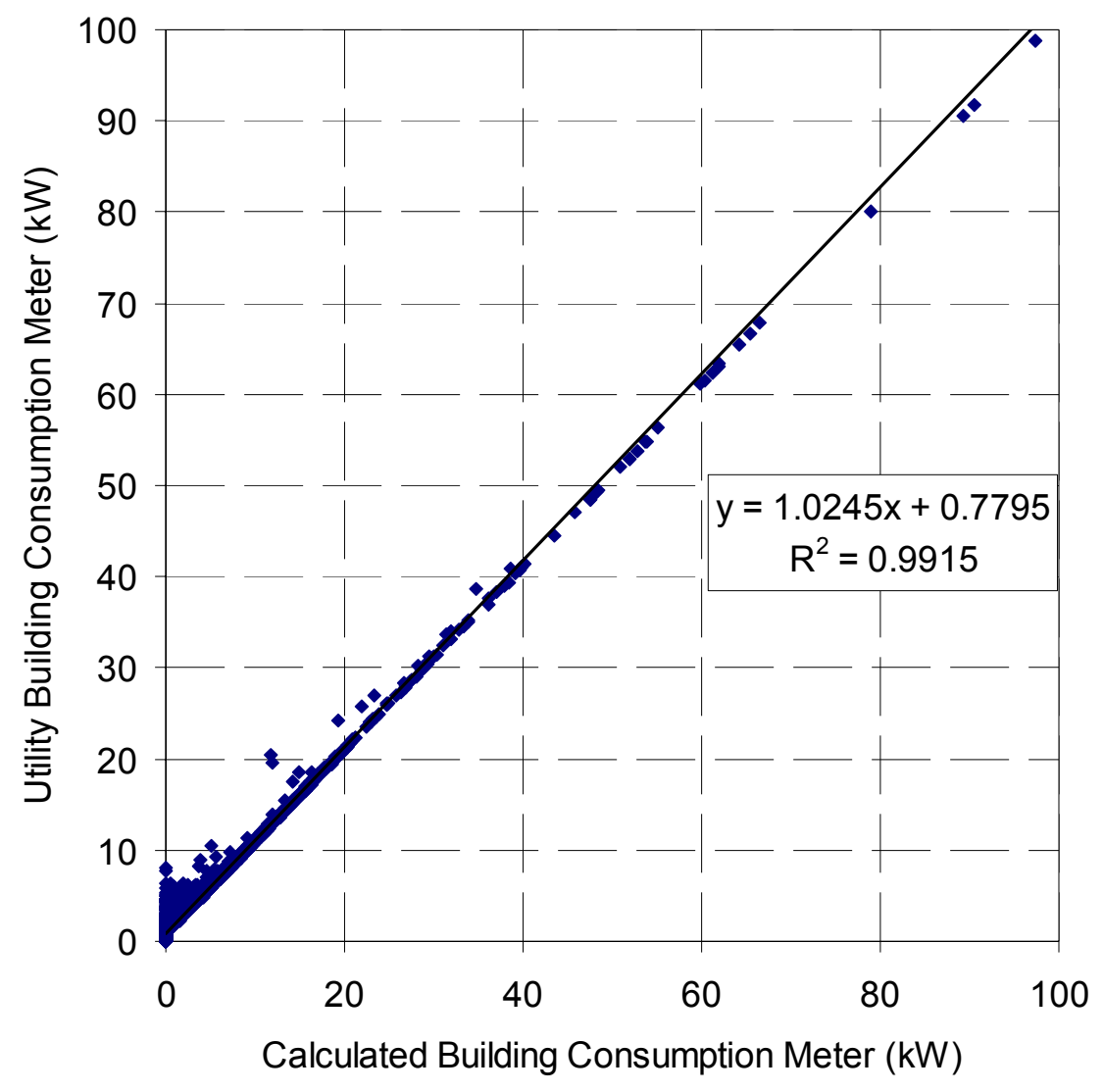

Figure 5-5 X-Y plot of calculated building electricity utility supply (CM1) versus utility meter electricity supply (UM1)

Figure 5-5 is an X-Y plot of the building utility meter (UM1) on the y-axis and the calculated building electricity use meter (CM1) on the x-axis. If any of the end use meters used to calculate the electricity supply to the building (CM1) were incorrect, this plot would reveal this error. The trend line slope of 1.02 demonstrates that the meters are working within acceptable accuracy. The y-intercept of the trend line is $0.78 \mathrm{~kW}$. The offset and $2 \%$ load corresponds to expected losses of the $500-\mathrm{kVA}$ building transformer. The location of the utility meter and the calculated inferred meter with respect to the building transformer can be seen in Figure 5-3. The high variability of the building transformer at no load (zero net building consumption) is shown by the 2.0 - to $8.0-\mathrm{kW}$ discrepancy of the energy balance in this operating range. From a total energy perspective, this number is small. Although the building 
transformer is owned by the Lewis Center, the building loads reported here are based on the building side of the transformer, and not the utility meter. It is typical of buildings of this size to meter the building side of the transformer, which leaves the responsibility for the transformer to the utility and not the building owner.

Using a dedicated monitoring system for collecting evaluation data was functional, practical, and very reliable. As with any long-term measurement project, missing data is possible even with reliable and dedicated equipment and sensors. Over the two-year period of monitored minute and hourly end use data, $0.6 \%$ of the collected hourly data was incomplete or missing. Of the 56 variables that were collected on an hourly time step, only 6,000 data points were missing or incomplete over the two years. A typical error was a missing hour of all end use variables. To account for this type of error, NREL inspected diurnal, weekly, and seasonal patterns in the end uses, combined with a driving variable, such as weather and occupancy, to estimate the missing data points.

The expected accuracy of the sensors used in the monitoring system is determined from product specifications and is shown in Table 5-3. Individual electricity measurements are $\pm 0.5 \%$ based on manufacturer's data. Totaled values are a summation of as many as 11 individual measurements but the errors are assumed to be independent and to not increase the level of uncertainty. Based on the expected uncertainty of the energy use measurements and the reliability of the long term DAS, NREL expected the uncertainty of the annual performance metrics based on measured energy use to be $\pm 1 \%$.

Table 5-3 Measurement Type Accuracy

\begin{tabular}{|l|c|}
\hline \multicolumn{1}{|c|}{ Measurement Type } & Sensor Accuracy \\
\hline $\begin{array}{l}\text { WattNode Watt-hour meter for electrical } \\
\text { end use measurements }\end{array}$ & $\pm 0.5 \%$ \\
\hline $\begin{array}{l}\text { Standard type T thermocouple for PV cell } \\
\text { temperatures, ERV air temperatures, and } \\
\text { heat pump ground loop temperatures }\end{array}$ & $\pm 0.5^{\circ} \mathrm{C}$ \\
\hline $\begin{array}{l}\text { Temperature and RH probes for ambient, } \\
\text { atrium, and wastewater treatment } \\
\text { environmental conditions }\end{array}$ & $\begin{array}{c} \pm 3 \% \mathrm{RH} \text { for } 10-90 \% \mathrm{RH}, \pm 6 \% \\
\text { for } 90-100 \% \mathrm{RH}, \pm 0.5^{\circ} \mathrm{C}\end{array}$ \\
\hline $\begin{array}{l}\text { Empro DC current shunts for DC current of } \\
\text { PV Systems }\end{array}$ & $\pm 0.25 \%$ \\
\hline $\begin{array}{l}\text { Voltage dividers for DC voltage of PV } \\
\text { system }\end{array}$ & $\pm 1.0 \%$ \\
\hline $\begin{array}{l}\text { LiCor solar radiation pyranometer for } \\
\text { outdoor horizontal and vertical insolation }\end{array}$ & $\pm 5.0 \%$ \\
\hline
\end{tabular}

The uncertainty of the annual performance metrics based on simulations, such as site energy savings and site energy use intensity for a typical weather year, are difficult to estimate with direct calculations. The processes used in the whole-building analysis attempts to reduce uncertainty related to building simulations. To reduce the uncertainty of the annual simulation metrics, NREL calibrated the models with measured end uses and site weather. As discussed further in the calibration procedure in Section 5.3.4, NREL considers a building simulation to be calibrated when the simulated monthly energy use is within $\pm 12 \%$ of the measured monthly energy use (Energy Simulation Specialists, Inc. 1995). This $\pm 12 \%$ criteria can be assumed to represent a base level of uncertainty in annual performance metrics based on simulation results.

Input perturbation methods can also be used to model the uncertainty in whole building energy simulations, but require an extensive level of effort to prepare hundreds of input files and process results. Such efforts have produced error estimates of about $\pm 14 \%$ (Griffith, 2004). Based on these two methods, NREL estimates the uncertainty of the annual performance based on simulation to be $\pm 12 \%$. Note that 
uncertainties of the simulated performance are much lower for percent saving metrics, which is a result of the comparison of one simulation to another simulation (e.g. base case to as-built). Because difficult-toknow inputs are held the same in both simulations, such comparisons remove much of the uncertainty inherent in an hourly building energy simulation. Variables that change throughout the year, such as inconsistent occupancy, set point changes, and equipment performance degradation, are difficult to account for in an annual building energy simulation. By comparing a base-case model to an as-built model with the same schedules, the uncertainty caused by these inconsistent variables is reduced. Future work in this area could include a differential sensitivity analysis to quantify the increased accuracy of the simulation-to-simulation comparison method. This type of uncertainty analysis was not performed for the Lewis Center energy evaluation, as this is beyond the scope of this report.

\subsubsection{March 2001-February 2002 Measured Data Analysis}

After monitoring the Lewis Center for a full year, NREL was able to calculate the primary annual performance metrics, with expected uncertainty as discussed in the previous section. At a gross floor area of $13,600 \mathrm{ft}^{2}\left(1260 \mathrm{~m}^{2}\right)$, the second year site consumption energy intensity was $30.6 \mathrm{kBtu} / \mathrm{ft}^{2} \cdot \mathrm{yr}$ $\left(348 \mathrm{MJ} / \mathrm{m}^{2} \cdot \mathrm{yr}\right)$. The PV system produced $59,518.5 \mathrm{kWh}(214,266.6 \mathrm{MJ})$, or $14.9 \mathrm{kBtu} / \mathrm{ft}^{2} \cdot \mathrm{yr}$ $\left(169 \mathrm{MJ} / \mathrm{m}^{2} \cdot \mathrm{yr}\right)$. On an annual basis, the PV system produced $49 \%$ of the electricity consumed in the Lewis Center. The net annual site consumption intensity, including PV production, was $15.7 \mathrm{kBtu} / \mathrm{ft}^{2} \cdot \mathrm{yr}$ $\left(178 \mathrm{MJ} / \mathrm{m}^{2} \cdot \mathrm{yr}\right)$. This net site consumption results in a source energy intensity of $50.6 \mathrm{kBtu} / \mathrm{ft}^{2} \cdot \mathrm{yr}(575$ $\mathrm{MJ} / \mathrm{m}^{2} \cdot \mathrm{yr}$ ). Source energy is the sum of the energy directly consumed at the site and the energy consumed by producing and delivering energy products. Source energy was calculated based on $31 \%$ electricity conversion and delivery efficiency from source to site. The electrical source-to-site efficiency was based on the conversion and distribution efficiency averaged over all sources of electricity generation in the nation (EIA 2000).

Based on utility bills during the second year of occupancy, the energy cost intensity was $\$ 1.17 / \mathrm{ft}^{2}$ $\left(\$ 12.59 / \mathrm{m}^{2}\right)$. Further energy cost analysis is provided in Section 5.2.3.2. The measured whole-building results for the second year of operation are shown in Table 5-4. As this energy performance is far from the design vision of a net energy exporter, a detailed evaluation was performed.

Table 5-4 Measured Whole-building Results, Second Year of Operation

\begin{tabular}{|c|c|c|c|c|c|c|}
\hline & $\begin{array}{c}\text { Measured } \\
\text { Site Use } \\
\text { Intensity } \\
\mathrm{kBtu} / \mathrm{ft}^{2} \\
\left(\mathrm{MJ} / \mathrm{m}^{2}\right)\end{array}$ & $\begin{array}{c}\text { Measured PV } \\
\text { Production } \\
\text { Intensity } \\
\mathrm{kBtu} / \mathrm{ft}^{2} \\
\left(\mathrm{MJ} / \mathrm{m}^{2}\right)\end{array}$ & $\begin{array}{c}\text { Percent of } \\
\text { Building Load } \\
\text { Met By PV }\end{array}$ & $\begin{array}{c}\text { Measured } \\
\text { Net Site Use } \\
\text { Intensity } \\
\mathrm{kBtu} / \mathrm{ft}^{2} \\
\left(\mathrm{MJ} / \mathrm{m}^{2}\right)\end{array}$ & $\begin{array}{c}\text { Measured } \\
\text { Source Use } \\
\text { Intensity } \\
\mathrm{kBtu} / \mathrm{ft}^{2} \\
\left(\mathrm{MJ} / \mathrm{m}^{2}\right)\end{array}$ & $\begin{array}{c}\text { Energy Cost } \\
\text { Intensity } \\
\$ / \mathrm{ft}^{2}\left(\$ / \mathrm{m}^{2}\right)\end{array}$ \\
\hline $\begin{array}{c}\text { March 2001 } \\
\text { through }\end{array}$ & $\begin{array}{c}30.6 \\
\text { February 2002 }\end{array}$ & $\begin{array}{c}14.9 \\
(169)\end{array}$ & $49 \%$ & $\begin{array}{c}15.7 \\
(178)\end{array}$ & $\begin{array}{c}50.6 \\
(575)\end{array}$ & $\begin{array}{c}1.17 \\
(12.59)\end{array}$ \\
\hline
\end{tabular}

NREL measured the electricity consumption of the primary end uses to determine the daily electrical consumption and production of the building. Figure 5-6 summarizes the building daily energy consumption and production from March 1, 2001 through February 28, 2002. For each month, the total electricity used for heating, cooling, lighting, and equipment, as well as that produced by PV, is normalized by dividing each value by the number of days in the corresponding month. This allows energy performance to be compared from month to month. The energy values reported in Figure 5-6 are from the secondary (building) side of the building transformer. Also shown in Figure 5-6 is the percent of building load that was met by PV on a monthly basis. During June and July, more electricity was produced by the PV system than was consumed in the building. For these months, the building operated as a net energy exporter because the PV production was the greatest for these months and energy 
consumption was low. For the month of July, when the building was conditioned as if the classrooms and auditorium were occupied on a daily basis, the PV system was able to meet the entire building load. For the month of March, when the 112-kW electric boiler EB-1 operated continuously for the entire month, the PV system only met $17.5 \%$ of the building load.

As Figure 5-6 illustrates, the electricity consumption during the month of March 2001 was dominated by heating requirements. The majority of March's heating was supplied by the constant operation of EB-1 ( 24 hours a day, 7 days a week), which was primarily used to heat the atrium floor, the wastewater treatment system, and the stairways. In March alone, EB-1 consumed $14,489 \mathrm{kWh}$, or $56 \%$ of the total electricity consumed that month. A large portion of the hot water from EB-1 was used in the unit heater and radiators in the wastewater treatment system to keep the zone temperature at $70^{\circ} \mathrm{F}\left(21^{\circ} \mathrm{C}\right)$ for 24 hours a day throughout the month. A constant 2000-cfm $\left(0.9 \mathrm{~m}^{3} / \mathrm{s}\right)$ exhaust fan that directly ventconditioned the wastewater treatment system air also contributed to this heating load. To reduce the demand for EB-1 during the winter of 2001-2002, the heating set point in the wastewater treatment system was reduced from a constant $70^{\circ} \mathrm{F}$ to $50^{\circ} \mathrm{F}\left(21^{\circ} \mathrm{C}\right.$ to $\left.10^{\circ} \mathrm{C}\right)$. The radiant floor heating system was shut off and HP-4 (rated at a COP of 3.8) was controlled to heat the atrium. EB-1 was still used to heat the wastewater treatment system to $50^{\circ} \mathrm{F}\left(10^{\circ} \mathrm{C}\right)$, along with the bathrooms, the kitchen, and the corridors. These control changes allowed for a more efficient atrium heating system to operate during the winter of 2001-2002, and the reduced heating energy consumption seen was largely a result of these changes.

While these control changes reduced the operation of the EB-1, they did not completely eliminate the use of the boiler. When EB-1 was used, high demands were evident, as shown by high peak demands the following winter (Section 5.2.3.2). These control changes occurred in April 2001.

The documented operation and performance during March 2001 was typical for a heating dominated month during the first year of occupancy. The monthly utility bills indicate high energy use during the heating months for the first year of occupancy (March 2000-February 2001), as shown previously in Figure 2-3. Although we did not monitor the end uses for the first year, we expect EB-1 was the primary reason for high energy use during the first heating season.

During the month of June, the building was not fully cooled during the warmer periods. Figure 5-6 shows the small amount of cooling energy used during that month. This decrease in electrical load was because the HP-4 and HP-5 were not being used, as the building was mostly unoccupied during summer break. The console heat pump units were used in the occupied offices and sparingly in the unoccupied classrooms to maintain the unoccupied cooling set point. To approximate daily occupation of the auditorium and classrooms to verify the cooling system performance with occupancy, HP-4 and HP-5 were controlled on during weekdays to furnish conditioned outdoor air to the unoccupied zones during the day. This control change was scheduled for the remaining months of the cooling season to ensure that the classrooms and the auditorium followed typical summer occupancy patterns, as is evident by the increase in cooling energy consumption for July and August.

Figure 5-7 illustrates the annual distribution of electricity consumption by end use. 


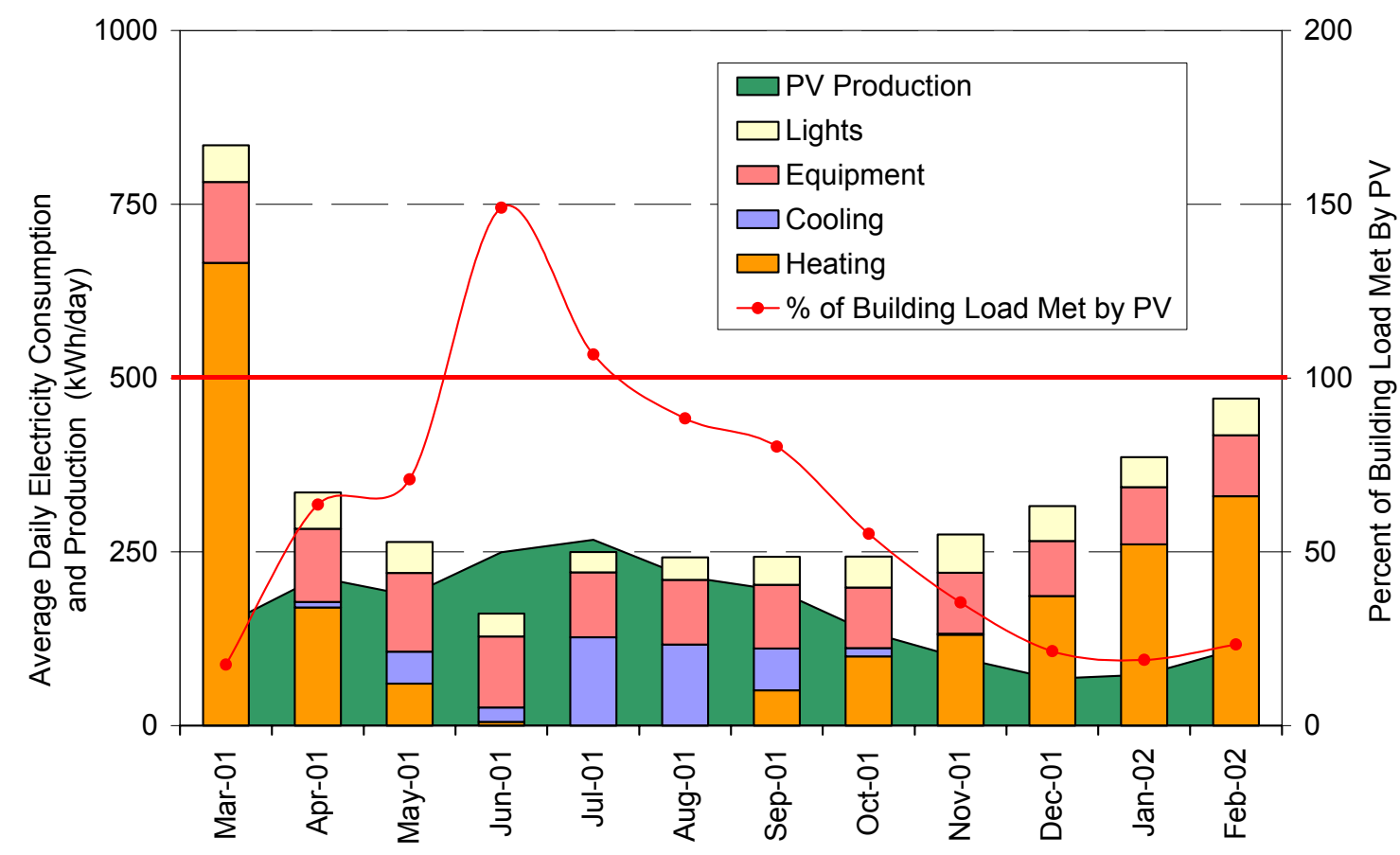

Figure 5-6 Average daily energy performance, March 1, 2001 through February 28, 2002

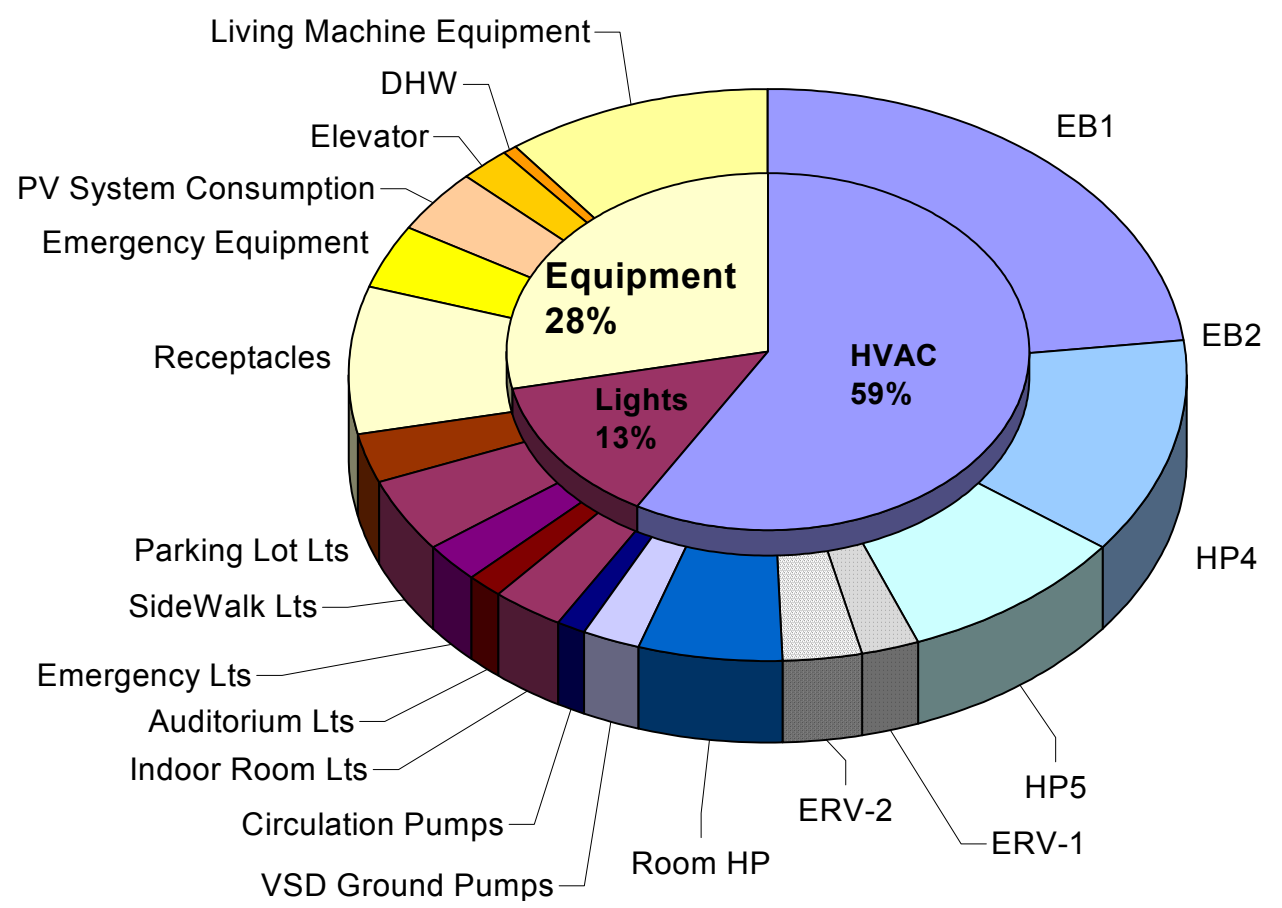

Figure 5-7 Energy consumption end use summary, March 1, 2001 through February 28, 2002

From March 1, 2001 through February 28, 2002, the Lewis Center consumed 122,139 kWh. HVAC accounted for $71,397 \mathrm{kWh}$, or $59 \%$ of the total consumed. As previously discussed, EB-1 was the largest 
HVAC end use because of large heating loads during the spring of 2001. The HP-5 backup boiler, EB-2, was not used during the evaluation period. Lighting end uses comprised $13 \%$ of total consumption $(16,093 \mathrm{kWh})$, of which 53\% was sidewalk and parking lot lights. This is discussed further in Section 6.4. The equipment end uses comprised $28 \%$ of total consumption $(34,649 \mathrm{kWh})$. wastewater treatmentrelated equipment loads were responsible for $36 \%$ of all the equipment end uses, or $10 \%$ of the total building energy consumption. The wastewater treatment loads do not include the heating requirements for this space. The largest wastewater treatment load was the exhaust fan that operated for a majority of the evaluation period. As most commercial buildings do not process their own wastewater, the wastewater treatment load is an additional load not typically seen in other commercial or educational buildings. This additional load will be discussed later in Section 6.1. For a discussion of the PV system consumption, refer to the PV system performance evaluation in Section 6.3. Appendix C provides a detailed, monthly summary of end use consumption from March 2001 through February 2002.

\subsubsection{Load Shape Profile Analysis}

To better understand the seasonal energy performance of the Lewis Center, daily consumption load shape profiles were considered (Figure 5-8). The consumption load shape profiles represent an average daily load profile for each season. The spring 2001 load shape is the average hourly consumption averaged over the months of March, April, and May. Summer 2001 includes the months of June, July, and August. Fall 2001 includes the months of September, October, and November. Winter 2001-2002 includes the months of December, January, and February.

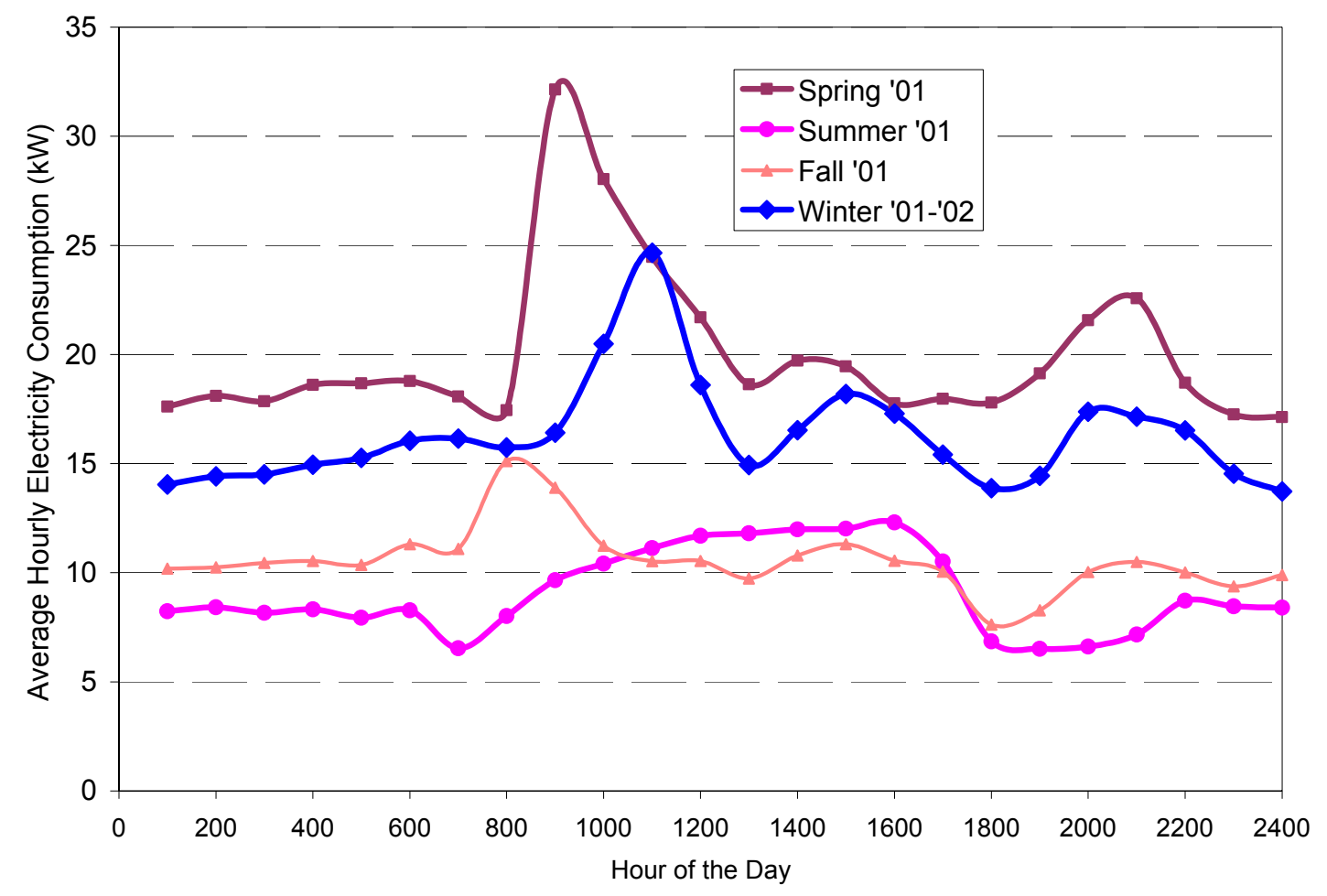

Figure 5-8 Total electricity consumption load shape by season (without PV production)

The effect of EB-1 is evident in the spring 2001 profile, as it was the primary cause for high daytime load shape and the large morning demand spike. The average winter load shape was significantly reduced as 
compared to spring 2001, although reduced EB-1 heating demands for the wastewater treatment were still present. This reduction was because of the control changes implemented in April 2001 shortly after the significant adverse impact of EB-1.

The nighttime base loads ranged from $8 \mathrm{~kW}$ to $17 \mathrm{~kW}$ over the year. High nighttime base loads can be a sign of excessive equipment operation and parasitic loads, which was the case for the consumption load shape seen in spring 2001. The nighttime average base load for EB-1 was $15 \mathrm{~kW}$, which resulted from the high heating demand of the wastewater treatment space and atrium. In general, the nighttime demand is $0.9 \mathrm{~kW}$ for the PV system isolation transformers (when the system is in standby mode), $2.5 \mathrm{~kW}$ for parking lot and sidewalk lights, $0.85 \mathrm{~kW}$ for the wastewater treatment exhaust fan, $0.5 \mathrm{~kW}$ of emergency equipment, $0.2 \mathrm{~kW}$ for the variable speed controller for the ground loop pumps, and $1.0 \mathrm{~kW}$ of plug loads. The winter 2001-2002 nighttime loads were higher than the summer or fall because of heating setback demands.

As most utilities peak in the summer causing strain on the infrastructure, it is important to look at summer load shapes. The hourly average peak consumption for a summer day was $12 \mathrm{~kW}$, which occurred in the late afternoon when the air conditioning loads were greatest. Even when the building operators controlled the building to be fully conditioned (simulating occupancy), the summer demands were significantly less than the winter heating loads. The small morning peak during the fall load shape was caused by occasional heating by EB-1 during warm-up periods.

When the building consumption seasonal load profile was combined with the PV production load profile, the net use profile shown in Figure 5-9 was created.

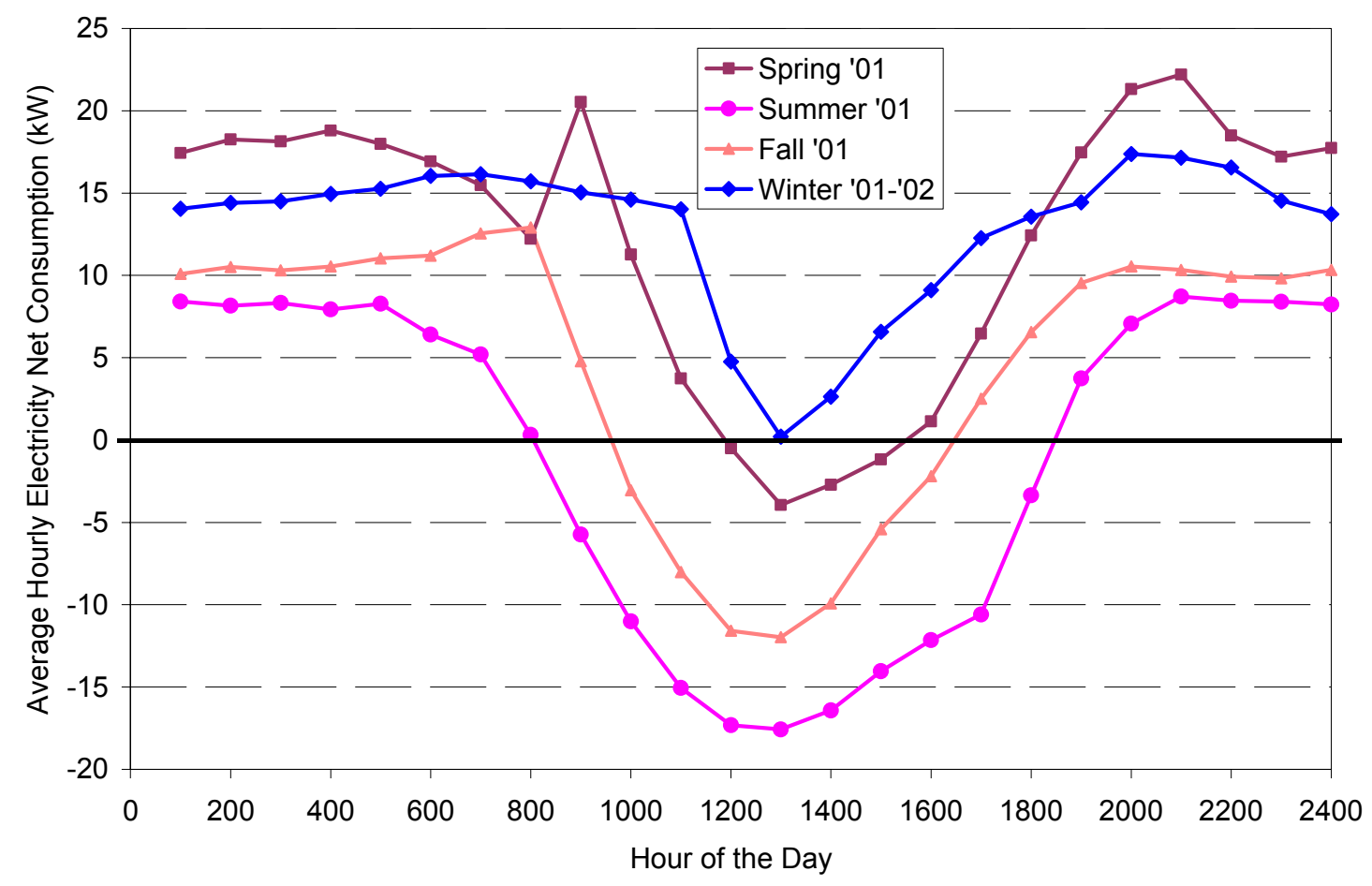

Figure 5-9 Daily average net electricity consumption load shape by season, with PV production

When the net use load profile was negative, the PV system produced more electricity than the building used, energy that was then exported back to the grid. For every season, on average (except winter 20012002), the building exported PV energy during part of the day. For the summer months when PV 
generation was the highest and the consumption the lowest, the building, on average, exported electricity from 8 a.m. to 6 p.m. From the utility perspective, the building was a net positive during daylight hours in the summertime and provided power when it is most needed by the grid. Again, the influence of EB-1 was evident during the morning warm-up for the spring months. More analysis of the PV system performance is included in Section 6.3.

\subsubsection{Demand and Energy Cost Analysis}

The load shape analysis showed that not only did the operation of EB-1 increase the energy loads, but it also created very high utility charges because of the demand. With a utility rate structure of $\$ 0.023 / \mathrm{kWh}$ consumption rate, $\$ 0.026 / \mathrm{kWh}$ distribution rate, and $\$ 8.68 / \mathrm{kVA}$ demand rate at a $15-\mathrm{min}$ demand ratchet, the electric utility bills were highly influenced by the demand charges. The demand rate is based on the peak monthly consumption over a fixed 15-min period. The monthly electricity charges from March 2001 through February 2002 are shown in Figure 5-10. For October 2001, when heating was required from the $112-\mathrm{kW}$ single stage EB-1, the average virtual rate for electricity was $\$ 0.25 / \mathrm{kWh}$. Even with consumption offset from the PV production, the annual operational energy costs were $\$ 1.17 / \mathrm{ft}^{2}$ $\left(\$ 12.59 / \mathrm{m}^{2}\right)$ from March 2001 through February 2002. The Lewis Center annual energy cost is higher than the average educational building as documented by the EIA in 1999. For the second year of operation, the PV system did not significantly reduce the Lewis Center energy costs. The Lewis Center did not receive credit for PV energy exported back to the grid, nor did the PV system dramatically reduce the demand. Without a net metering agreement, the Lewis Center exported 28,879 $\mathrm{kWh}(103,964 \mathrm{MJ})$ without financial credit from the utility. The second year utility bills would have been reduced by $\$ 1,415$ with a net metering agreement and an energy and distribution rate of $\$ 0.049 / \mathrm{kWh}$. The issue of uncredited power exports is discussed further in Section 6.3.2.

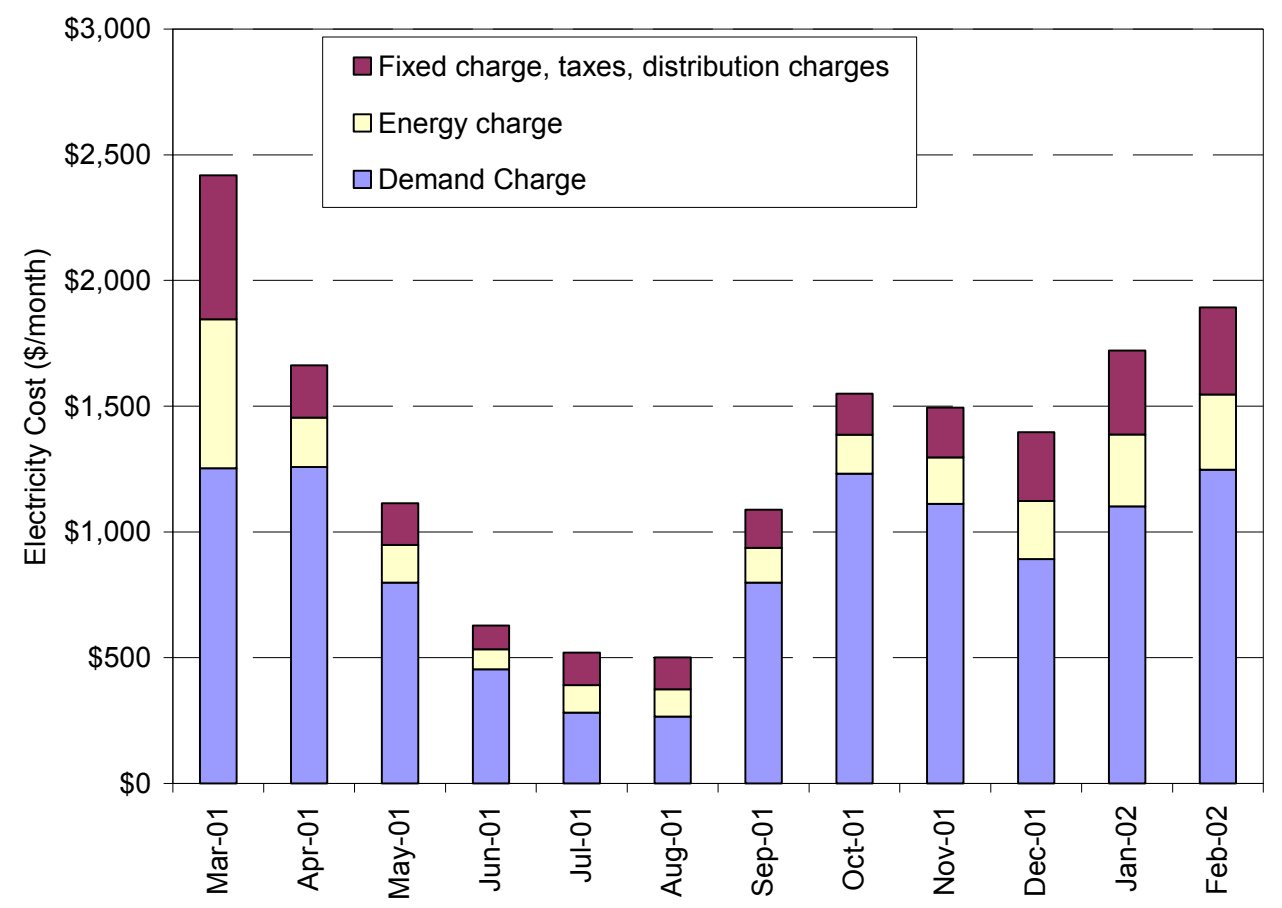

Figure 5-10 Monthly energy cost by charge type, March 2001-February 2002

As Figure 5-10 shows, demand charges were the primary reason for the high electricity charges. When EB-1 operated at $112 \mathrm{~kW}$ for 15 minutes, the demand charges of $\$ 8.59 / \mathrm{kW}$ resulted in high utility bills. The monthly demand charge for operating this unit for 15 minutes or more was $\$ 962$. 
Figure 5-11 shows the monthly peak demand. The demand data in this graph represent the maximum net building energy consumption (including PV production) averaged over $15 \mathrm{~min}$. The spring peak demand of $142 \mathrm{~kW}$ occurred on March 5, 2001. The summer peak demand of $45 \mathrm{~kW}$ occurred on June 4, 2001 at 4:00 a.m. This peak occurred during a cool night when EB-1 heating was required. The peak demand for the winter, fall, and spring seasons occurred at 9:00 a.m. when EB-1 was required for morning warm-up periods. The control changes made in April 2001 reduced the energy consumption of the hydronic system, but did not reduce the peak demands. See Section 5.2.4 for a discussion of the energy savings. It is also interesting to note that this commercial building has peak energy and power demands in the winter, not in the summer.

Figure 5-11 also demonstrates that the PV system did not significantly reduce peak electrical demand. For the months of July and August, the peak demand would have been $10 \mathrm{~kW}$ greater without a $60 \mathrm{~kW}$ PV system. The peak demand for these months was reduced because the peak consumption was coincident with PV production. For the other months of the year, the peak demand occurred when no PV production was present.

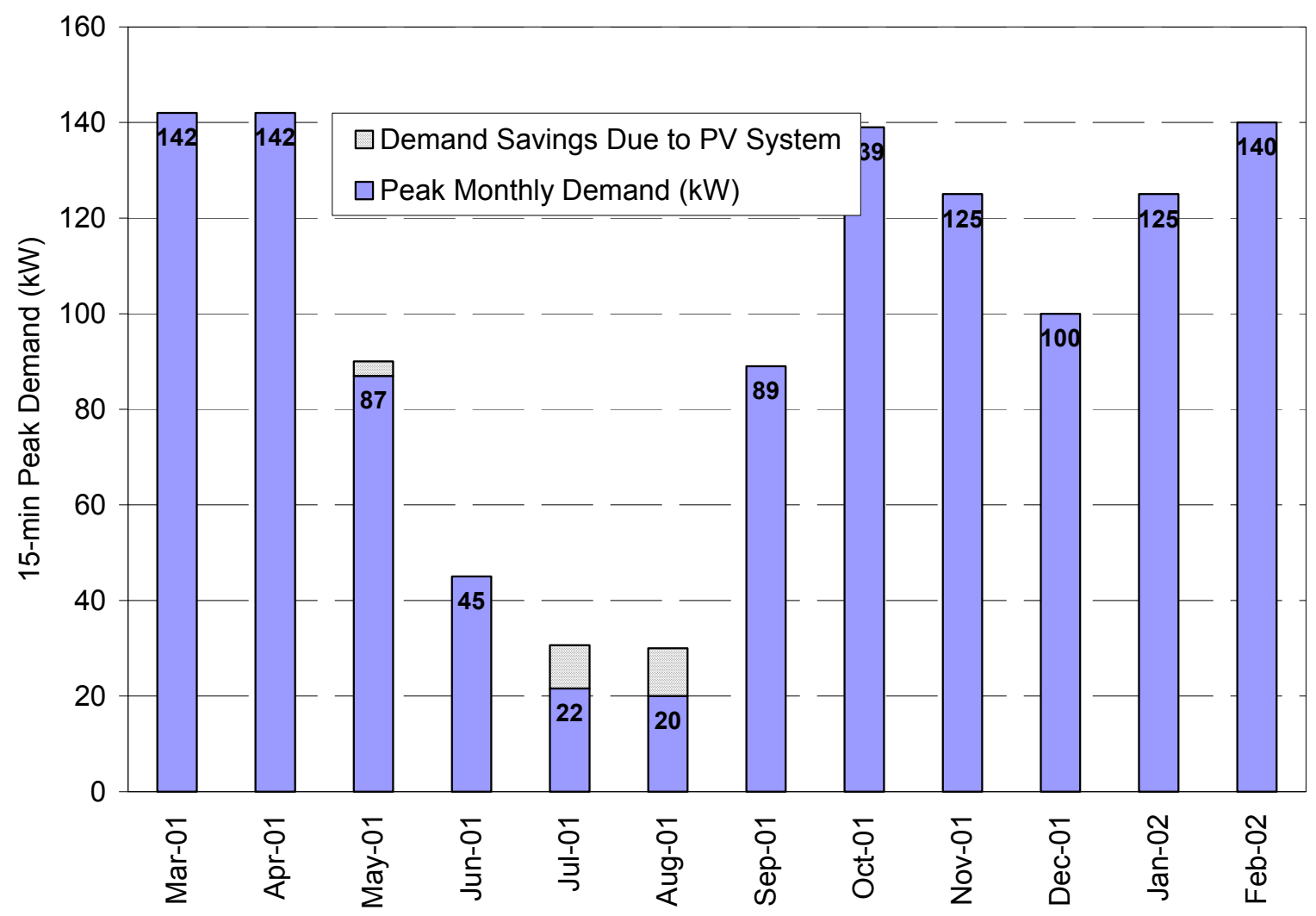

Figure 5-11 Peak 15-min demand by month (includes PV production)

Further analysis of the 15-min monthly demand resulted in identifying the primary reasons for the peak demand during the cooling and heating seasons. The 15-min cooling season peak demand occurred during a peak cooling day when mid-afternoon clouds reduced PV production. The cooling load end use components, PV production, and resulting purchased electricity (net use) for the peak day in August 2001, 
are shown in Figure 5-12. The peak in July 2001 was due to similar peak cooling loads and coincident minimal PV production. In Figure 5-12 and Figure 5-13, the areas of each end use are additive, so that the total consumption is represented by total area of the end uses. The PV production is shown below the $\mathrm{x}$-axis as a negative consumption. The net use is negative when the Lewis Center produces more energy than was used.

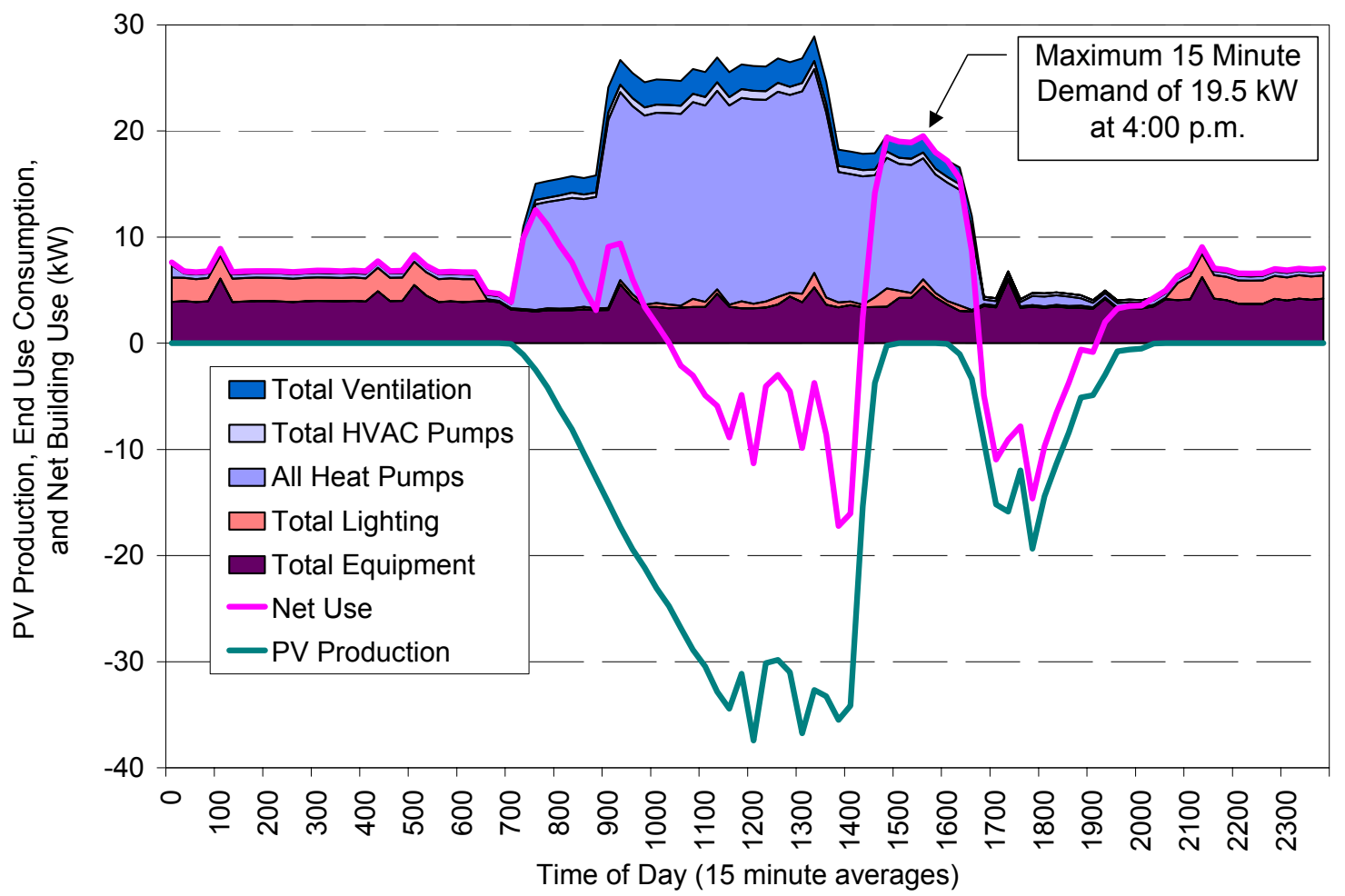

Figure 5-12 Peak August utility demand, PV production, and end use (August 9, 2001)

The 15-min heating season peak demand occurred during a high heating load day when the 112-kW EB-1 operated during the morning warm-up period, as shown in Figure 5-13. PV production did not offset this peak demand at 9:00 a.m. Although control changes made in April of 2001 reduced the energy use of EB-1, they did not eliminate the peak demands of the boiler.

Significant cost savings could be realized by sequencing the heating equipment to meet the heating loads and operate within demand limit constraints. This may use slightly more energy, but significantly even out the loads. The building could be preheated when PV demand is available maximizing the benefit of this system. Similar benefits could be achieved during the summer by precooling the building when extra onsite generation is available. The analysis also shows replacing EB-1 with more efficient heat pumps would be beneficial by reducing demand charges. See Section 5.2.4 for a discussion of this replacement. 


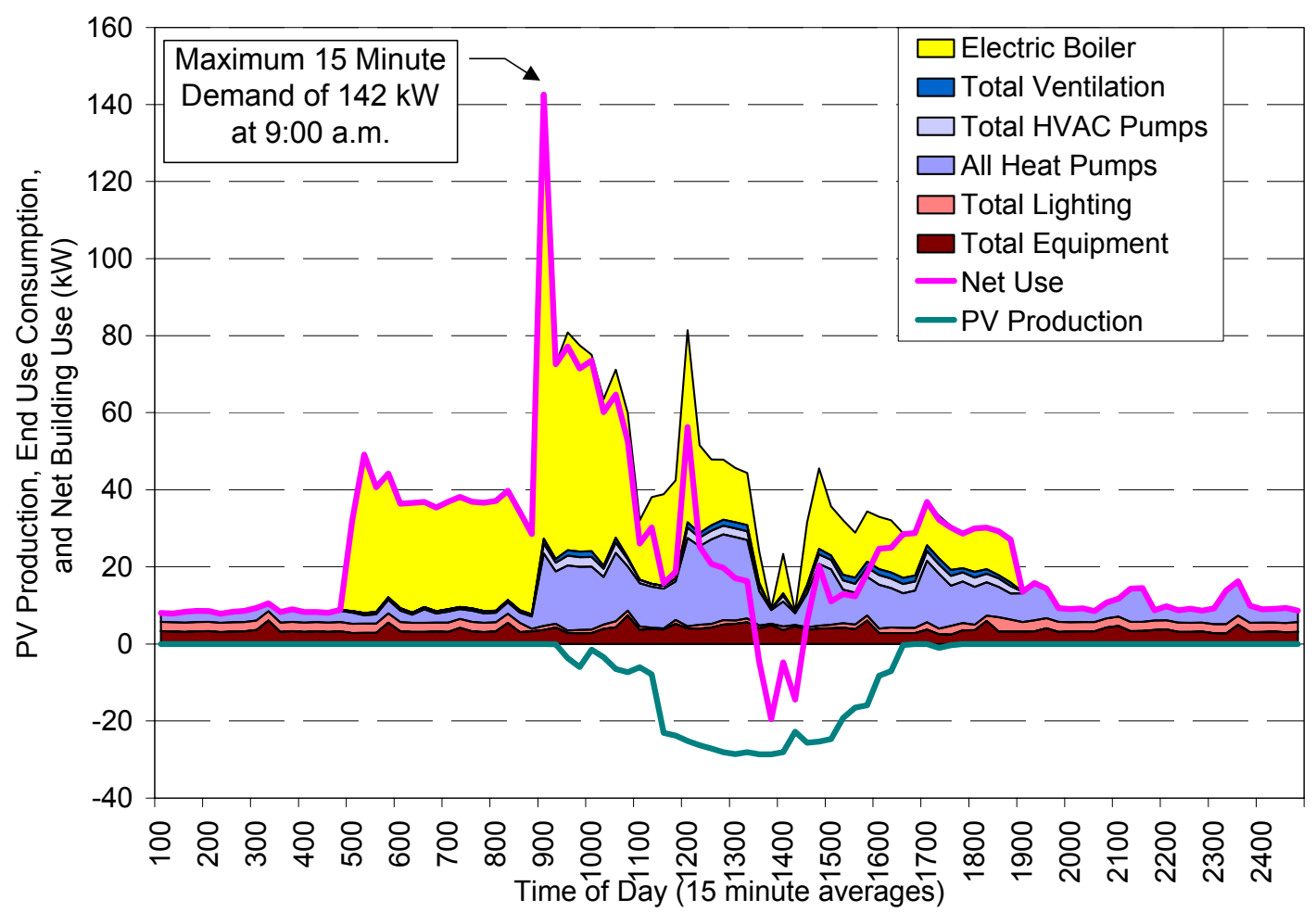

Figure 5-13 Peak heating season utility demand, PV production, and end use (Jan. 4, 2002)

\subsubsection{Measured Equipment Performance}

The total annual equipment consumption was $34,649 \mathrm{kWh}(124,740 \mathrm{MJ})$, or $7.5 \mathrm{kBtu} / \mathrm{ft}^{2} \cdot \mathrm{yr}$ $\left(85 \mathrm{MJ} / \mathrm{m}^{2} \cdot \mathrm{yr}\right)$. This translates to $0.29 \mathrm{~W} / \mathrm{ft}^{2}\left(3.1 \mathrm{~W} / \mathrm{m}^{2}\right)$. The total equipment category includes all nonemergency plug loads, plug loads on the emergency circuits, elevator, DHW, nighttime PV transformer standby losses, and wastewater treatment equipment. The equipment loads of typical educational buildings do not include the specialized types of loads such as PV transformers and wastewater treatment process loads. According to the EIA, plug loads in educational buildings consumed 57 trillion Btu $(60,000 \mathrm{TJ})$ of site electricity in 1999 at an energy consumption intensity of $6.6 \mathrm{kBtu} / \mathrm{ft}^{2} \cdot \mathrm{yr}$ $\left(75 \mathrm{MJ} / \mathrm{m}^{2} \cdot \mathrm{yr}\right)$ (EIA 1999). The measured equipment load energy consumption intensity at the Lewis Center, excluding the PV transformers, and wastewater treatment related equipment, was $4.5 \mathrm{kBtu} / \mathrm{ft}^{2} \cdot \mathrm{yr}$ $\left(51 \mathrm{MJ} / \mathrm{m}^{2} \cdot \mathrm{yr}\right)$. Figure 5-14 depicts the daily equipment load shape profile, averaged over the evaluation period. 
Emergency Plug Loads $\square$ Elevator $\square$ DHW $\square$ Plug Loads $\square$ LM Equipment $\square$ PV Transformers

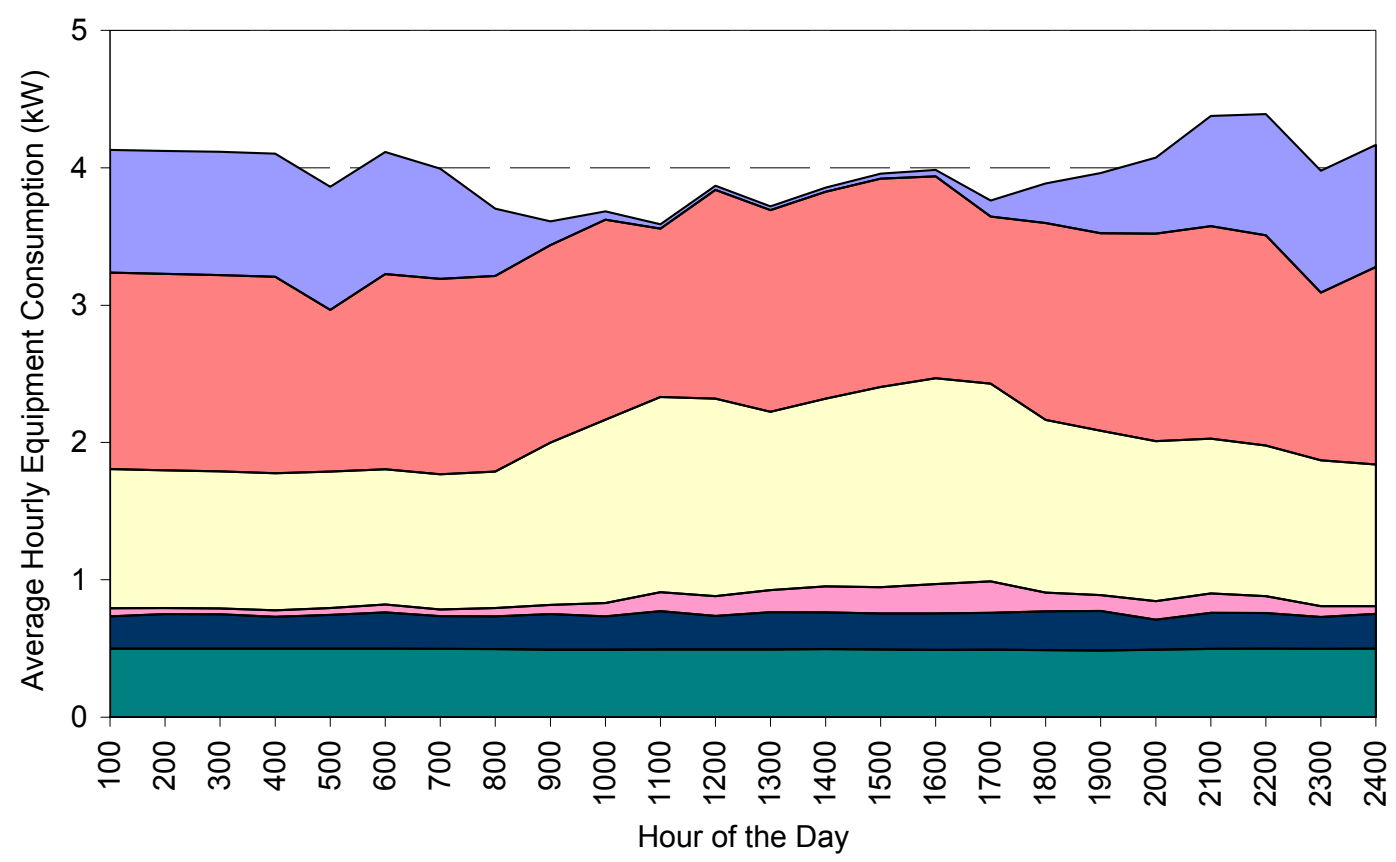

Figure 5-14 Annual equipment consumption load shape

The total equipment load shape includes all equipment end uses. On average, there were $2.4 \mathrm{~kW}$ of plug, emergency equipment, DHW, and elevator loads during occupied times and $1.8 \mathrm{~kW}$ during unoccupied times. Plug loads, emergency equipment, DHW, and elevator loads are typical equipment loads in educational buildings. The plug loads, emergency equipment, DHW, and elevator loads (or typical equipment loads) energy use intensity over the evaluation period was $0.15 \mathrm{~W} / \mathrm{ft}^{2}\left(1.6 \mathrm{~W} / \mathrm{m}^{2}\right)$. Figure $5-16$ shows all the equipment loads normalized by the building floor area. The equipment energy use intensity is averaged over all spaces at the Lewis Center, including the atrium, which has a minimal equipment load. An indication of the nightly typical equipment loads can be quantified by the daily power peak computed as a daily average divided by the daily power minimum. The occupied-to-unoccupied plug load ratio was 1.4 , with $0.13 \mathrm{~W} / \mathrm{ft}^{2}\left(1.4 \mathrm{~W} / \mathrm{m}^{2}\right)$ of typical equipment load use intensity during unoccupied hours and $0.18 \mathrm{~W} / \mathrm{ft}^{2}\left(1.94 \mathrm{~W} / \mathrm{m}^{2}\right)$ during occupied hours. This ratio can indicate excessive consumption of plug loads during unoccupied periods. At the Lewis Center, however, both unoccupied and occupied typical equipment load consumption was not excessive as compared to other Lewis Center loads. These equipment load shape profiles did not vary significantly by season. The PV transformer's profile had the largest seasonal variance, as the consumption of the transformers was directly related to the length of stand-by operation. The PV system stand-by operation was longer during winter nights and shorter during summer nights. 


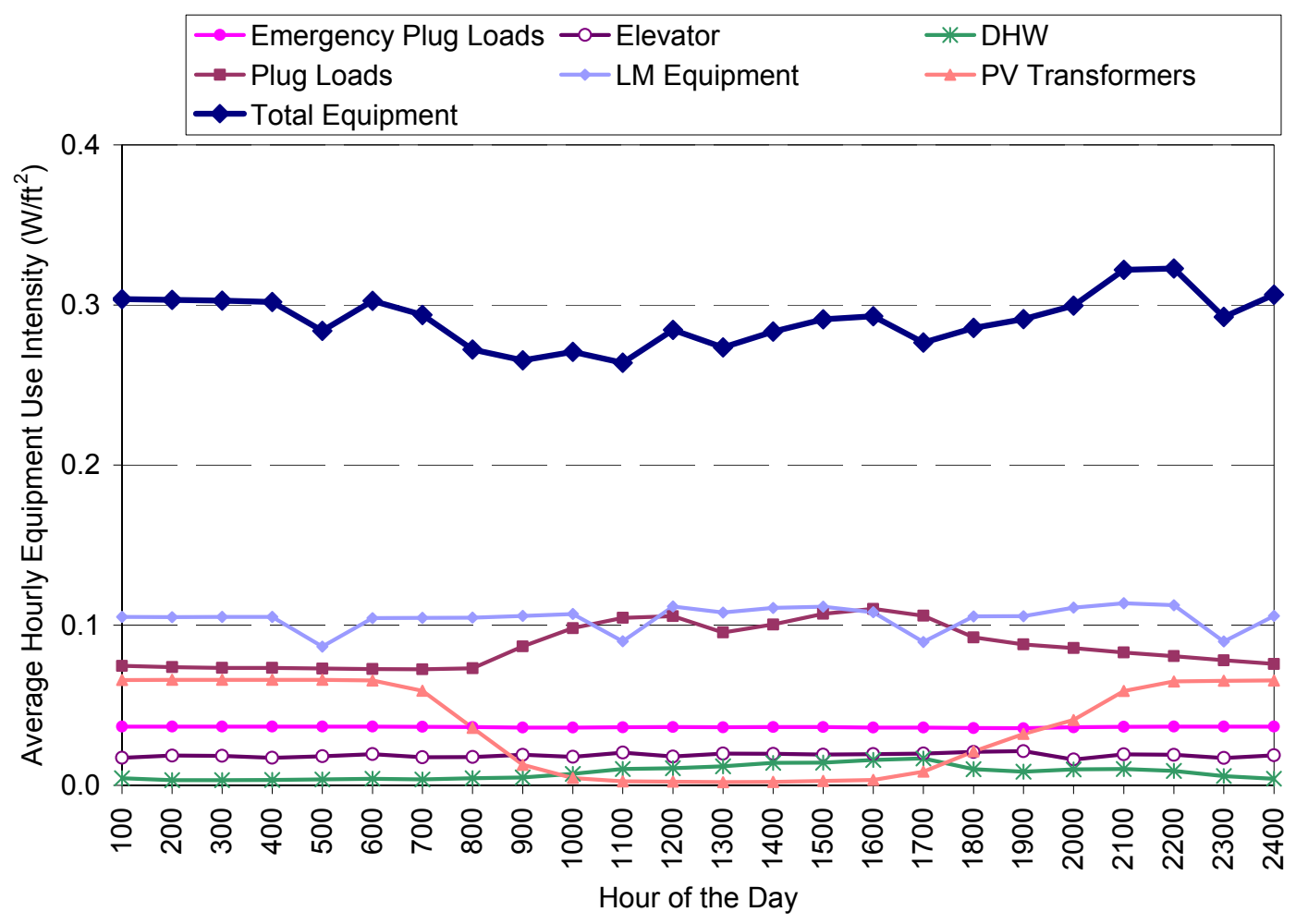

Figure 5-15 Annual equipment use intensity load shape

\subsubsection{March 2002-February 2003 Measured Data Analysis}

The summary metrics that result from the whole-building analysis of the third year of occupancy (March 2002 through February 2003) include annual energy cost intensity, measured site energy use intensity, measured PV production, measured net site use, and measured source use intensity. Additional analysis of measured end use data and utility bills are provided for the third year to study changes made during the evaluation period. Figure 5-16 summarizes the monthly energy performance over two years of detailed energy monitoring. The timing of significant operational and equipment changes, as discussed below, are also shown. Appendix C provides a detailed, monthly summary of end use consumption from March 2002 through February 2003. 


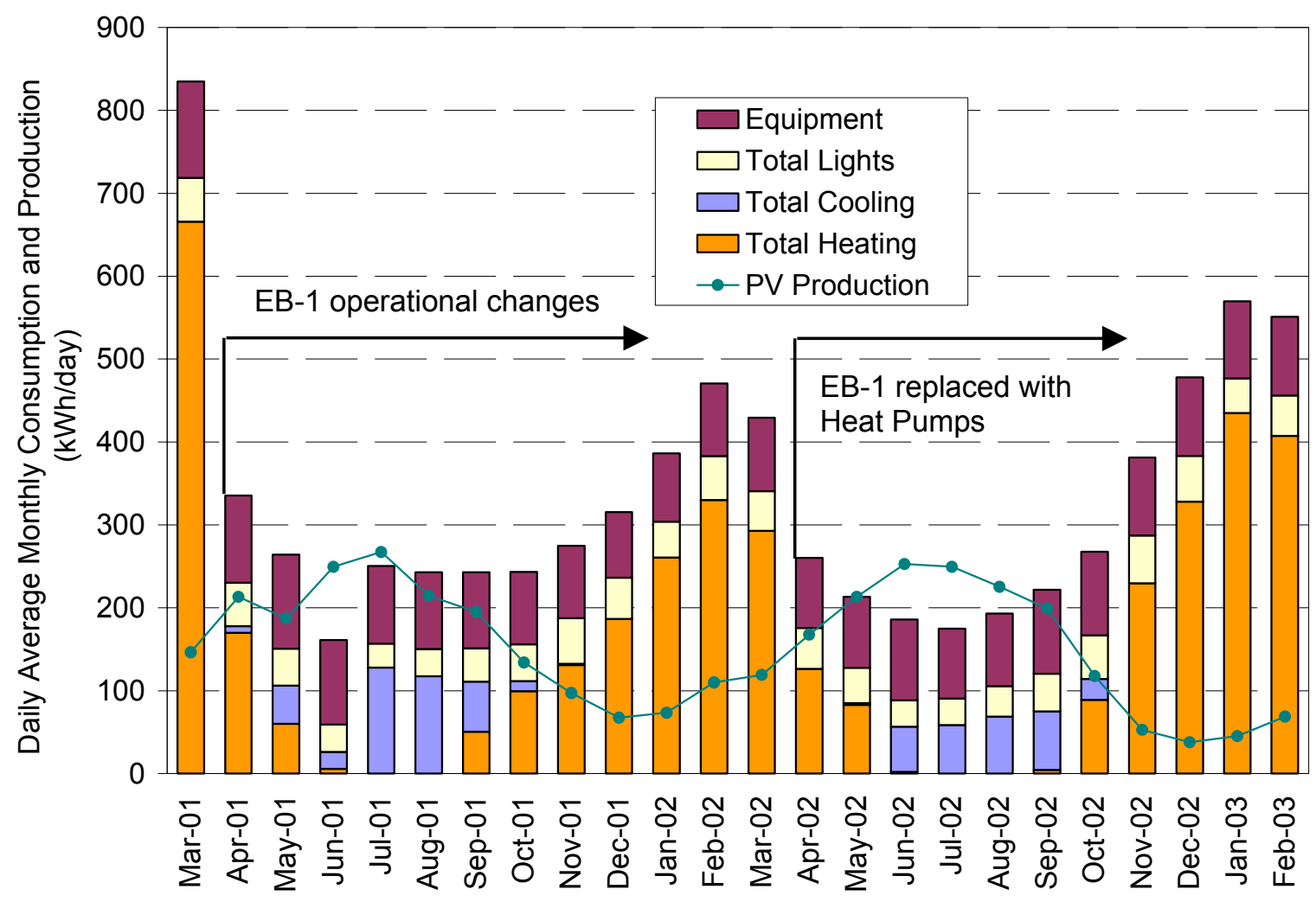

Figure 5-16 Daily average energy use and production, March 2001 through February 2003

At a gross floor area of $13,600 \mathrm{ft}^{2}\left(1260 \mathrm{~m}^{2}\right)$, the third-year site consumption energy intensity was $29.8 \mathrm{kBtu} / \mathrm{ft}^{2} \cdot \mathrm{yr}\left(338 \mathrm{MJ} / \mathrm{m}^{2} \cdot \mathrm{yr}\right)$. The PV system produced $53,540.3 \mathrm{kWh}(192.7 \mathrm{GJ})$, or $13.4 \mathrm{kBtu} / \mathrm{ft}^{2} \cdot \mathrm{yr}$ $\left(152 \mathrm{MJ} / \mathrm{m}^{2} \cdot \mathrm{yr}\right)$. On an annual basis, the PV system produced $45 \%$ of the electricity consumed in the Lewis Center. The net annual site consumption intensity, including PV production, was $16.4 \mathrm{kBtu} / \mathrm{ft}^{2} \cdot \mathrm{yr}$ $\left(186 \mathrm{MJ} / \mathrm{m}^{2} \cdot \mathrm{yr}\right)$. This net site consumption resulted in a source energy intensity of $53.0 \mathrm{kBtu} / \mathrm{ft}^{2} \cdot \mathrm{yr}$ $\left(602 \mathrm{MJ} / \mathrm{m}^{2} \cdot \mathrm{yr}\right)$.

The second and third year measured results, presented in Table 5-5, are dependent on operational characteristics and the weather for each year. The annual variability makes it difficult to understand yearto-year performance. This is especially the case with highly variable site weather. For the third year of occupancy, there were 6,277 heating degree days $\left(65^{\circ} \mathrm{F}\right.$ base), while the second year had only 4,967 heating degree days $\left(65^{\circ} \mathrm{F}\right.$ base $)$. 
Table 5-5 Measured Whole-building Results, Second and Third Year of Operation

\begin{tabular}{|c|c|c|c|c|c|c|}
\hline & $\begin{array}{c}\text { Measured } \\
\text { Site Use } \\
\text { Intensity } \\
\mathrm{kBtu} / \mathrm{ft}^{2} \\
\left(\mathrm{MJ} / \mathrm{m}^{2}\right)\end{array}$ & $\begin{array}{c}\text { Measured PV } \\
\text { Production } \\
\text { Intensity } \\
\mathrm{kBtu} / \mathrm{ft}^{2} \\
\left(\mathrm{MJ} / \mathrm{m}^{2}\right)\end{array}$ & $\begin{array}{c}\text { Percent of } \\
\text { Building } \\
\text { Load Met By } \\
\mathbf{P V}\end{array}$ & $\begin{array}{c}\text { Measured Net } \\
\text { Site Use } \\
\text { Intensity } \\
\mathrm{kBtu} / \mathrm{ft}^{2} \\
\left(\mathrm{MJ} / \mathrm{m}^{2}\right)\end{array}$ & $\begin{array}{c}\text { Measured } \\
\text { Source Use } \\
\text { Intensity } \\
\mathrm{kBtu} / \mathrm{ft}^{2} \\
\left(\mathrm{MJ} / \mathrm{m}^{2}\right)\end{array}$ & $\begin{array}{c}\text { Energy Cost } \\
\text { Intensity } \\
\$ / \mathrm{ft}^{2} \\
\left(\$ / \mathrm{m}^{2}\right)\end{array}$ \\
\hline $\begin{array}{c}\text { March 2001 } \\
\text { through } \\
\text { February 2002 }\end{array}$ & $\begin{array}{c}30.6 \\
(348)\end{array}$ & $\begin{array}{c}14.9 \\
(169)\end{array}$ & $49 \%$ & 15.7 & 50.6 & 1.17 \\
\hline $\begin{array}{c}\text { March 2002 } \\
\text { through }\end{array}$ & 29.8 & 13.4 & $45 \%$ & $\begin{array}{c}16.4 \\
(575)\end{array}$ & $(12.59)$ \\
\hline February 2003 & $(338)$ & $(152)$ & $(186)$ & 53.0 & 0.85 \\
\hline
\end{tabular}

1. PV production normalized by building floor area for comparison to site use intensity

The reduced PV production for third year was due to $10 \%$ less solar availability over the year, combined with additional snowfall, as compared to the second year. The decrease in PV production is greater than the decrease in site energy use, resulting in greater source energy use and less load met by PV in the third year.

The third-year total heating consumption was slightly greater than the second year because of the colder winter. From March 2002 through February 2003, NREL confirmed the water-to water heat pump system was a more efficient system than the electric boiler system, as shown in Figure 5-17. At a specific average daily ambient temperature during the winter, the third-year daily HVAC energy consumption was less than the second year operation at the same ambient temperature. The simulation analysis in the following sections removes weather effects, allowing for a year-to-year comparison. The simulation analysis will also quantify the energy savings due to the new heat pump system.

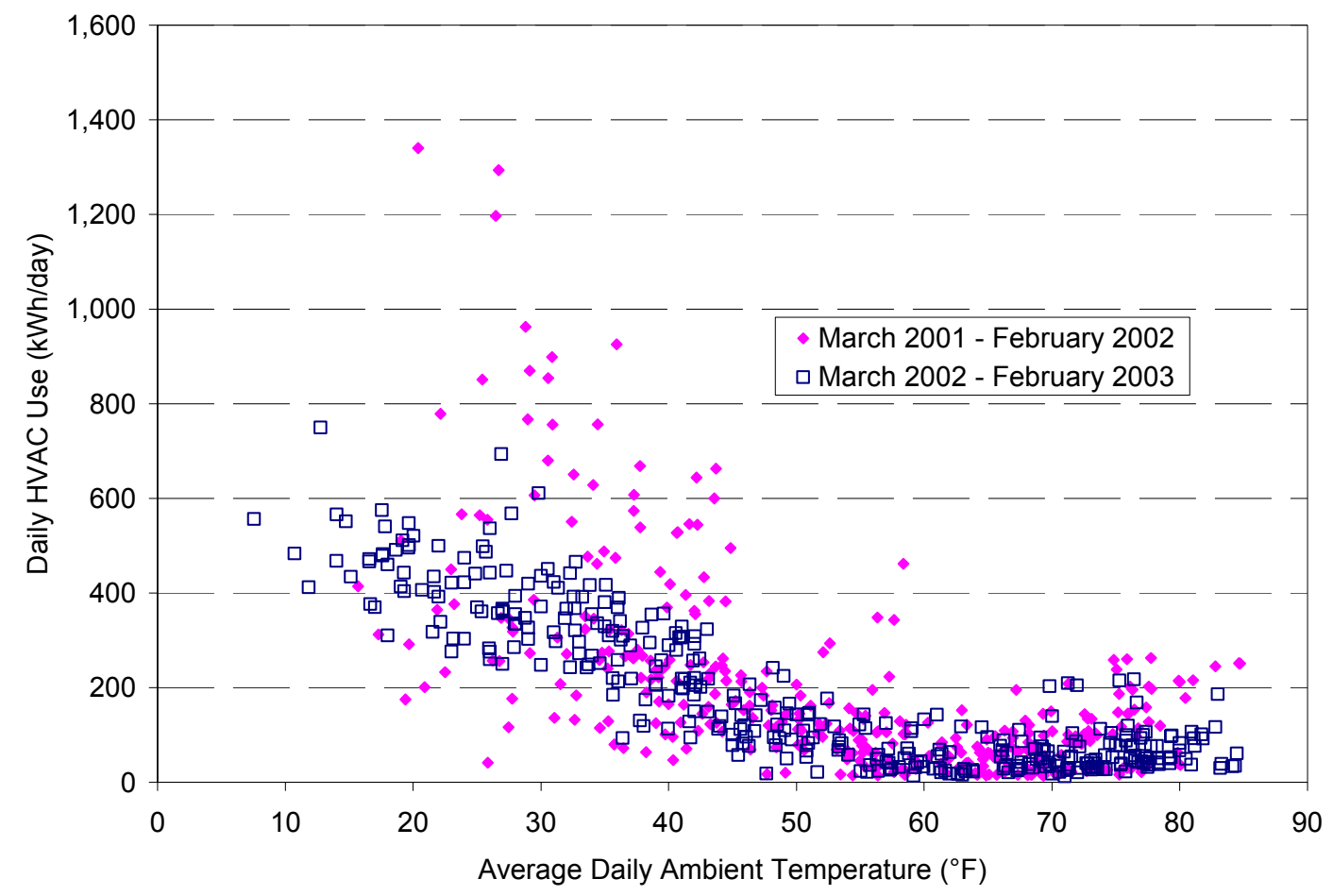

Figure 5-17 Daily HVAC energy use as a function of ambient temperature, second and third year of operation 
The Lewis Center is a heating dominated building, with HVAC responsible for 59\% of the total energy consumed in the building from March 2001 through February 2002. Controlling heating loads, therefore, offered the greatest potential for energy, demand, and cost savings. The first response for reducing heating loads was to reduce the demand on the EB-1. NREL identified this electric boiler to be the highest consuming end use during the first month (March 2001) of detailed energy monitoring. As a solution for reducing EB-1 energy use, the facility managers reduced the wastewater treatment set points and temporarily changed the heating source in the atrium to the more efficient HP-4. These changes and the EB-1 performance during March 2001 are discussed in detail in Section 5.2.3.1.

Figure 5-18 shows the energy use reduction of the electric boiler and HP-4 resulting in these operational changes. In March 2001, EB-1 used 14,490 kWh (52,161 MJ), and in March of 2002, 3,518 kWh (12,665 MJ). The monthly total HP-4 energy use increased from $455 \mathrm{kWh}$ to 3,163 kWh from March 2001 to March 2002. These operational changes made in April 2001 also helped to improve the overall energy performance of the Lewis Center during the following heating season.

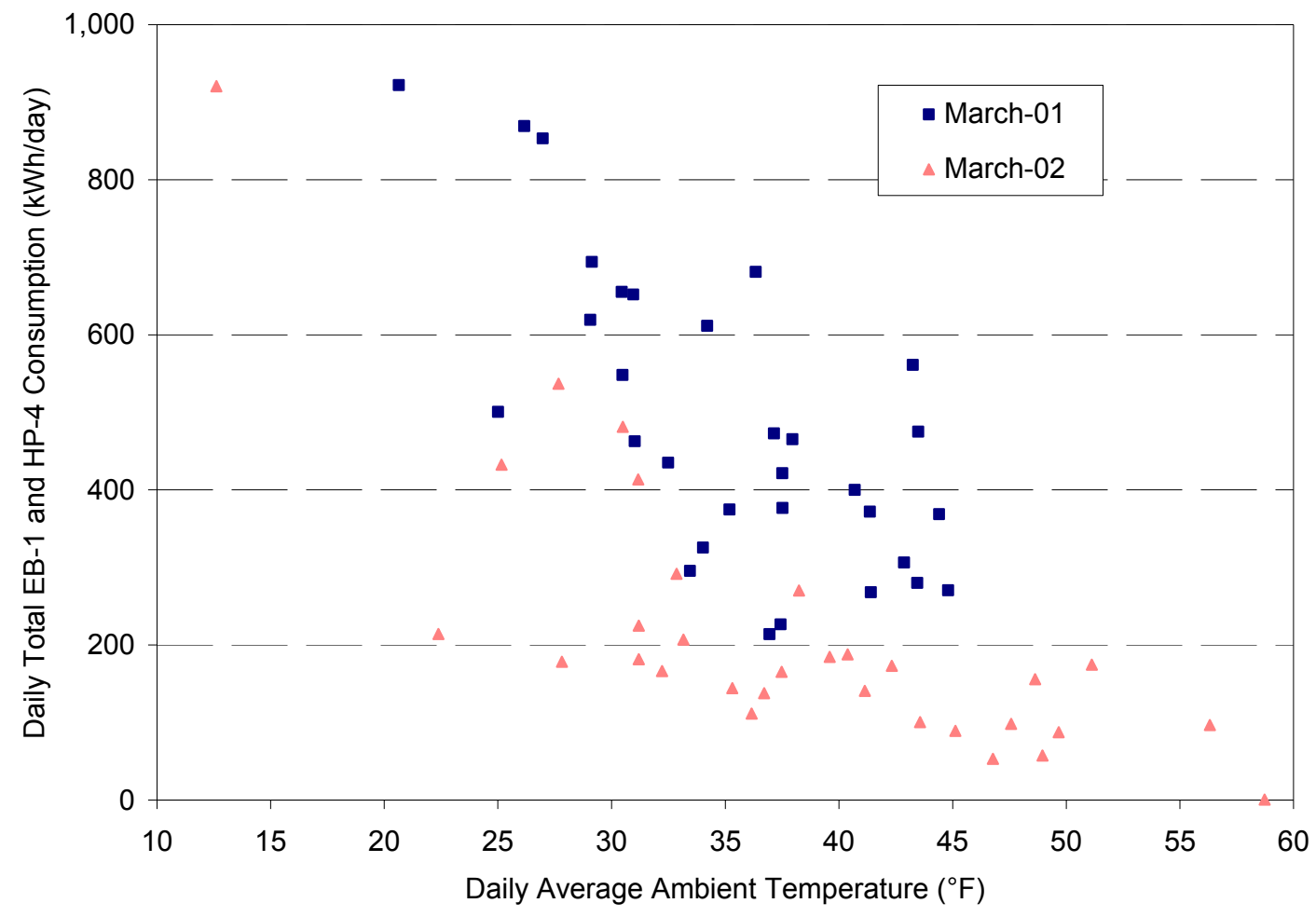

Figure 5-18 Daily EB-1 and HP-4 energy use as a function of ambient temperature, March 2001 and March 2002

As the operational changes made during the second year of operation were only a temporary solution, a permanent solution was implemented. Oberlin College decided to replace the hydronic electric boiler with two 8-ton $(28.2 \mathrm{~kW})$, extended range, ground source heat pumps. The hydronic system heat pumps were installed before the 2002-2003 heating season. These heat pumps supply hot water to the radiant floor in the atrium as well as to the other hydronic heating zones, as shown in the upgraded HVAC schematic in Figure 5-19. The original ground source system schematics are shown in Figure 4-15. 


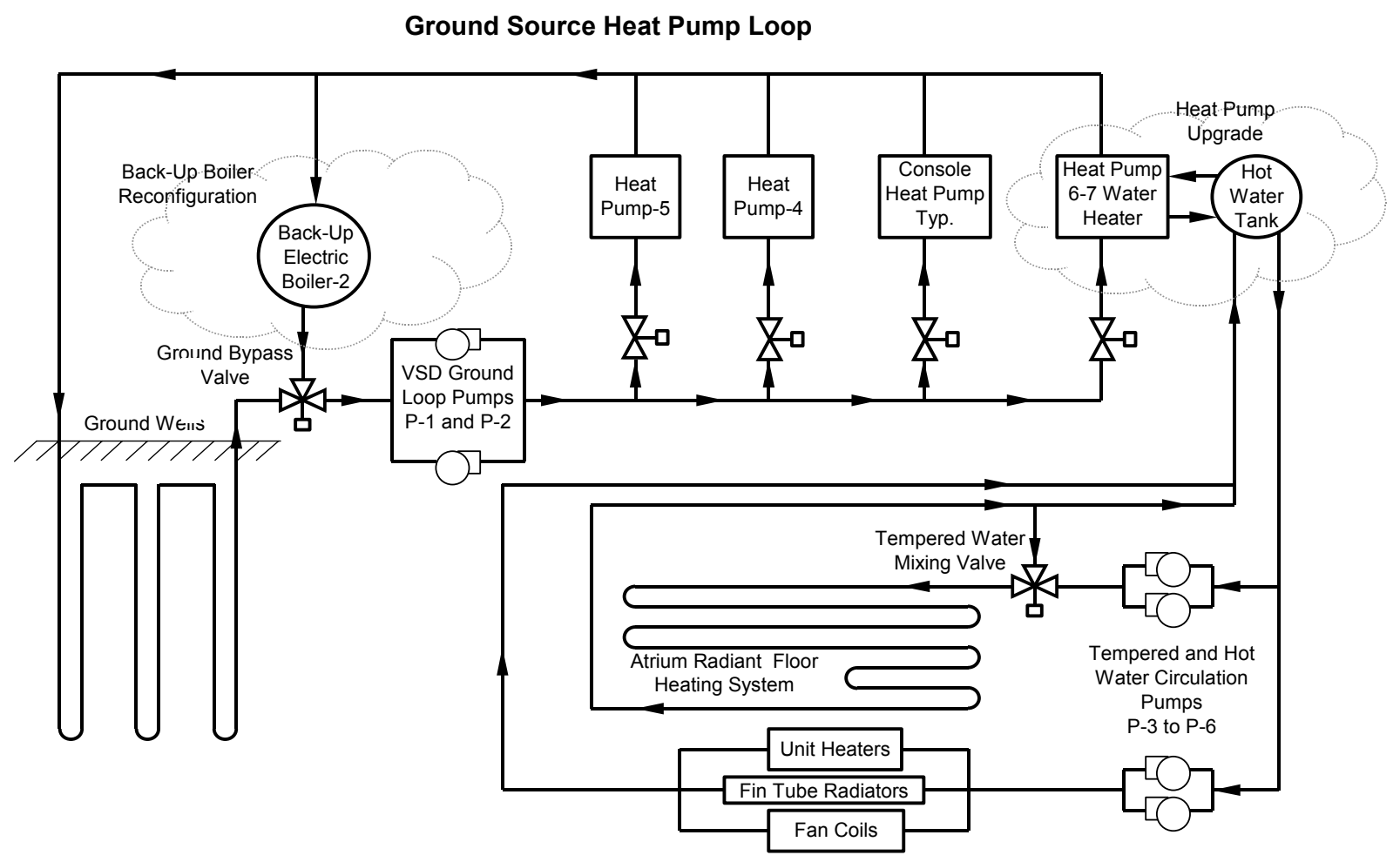

Figure 5-19 Upgraded hot-water and ground source heat pump piping schematic

This change increased the site heating efficiency of the hydronic heat supply and took advantage of the existing ground wells. The heating efficiency of these heat pumps is rated at a $4.1 \mathrm{COP}$ for $30^{\circ} \mathrm{F}\left(-1.1^{\circ} \mathrm{C}\right)$ entering water temperature. As the current ground well system was not sized for this additional capacity, the back-up electric boiler (EB-2) was left in place and reconfigured and controlled in stages to provide extra capacity for the ground source loop, if needed. This boiler was not used to provide capacity during the third year. The minimal measured consumption of this boiler was due to operation during installation and commissioning of the heat pump upgrade.

The measured annual equipment loads and lighting loads did not dramatically change from the second to third year. Emergency and classroom daylighting controls were upgraded during the second year of occupancy, as discussed in Section 6.4.2.5. The daylighting control upgrade was effective in reducing indoor lighting energy use, although the reduction was comparatively small to the total energy use in the building.

The energy cost intensity for the third year was $\$ 0.85 / \mathrm{ft}^{2}\left(\$ 9.15 / \mathrm{m}^{2}\right)$, down from $\$ 1.17 / \mathrm{ft}^{2}\left(\$ 12.59 / \mathrm{m}^{2}\right)$ the previous year. April and May 2002 had high demand charges associated with the installation and testing of the upgraded heat pumps and back-up electric boiler heating system. The demand charges for the third-year heating season were significantly reduced due to the removal of EB-1. In fact, after May 2002, the demand charges did not exceed $\$ 560$, while the previous heating season the demand changes ranged from $\$ 636.84$ to $\$ 1,247.58$. Third year energy charges were also reduced by a net-metering agreement implemented in April of 2002 with the local utility company. This allowed the Lewis Center to receive credit for any PV electricity exported back to the grid. As shown in Figure 5-20 the net consumption and resulting energy charge for the months of June through September of 2002 was $\$ 0$. 


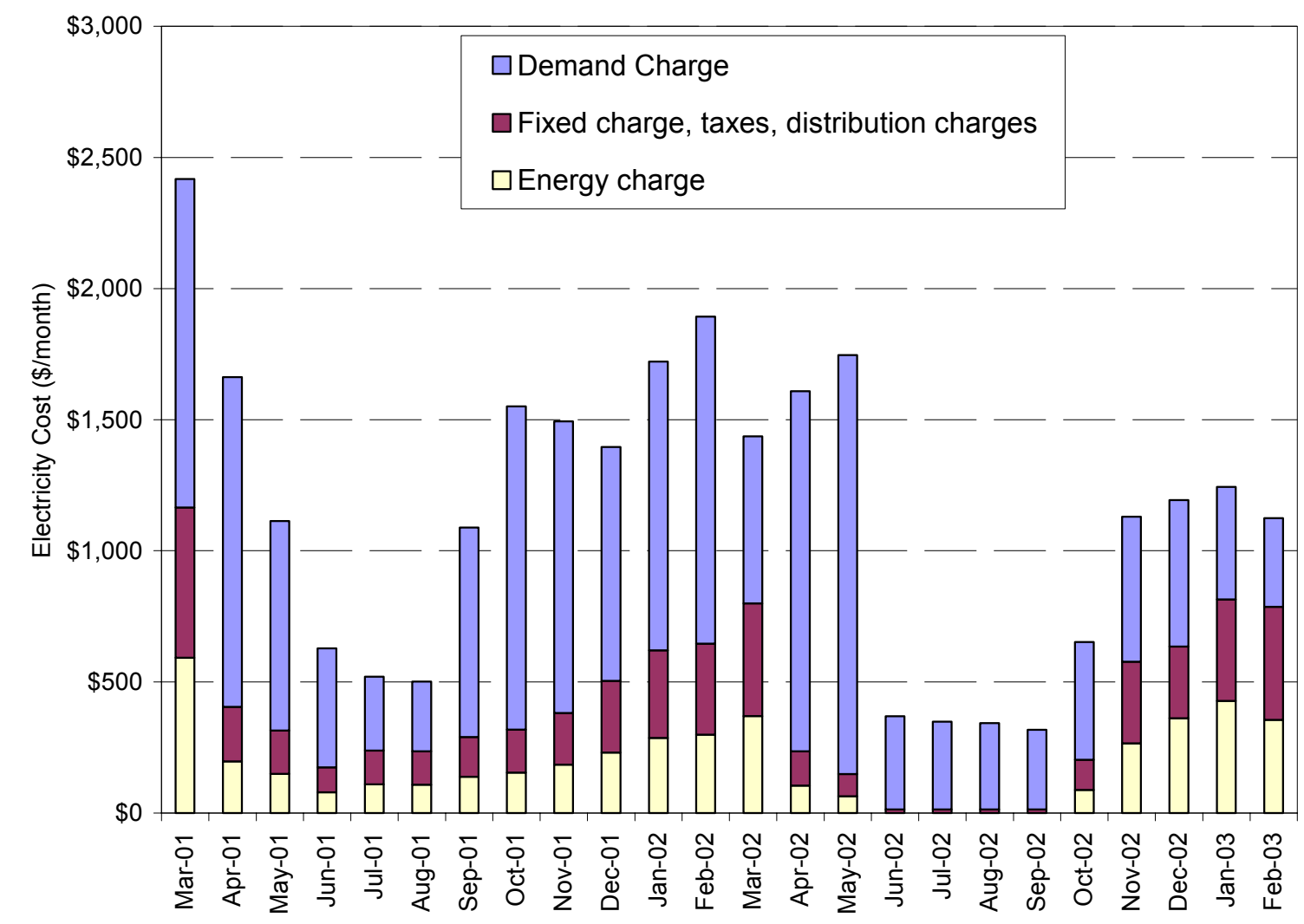

Figure 5-20 Monthly Utility Costs, March 2001 through February 2003

\subsection{Development of Building Energy Models}

The whole-building evaluation also includes modeling conventional and as-built buildings to calculate energy savings for typical weather years. A conventional building, or base case, was modeled to provide an energy benchmark. As-built models were modeled and compared to the base case to determine energy savings. The as-built models were calibrated against measured performance and driven by measured weather data. By comparing results of computer simulations, NREL reduced errors associated with comparing measured data with simulated data.

Performance indicators analyzed include site energy savings, source energy savings, and site cost energy savings. Calibrated as-built models and base cases were created for the second and third year of operation, with results provided for both years. The flow chart in Figure 5-2 shows how the measured data was used in the models and the process used to obtain the simulation results.

\subsubsection{DOE-2 Building Simulation Tool}

DOE-2 is a whole-building simulation program that can calculate hourly building heating and cooling loads, simulate the operation of primary and secondary HVAC systems, calculate lighting and equipment consumption, and perform economic analysis (York et al. 1980). The primary inputs required for DOE-2 to calculate the design and hourly space loads include building location and weather files; constructions for fenestration, walls, roof, and floors; the geometry, size and orientation of the building; and internal loads such as occupancy, lighting, and equipment. Characteristics, configurations, and controls of the HVAC components for the primary HVAC systems make up the input. The outputs from the simulation include a large list of hourly, monthly, and annual verification and summary reports. The validity and consistency of DOE-2 has been extensively researched and reported (Pasqualetto 1997). 


\subsubsection{Building Model Definitions}

NREL used four types of DOE-2 models to document the energy performance of the Lewis Center during the second and third year of operation and to adequately suggest solutions for identified building system problems. The models used were:

- As-built March 01-February 02 - This model was simulated with measured site weather data and typical meteorological year weather (TMY2) data (NREL 1995). It was calibrated using measured end uses and it represents various modes of building operation over the second-year monitoring period.

- As-built March 02-February 03 - This model was simulated with measured site weather data and TMY2 weather data. It was calibrated using measured end uses and it represents building operation over the third-year monitoring period.

- Base case - This model represents a conventional building that meets American Society of Heating, Refrigerating, and Air-Conditioning Engineers (ASHRAE) Standard 90.1-2001. This code-compliant Base-case model established a benchmark to compare and quantify the energy performance of as-built models.

- Optimized - This is an optimized model that included solutions for identified building system problems and provided a potential energy performance objective for a typical weather year. This model also provides an estimate of energy savings possible through current and future changes. NREL used the Base case modeled with As-built March 02-February 03 schedules for benchmarking purposes. The modeled recommendations are discussed in Section 7.

\subsubsection{Weather Analysis}

DOE-2 uses hourly weather data for building energy simulations. For the Base-case simulation, a TMY2 data weather file from Cleveland, Ohio, was used. During the model calibration process, as discussed in the next section, it becomes important to represent the actual environmental conditions that resulted in the measured energy performance. The large differences during the second year of occupancy between TMY2 and actual measured heating degree days (HDD) and cooling degree days (CDD), as described below, justified creating a new weather file. This DOE-2 weather file, in TMY2 format, was created based on measured meteorological site conditions. The measured weather file was used in simulating the as-built energy performance of the building during the calibration process.

The hourly measurements of the local environmental conditions enabled the comparison between the second year measured HDD, measured CDD, average outdoor temperatures, and levels of solar radiation to those from the weather file used in the DOE-2 simulation (TMY2 for Cleveland, Ohio). This comparison was made each month and is summarized in Table 5-6. 
Table 5-6 TMY2 and Second Year Measured Outdoor Environmental Conditions

\begin{tabular}{|c|c|c|c|c|c|c|c|c|}
\hline \multirow[t]{2}{*}{ Month } & \multicolumn{2}{|c|}{$\begin{array}{c}\text { HDD } \\
\left(65^{\circ} \mathrm{F} \text { base }\right)\end{array}$} & \multicolumn{2}{|c|}{$\begin{array}{c}\text { CDD } \\
\left(65^{\circ} \mathrm{F} \text { base }\right)\end{array}$} & \multicolumn{2}{|c|}{$\begin{array}{c}\text { Average Monthly } \\
\text { Temperature } \\
\left({ }^{\circ} \mathrm{F}\right)\end{array}$} & \multicolumn{2}{|c|}{$\begin{array}{l}\text { Average Horizontal Solar } \\
\text { Radiation } \\
\text { (Btu/ft } / \text { day) }\end{array}$} \\
\hline & TMY2 & Measured & TMY2 & Measured & TMY2 & Measured & TMY2 & Measured \\
\hline March 01 & 854.0 & 920.5 & 0.0 & 0.0 & 37.5 & 35.3 & 1075.2 & 1050.7 \\
\hline April 01 & 513.5 & 385.0 & 9.0 & 27.0 & 48.5 & 53.1 & 1481.5 & 1572.6 \\
\hline May 01 & 234.5 & 155.0 & 27.5 & 37.5 & 59.2 & 61.4 & 1832.2 & 1563.2 \\
\hline June 01 & 47.0 & 51.0 & 153.0 & 180.5 & 69.3 & 69.3 & 1962.4 & 1963.5 \\
\hline July 01 & 12.0 & 6.0 & 204.0 & 247.0 & 72.0 & 73.1 & 1908.9 & 2038.7 \\
\hline August 01 & 31.5 & 0.0 & 129.0 & 261.5 & 68.5 & 73.3 & 1689.6 & 1596.4 \\
\hline September 01 & 128.5 & 79.5 & 78.5 & 74.0 & 63.4 & 64.3 & 1331.4 & 1308.1 \\
\hline October 01 & 365.0 & 311.5 & 15.0 & 16.0 & 53.8 & 55.2 & 926.0 & 841.0 \\
\hline November 01 & 669.0 & 453.5 & 1.0 & 0.0 & 42.7 & 49.6 & 503.5 & 590.1 \\
\hline December 01 & 1018.0 & 850.0 & 0.0 & 0.5 & 32.2 & 37.5 & 391.2 & 406.9 \\
\hline January 02 & 1191.5 & 925.0 & 0.0 & 0.0 & 26.7 & 34.8 & 520.9 & 476.6 \\
\hline February 02 & 1043.0 & 829.5 & 0.0 & 0.0 & 28.2 & 35.2 & 766.8 & 737.6 \\
\hline Year & 6107.5 & 4966.5 & 617.0 & 844.0 & 50.3 & 53.6 & 1201.4 & 1180.4 \\
\hline
\end{tabular}

Although there are differences between measured and TMY2 average horizontal solar radiation levels on a monthly scale, the measured annual average horizontal solar radiation was only $1.8 \%$ less than the TMY2 data. The mild 2001-2002 winter is evident in the difference between TMY2 and measured average monthly temperatures during the winter months of 2001 and 2002. This is further demonstrated by the reduced measured HDD, as graphed in Figure 5-21. 


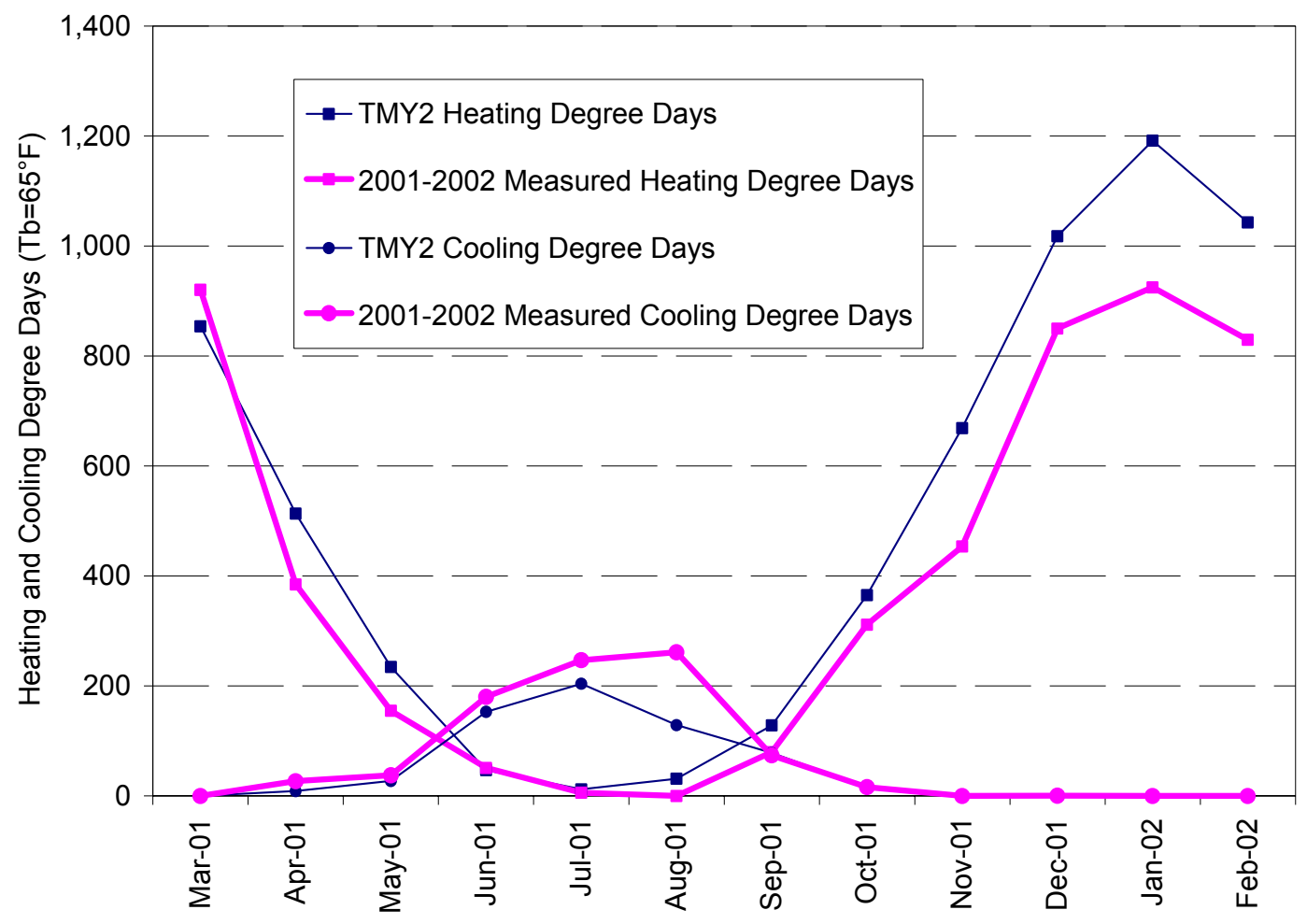

Figure 5-21 Measured and TMY2 HDD and CDD

There are 6,108 HDD for the TMY2 data at a base temperature of $65^{\circ} \mathrm{F}\left(18.3^{\circ} \mathrm{C}\right)$. From March 1, 2001 through February 28, 2002, there were $19 \%$ fewer measured HDD $\left(4,967^{\circ} \mathrm{F} \cdot\right.$ days $)$. During the summer of 2001, there were $27 \%$ more CDD than were seen in the TMY2 cooling season. For the third year of operation, there were 6,277 HDD, 3\% more than a TMY2 year. The HDD and CDD data were obtained from a DOE-2 weather statistics output.

\subsubsection{Development of Calibrated As-built Models}

NREL created an as-built model using DOE-2 to represent the operation and envelope of the Lewis Center from March 1, 2001 to February 28, 2002. NREL calibrated the As-built March 01-February 02 model using the lighting and equipment systems as described in Sections 4.2 and 4.5, respectively, including daylighting controls for appropriate spaces. The envelope was modeled as described in Table 4-1 and the representative geometry is shown in Figure 5-22. The thermal zones were modeled separately based on space use, location, and floor. The first floor thermal zones include two classrooms, the corridor, the bottom half of the stairwells, auditorium, wastewater treatment, the bottom half of the atrium, the mechanical room, and the bathroom/kitchen zone. Second floor thermal zones modeled include the conference room, resource room, a classroom, corridor, the offices, the top half of the atrium, the top half of the stairwells, and the auditorium mechanical room. 


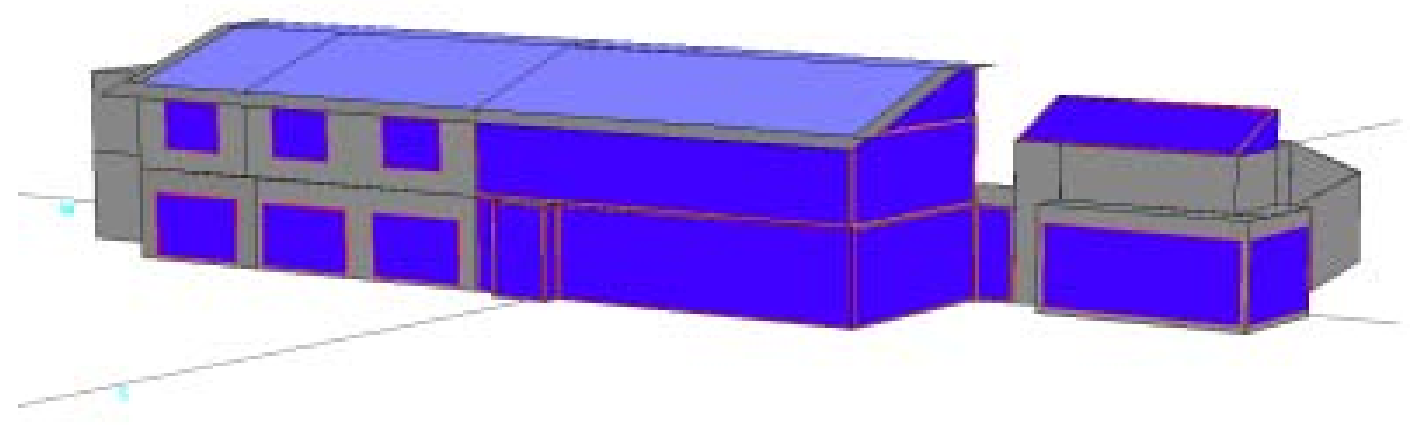

Figure 5-22 Representation of as-built DOE-2 model

The As-built March 01-February 02 model was calibrated using set points, which changed over the evaluation period. For occupied periods during March 2001 to June 2001, the heating set point for the classrooms, auditorium, atrium, and offices was $70^{\circ} \mathrm{F}\left(21^{\circ} \mathrm{C}\right)$, with a setback to $66^{\circ} \mathrm{F}\left(19^{\circ} \mathrm{C}\right)$ for unoccupied periods. The cooling set point for the classrooms, auditorium, and offices was modeled at $75^{\circ} \mathrm{F}\left(24^{\circ} \mathrm{C}\right)$, with a setup to $80^{\circ} \mathrm{F}\left(27^{\circ} \mathrm{C}\right)$ for unoccupied periods. The wastewater treatment heating set point was modeled at a constant $70^{\circ} \mathrm{F}\left(21^{\circ} \mathrm{C}\right)$, with no set back due to the specifications provided for the plants. The HVAC system was modeled as described in Section 4.4 using the manufacturer's rated performance data and some simplifying assumptions. Heat pump rated capacity, COP, and rated performance over the range of source temperatures were modeled based on expected performance as specified by the manufacturer (Carrier 2003). One limitation of the systems inputs to DOE-2 is that only one HVAC system can be applied to a space. Because of this limitation, one of the primary assumptions was in the modeling of the heat pump system. In the DOE-2 model, HP-5, which provides conditioned ventilation air to the classrooms and offices, was combined with the local console heat pumps and approximated as one large heat pump system with heat recovery for each space. This combined system supplies ventilation, heating, and cooling to the required zones. Part-load capacity ratios for ground source heat pumps were applied in this model to describe the diminished heat pump performance that results from low ground source loop temperatures. Other initial assumptions made in modeling the calibrated As-built March 01-February 02 building included occupancy, an infiltration rate of 0.2 air changes per hour during unoccupied nighttime hours, and an ERV effectiveness of $80 \%$.

After June 30, 2001, the occupants and facility operators made changes in the control of the Lewis Center. Preliminary analysis of the first 4 months of monitoring resulted in many building control changes. These changes are discussed further in the analysis sections. The occupants and the NREL evaluation team determined that the building was not being fully cooled during the warmer periods in June 2001. The console heat pump units were used only in the occupied offices and sparingly in the unoccupied classrooms to maintain the set-up cooling set point. Because the classrooms are typically unoccupied during this period of the year, they would normally not be air-conditioned. However, in order to assess cooling system energy performance if the facility were fully used in summer months, the building controls were changed to provide air-conditioning in the classrooms and auditorium as if they were occupied. This occurred during the months of July and August 2001. This control change was modeled for the remaining months of the cooling season to allow for a comparison to typical buildings that are fully occupied during the summer months. It is also anticipated that the building will be used more in the summertime for conferences and meetings. The evaluators do understand that set point changes alone do not completely reflect the actual cooling load that would be experienced if the building were occupied during the summer, as there was no occupancy induced cooling loads. The cooling schedule in the calibrated As-built March 01-February 02 model was modified to reflect this cooling set point. For the 
heating season, the scheduling of HP-5 was modified to supply conditioned outdoor air to the classrooms and offices only during occupied hours.

The evaluators also determined that the electric boiler (EB-1) was responsible for the majority of the heating energy consumption in March 2001. The boiler also governed the monthly demand on the building. To reduce the demand for this $112-\mathrm{kW}$ electric boiler, the heating set point in the wastewater treatment was reduced from a constant $70^{\circ} \mathrm{F}$ to $50^{\circ} \mathrm{F}\left(21^{\circ} \mathrm{C}\right.$ to $\left.10^{\circ} \mathrm{C}\right)$. The original set point was established for the health of the tropical plants. Further investigation determined that the tropical plants would thrive at temperatures above $50^{\circ} \mathrm{F}\left(10^{\circ} \mathrm{C}\right)$. To heat the atrium, the radiant floor heating system was shut off and HP-4 was controlled to heat the space. This heat pump is more efficient than the resistance heat of the radiant slab floor. EB-1 was still used to heat the wastewater treatment, bathrooms, kitchen, and corridors because there is no alternative system. This change allowed for a more efficient atrium heating system to operate during the winter of 2001-2002. To model this heating operational change, the atrium heating was removed from EB-1 and assigned to HP-4.

The occupancy schedules for the Lewis Center vary greatly by space and time of the year. The classrooms and auditorium in the model have an assumed expected occupancy based on scheduled classes during the semester from February through May and from September through December. The total number of occupants (occupant density as shown in Table 5-9) was based on available office, auditorium, and classroom seats and expected occupant utilization of these spaces. The classroom occupancy during weekday in-school months was modeled as $70 \%$ occupied from 10 a.m. to noon and from 1 to 4 p.m., and $30 \%$ occupied from 9 to 10 a.m., noon to 1 p.m., and 4 to 9 p.m. The classrooms were assumed empty during all other hours. The auditorium was assumed to be $40 \%$ occupied during weekdays and in-school months from 10 a.m. to 2 p.m. and unoccupied for all other hours. For weekends and out-of-school periods, the classrooms and auditorium were assumed unoccupied. The second-floor offices have a constant year-round occupancy pattern. They were assumed to be $70 \%$ occupied from 9 a.m. to 5 p.m. during the week and unoccupied for all other hours and on weekends. The occupancy schedule for the atrium and all other spaces depended on occasional functions, but was assumed unoccupied. These modeled occupancy schedules were not based on measured occupancy; rather they are based on room schedules and occupant feedback. A summary of the classroom schedules is included in Appendix B.

The As-built March 01-February 02 lighting schedule was modeled based on the hourly occupancy of each space. The as-built lighting scheduling attempted to simulate the actual occupancy controls as described in Section 2.2. The lighting schedule was not the same as the Base case, in which the lighting schedule assumed that the indoor lights would be on from the first occupied hour of the day until the last occupied hour of the day.

To verify that the as-built model and accompanying assumptions were adequate, the modeled energy performance from March 1, 2001, to February 28, 2002, was compared to the actual measured energy performance over this period. For a proper comparison, the measured local weather data from March 1, 2001, to February 28, 2002, was used as the weather file in the as-built simulation. Each of the primary measured end uses (HVAC, lighting, and equipment) was compared to the simulated end uses to allow for the model calibration. To calibrate the model, assumptions such as heating and cooling schedules, occupancy schedules, and unoccupied infiltration were slightly tuned until the energy performance of the calibrated As-built March 01-February 02 model described the measured energy performance. These calibrated schedules were also used in the comparison Base-case model. The rated ERV effectiveness, as discussed in Section 6.2.1, was used to model the ERV performance. The expected heat pump efficiencies were also used to calibrate the model, as discussed in Section 6.2.2. For the model to describe the actual building energy performance within expected simulation accuracy, the difference between modeled and measured monthly energy totals should be less than $12.0 \%$ (Energy Simulation Specialists, Inc. 1995). The evaluators also used daily load shape profile comparisons of the lighting, equipment, and HVAC to ensure appropriate as-built model representation. The results of the calibration 
of the As-built March 01-February 02 model, by end use, are shown in Figure 5-23. A comparison of the monthly measured and simulated totals is provided in Table 5-7.

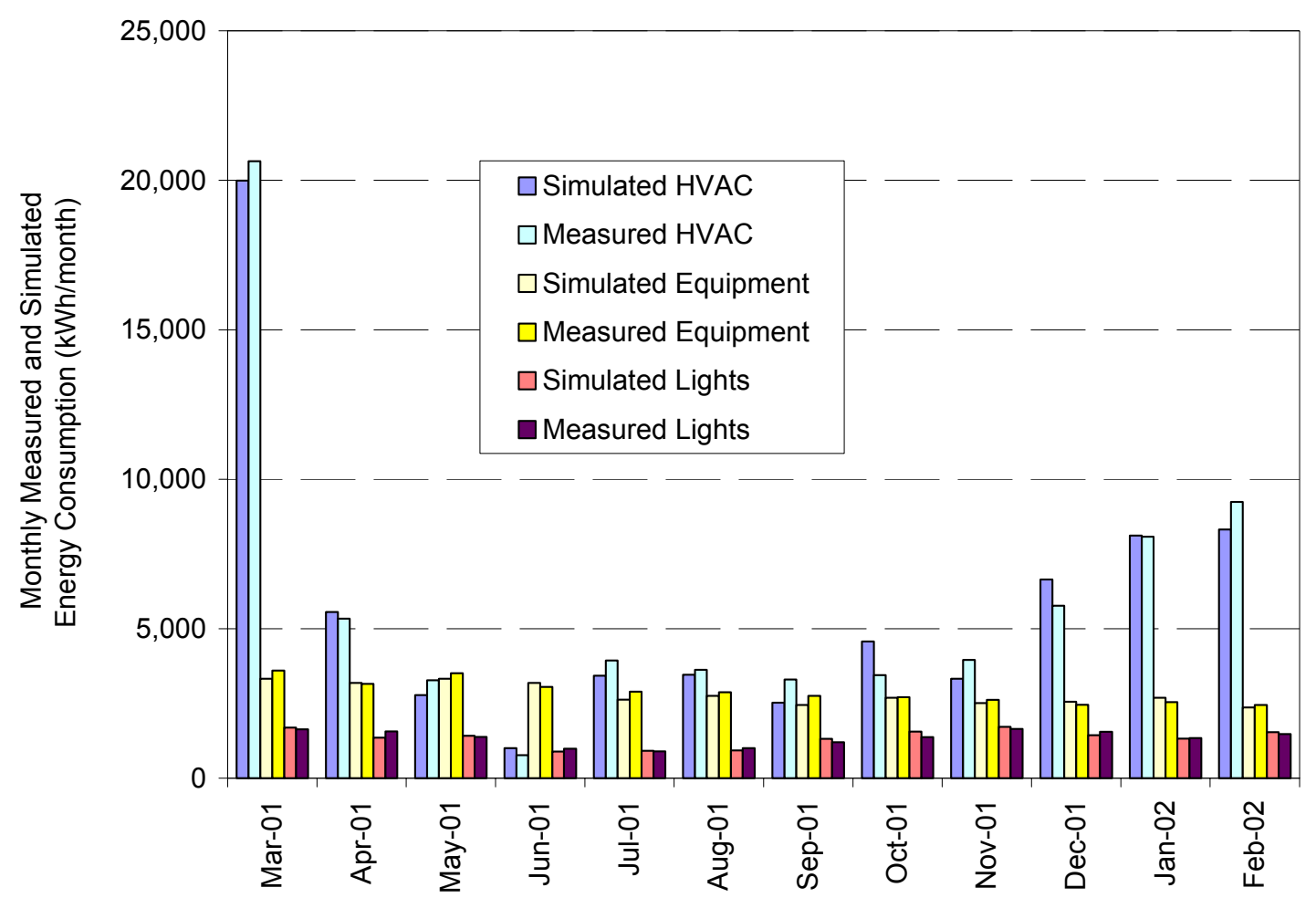

Figure 5-23 Results of the calibrated As-built March 01-February 02 model: measured weather simulated and measured HVAC, equipment, and lighting 
Table 5-7 Simulated Use and Measured Use Monthly Comparison

\begin{tabular}{|l|c|c|c|}
\hline & $\begin{array}{c}\text { Simulated } \\
\text { Total Use } \\
\mathbf{( k W h )}\end{array}$ & $\begin{array}{c}\text { Measured } \\
\text { Total Use } \\
\mathbf{( k W h )}\end{array}$ & $\begin{array}{c}\text { Percent } \\
\text { Difference }\end{array}$ \\
\hline March-01 & 25,019 & 25,878 & -3 \\
\hline April-01 & 10,121 & 10,060 & 1 \\
\hline May-01 & 7,534 & 8,174 & -8 \\
\hline June-01 & 5,285 & 4,780 & 10 \\
\hline July-01 & 6,977 & 7,740 & -11 \\
\hline August-01 & 7,152 & 7,509 & -5 \\
\hline September-01 & 6,291 & 7,270 & -16 \\
\hline October-01 & 8,824 & 7,530 & 15 \\
\hline November-01 & 7,562 & 8,232 & -9 \\
\hline December-01 & 10,644 & 9,782 & 8 \\
\hline January-02 & 12,137 & 11,969 & 1 \\
\hline February-02 & 12,236 & 13,175 & -8 \\
\hline Totals & 119,782 & 122,139 & -2 \\
\hline
\end{tabular}

To calculate the expected performance of the Lewis Center for the third year of operation, the evaluators created an as-built model (As-built March 02-February 03) that included the hydronic heat pump system. EB-1 was removed from the hydronic system and a ground source water-to-water heat pump was added. This system is described in Section 5.2.4. This model was then calibrated with the previously described procedures to represent the measured energy performance from March 1, 2002, to February 28, 2003. The calibrated occupancy, lighting, equipment, and ventilation schedules were similar to the schedules in the calibrated As-built March 01-February 02 model, as differences in annual building use patterns have been minimal.

\subsubsection{Development of Base-Case Model}

To establish a benchmark, the evaluators created an all-electric Base-case model of a conventional, ASHRAE Standard 90.1-2001 energy code-compliant building (ASHRAE 2001a). The Base-case model was developed as specified in Addendum E of ASHRAE 90.1-2001. Although the building was designed and built before 2001, the 2001 version of ASHRAE 90.1 was used because future renovations and upgrades are expected. The evaluators used this model to generate baseline energy performance data for a conventional building for comparison with data from the calibrated as-built models, using TMY2 weather data. The Base-case building is a solar-neutral, two-story building of equal size and space use. The footprint of the Base-case model is $82.5 \mathrm{ft}$ by $82.5 \mathrm{ft}(25.1 \mathrm{~m}$ by $25.1 \mathrm{~m})$, with a gross floor area of $13,600 \mathrm{ft}^{2}\left(1260 \mathrm{~m}^{2}\right)$. This model included the same amount of glass as the as-built building. The window-to-wall ratio is $43 \%$. In addition, the Base-case building, shown Figure 5-24, does not take advantage of daylighting to reduce the lighting load and has no window overhangs, as directed in ASHRAE 90.1, Addendum E. Table 5-8 summarizes the minimum allowable thermal characteristics of the envelope used in the Base-case model. See Table 4-1 for the as-built envelope thermal characteristics. 


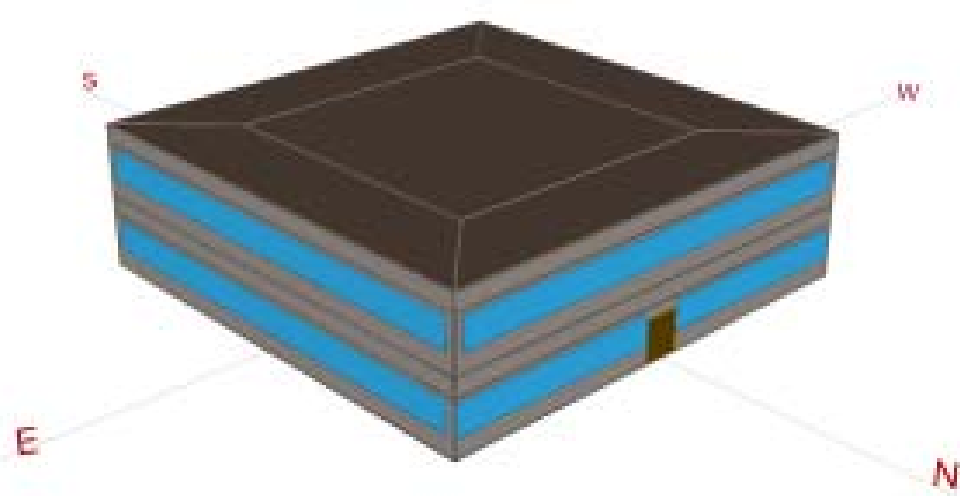

Figure 5-24 Representation of DOE-2 solar-neutral, Base-case model

Table 5-8 Base-case Envelope Minimum Allowable Thermal Characteristics

\begin{tabular}{|l|l|l|}
\hline Envelope Component & \multicolumn{1}{|c|}{ Assembly Minimum } \\
\hline $\begin{array}{l}\text { Roof with insulation } \\
\text { above decking }\end{array}$ & $\mathrm{R}_{\mathrm{eff}}-15.9 \mathrm{hr} \cdot \mathrm{ft}^{2} \cdot{ }^{\circ} \mathrm{F} / \mathrm{Btu}$ & $\mathrm{R}_{\mathrm{eff}}-2.8 \mathrm{~m}^{2} \cdot \mathrm{K} / \mathrm{W}$ \\
\hline $\begin{array}{l}\text { Exterior mass walls } \\
\text { above grade }\end{array}$ & $\mathrm{R}_{\mathrm{eff}}-8.1 \mathrm{hr} \cdot \mathrm{ft}^{2} \cdot{ }^{\circ} \mathrm{F} / \mathrm{Btu}$ & $\mathrm{R}_{\mathrm{eff}}-1.4 \mathrm{~m}^{2} \cdot \mathrm{K} / \mathrm{W}$ \\
\hline Slab-on-grade floor & $\begin{array}{l}\mathrm{F} \text {-factor }=0.84 \text { with } \mathrm{R}-10 \mathrm{hr} \cdot \mathrm{ft}^{2} \cdot{ }^{\circ} \mathrm{F} / \mathrm{Btu} \\
\text { vertical perimeter insulation }\end{array}$ & $\begin{array}{l}\mathrm{F} \text {-factor }=0.84 \text { with } \mathrm{R}-1.8 \mathrm{~m}^{2} \cdot \mathrm{K} / \mathrm{W} \\
\text { vertical perimeter insulation }\end{array}$ \\
\hline $\begin{array}{l}\text { Operable double pane } \\
\text { windows with thermally } \\
\text { broken frames }\end{array}$ & $\begin{array}{l}\mathrm{R}_{\mathrm{eff}}-2.1 \mathrm{hr} \cdot \mathrm{ft}^{2} \cdot{ }^{\circ} \mathrm{F} / \mathrm{Btu} \text { with solar heat } \\
\text { gain coefficient }=0.49\end{array}$ & $\begin{array}{l}\mathrm{R}_{\text {eff }}-0.4 \mathrm{~m}^{2} \cdot \mathrm{K} / \mathrm{W} \text { with solar heat gain } \\
\text { coefficient }=0.49\end{array}$ \\
\hline
\end{tabular}

The Base-case model included packaged single-zone, air-cooled heat pump heating and cooling systems that included a supplemental electric resistance heater. The Base-case heat pump systems were modeled with cooling seasonal energy efficiency ratio (SEER) of 9.7 and a heating COP of 2.0. The heating and cooling equipment types were based on typical electrical HVAC equipment and the efficiencies were specified by ASHRAE 90.1-2001. A dry-bulb economizer was also modeled. The energy code specifies maximum lighting power densities, and these and other space conditions are included in the Base-case model and summarized in Table 5-9. The equipment power density $\left(\mathrm{W} / \mathrm{ft}^{2}\right)$ was modeled based on the installed equipment in each space, including the process loads of the wastewater treatment.

Table 5-9 Base-case Space Conditions

\begin{tabular}{|l|c|c|c|c|}
\hline Space Type & $\begin{array}{c}\text { Area } \\
\mathrm{ft}^{2}\left(\mathrm{~m}^{2}\right)\end{array}$ & $\begin{array}{c}\text { Occupancy } \\
\text { Density } \\
\text { people/1000 } \mathrm{ft}^{2} \\
\left.\text { (people/1000 } \mathrm{m}^{2}\right)\end{array}$ & $\begin{array}{c}\text { Ventilation } \\
\text { cfm/person } \\
(\mathrm{L} / \mathrm{s} / \text { person) }\end{array}$ & $\begin{array}{c}\mathrm{LPD} \\
\mathrm{W} / \mathrm{ft}^{2} \\
\left(\mathrm{~W} / \mathrm{m}^{2}\right)\end{array}$ \\
\hline \hline Offices & 1,590 & 7.0 & 20.0 & 1.5 \\
Classrooms/auditorium & $(148)$ & $(0.7)$ & $(9.4)$ & $(16.1)$ \\
\hline Corridors/transitions/other & $(3910$ & 30.0 & 15.0 & 1.6 \\
& 6,000 & $(2.8)$ & $(7.1)$ & $(17.2)$ \\
\hline Atrium & $(557)$ & 0.0 & 0.0 & 0.7 \\
& 1,800 & $(0.0)$ & $(0.0)$ & $(7.5)$ \\
\hline
\end{tabular}


For the Base-case model, the occupancy schedules were based on the calibrated occupancy schedules from the calibrated As-built March 01-February 02 and As-built March 02-February 03 models. The equipment and lighting schedules were based on these occupancy schedules. For each space, the lights were assumed to be on from the first occupied hour of the day until the last occupied hour of the day. The lights in the atrium and transition spaces are scheduled on whenever any space in the building is occupied. In typically unoccupied zones, such as mechanical rooms, the lights are scheduled off in the model. The Base-case lighting schedule assumes the occupants would not manually turn off the lights during these occupied periods, as is typical in conventional educational buildings. This assumption also attempts to simulate a Base-case lighting model that does not include occupancy or daylighting controls. The idea is to capture the typical lighting control in a conventional academic building, where atrium and corridor lights are typically on whenever the building is occupied. Also included in the lighting schedule were the $2.0-\mathrm{kW}$ sidewalk and parking lot lights and $0.5 \mathrm{~kW}$ of emergency and entrance lighting scheduled to operate at night.

The Base-case heating and cooling set points were modeled using the calibrated temperature schedules from the As-built March 01-February 02 and the As-built March 02-February 03 models. The Base-case model was then simulated using TMY2 weather data from Cleveland, Ohio. The Base-case model that included the second year calibrated schedules was used to compare to the As-built March 01-February 02 model with TMY2 data. The Base-case model that included the third year of calibrated schedules was used to compare to the As-built March 02-February 03 model with TMY2 data. Table 5-10 summarizes the building models used in this analysis.

Table 5-10 Building Model Summary

\begin{tabular}{|l|l|l|}
\hline \multicolumn{1}{|c|}{ Model Name } & \multicolumn{1}{|c|}{ Model Version } & \multicolumn{1}{c|}{ Model Use } \\
\hline \hline \multirow{2}{*}{$\begin{array}{l}\text { As-Built March 01- } \\
\text { February 02 }\end{array}$} & $\begin{array}{l}\text { March 01 - February 02 } \\
\text { measured weather }\end{array}$ & $\begin{array}{l}\text { Used to calibrate the second year as-built } \\
\text { model against measured data }\end{array}$ \\
\cline { 2 - 3 } & Cleveland TMY2 & $\begin{array}{l}\text { Used to predict the second year energy } \\
\text { use for a typical weather year }\end{array}$ \\
\hline \multirow{3}{*}{$\begin{array}{l}\text { As-Built March 02- } \\
\text { February 03 }\end{array}$} & $\begin{array}{l}\text { March 02 - February 03 } \\
\text { measured weather }\end{array}$ & $\begin{array}{l}\text { Used to calibrate the third year as-built } \\
\text { model against measured data }\end{array}$ \\
\cline { 2 - 3 } Base Case & Cleveland TMY2 & $\begin{array}{l}\text { Used to predict the third year energy use } \\
\text { for a typical weather year }\end{array}$ \\
\hline \hline \multirow{2}{*}{ Optimized } & $\begin{array}{l}\text { As-Built March 01-February 02 } \\
\text { Schedules with TMY2 }\end{array}$ & $\begin{array}{l}\text { Used to calculate second year energy } \\
\text { savings for a typical weather year }\end{array}$ \\
\cline { 2 - 3 } & $\begin{array}{l}\text { As-Built March 02-February 03 } \\
\text { Schedules with TMY2 }\end{array}$ & $\begin{array}{l}\text { Used to calculate third year energy savings } \\
\text { for a typical weather year and energy } \\
\text { savings of the Optimized model }\end{array}$ \\
\hline \hline & $\begin{array}{l}\text { As-Built March 02-February 03 } 03 \\
\text { Schedules with TMY2 }\end{array}$ & $\begin{array}{l}\text { Used to predict the optimized energy } \\
\text { performance for a typical weather year }\end{array}$ \\
\hline
\end{tabular}

\subsection{Whole-building Energy Performance Results, 2001-2002}

The primary energy performance metrics for the Lewis Center were site energy consumption, production, and savings. The primary metric was site energy performance as it was the basis for the original energy goal of the project. To be consistent with other case studies, source energy consumption and energy costs are also reported. The results of the evaluation of the Lewis Center based on these metrics, using the Base-case model and as-built building models, are included in the following sections.

Different metrics can be used to tell different stories about the building. Source energy implies the total environmental impact of the site from an energy perspective, but does not relate to emissions. The PV system was integral to the building design and offsets energy on the site. The source energy numbers, 
therefore, include PV. Site energy has broader uses. The site energy can be used to compare performance of buildings, with or without PV. As a result, both numbers are presented. Cost is useful as most building owners make decisions based on cost.

\subsubsection{Site Energy Savings}

The first DOE-2 model considered was the ASHRAE 90.1-2001 all-electric Base-case building as developed in Section 5.3.5. Based on TMY2 weather data for Cleveland, the simulated annual Base-case energy site consumption was $214,807 \mathrm{kWh}(773,305 \mathrm{MJ})$. The annual Base-case site energy consumption intensity was $53.9 \mathrm{kBtu} / \mathrm{ft}^{2} \cdot \mathrm{yr}\left(612 \mathrm{MJ} / \mathrm{m}^{2} \cdot \mathrm{yr}\right)$ based on the building size of $13,600 \mathrm{ft}^{2}$ $\left(1,260 \mathrm{~m}^{2}\right)$.

To compare the performance of the as-built building with the base-case building, both models were run using TMY2 data. Recall that both models use actual schedules and plug loads based on measured data from March 2001 to February 2002.

The simulated As-built March01-February02 energy consumption was 149,952 kWh (539,827 MJ) for site energy, with a site consumption energy intensity of $37.6 \mathrm{kBtu} / \mathrm{ft}^{2} \cdot \mathrm{yr}\left(427 \mathrm{MJ} / \mathrm{m}^{2} \cdot \mathrm{yr}\right)$. This corresponds to a $30 \%$ savings as compared to the Base case. The PV system production was simulated to be $64,500 \mathrm{kWh}(232 \mathrm{GJ})$, or $16.2 \mathrm{kBtu} / \mathrm{ft}^{2} \cdot \mathrm{yr}\left(184 \mathrm{MJ} / \mathrm{m}^{2} \cdot \mathrm{yr}\right)$. The typical PV production is the sum of PV production used on site and exported to the grid over the year. The simulation of PV production is discussed in Section 6.3. When the simulated PV production is considered, the 2001-2002 net annual site consumption would have been $85,452 \mathrm{kWh}(307,630 \mathrm{MJ})$. This amount results in a net site consumption of $21.4 \mathrm{kBtu} / \mathrm{ft}^{2} \cdot \mathrm{yr}\left(243 \mathrm{MJ} / \mathrm{m}^{2} \cdot \mathrm{yr}\right)$ and $60 \%$ savings as compared to the TMY2 Base case. Refer to Table 5-11 for a summary of these comparisons. The savings distribution is depicted in Figure 5-25.

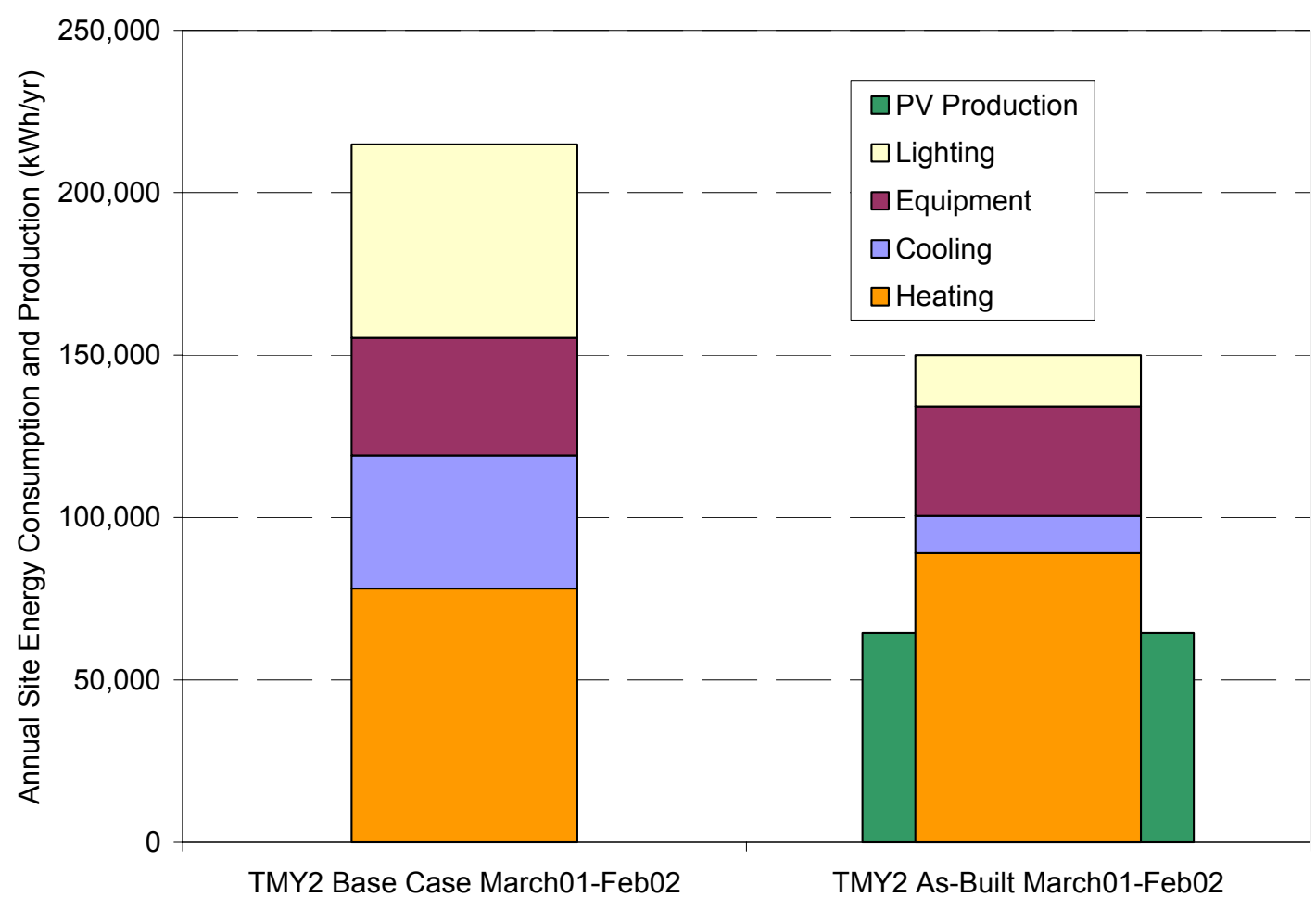

Figure 5-25 Annual site energy consumption of ASHRAE 90.1-2001 TMY2 Base case versus TMY2 simulated as-built model. 
The simulated as-built lighting consumption was $72 \%$ less than the Base case, because of a reduced lighting power density, daylighting, and occupancy/daylighting controls. Further discussion of the lighting savings is included in the daylighting section (Section 6.4). The simulated as-built HVAC consumption was $16 \%$ less than the Base case. The heating and cooling categories include ventilation fan consumption while the building was in heating or cooling mode. The TMY2 As-built March 01-

February 02 model predicts more heating than the TMY2 Base case, primarily due to the electric boiler and hydronic system. Cooling energy savings of $72 \%$ were largely due to reduced internal lighting gains and a more efficient ground source heat pump system. There were no equipment savings, as there is no equipment power density difference between the Base case and the as-built building.

Table 5-11 Site Energy Consumption and Savings for the Base case and As-built Model

\begin{tabular}{|l|c|c|c|c|}
\hline Model & $\begin{array}{c}\text { Site } \\
\text { Consumption } \\
\text { Energy Intensity } \\
\text { without } \boldsymbol{P V} \\
\mathrm{kBtu} / \mathrm{ft}^{2} / \mathrm{yr} \\
\left(\mathrm{MJ} / \mathrm{m}^{2} / \mathrm{yr}\right)\end{array}$ & $\begin{array}{c}\text { Site } \\
\text { Consumption } \\
\text { Percent Savings } \\
\text { as Compared to } \\
\text { Base case }\end{array}$ & $\begin{array}{c}\text { Net Site } \\
\text { Consumption } \\
\text { Energy Intensity } \\
\text { with } P V \\
\mathrm{kBtu} / \mathrm{ft}^{2} / \mathrm{yr} \\
\left(\mathrm{MJ} / \mathrm{m}^{2} / \mathrm{yr}\right)\end{array}$ & $\begin{array}{c}\text { Net Site } \\
\text { Consumption } \\
\text { Percent Savings } \\
\text { as Compared to } \\
\text { Base case }\end{array}$ \\
\hline $\begin{array}{l}\text { TMY2 Base Case } \\
\text { March 01- } \\
\text { February 02 }\end{array}$ & 53.9 & N.A. & $\begin{array}{c}53.9 \\
(612)\end{array}$ & N.A. \\
\hline $\begin{array}{l}\text { TMY2 As-built } \\
\text { March 01- } \\
\text { February 02 }\end{array}$ & $(612)$ & $30 \%$ & $\begin{array}{c}21.4 \\
(243)\end{array}$ & $60 \%$ \\
\hline
\end{tabular}

\subsubsection{Source Energy Savings}

As discussed previously, source or primary energy is the sum of the energy directly consumed at the site and the energy consumed by producing and delivering energy products. Documenting primary energy consumption is useful when emissions from energy sources are a concern.

The on-site electricity generation offsets the consumption of site electricity and the corresponding conversion and transmission losses. Therefore, the net site energy consumption (total consumption minus $\mathrm{PV}$ production) was used to calculate the total source energy required to meet the Lewis Center's annual site electricity load.

Some cautions related to this analysis. Source energy considers the impact of the total site traced back to source energy. As the building was designed with a vision of net-zero site energy, design decisions were made to use an all-electric building with electricity offset with PV generation. Source energy savings are highly dependent on this decision and should include the PV production, as it is integral to the building's goals. Note it is possible to reach various conclusions based on this data depending on whether PV is or is not included. One consequence of this type of source energy analysis is that large PV systems could be installed on typical buildings in an effort to make a typical building a low-energy building (with respect to source energy use). To capture the performance of the building (without PV), site energy use and energy costs should also be considered. Next, if source energy were the ultimate goal rather than site energy, it would be more advantageous to use natural gas to heat the building and export additional electricity. As most of the electricity is generated with coal, this involves fuel switching and ignores the value of the fuel sources. Finally, the source numbers ignore the variations in conversion rates based on time of day. The local utility uses diesel fuel to generate peak load power that costs considerably more than coal generation. The utility benefits from buildings, such as this, that export energy during the day. This analysis uses average utility information to calculate source energy use. Time dependent source energy conversion rates are difficult to obtain and are dependent on the dispatch management of the utility. 
The all-electric TMY2 Base-case building (described in Section 5.3.5) consumed 691,678 kWh (2,490 GJ) of source energy when simulated with TMY2 weather data. The annual Base-case source energy consumption intensity was $173.5 \mathrm{kBtu} / \mathrm{ft}^{2} \cdot \mathrm{yr}\left(1,970 \mathrm{MJ} / \mathrm{m}^{2} \cdot \mathrm{yr}\right)$. The Base-case source energy was calculated based on $31 \%$ electricity conversion and delivery efficiency from source to site. The electrical source-to-site efficiency was based on the conversion and distribution efficiency averaged over all sources of electricity generation in the nation, as reported by EIA (2000).

The simulated net site energy consumption for a typical weather year was $85,452 \mathrm{kWh}(307,670 \mathrm{MJ})$, or $21.4 \mathrm{kBtu} / \mathrm{ft}^{2} \cdot \mathrm{yr}\left(243 \mathrm{MJ} / \mathrm{m}^{2} \cdot \mathrm{yr}\right)$. This net use was based on the simulated consumption for a TMY2 weather year with the As-built March 01-February 02 model and the expected PV production. The expected PV production was calculated as described in Section 6.3.2.5. At 31\% source-to-site electricity conversion efficiency, NREL calculated a typical source energy consumption of $68.9 \mathrm{kBtu} / \mathrm{ft}^{2} \cdot \mathrm{yr}(782$ $\mathrm{MJ} / \mathrm{m}^{2} \cdot \mathrm{yr}$ ). The second year Lewis Center source energy intensity was similar to other high-performance academic buildings, as discussed in Section 2.1. Additionally, the Lewis Center realized a simulated source energy consumption savings of $60 \%$ compared to the TMY 2 Base-case source energy consumption, as shown in Figure 5-26. The source energy savings would be significantly less for this building if the PV system did not meet some of the building load.

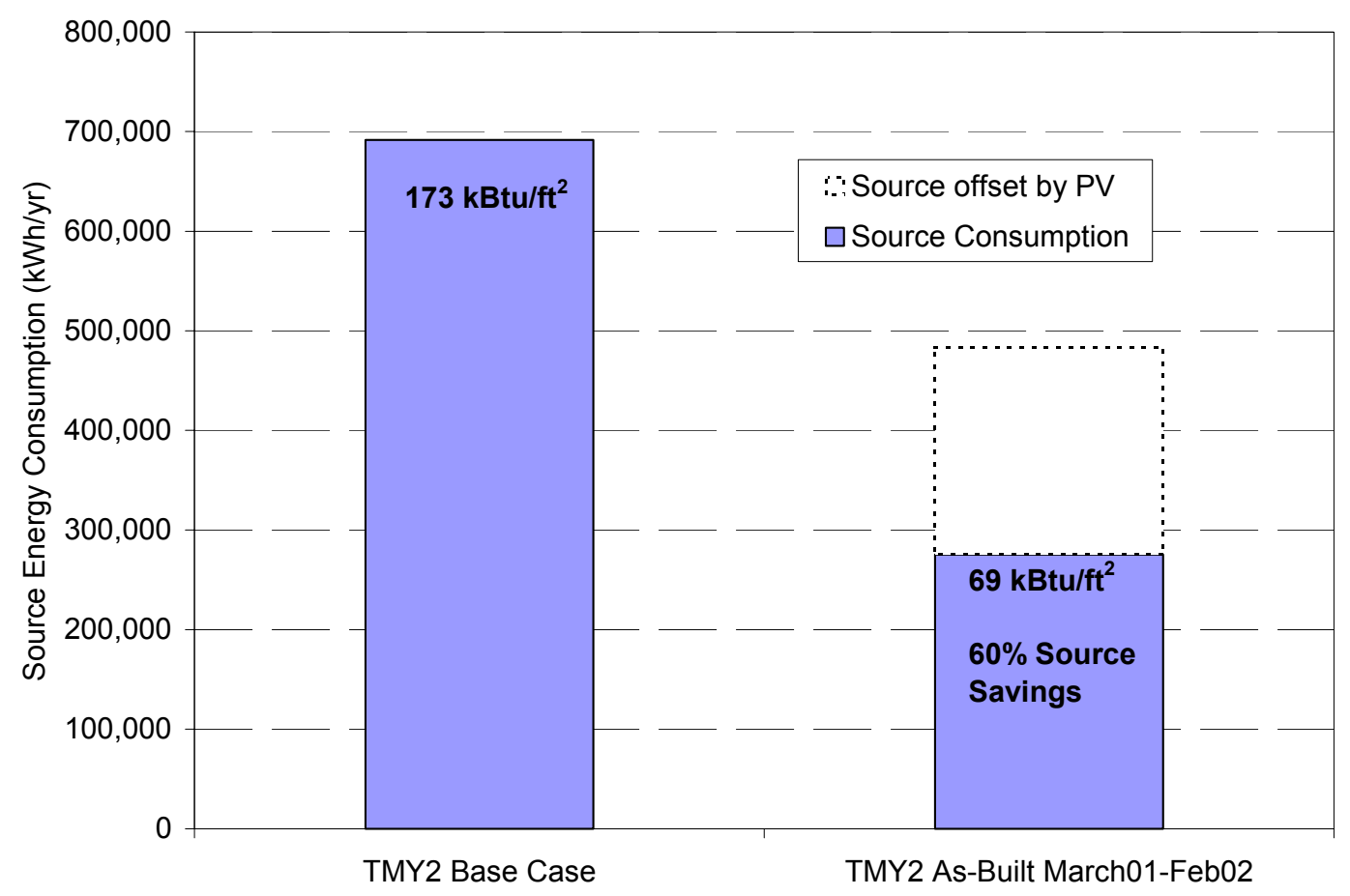

Figure 5-26 Annual source energy consumption of ASHRAE 90.1-2001 Base case versus TMY2 simulated as-built model with typical PV production

NREL also calculated emission reductions based on source energy consumption for typical weather years for the as-built Lewis Center and the conventional Base case. Electricity emissions were calculated based on the data given in Table 5-12 and a 10\% transmission and distribution loss from the generation location to the site. Table 5-12 summarizes emissions for electricity generated in Ohio (DOE 2003). 
Table 5-12 Ohio Electricity Generation Emissions

\begin{tabular}{|l|c|}
\hline \multicolumn{1}{|c|}{ Emissions } & $\begin{array}{c}\text { Emissions Amount per Unit } \\
\text { of Electricity Generated } \\
\text { lbs/MWh }(\mathrm{kg} / \mathrm{MWh})\end{array}$ \\
\hline $\mathrm{CO}_{2}$ (carbon dioxide) & $2131.1(966.7)$ \\
\hline $\mathrm{SO}_{2}$ (sulfur dioxide) & $22.9(10.4)$ \\
\hline $\mathrm{NO}_{\mathrm{X}}$ (oxides of nitrogen) & $7.5(3.4)$ \\
\hline $\mathrm{CO}$ (carbon monoxide) & $0.3(0.1)$ \\
\hline $\mathrm{HC}$ (hydro carbon) & $0.07(0.03)$ \\
\hline $\mathrm{PM}$ (particulate matter) & $0.1(0.05)$ \\
\hline $\mathrm{C}_{\text {eq }}$ (carbon equivalent) & $1203.0(545.7)$ \\
\hline
\end{tabular}

NREL estimates annual emissions saved to be $303,233 \mathrm{lbs}(137,544 \mathrm{~kg})$ of $\mathrm{CO}_{2}, 3,263 \mathrm{lbs}(1,480 \mathrm{~kg})$ of $\mathrm{SO}_{2}, 1,063 \mathrm{lbs}(482 \mathrm{~kg})$ of $\mathrm{NO}_{\mathrm{X}}, 44 \mathrm{lbs}(20 \mathrm{~kg})$ of CO, $10 \mathrm{lbs}(4.4 \mathrm{~kg})$ of HC, $15 \mathrm{lbs}(6.8 \mathrm{~kg})$ of PM, and $171,175 \mathrm{lbs}(77,644 \mathrm{~kg})$ of $\mathrm{C}_{\mathrm{eq}}$ when compared with emissions from the Base case. These results are summarized in Table 5-13.

Table 5-13 Emissions Reduction Summary

\begin{tabular}{|l|c|r|r|}
\hline & $\begin{array}{c}\text { TMY2 Base case } \\
\text { Emissions } \\
\text { lbs }(\mathrm{kg})\end{array}$ & $\begin{array}{c}\text { TMY2 As-built } \\
\text { March 01-February 02 } \\
\text { Emissions lbs }(\mathrm{kg})\end{array}$ & $\begin{array}{c}\text { Emissions } \\
\text { Reductions } \\
\text { lbs }(\mathrm{kg})\end{array}$ \\
\hline \hline $\mathrm{CO}_{2}$ & 503,549 & 200,316 & 303,233 \\
$(228,406)$ & $(90,862)$ & $(137,544)$ \\
\hline $\mathrm{SO}_{2}$ & 5,418 & 2,155 & 3,263 \\
& $(2,458)$ & $(977)$ & $(1,480)$ \\
$\mathrm{NO}_{\mathrm{x}}$ & 1,766 & 702 & 1,063 \\
$\mathrm{CO}$ & $(801)$ & $(318)$ & $(482)$ \\
\hline $\mathrm{HC}$ & 73 & 29 & $(20)$ \\
\hline $\mathrm{PM}$ & $(33)$ & $(13)$ & $(4)$ \\
\hline $\mathrm{C}$ & 16 & 6 & 15 \\
& $(7)$ & $(3)$ & $(7)$ \\
\hline
\end{tabular}

\subsubsection{Energy Cost Savings}

The third relevant energy performance index used by the evaluation team was the cost of energy. To calculate the energy costs for the Base case, the as-built model utility rate structure was applied to the Base-case model. The Base case was then simulated using the March 2001 through February 2002 measured site weather data. This allowed for a comparison of the Base-case energy costs and the actual utility bills. It is not possible to model the as-built energy costs with DOE-2, as sub-hourly demand and integrated PV production calculations are required to determine actual monthly peak demand charges.

The March 2001 through February 2002 electricity cost intensity was $\$ 1.17 / \mathrm{ft}^{2}\left(\$ 12.59 / \mathrm{m}^{2}\right)$. The Basecase electricity cost, simulated with measured site weather data, was $\$ 1.20 / \mathrm{ft}^{2}\left(\$ 12.92 / \mathrm{m}^{2}\right)$. Minimal 
energy cost savings was realized from March 2001 through February 2002. The previously discussed high demand charges and uncredited power exports (Section 5.2.3.2) were the primary reason for minimal energy cost savings. If the Lewis Center had received credit for the $28,849 \mathrm{kWh}(103,856 \mathrm{MJ})$ of PV exports at the rate of $\$ 0.023 / \mathrm{kWh}$ and a distribution charge of $\$ 0.026 / \mathrm{kWh}$, the energy cost intensity would have been reduced by $9 \%$, at $\$ 1.07 / \mathrm{ft}^{2}\left(\$ 11.52 / \mathrm{m}^{2}\right)$. The monthly comparison of electricity charges between the Base case and second year utility bills is shown in Figure 5-27.

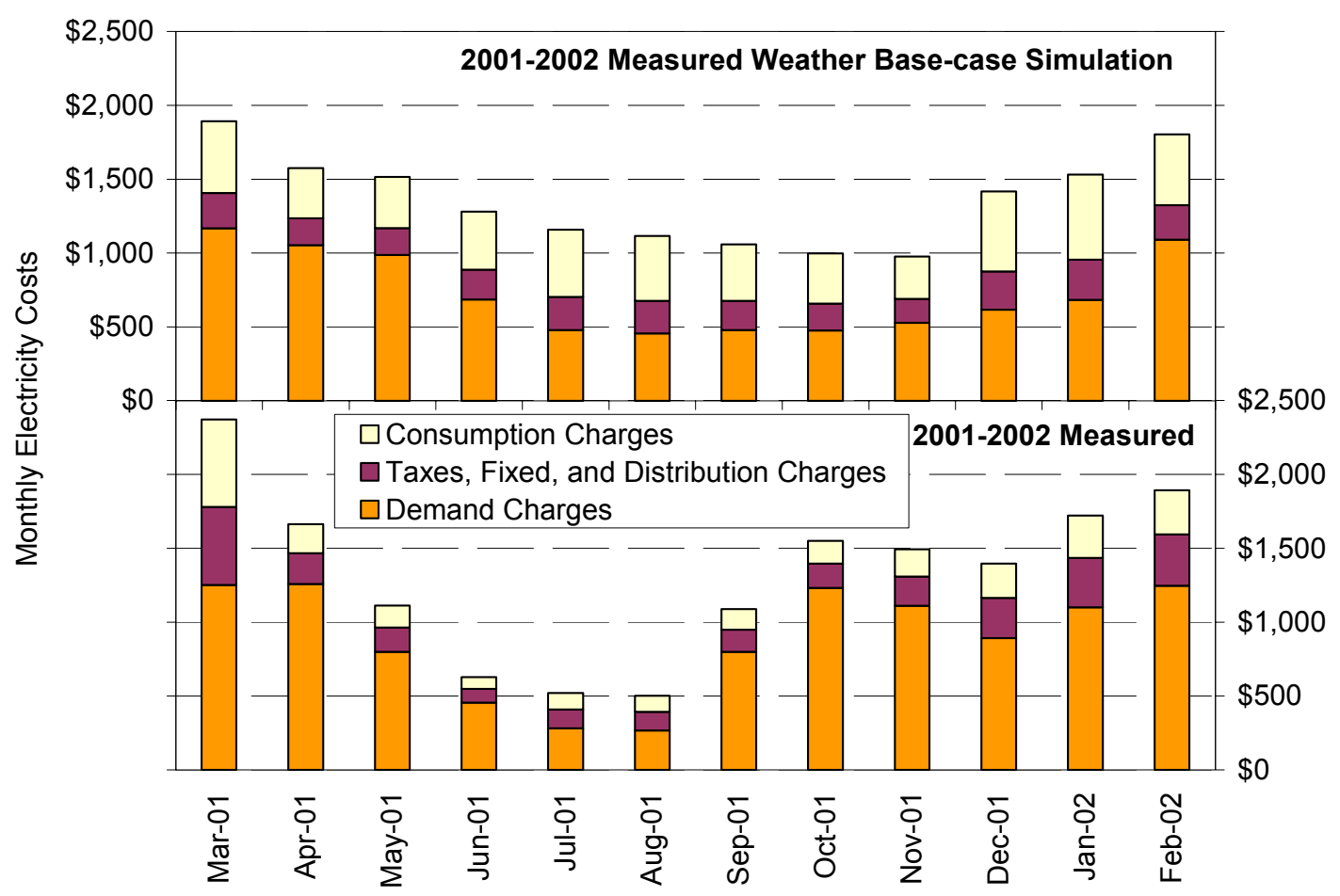

Figure 5-27 Monthly electricity charges, Base case and measured 2001-2002

\subsection{Whole-building Energy Performance Results, 2002-2003}

Although a detailed building simulation evaluation was not completed for the third year of Lewis Center operation, site energy savings, energy cost savings, and source energy savings have been tabulated. The energy performance for the third year of operation (March 2002 through February 2003) was evaluated. The third year of performance includes the hydronic system upgrade described in Section 5.2.4. The expected site energy consumption for a typical weather year was simulated based on a calibrated as-built simulation that used site weather data for the calibration process. Appendix C provides a detailed, monthly summary of end use consumption from March 2002 through February 2003.

For a typical weather year with the hydronic heat pump upgrade, the calibrated As-built March 02February 03 model predicts the Lewis Center would consume $109,560 \mathrm{kWh} / \mathrm{yr}$, or $27.5 \mathrm{kBtu} / \mathrm{ft}^{2} \cdot \mathrm{yr}$, and site energy savings of $48 \%$ compared to the Base case, as shown in Figure 5-28. The Base case used for the third year comparison was simulated based on calibrated third year occupancy, heating, and cooling schedules. The third year Base-case model, with TMY2 weather, simulated an annual energy use of $212,604 \mathrm{kWh}(765.4 \mathrm{GJ})$, at a site energy use intensity of $53.3 \mathrm{kBtu} / \mathrm{ft}^{2} \cdot \mathrm{yr}\left(605 \mathrm{MJ} / \mathrm{m}^{2} \cdot \mathrm{yr}\right)$. Annually, the Lewis Center saved 103,044 kWh (371 GJ) as compared to a conventional, code-compliant building. Of these annual site energy savings, the lighting system provided the greatest savings. For the third year, the lighting design combined with daylighting saved 44,033 kWh (159 GJ). A detailed breakdown of the 
lighting savings is included in Section 6.4. A savings of 26,629 $\mathrm{kWh}(95.9 \mathrm{GJ})$ resulted from the cooling system. The cooling system savings are primarily due to the expected increased COP of the ground source heat pumps, combined with reduced internal heating gains from the lights, and a better thermal envelope. The more efficient ground source heat pumps, combined with a better thermal envelope, resulted in $24,405 \mathrm{kWh}(87.9 \mathrm{GJ})$ of heating savings.

The actual measured annual consumption from March 2002 through February 2003 was 118,973 kWh $(428,302 \mathrm{MJ})$, or $29.8 \mathrm{kBtu} / \mathrm{ft}^{2} \cdot \mathrm{yr}\left(338 \mathrm{MJ} / \mathrm{m}^{2} \cdot \mathrm{yr}\right)$. The measured consumption was slightly higher than a typical year due to a colder than typical winter.

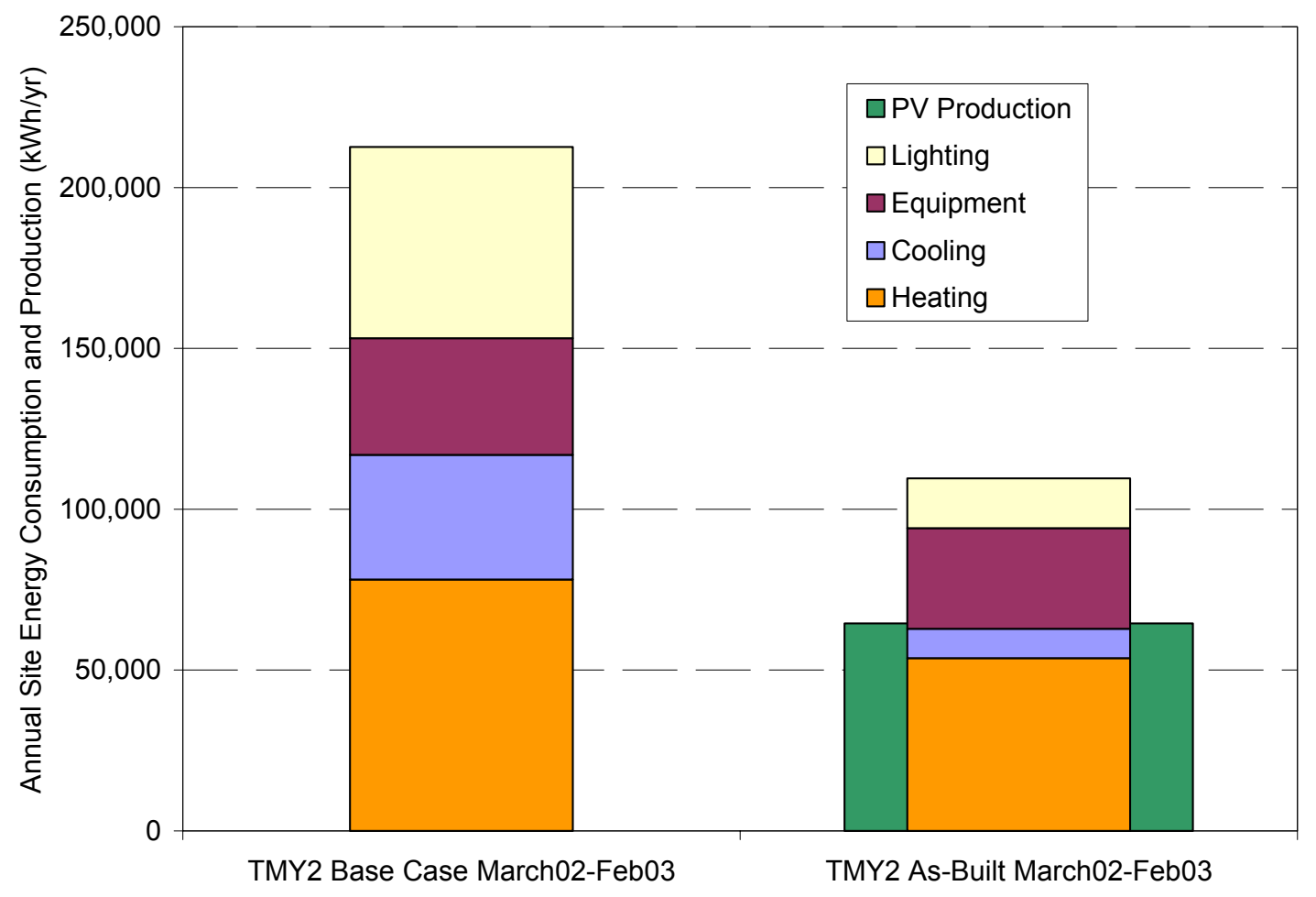

Figure 5-28 Annual Site Energy Consumption and production, TMY2 Base case and TMY2 As-built March 02-February 03

For a typical year, based on the third year of energy performance, the PV system would have met 59\% of the site-building load. Including the PV, the net site use resulted in a source energy consumption intensity of $36.5 \mathrm{kBtu} / \mathrm{ft}^{2} \cdot \mathrm{yr}\left(415 \mathrm{MJ} / \mathrm{m}^{2} \cdot \mathrm{yr}\right)$, at a source savings of $79 \%$.

Overall, the site and source savings have increased from the second to third year. The increased savings are primarily due to the heat pump upgrade. NREL estimates a heating end use savings of $35,277 \mathrm{kWh}$ (127 GJ), with heating use from the second to third year reduced by $40 \%$. As shown in Table 5-14, site savings have increased from $30 \%$ to $48 \%$, and net site savings increased from $60 \%$ to $79 \%$. 
Table 5-14 Site Energy Performance for Base case, Second, and Third Year As-built Models

\begin{tabular}{|c|c|c|c|c|}
\hline Model & $\begin{array}{c}\text { Site } \\
\text { Consumption } \\
\text { Energy Intensity } \\
\text { (without PV) } \\
\text { kBtu/ft }\left(\mathrm{MJ} / \mathrm{m}^{2}\right)\end{array}$ & $\begin{array}{c}\text { Site } \\
\text { Consumption } \\
\text { Percent Savings } \\
\text { as Compared to } \\
\text { Base case }\end{array}$ & $\begin{array}{c}\text { Net Site } \\
\text { Consumption } \\
\text { Energy Intensity } \\
\text { (with PV) } \\
\text { kBtu/ft }\left(M J / m^{2}\right)\end{array}$ & $\begin{array}{c}\text { Net Site } \\
\text { Consumption } \\
\text { Percent Savings } \\
\text { as Compared to } \\
\text { Base case }\end{array}$ \\
\hline \multicolumn{5}{|c|}{ Second Year (March 2001-February 2002) } \\
\hline TMY2 Base case & $\begin{array}{l}53.9 \\
(612)\end{array}$ & N.A. & $\begin{array}{r}53.9 \\
(612) \\
\end{array}$ & N.A. \\
\hline $\begin{array}{l}\text { TMY2 As-built } \\
\text { March 01- } \\
\text { February } 02 \\
\end{array}$ & $\begin{array}{l}37.6 \\
(427)\end{array}$ & $30 \%$ & $\begin{array}{l}21.4 \\
(243)\end{array}$ & $60 \%$ \\
\hline \multicolumn{5}{|c|}{ Third Year (March 2002-February 2003) } \\
\hline TMY2 Base case & $\begin{array}{l}53.3 \\
(605)\end{array}$ & N.A. & $\begin{array}{c}53.3 \\
(605)\end{array}$ & N.A. \\
\hline $\begin{array}{l}\text { TMY2 As-built } \\
\text { March 02- } \\
\text { February } 03\end{array}$ & $\begin{array}{l}27.5 \\
(312)\end{array}$ & $48 \%$ & $\begin{array}{l}11.3 \\
(128)\end{array}$ & $79 \%$ \\
\hline
\end{tabular}

The upgrade increased the energy cost savings as well. For the second year of operation, there was no energy cost savings due primarily to high demand charges. By replacing the hydronic electric boiler and adding a net-metering agreement, the annual energy costs have been reduced from $\$ 1.17 / \mathrm{ft}^{2}$ to $\$ 0.84 / \mathrm{ft}^{2}$ $\left(\$ 12.59 / \mathrm{m}^{2}\right.$ to $\left.\$ 9.15 / \mathrm{m}^{2}\right)$. The third year Base case, simulated with third year site weather data, predicts the energy cost intensity of a conventional code compliant building would have $\$ 1.29 / \mathrm{ft}^{2}\left(\$ 13.89 / \mathrm{m}^{2}\right)$. Compared to this benchmark, the energy cost savings for the third year was $35 \%$. These savings should increase because the demand charges during April and May $2002(157.8 \mathrm{kVA}$ and $183.6 \mathrm{kVA})$ were unnecessarily high due to the testing and commissioning of the backup electric boiler during the heat pump upgrade. Based on typical peak demands for April and May of 2002 (66 kVA), the energy costs savings would have approached $50 \%$. 


\section{Subsystem Evaluations}

\subsection{Wastewater Treatment Energy Use}

During the evaluation period, the wastewater treatment process loads (water pumps, water treatment equipment, and exhaust fans) were independently monitored. From March 2001 through February 2002, these equipment process loads accounted for $10 \%$ of the total annual building energy consumption, or $12,438 \mathrm{kWh}(44,776 \mathrm{MJ})$. As this wastewater treatment system is considered a laboratory research tool for the students enrolled in the Environmental Studies Program, it is important to document the energy performance of the Lewis Center without the on-site wastewater treatment process loads. Typical academic and commercial buildings do not process wastewater on-site. By documenting and comparing the Lewis Center energy use without the wastewater treatment system, a better comparison to typical buildings can be made.

The heating requirements for the wastewater treatment sunspace and the exhaust air rates are a result of the requirements of the wastewater treatment operation. These loads were not separately monitored because a flow meter was not planned for this portion of the hydronic loop. The power requirements for the fan can be measured, but a more significant impact is the conditioning of the air drawn from the rest of the building. As a result, this study used a calibrated model based on the second year of results to study the energy impacts of this system on the building. The total loads for the wastewater treatment include the heating load for the space, the lighting load, the pumps, the fans, and the energy to condition the air that is drawn through the main portion of the building.

To investigate the full energy requirements of the wastewater treatment space, the calibrated as-built building models were simulated without the wastewater treatment sunspace. These simulations were created by removing the $750-\mathrm{ft}^{2}\left(70 \mathrm{~m}^{2}\right)$ sunspace and all related equipment, water treatment process loads, lighting, ventilation, and heating loads from the calibrated As-built March 01-February 02 model. The Lewis Center energy performance was calibrated without this sunspace with TMY2 weather. Without including the water treatment process loads, the related wastewater treatment equipment and lighting, and the expected space heating and ventilation loads, would have consumed $29 \%$ less energy than the calibrated As-built March 01-February 02 model for a typical weather year. This number results in a site consumption intensity of $28.2 \mathrm{kBtu} / \mathrm{ft}^{2} \cdot \mathrm{yr}\left(320 \mathrm{MJ} / \mathrm{m}^{2} \cdot \mathrm{yr}\right.$ ) (of which $61 \%$ would have been met by $\mathrm{PV}$ production). The simulated energy requirement of the wastewater treatment and $750-\mathrm{ft}^{2}\left(70-\mathrm{m}^{2}\right)$ sunspace was 43,799 kWh/yr (157,676 MJ/yr) using TMY2 with second year as-built operation. The energy requirements of treating wastewater on-site, in this case, have a significant affect on the energy performance of the Lewis Center.

Throughout the evaluation period, NREL attempted to limit unnecessary energy use due to this space. The heating set point was reduced from $70^{\circ} \mathrm{F}\left(21^{\circ} \mathrm{C}\right)$ to $50^{\circ} \mathrm{F}\left(10^{\circ} \mathrm{C}\right)$ and the electric boiler was replaced with heat pumps. To determine the third-year energy performance without the wastewater treatment, NREL simulated the As-built March 02-February 03 third-year model without the wastewater treatment loads. The site energy use intensity would have been $22.5 \mathrm{kBtu} / \mathrm{ft}^{2} \cdot \mathrm{yr}\left(256 \mathrm{MJ} / \mathrm{m}^{2} \cdot \mathrm{yr}\right)$ without this $750-\mathrm{ft}^{2}$ $\left(70-\mathrm{m}^{2}\right)$ space, with PV production meeting $76 \%$ of the load. For the third year of operation, this space was responsible for $24,881 \mathrm{kWh}(89,572 \mathrm{MJ} / \mathrm{yr})$, or $23 \%$ of the energy used at the Lewis Center based on TMY2 weather. Further discussion of this and recommendations for efficient exhaust control of the wastewater treatment space are included in Section 7.2.

The energy requirements for the wastewater treatment process loads were shown to be comparable to conventional wastewater treatment systems (Brix 1999). The same study determined that the energy requirements for the wastewater treatment systems are increased significantly in cold climates where the aquaculture system needs to be placed in a heated sunspace, as in the case with the Lewis Center's wastewater treatment. The heating load of the wastewater treatment space significantly reduced the 
energy performance of the building. By addressing some of these heating inefficiencies, Oberlin College has reduced the impact of the wastewater treatment on the whole-building energy performance of the Lewis Center.

\subsection{HVAC Performance Evaluation}

By evaluating the whole-building annual energy performance, NREL determined that HVAC was responsible for $59 \%$ of the total energy consumed in the building during the second year of occupancy. To further understand HVAC energy performance, Figure 6-1 was developed, an X-Y plot of the daily total HVAC electricity use from March 1, 2001, through February 28, 2002, versus the corresponding average daily outdoor temperature.

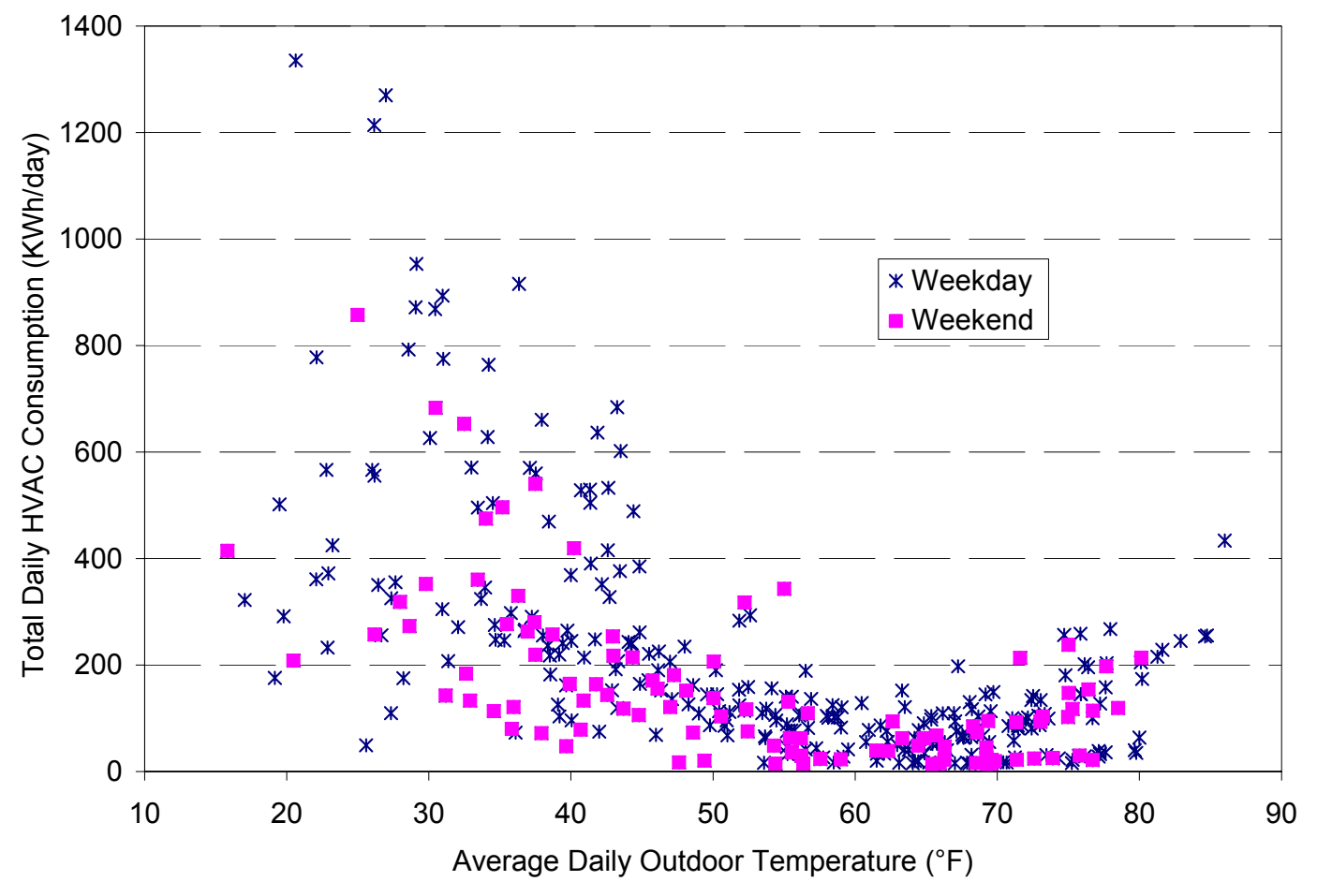

Figure 6-1 Daily HVAC energy consumption versus average outdoor temperature

Weekends and weekdays are shown separately to see whether this can explain the HVAC electricity use variations over a constant average daily outdoor temperature. Variations in weekday and weekend occupancy did not dramatically affect the HVAC consumption at a constant outdoor temperature, although it was evident that the peak heating days are not weekend days. The graph also demonstrates that for average outdoor temperatures greater than $50^{\circ} \mathrm{F}\left(10^{\circ} \mathrm{C}\right)$ and less than $70^{\circ} \mathrm{F}\left(21^{\circ} \mathrm{C}\right)$, the total daily HVAC consumption was typically less than $175 \mathrm{kWh}(630 \mathrm{MJ})$ per day. Figure 6-1 also shows that the Lewis Center is a heating-dominated building and that controlling heating loads offers the greatest potential for energy savings. This finding is also true for the power demand. The hydronic system and peak demand affects on energy performance were discussed in Section 5.2.3.2.

As discussed in the previous section, the wastewater treatment was responsible for a significant portion of the hydronic load in the Lewis Center. The atrium space was also one of the primary heating zones in the hydronic loop. The first step to limit the energy use in the atrium was to heat the space with HP-4 and not the radiant floor. This reduced the use of the inefficient electric boiler EB-1. The heating set point was also reduced to further limit the energy use to the atrium. Replacing EB-1 with heat pumps also 
addressed the high energy use of the hydronic system. Further analysis of the As-built March 02-February 03 model shows that the atrium space was responsible for $26 \%$ of the annual HVAC load. The heating load imposed by atrium windows was $34 \%$ of the total heating load in the atrium. The conduction losses through the triple pane glass and aluminum frames, combined with offsetting solar gains, resulted in the highest heating load in the space, as shown in Figure 6-2. The solar gains predicted by the DOE-2 model imply a significant passive solar contribution to the heating of the atrium. Further work is needed to fully evaluate the passive solar design of the Lewis Center. Potential passive solar design issues to consider include: How would the atrium heating system perform if the south curtain wall did not have such a low SHGC, and what if the East curtain wall was opaque, and what if portions of the south glazing area are replaced by insulating panels?

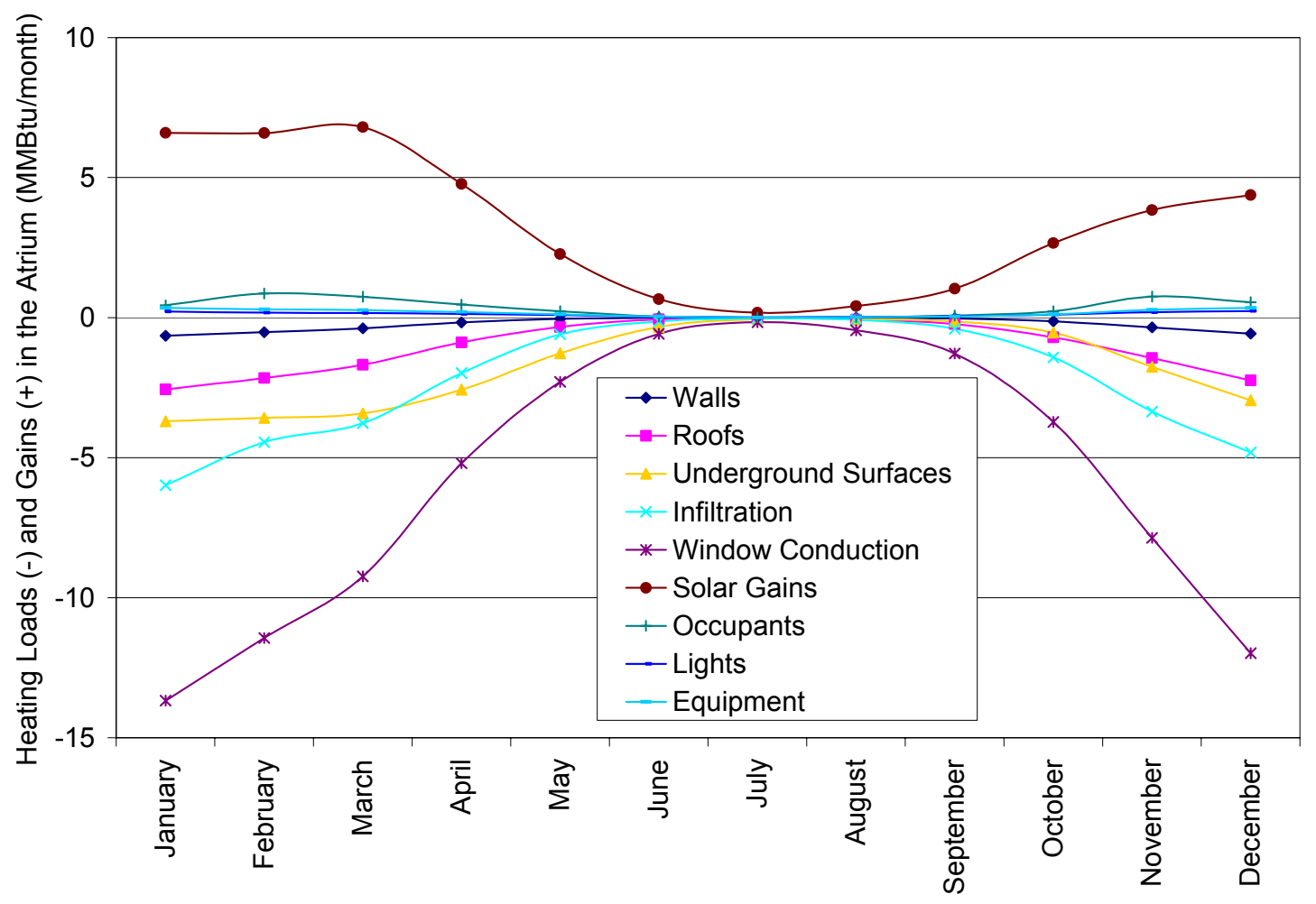

Figure 6-2 Simulated atrium heating loads and gains

The outdoor air to the classrooms and offices is controlled by occupancy sensors. The control sequence is as follows: When one of these spaces becomes occupied, if there is insufficient daylight present, the room's lighting system is turned on. The outdoor air supply damper opens 50 percent and if the measured air temperature is outside the programmed setting, the thermostat commands on the room console heat pump. When the outdoor air damper opens, HP-5, a 6.5 -ton $(22.2 \mathrm{~kW})$ capacity heat pump, turns on, which, in turn, turns on the ERV-2 ventilation system with its $2500 \mathrm{cfm}(1,180 \mathrm{~L} / \mathrm{s})$ outdoor air supply fan and its $1350 \mathrm{cfm}(637 \mathrm{~L} / \mathrm{s})$ exhaust fan. Turning on HP-5 turns on a variable speed ground water loop pump and if the entering water temperature from the ground loop is less than $40^{\circ} \mathrm{F}\left(4.4^{\circ} \mathrm{C}\right)$, the $112 \mathrm{~kW}$ electric boiler EB-2 is turned on as well. The use of all this ventilation air equipment could be reduced by utilizing the existing $\mathrm{CO}_{2}$ sensors. Each classroom already has a $\mathrm{CO}_{2}$ sensor. We recommend the following outdoor air control sequence: operate room dampers based on exceeding the $\mathrm{CO}_{2}$ settings in a classroom. Set the damper to $50 \%$ open when $\mathrm{CO}_{2}$ exceeds the set point. Use $100 \%$ setting when $\mathrm{CO}_{2}$ exceeds the set point by 100 parts per million. Control outside air fan based on the position of these dampers in addition to a weekday schedule for the offices. If no zones need outside air, the fan, ERV, and HP-5 should not operate. 
Combined with controlling ventilation based on demand with $\mathrm{CO}_{2}$ levels, an outdoor air economizer could further reduce HVAC loads. The controls of HP-5, the ERV-2 fans, and enthalpy wheel motor would have to be separated so that outdoor air can be supplied during favorable economizer conditions. Economizer operation would require operation of the fans in HP-5 and ERV-2 without using the mechanical cooling or heating in HP-5 or the energy recovery wheel in ERV-2. The outdoor ventilation system for the classrooms and offices should also be operated in stages based on whether the building is heating or cooling. When the building is in cooling mode and the outdoor temperature is less than the inside temperature, the ERV-2 fans should be used as an economizer for the classroom and office spaces. If these spaces need fresh air, use the ERV-2 fans to bring fresh air for stage 1. If the outdoor air is too humid, use HP-5 to dry out the air (mechanical cooling). When HP-5 is off, the bypass damper should be open. If supply air temperature is above $70^{\circ} \mathrm{F}\left(21^{\circ} \mathrm{C}\right)$, use HP-5 to cool down the air. If the supply air is less than $55^{\circ} \mathrm{F}\left(13^{\circ} \mathrm{C}\right)$, use $\mathrm{HP}-5$ to heat the air.

\subsubsection{Energy Recovery Ventilators}

To determine the general installed performance of the exhaust energy recovery (ERV) units, air temperatures on the supply ( $\mathrm{T}_{\mathrm{OA}}$ and $\left.\mathrm{T}_{\mathrm{OAS}}\right)$ and exhaust sides $\left(\mathrm{T}_{\mathrm{RA}}\right.$ and $\left.\mathrm{T}_{\mathrm{EA}}\right)$ of $\mathrm{ERV}-1$ and $\mathrm{ERV}-2$ were measured, as shown in Figure 6-3. These measurements were made with thermocouples located in the air ducts.

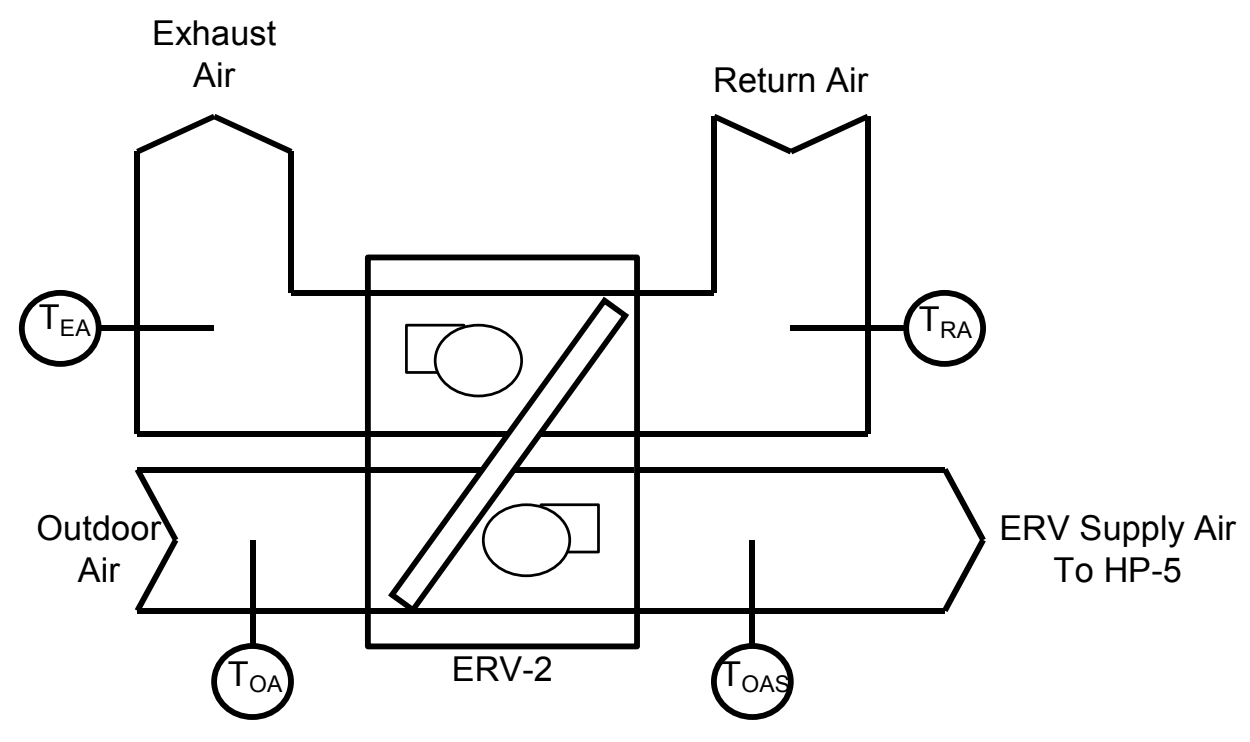

Figure 6-3 ERV-2 air temperature measurements

The amount of sensible energy exchanged between the return air and the supply air by the energy recovery wheel is expressed as $Q_{S}$ in Equation 6-1.

$$
Q_{S}=\left|\dot{m}_{S} \cdot c_{p}\left(T_{O A S}-T_{O A}\right)\right|=\left|\dot{m}_{R} \cdot c_{p}\left(T_{R A}-T_{E A}\right)\right|
$$


where:

$$
\begin{array}{ll}
T_{O A} & =\text { outdoor air dry-bulb temperature entering supply side of ERV } \\
T_{O A S} & =\text { supply air dry-bulb temperature } \\
T_{R A} & =\text { return air dry-bulb temperature } \\
T_{E A} & =\text { exhaust air dry-bulb temperature } \\
c_{p} & =\text { specific heat of return and supply air } \\
\dot{m}_{S} & =\text { mass-flow rate of the supply air } \\
\dot{m}_{R} \quad=\text { mass-flow rate of return air. }
\end{array}
$$

The power requirements of the supply fan, return fan, and enthalpy wheel in ERV-2 were $1.7 \mathrm{~kW}$. To calculate the recovered energy, supply airflow of $3300 \mathrm{cfm}\left(1.6 \mathrm{~m}^{3} / \mathrm{s}\right)$ was used in Equation $6-1$. As Figure 6-4 shows, the unit uses more energy than it recovers when the outdoor temperatures are between $70^{\circ} \mathrm{F}$ and $87^{\circ} \mathrm{F}\left(21^{\circ} \mathrm{C}-31^{\circ} \mathrm{C}\right)$. A portion of the $1.7 \mathrm{~kW}$ that the supply fan motor and enthalpy wheel motor of ERV-2 consumes is directly added to the supply air in the form of heat, because these motors are located in the supply air duct. This motor placement is beneficial during the heating season, as the heat from the motors is directly added to the supply air stream. During the cooling season, this added motor heat counteracts the cooling energy recovered from the exhaust air. When heat is added to the recovered cooling energy supply, it is only possible to recover more cooling energy than is required to operate ERV-2 at outdoor temperatures greater than $87^{\circ} \mathrm{F}\left(31^{\circ} \mathrm{C}\right)$.

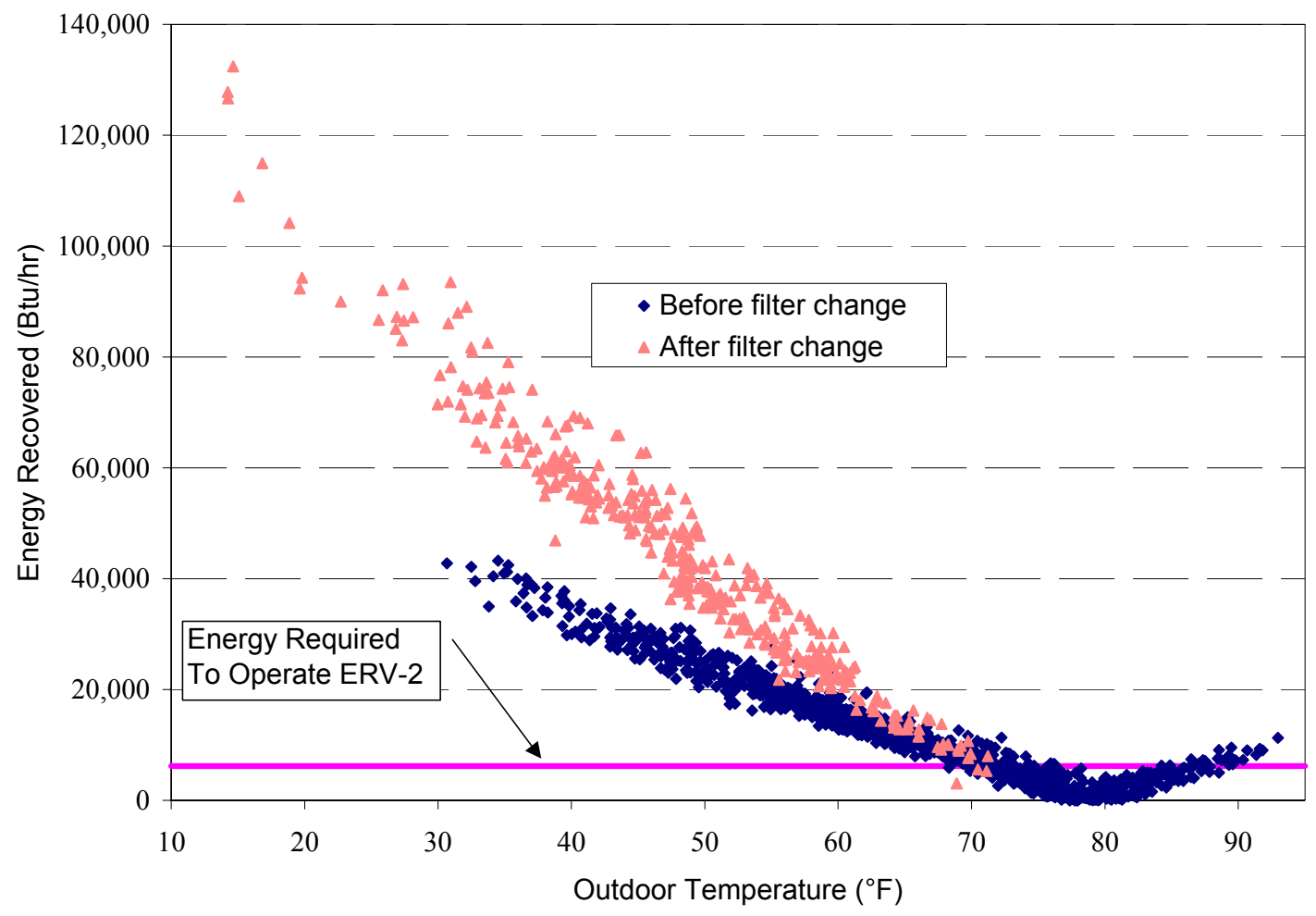

Figure 6-4 Calculated ERV-2 energy recovery as a function of outdoor temperature

The supply airflow rate of $3300 \mathrm{cfm}\left(1.6 \mathrm{~m}^{3} / \mathrm{s}\right)$ was hand-measured on September 20, 2001. Due to the ductwork configuration, it could only be estimated. The DOE-2 energy analysis also assumes ideal flow (equal inlet and exhaust). These are the minimum operating dead bands. During these measurements, the 
filters were inspected on both the supply and return of this unit. The filters were clogged with dirt and had dislodged from the filter rack. They were damaged from rubbing on the energy recovery wheel. Because access to the ERV-2 filters was obstructed, they were not maintained or changed until October 2001. A possible explanation for lack of maintenance was poor accessibility of the filters. Figure 6-5 shows one of the damaged air filters.

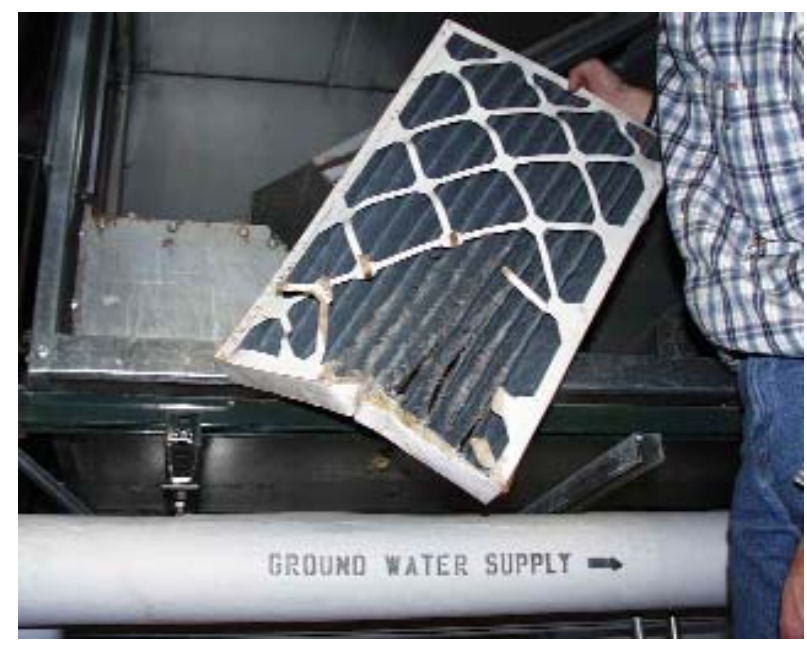

Figure 6-5 Damaged ERV filter

The ERV is rated to transfer both sensible and latent energy between the air streams with an effectiveness of 83\% (Greenheck 2003). Figure 6-6 shows the expected ERV performance for typical heating and cooling conditions.

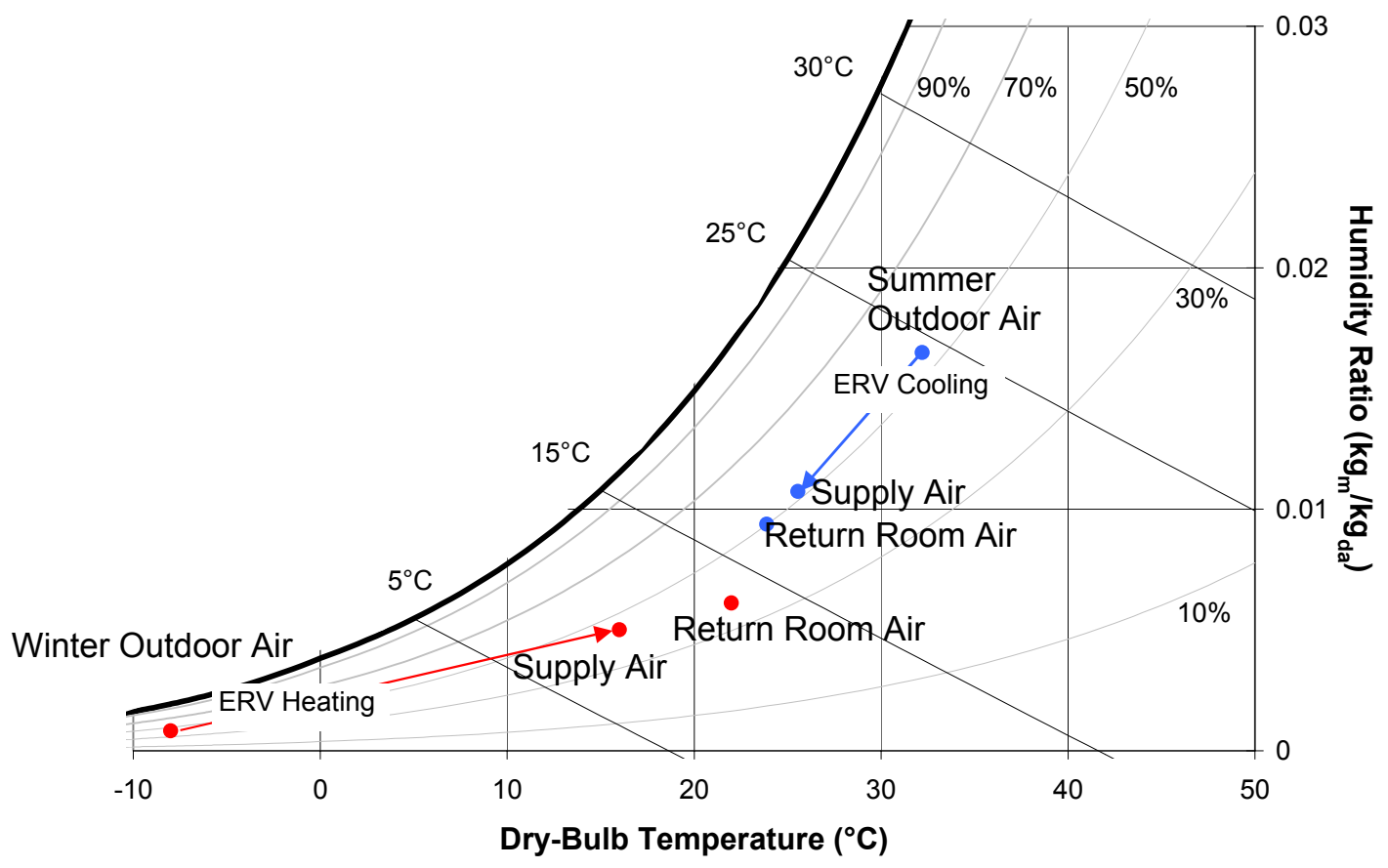

Figure 6-6 Published ERV performance (Greenheck 2003) 
On cold days when outdoor temperatures is $17^{\circ} \mathrm{F}\left(-8.3^{\circ} \mathrm{C}\right)$ and the return room air is $72^{\circ} \mathrm{F}\left(22^{\circ} \mathrm{C}\right)$, the ERV effectiveness is $80 \%$ with a balanced supply and return airflow. Supply air is preconditioned the supply air to $61^{\circ} \mathrm{F}\left(16^{\circ} \mathrm{C}\right)$. Similarly, for a cooling day with $90^{\circ} \mathrm{F}\left(32^{\circ} \mathrm{C}\right)$ dry-bulb and $76^{\circ} \mathrm{F}\left(24^{\circ} \mathrm{C}\right)$ wetbulb outdoor temperatures and $75^{\circ} \mathrm{F}\left(24^{\circ} \mathrm{C}\right)$ dry-bulb and $62.5^{\circ} \mathrm{F}\left(16.9^{\circ} \mathrm{C}\right)$ wet-bulb return room temperatures, the ERV effectiveness is $80 \%$ with a preconditioned supply air of $78^{\circ} \mathrm{F}$ dry bulb $\left(26^{\circ} \mathrm{C}\right)$ and $65^{\circ} \mathrm{F}$ wet bulb $\left(18.6^{\circ} \mathrm{C}\right)$.

Equation 6-2 was used to calculate the ERV sensible effectiveness, $\varepsilon$ (ASHRAE 1991).

$$
\varepsilon=\frac{\dot{m}_{S}\left(T_{O A}-T_{O A S}\right)}{\dot{m}_{R}\left(T_{O A}-T_{R A}\right)}
$$

The mass-flow ratio between supply air and return air the measured air temperatures.

was determined from Equation 6-1 and

From October 18, 2001 to March 1, 2002 (after the filters were changed), the calculated sensible effectiveness of ERV-2 was estimated to be $92 \%$. The calculated effectiveness was averaged over all hours and conditions that the ERV operated during this time. The estimated recovery effectiveness is greater than the rated effectiveness because of a greater measured mass-flow ratio between supply air and return air. Note that the measured effectiveness increases as mass-flow ratio increases. The measured mass-flow ratio was between 1.4 and 2.0, while the rated effectiveness assumes a balance between supply and return (mass-flow ratio of 1.0).

NREL also considered the overall recovery effectiveness between the total building exhaust and supply, assuming rated ERV recovery effectiveness and flow rates. The separate exhaust fans in the wastewater treatment, bathrooms, kitchen, and mechanical rooms are rated to exhaust conditioned room air directly outside; this accounts for up to $3,345 \mathrm{cfm}\left(1.579 \mathrm{~m}^{3} / \mathrm{s}\right)$ without any energy recovery. These exhaust fans create an airflow imbalance in the ERV, diminishing total building recovery capacity. Based on a balance of rated supply and exhaust flows into and out of the building, only half of the potential return air is exhausted through the energy recovery units. The room air that is exhausted through the wastewater treatment, kitchen, and bathrooms has a recovery effectiveness of 0.0 , resulting in a total building exhaust recovery effectiveness of $46 \%$ at rated air flows and recovery effectiveness.

Although ERV-1 was similarly monitored, NREL did not consider the effectiveness of this unit because the return air is typically mixed with the supply air, effecting the supply air temperature measurement. The measured effectiveness of ERV-2 was expected to be similar to ERV-1. As previously discussed, the sensible ERV effectiveness in the uncalibrated DOE-2 models was assumed to be $80 \%$.

At a component level, the manufacturer's rating was used to represent the actual operation of ERV-1 and ERV-2. There were concerns regarding exhaust air that is not exhausted through the energy recovery units. Recommendations to limit unrecovered exhaust air are included in Section 7.

\subsubsection{Ground Source Heat Pump Loop}

The primary purpose for this heat pump evaluation was to determine the reduction in capacity and COP due to the ARI-320 rated heat pumps operating at typical ground source entering water temperatures (EWT). The concern was the as-built heat pumps were not rated for ground source EWT, potentially reducing capacity. As the rated performance of the water source heat pumps primarily depends on the water temperature entering the heat pumps (EWT), the distribution of EWT is considered in Figure 6-7. In addition, the return water loop temperature was measured where the water enters the ground. 


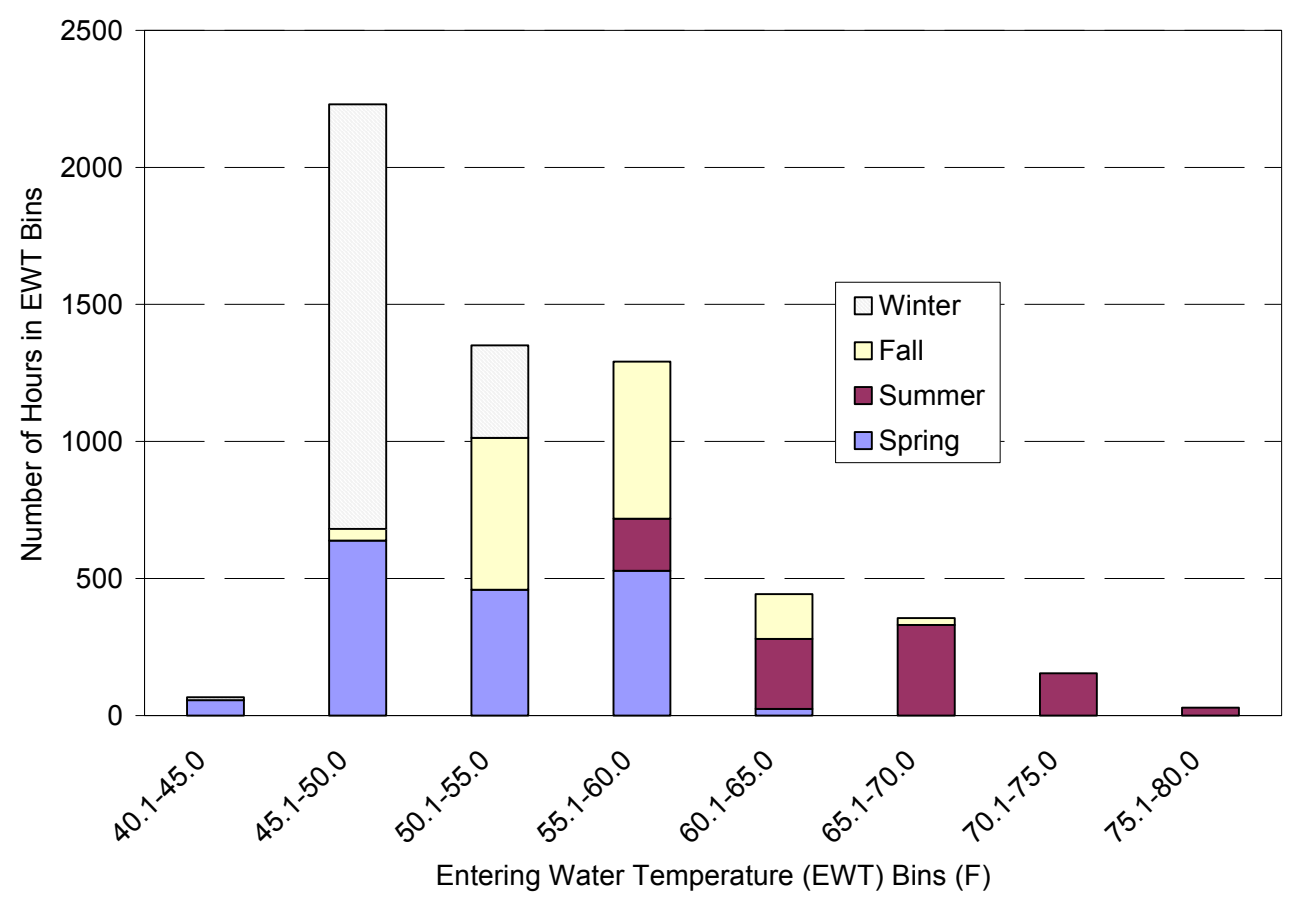

Figure 6-7 Frequency of hourly average EWT from the ground loop

The EWT was considered for hours when HP-4, HP-5, or the console heat pumps were operating. There was at least one heat pump operating for $1 \mathrm{hr}$ for $68 \%$ of the evaluation period. This was determined when at least $0.6 \mathrm{kWh}$ was consumed by these heat pumps during any given hour. During the hours of heat pump operation, the EWT was between $45^{\circ} \mathrm{F}\left(7.2^{\circ} \mathrm{C}\right)$ and $60^{\circ} \mathrm{F}\left(16^{\circ} \mathrm{C}\right)$ for $82 \%$ of the heat pump operational hours over the year. The minimum EWT was $44^{\circ} \mathrm{F}\left(6.7^{\circ} \mathrm{C}\right)$ and the maximum was $79^{\circ} \mathrm{F}$ $\left(26^{\circ} \mathrm{C}\right)$ (based on hourly averaged temperatures). The maximum EWT occurred on August 9, 2001, during a peak cooling period. The heating and cooling COP as a function of EWT are specified by the manufacturer and graphed in Figure 6-8 (Carrier 2003). The heating and cooling efficiency of the larger HP-5 is lower than HP-4 over the rated EWT range. 


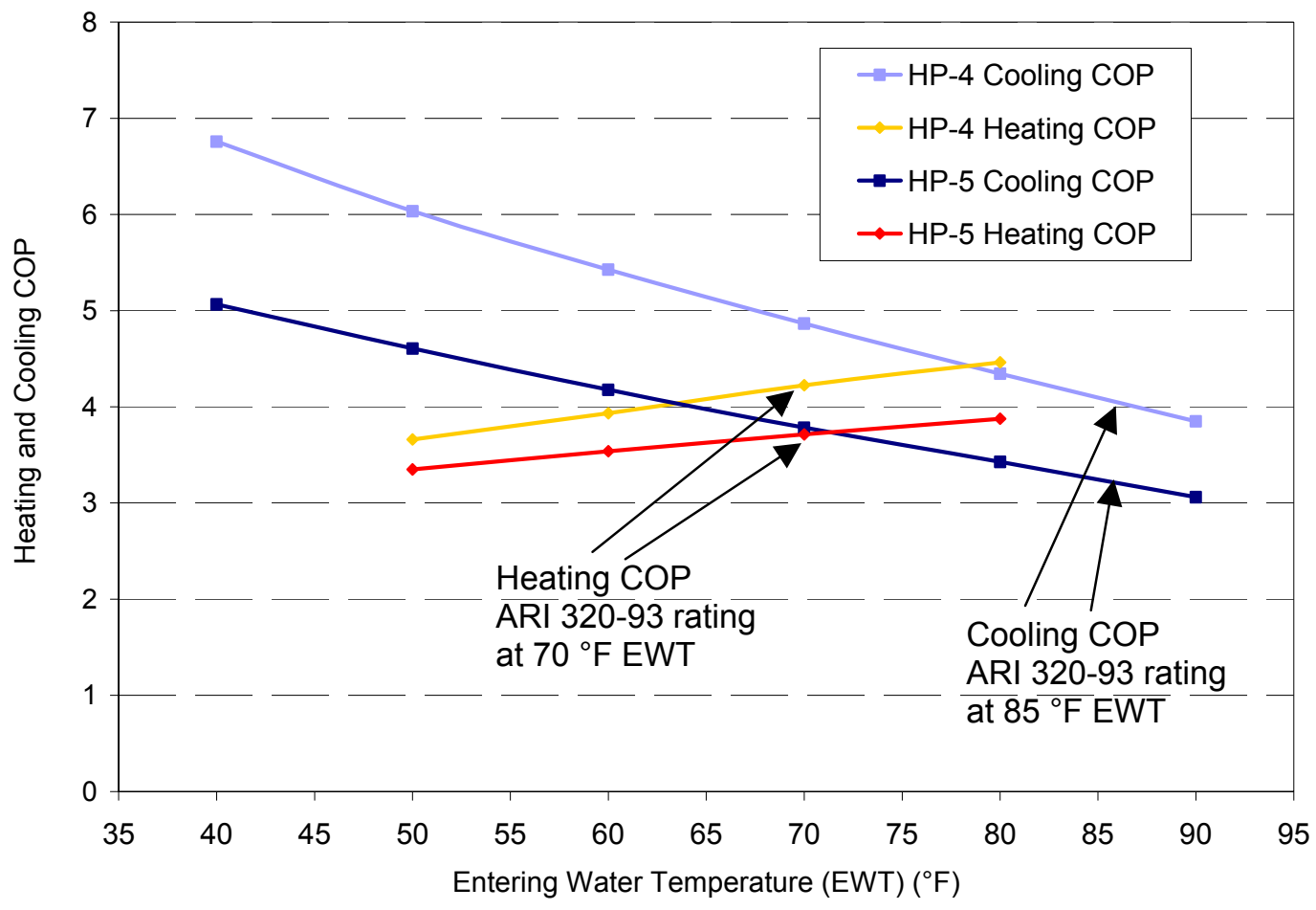

Figure 6-8 HP-4 and HP-5 published heating and cooling performance

The ARI-320 standard rates the heat pump heating performance at $70^{\circ} \mathrm{F}\left(21^{\circ} \mathrm{C}\right)$ EWT and the cooling performance at $85^{\circ} \mathrm{F}\left(29^{\circ} \mathrm{C}\right) \mathrm{EWT}$. HP-4 cooling performance is rated at $4.1 \mathrm{COP}$; HP-5 is rated at 3.3 COP. The heating performance for HP-4 is rated at 4.2 COP, and HP-5 is rated at 3.8 COP. As Figure 6-7 showed, the heat pump loop typically did not operate in the EWT ARI-320 standard range.

The distribution of heating and cooling efficiencies was determined and graphed as histograms in Figure 6-9 and Figure 6-10. The distributions are based on the rated heating and cooling performance as a function of the measured EWT. The heat pump performance is not directly measured due to difficulties in field evaluation of in-situ heat pump performance. The expected heat pump performance is based on measured source temperatures and manufacturer's performance ratings at these temperatures. This heat pump performance assessment was also based on the assumption that the installed heat pumps were operating according to specifications. The expected heating and cooling performances of HP-4 and HP-5 were determined for the hours that each heat pump unit operated in heating and in cooling mode. The expected heating and cooling COP distribution was then calculated based on the total annual operational time in heating and cooling mode. 


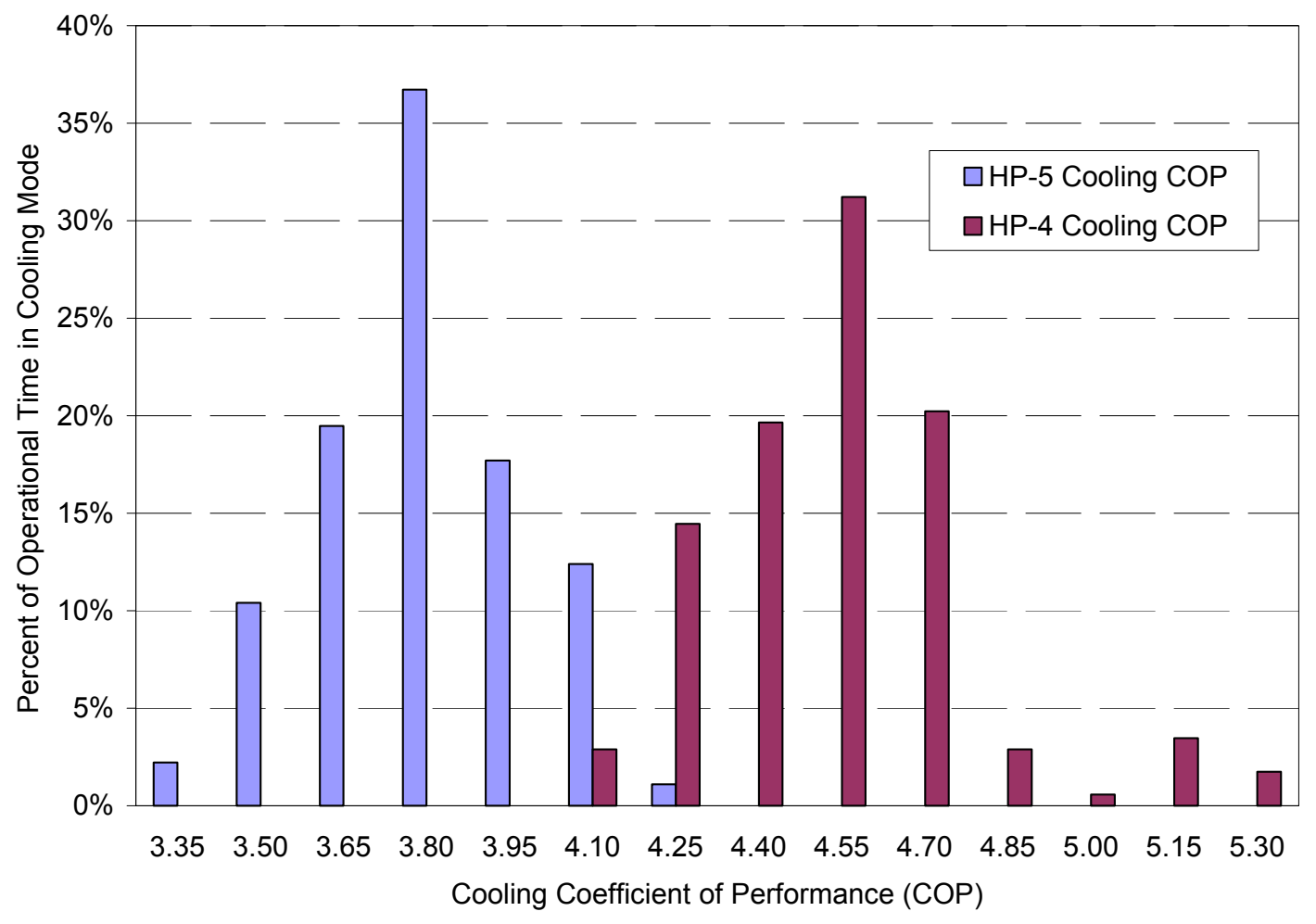

Figure 6-9 HP-4 and HP-5 expected cooling performance

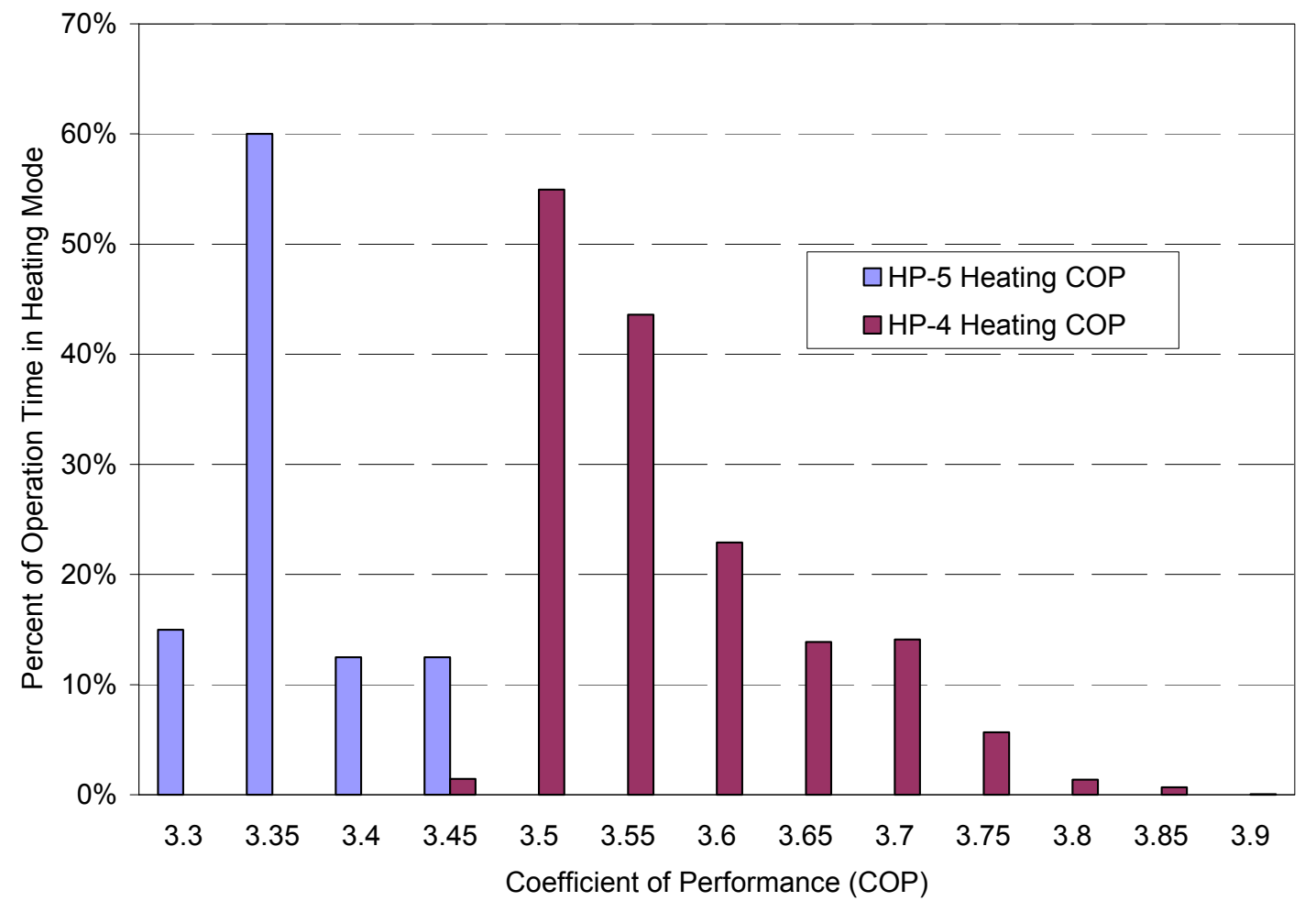

Figure 6-10 HP-4 and HP-5 expected heating performance 
With the cooling COP rated at $85^{\circ} \mathrm{F}\left(29^{\circ} \mathrm{C}\right)$ EWT and the typical measured EWT operational range from $45^{\circ} \mathrm{F}$ to $60^{\circ} \mathrm{F}\left(7.2^{\circ} \mathrm{C}\right.$ to $\left.16^{\circ} \mathrm{C}\right)$, the expected cooling COP for HP-4 and HP-5 was generally $9-13 \%$ higher than the rated cooling COP. Conversely, when the heating COP was rated at $70^{\circ} \mathrm{F}\left(21^{\circ} \mathrm{C}\right) \mathrm{EWT}$, the expected heating COP for HP-4 and HP-5 was generally $12-17 \%$ less than the rated COP. NREL found a similar reduction in expected heating and cooling capacities as compared to the rated capacities. As the EWT during the heating season was typically on the low end or out of the recommend range of these standard range heat pumps, the heat pump heating system often operated at a reduced capacity and COP. The consequences of operating at the low end of the rated EWT, as compared to extended range heat pumps, are discussed in Section 7.

Similar performance distributions as a function of EWT for the console heat pumps were not calculated because each console heat pump was not monitored separately. NREL expected that the heating and cooling performance of the console heat pumps would be similar to HP-4 and HP-5 because the console heat pumps are also rated by ARI-320 standards. An annual performance comparison to ground source rated (ARI-330) heat pumps is given in Section 7.

\subsection{PV System Evaluation}

\subsubsection{PV System Evaluation Methods}

NREL monitored the performance of the PV system, with meter types and locations as shown in Figure 6-11 and Table 6-1. Additional PV performance measurements include PV cell temperature at $-3.0^{\circ}, 0.0^{\circ}$, and $3.0^{\circ}$ tilt angles of subarray $\mathrm{A}$, horizontal and vertical insolation, and outdoor weather conditions. The NREL and Oberlin College monitoring team has been collecting minute and hourly data since March 1, 2001.

Table 6-1 PV System Metered Data Points

\begin{tabular}{|l|l|}
\hline \multicolumn{1}{|c|}{ Meter Labels } & \multicolumn{1}{|c|}{ Label in Figure 6-11 } \\
\hline \hline PV DC current and voltage for each subarray & ShVd1, ShVd2, ShVd3 \\
\hline PV AC power produced & WM 11 \\
\hline AC power used by the PV system during inverter standby mode (back feed) & WM 20 \\
\hline PV AC power exported to the utility & CM 1 \\
\hline Total AC power purchased from the utility & CM 2 \\
\hline Total AC power consumed in the building & WM 4-WM 21 \\
\hline
\end{tabular}




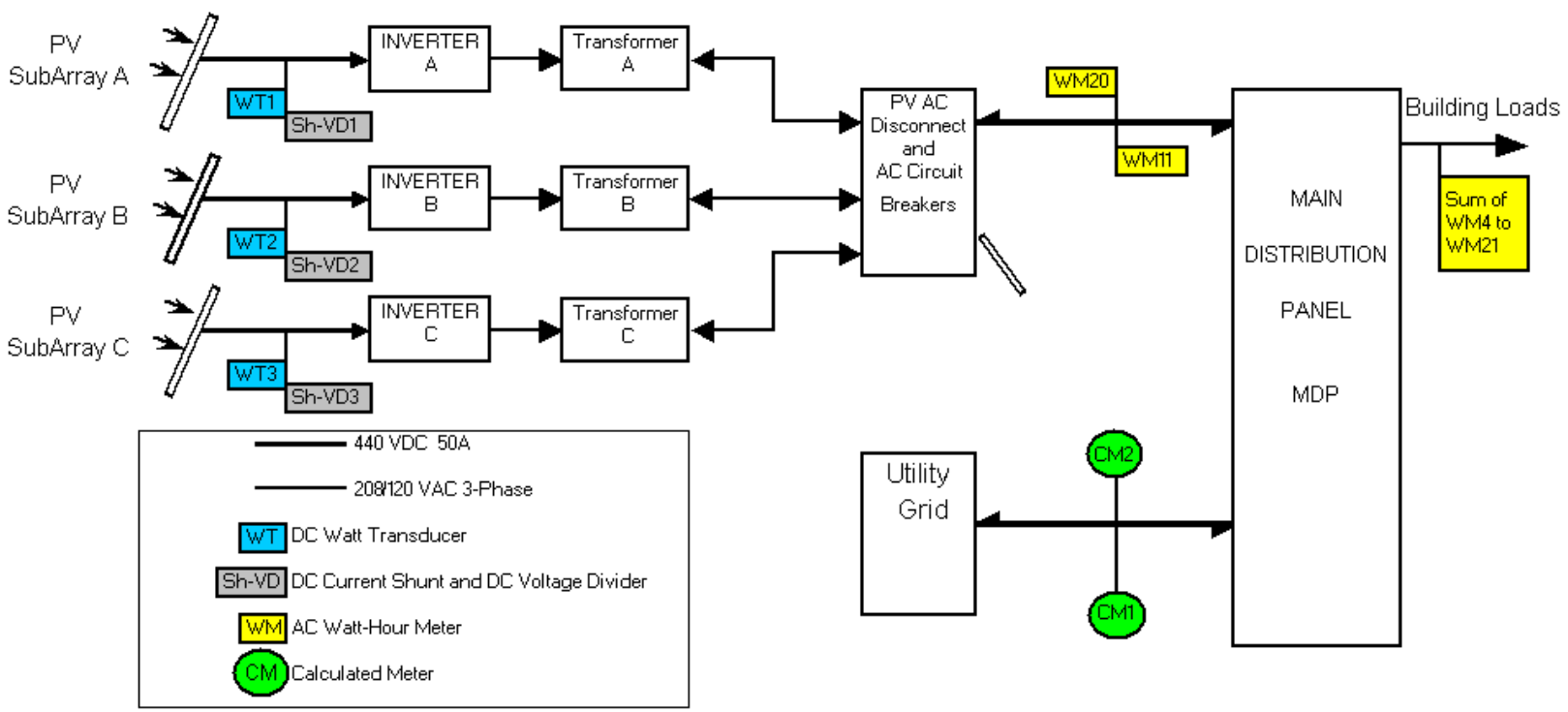

Figure 6-11 Single-line PV electrical system plan and data acquisition meter locations

\subsubsection{PV System Simulations}

The PV system simulation tool, PVSyst v3.2 (Mermoud 1996), was used to calculate the expected annual performance of the Lewis Center's PV system. Inputs to this model include PV panel size and manufacturer, array wiring configuration and associated losses, array tilt and azimuth, hourly weather data, and inverter size and type. System specific inputs, such as isolation transformer losses and array wiring losses, are discussed in Section 6.3.2. The model predictions, simulated using measured site weather data, were verified with measured production. TMY2 weather data for Cleveland Hopkins Airport was used to model the expected annual performance. An average array tilt angle of $8^{\circ}$ was modeled as a representation of the multiplane array. A discussion of this assumption is discussed in Section 6.3.2.

A second model used was the Sandia Photovoltaic Performance I-V Curve Tracer (King et al. 1998). The purpose of the curve trace analysis was to evaluate the effects of operating voltage on PV production. The evaluators used this model to create current-voltage (I-V) and power-voltage $(\mathrm{P}-\mathrm{V})$ curve traces for a complete subarray at varying cell temperatures and insolation levels. With a specified array wiring configuration and the manufacturer's PV panel ratings at standard test conditions of $1000 \mathrm{~W} / \mathrm{m}^{2}$ and $77^{\circ} \mathrm{F}$ $\left(25^{\circ} \mathrm{C}\right)$ cell temperature, expected I-V and P-V curve traces were generated with the Sandia I-V Curve Tracer model and compared to measured curve traces.

\subsubsection{PV System Evaluation Results}

To determine the possible sources of PV performance degradation, NREL performed a full system evaluation and verification. Figure 6-12 compares the measured PV performance and the results from PVSyst simulation model using 2001-2002 measured weather data. The comparison of daily average PV production by month shows some discrepancies between the modeled and the actual PV performance. As shown in Table 6-2, the total measured AC PV production from March 2001 through February 2002 was $59,518 \mathrm{kWh} / \mathrm{yr}(214,260 \mathrm{MJ} / \mathrm{yr})$. Each category listed in Table 6-2 is discussed later in this section. The projected annual AC PV production was $63,915 \mathrm{kWh} / \mathrm{yr}(230,090 \mathrm{MJ} / \mathrm{yr})$ when simulated with actual site weather data. This is $7 \%$ or $4,397 \mathrm{kWh} / \mathrm{yr}(15,830 \mathrm{MJ} / \mathrm{yr})$ more than the measured annual output over the evaluation period. 


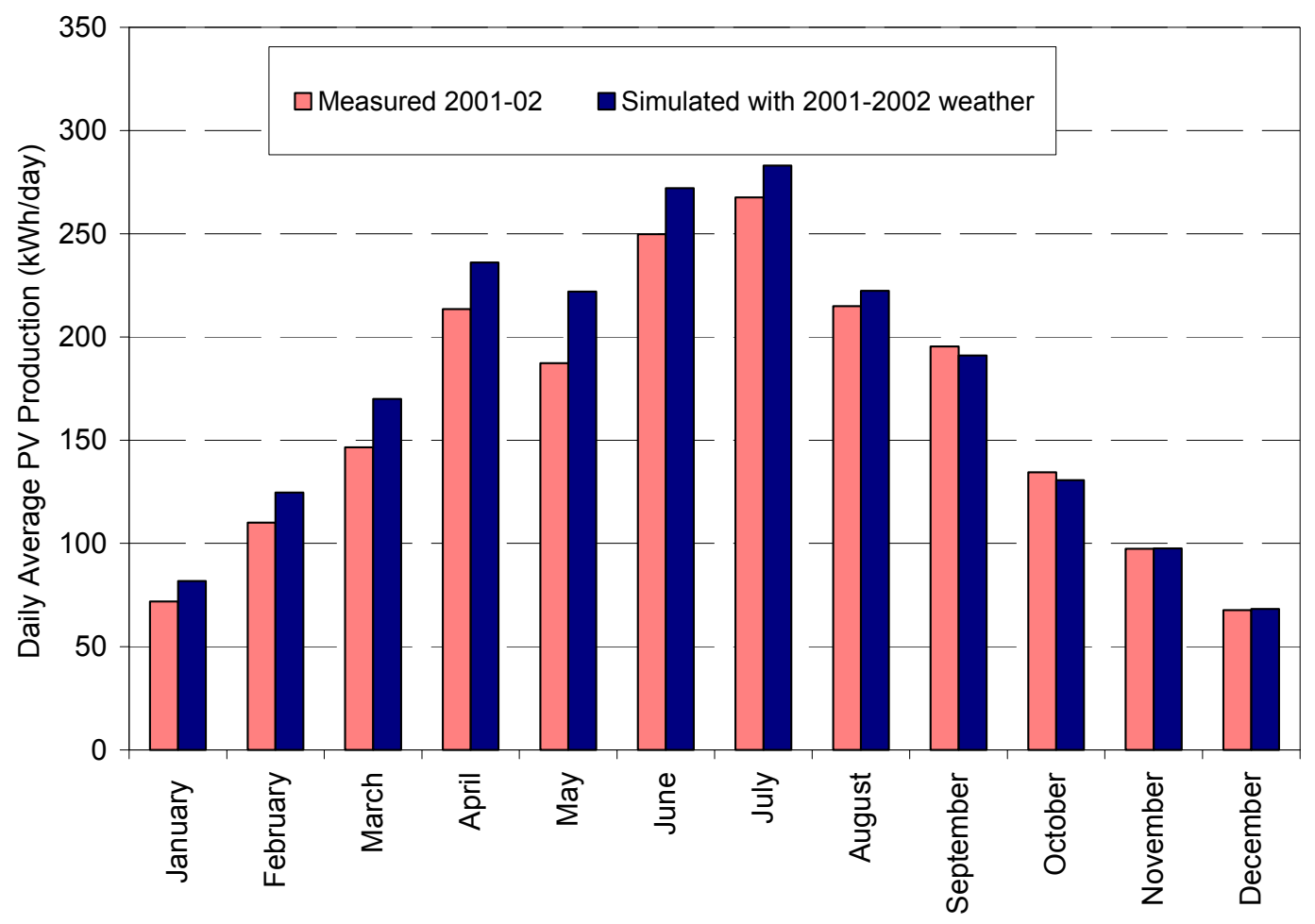

Figure 6-12 Measured versus simulated daily average PV production, March 1, 2001 through February 28, 2002 
Table 6-2 Measured PV Performance Summary, March 1, 2001 through February 28, 2002

\begin{tabular}{|c|c|c|c|c|c|c|c|c|c|c|c|c|c|}
\hline & Mar-01 & Apr-01 & May-01 & June-01 & July-01 & Aug-01 & Sept-01 & Oct-01 & Nov-01 & Dec-01 & Jan-02 & Feb-02 & $\begin{array}{c}\text { Annual } \\
\text { Totals/Peaks }\end{array}$ \\
\hline Total PV Production (KWh) & 4535 & 6396 & 5798 & 7481 & 8283 & 6653 & 5852 & 4161 & 2918 & 2093 & 2273 & 3078 & 59519 \\
\hline$\%$ of Building Load Met By PV & 17.5 & 63.6 & 70.8 & 149.0 & 106.8 & 88.3 & 80.3 & 55.2 & 35.4 & 21.4 & 18.9 & 23.4 & 48.7 \\
\hline $\begin{array}{l}\text { Total Global Horizontal } \\
\text { Insolation }\left(\mathrm{MWh} / \mathrm{m}^{2}\right)\end{array}$ & 103 & 149 & 153 & 186 & 199 & 156 & 124 & 82 & 56 & 40 & 46 & 65 & 1358 \\
\hline $\begin{array}{l}\text { Peak Hourly AC PV Production } \\
\text { (kW) }\end{array}$ & 45.2 & 44.6 & 44.2 & 42.6 & 43.3 & 40.5 & 41.2 & 38.5 & 30.9 & 27.4 & 29.9 & 36.5 & 45.2 \\
\hline $\begin{array}{l}\text { PV System Stand-by Losses } \\
\text { (kWh) }\end{array}$ & 377 & 318 & 347 & 260 & 287 & 320 & 344 & 399 & 406 & 457 & 470 & 377 & 4364 \\
\hline $\begin{array}{l}\text { \% PV System Stand-by Losses } \\
\text { of Total PV Production }\end{array}$ & 8.3 & 5.0 & 6.0 & 3.5 & 3.5 & 4.8 & 5.9 & 9.6 & 13.9 & 21.8 & 20.7 & 12.3 & 7.3 \\
\hline $\begin{array}{l}\text { PV Electricity Exported to Utility } \\
\text { (kWh) }\end{array}$ & 1167 & 3377 & 2899 & 5334 & 4235 & 2727 & 3374 & 2068 & 1275 & 700 & 753 & 970 & 28879 \\
\hline $\begin{array}{l}\% \text { of Total PV Production } \\
\text { Exported }\end{array}$ & 25.7 & 52.8 & 50.0 & 71.3 & 51.1 & 41.0 & 57.7 & 49.7 & 43.7 & 33.5 & 33.1 & 31.5 & 48.5 \\
\hline
\end{tabular}




\subsubsection{Monthly PV Performance}

The results of the measured PV performance are summarized in Table 6-2 for monthly and annual totals. For the months of June and July in 2001, the building produced more electricity than was consumed. The excess PV production not used in the building was considered exported to the utility. For these months, the percent of the building load that was met through PV production was greater than $100 \%$.

The average hourly measured PV production profile by month is graphed in Figure 6-13.

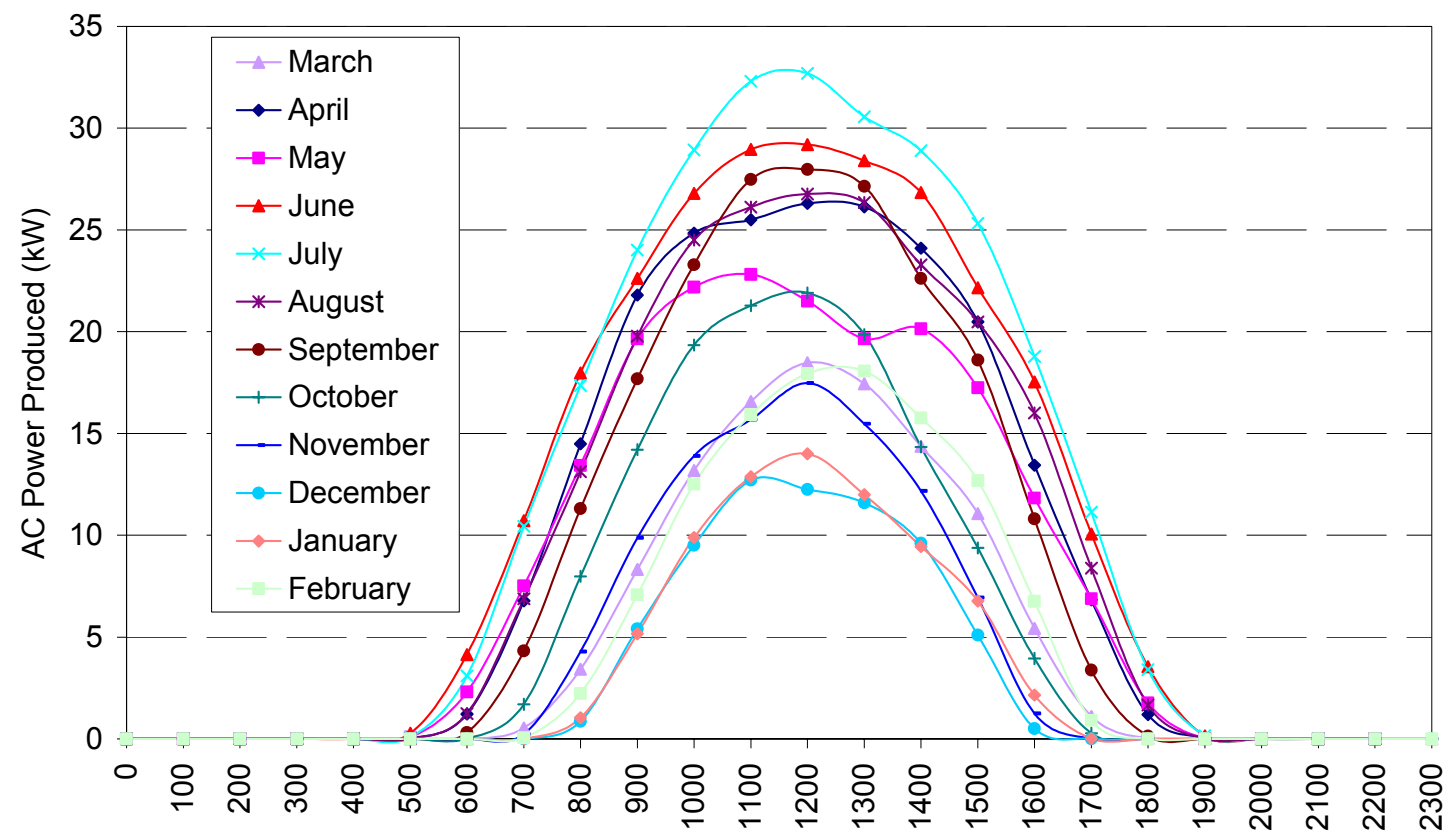

Hour of the Day

Figure 6-13 Average hourly power profile by month for PV production, March 1, 2001 through February 28, 2002

Figure 6-13 demonstrates that June and July had the highest hourly average power production. This load shape profile chart gives 24-hr PV production averages over each month. Eastern Standard Time is used for all time measurements in this graph.

The monthly comparison of PV production profiles demonstrates the drastic reduction in PV production from summer to winter months. The maximum hourly AC PV production, shown in Table 6-2, varies from $45.15 \mathrm{~kW}$ in March to $27.43 \mathrm{~kW}$ in December, primarily because of the average array tilt of $8^{\circ}$. The monthly energy production is reduced in the winter because of the tilt angle, the additional cloudy weather in the winter, and the short solar day. See Table 6-2 for the monthly production maximums. The peak hourly production occurred in March because of cool cell temperatures combined with high solar radiation in the plane of the array.

An optimized PV array tilt design would account for low winter altitude angles. By conducting multiple simulations at varying array tilt angles, NREL determined that the optimal tilt angle for a typical year in Cleveland would be $27^{\circ}$. At this optimal angle, as Figure 6-14 shows, the projected annual AC PV production would be $68,145 \mathrm{kWh}(245.3 \mathrm{GJ})$, or $4.2 \%$ greater than the simulated tilt angle of $8^{\circ}$. Because of the architectural issues associated with steeper panels, the reduction in production is probably acceptable. Figure 6-14 also demonstrates that an average tilt angle of $8^{\circ}$ was an adequate representation 
of the multiplane array, as this angle represents the average annual production over the range of PV string angles.

Also evident in Figure 6-13 is the nonsymmetrical power profile for the month of May. The remaining 11 months were reasonably symmetrical around the peak production at solar noon, although the average PV production during May afternoons was reduced in comparison to the morning hours. This results from high frequency of afternoon clouds and thunderstorms during May.

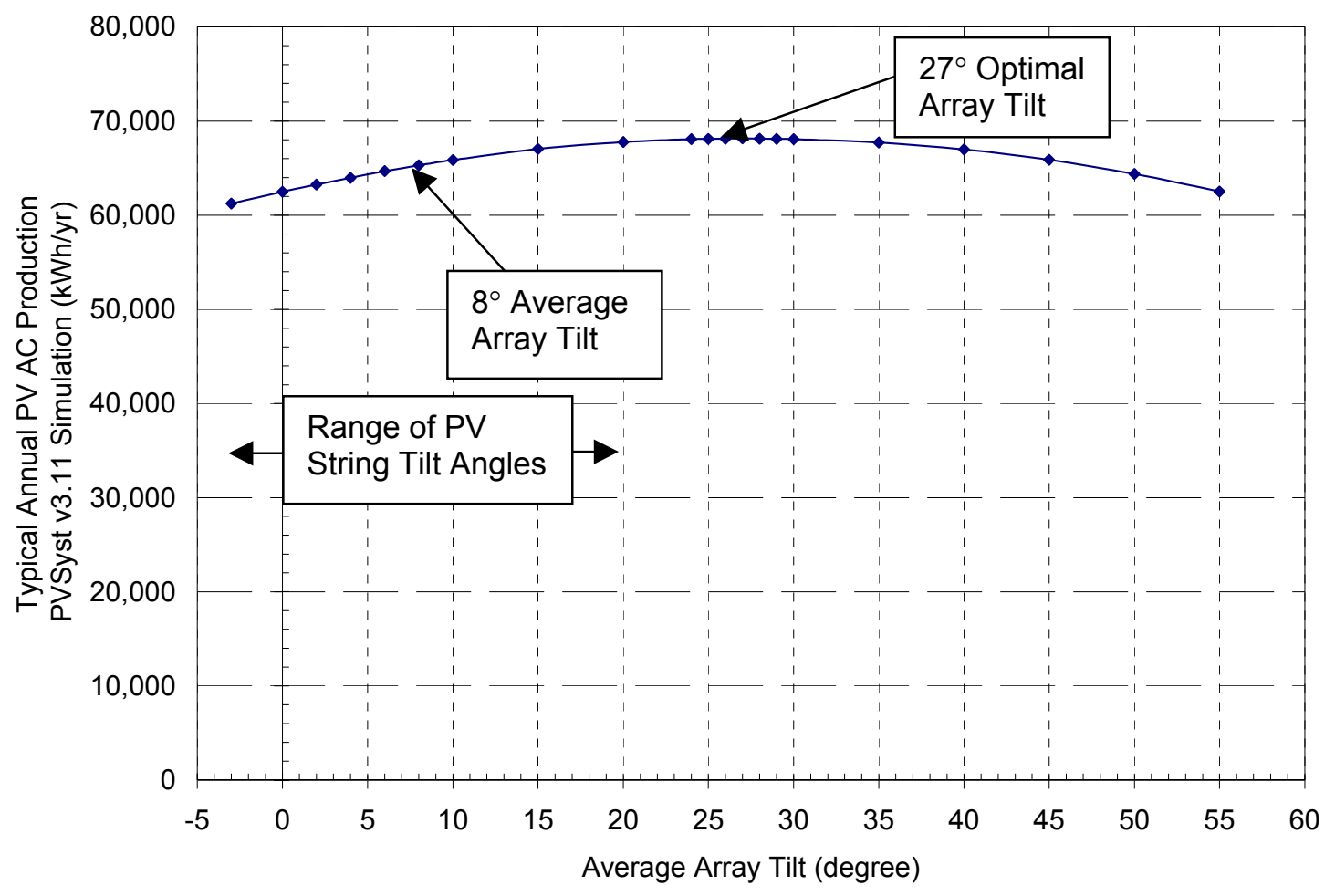

Figure 6-14 PV array tilt optimization

\subsubsection{Inverter-Transformer Efficiency}

To verify proper operation of the inverters and isolation transformers, the team investigated the efficiency of converting the DC PV electricity to utility quality three-phase AC electricity. The inverter and transformer efficiency is the product of the inverter efficiency and the transformer efficiency. To calculate the inverter-transformer efficiency, the measured PV AC power available to the building from all three subarrays was divided by the total available PV DC power. This was then compared to published efficiency curves for this inverter and isolation transformer (Xantrex 2003, Square-D 2003), and the comparison is shown in Figure 6-15. Above $15 \mathrm{~kW}$, the inverter-transformer efficiency was relatively constant at $94 \% \mathrm{DC}$-to-AC conversion efficiency. The measured inverter-transformer efficiency is verified in Figure 6-15, and no significant unpredicted losses caused by the inverter or transformer can be seen. This efficiency was also used as an input to the model in the annual system simulation. 


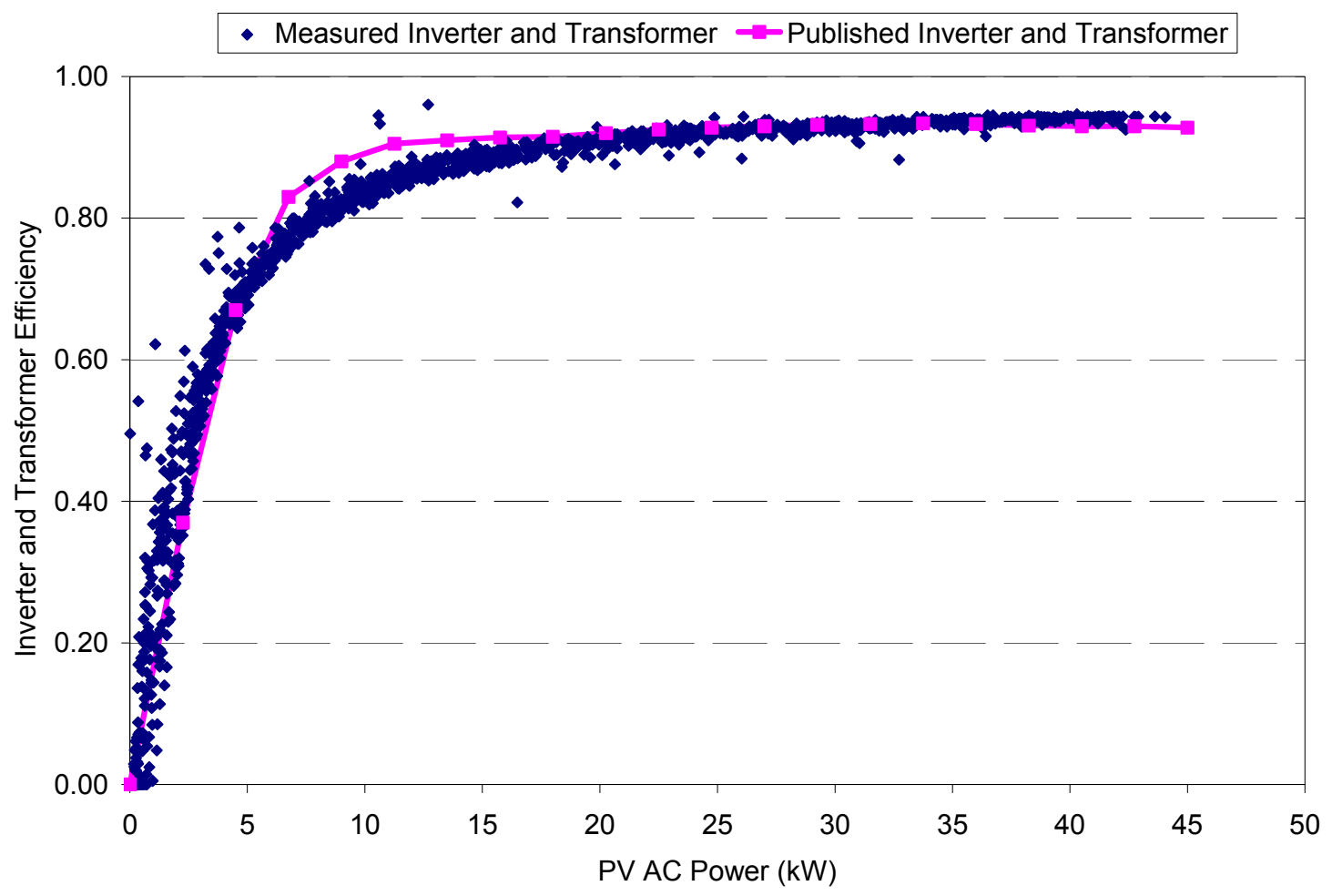

Figure 6-15 Measured versus published PV inverter-transformer efficiency, March 1, 2001 through February 28, 2002

\subsubsection{Solar Radiation Conversion Efficiency}

Another efficiency to consider in evaluating the PV performance was the effectiveness of harvesting the available solar resources for generating electricity. This overall AC electricity generation efficiency was determined by a combination of the inverter-transformer efficiency and the PV cell efficiency. To determine the total solar radiation incident on the PV array, the global horizontal radiation measured on site was used. Using measured global horizontal radiation, outdoor dry-bulb temperature, and relative humidity, direct normal beam radiation at each hour of measured data was calculated (Perez et al. 1990). With direct normal beam radiation calculated, the total radiation on the PV array was calculated at an average collector angle of $8^{\circ}$. The diffuse radiation component in the plane of the collector was calculated using an isotropic index method by Hay and Davies (Hay 1978). The solar radiation to AC electricity efficiency was calculated using the total calculated insolation on the $4671.5-\mathrm{ft}^{2}\left(434.0-\mathrm{m}^{2}\right) \mathrm{PV}$ array and the measured PV AC electricity production at a given hour. This electricity generation efficiency was calculated for each daytime hour of the year and graphed in Figure 6-16. 


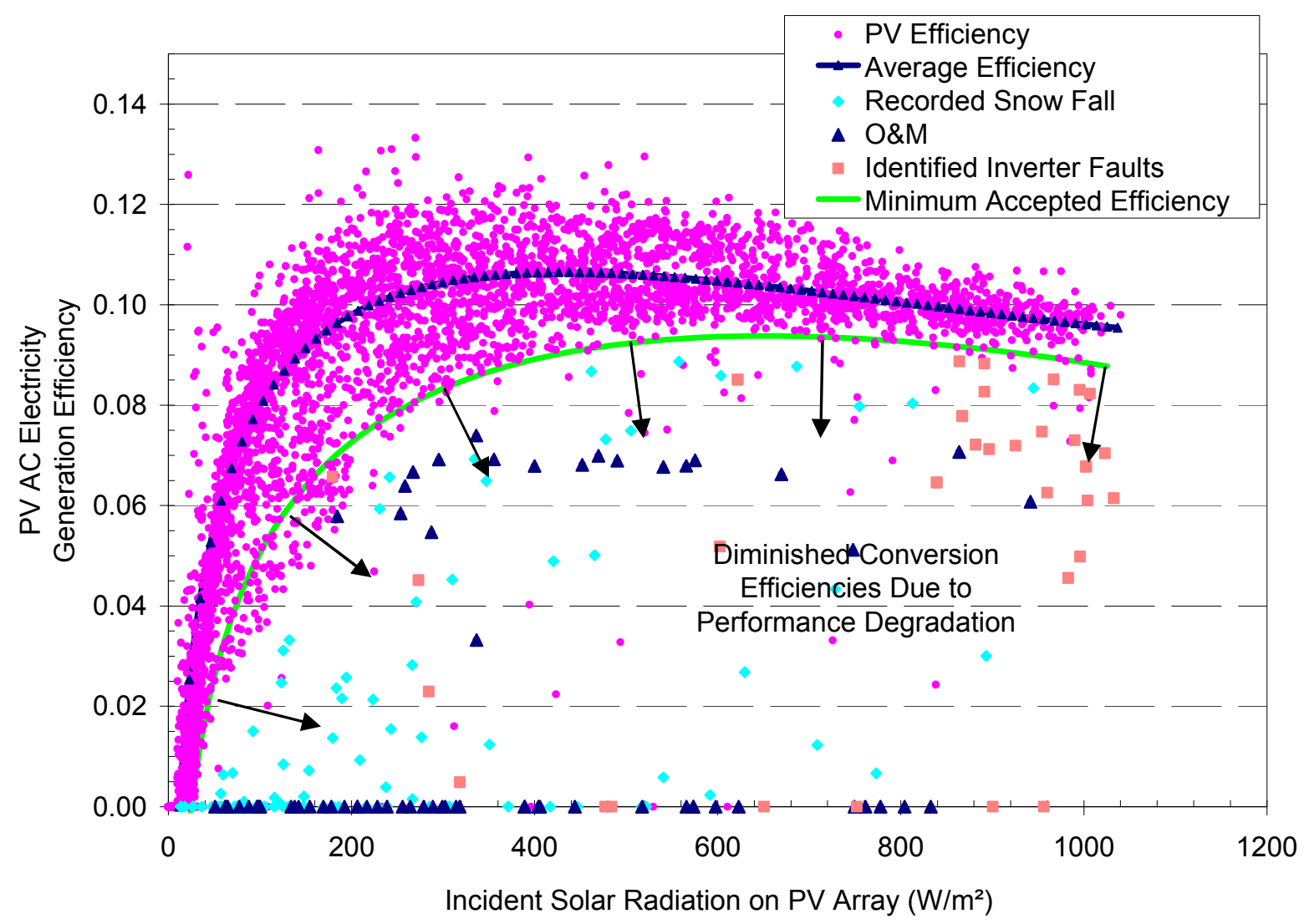

Figure 6-16 Measured, average, and minimum PV AC electricity generation efficiency, March 1, 2001 through February 28, 2002

Also graphed in Figure 6-16 is the calculated average conversion efficiency at bins of $10 \mathrm{~W} / \mathrm{m}^{2}$ $\left(0.2 \mathrm{~W} / \mathrm{ft}^{2}\right)$ of incident solar radiation. This average, which was based on expected electricity generation efficiencies, does not include clearly degraded efficiencies. Clearly degraded efficiencies are shown in Figure 6-16 as efficiencies below the minimum accepted efficiency line, but not including the grouping slightly below the minimum efficiency line at incident solar ranges between 4.6 and $18.6 \mathrm{~W} / \mathrm{ft}^{2}(50-200$ $\mathrm{W} / \mathrm{m}^{2}$ ). The effect of reduced inverter-transformer efficiency is evident for incident array radiation below $18.6 \mathrm{~W} / \mathrm{ft}^{2}\left(200 \mathrm{~W} / \mathrm{m}^{2}\right)$. For greater incident array radiation, the generation efficiency varied in the accepted range of $8 \%$ to $12 \%$. Considering the inverter, transformer, and the $\mathrm{PV}$ module rated efficiency at $92.9 \mathrm{~W} / \mathrm{ft}^{2}\left(1000 \mathrm{~W} / \mathrm{m}^{2}\right)$ and $77^{\circ} \mathrm{F}\left(25^{\circ} \mathrm{C}\right)$, the rated $\mathrm{AC}$ generation efficiency was $12 \%$ (Xantrex 2003 , Square-D 2003, BP 2003). The measured AC generation efficiency in Figure 6-16 is typically less then the rated generation efficiency because the measured cell temperatures at $92.9 \mathrm{~W} / \mathrm{ft}^{2}\left(1000 \mathrm{~W} / \mathrm{m}^{2}\right)$ are usually greater than $77^{\circ} \mathrm{F}\left(25^{\circ} \mathrm{C}\right)$. As shown below, high cell temperatures result in lower module efficiencies.

To determine if the generation efficiency that represents normal operating conditions or if the performance was degraded, a minimum expected operating efficiency (shown in Figure 6-16) was established. For each incident radiation bin, the average efficiency minus 2 times the standard deviation was calculated and plotted in Figure 6-16 as the minimum accepted generation efficiency. For measured efficiencies above this line, the electricity generation for the available solar radiation was considered typical operation. For measured conversion efficiencies below this minimum accepted efficiency line, NREL considered electricity generation degraded. Clearly degraded efficiencies were not included in this standard deviation bin calculation. Clearly degraded efficiencies are shown in Figure 6-16 as efficiencies below the minimum accepted efficiency line, but not including the grouping slightly below the minimum 
efficiency line at incident solar ranges between 4.6 and $18.6 \mathrm{~W} / \mathrm{ft}^{2}\left(50-200 \mathrm{~W} / \mathrm{m}^{2}\right)$. This PV performance degradation procedure identified periods of suboptimal electricity generation, and the team then investigated potential causes for this reduction in conversion efficiency.

The PV performance was considered degraded for $5 \%$ of the total operational hours over the second year evaluation period. When hours of degraded generation efficiency were identified, the need to quantify generation losses arose. The effects of incident solar radiation and PV cell temperature on typical performance were considered to determine what the typical performance should be for suboptimal conditions. For hours of normal PV system operation, the DC subarray current was plotted versus incident solar radiation in Figure 6-17.

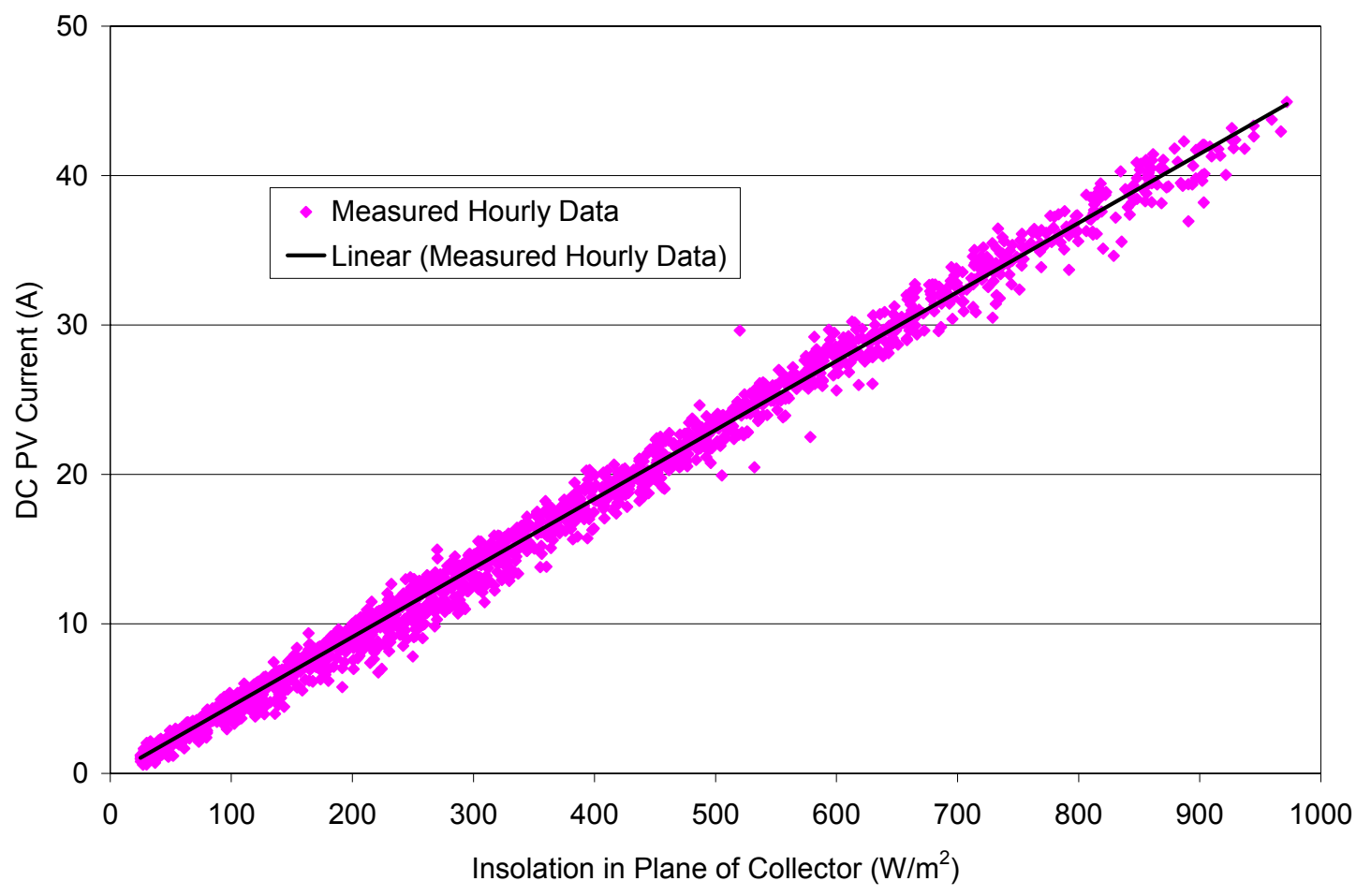

Figure 6-17 DC subarray A current as a function of incident solar radiation, March 1, 2001 through February 28, 2002

The linear relationship between measured incident solar radiation $\left(I_{C}\right)$ and typical DC operating current was defined as:

DC PV Current $=0.0462 \cdot I_{C}-0.1278$

Similarly, the dependence of DC operating voltage on cell temperature is plotted in Figure 6-18. 


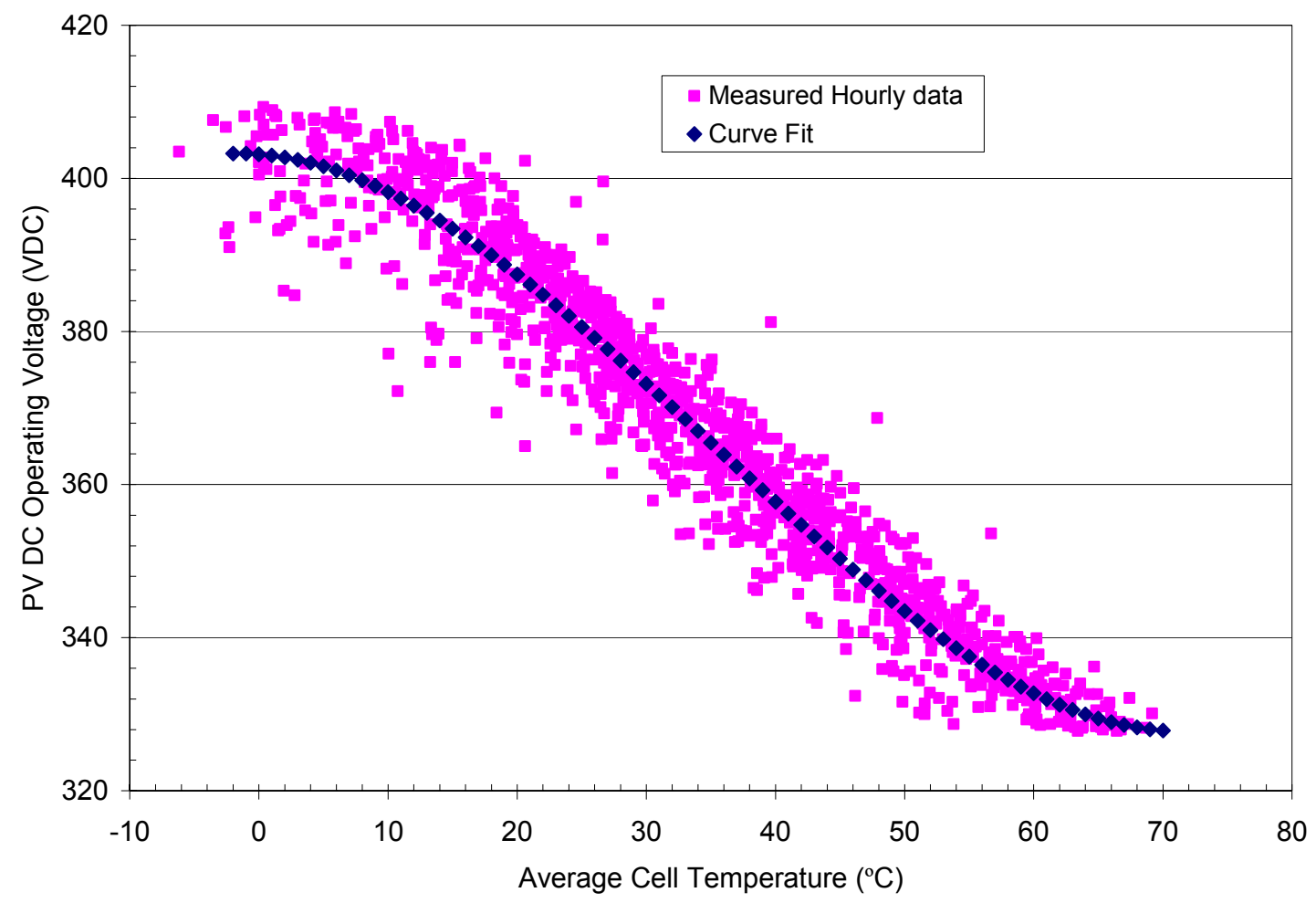

Figure 6-18 DC subarray A voltage as a function of cell temperature, March 1, 2001 through February 28, 2002

A regression analysis provides a third-order polynomial curve fit as follows:

$$
V D C=0.00039 \cdot T_{C}^{3}-0.0409 \cdot T_{C}^{2}-0.123 \cdot T_{C}+403.6
$$

where:

$V D C=\mathrm{DC}$ operating voltage of $\mathrm{PV}$ subarray

$T_{C}=$ Average PV cell temperature $\left({ }^{\circ} \mathrm{C}\right)$.

Equations 6-3 and 6-4, combined with the measured inverter-transformer efficiency, were used for periods of performance degradation to calculate the expected AC PV power production based on measured environmental variables, resulting in the quantification of performance degradation.

\subsubsection{PV Performance Degradation}

For periods of performance degradation, several reasons were identified. This included snow accumulating on the PV array, unscheduled operation and maintenance issues, and inverter-transformer faults. Figure 6-16 aids in identifying PV performance degradation causes from March 2001 through February 2002.

One possible exception in the determination of diminished generation efficiencies occurs between 4.6 and $18.6 \mathrm{~W} / \mathrm{ft}^{2}\left(50-200 \mathrm{~W} / \mathrm{m}^{2}\right)$ in Figure 6-16. At this insolation range, there is a grouping of 100 hours where the generation efficiency is slightly below the minimum efficiency curve. The predicted cause for this high density of slightly diminished generation efficiency hours was attributed to the differences between beam and diffuse incident solar radiation at this range of insolation. If the insolation were mostly beam radiation, which would occur during clear mornings and evenings at this insolation range, the incidence angles (angle between array normal and sun) would be in the range from $60^{\circ}$ to $90^{\circ}$. For 
incidence angles in this range, it is understood that $10 \%$ to $80 \%$ of the beam radiation can be reflected off the array (King et al. 1998). This condition resulted in the diminished conversion efficiencies present in this range of insolation. For a primarily diffuse sky in this insolation range, no incidence angle dependence was seen. Therefore, conversion efficiencies were not diminished because of reflected solar radiation during diffuse sky conditions. This is an issue with the diffuse sky radiation model.

Figure 6-16 identifies hours during which measurable snowfall was present at Hopkins Airport in Cleveland. During times of reduced AC conversion efficiency, the losses resulting from snow-related PV production degradation were calculated using the expected performance equations as discussed in Section 6.3.2.3. It is estimated that snow reduced the overall annual PV production by $769.0 \mathrm{kWh} / \mathrm{yr}$ $(2,768 \mathrm{MJ} / \mathrm{yr})$, or by $1.2 \%$ of the total annual PV production. Figure 6-19 is a photograph of accumulated snow on the flat sections of the PV array.

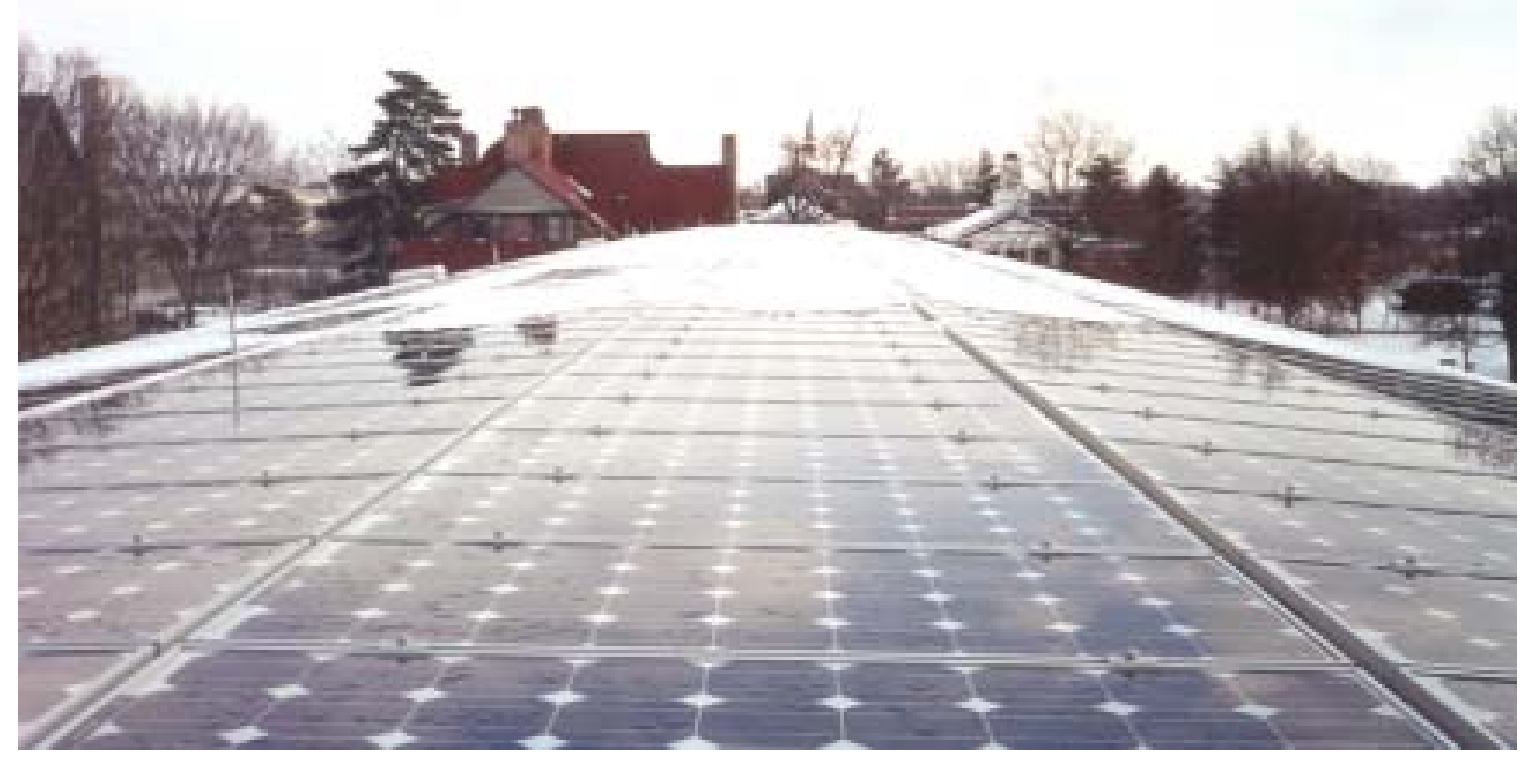

Figure 6-19 PV array partially covered with snow

During short periods within the 12 months that PV system performance data were collected and analyzed, one or more of the inverters was turned off to allow for safe installation of data collection instrumentation. Whenever possible, data collection equipment was installed at night so that PV performance would not be affected. But during times when measurements such as current-voltage curve trace measurements and meter verification were required, it was necessary to shut down one or more inverters during the day. These shutdowns led to PV production degradation resulting from operational and maintenance downtime. Improper operation (inverters accidentally turned off over the weekend, for example) also contributed to this degradation. Using the expected performance equations, the evaluators calculated that $879.4 \mathrm{kWh} / \mathrm{yr}(3,166 \mathrm{MJ} / \mathrm{yr})$, or $1.5 \%$ of the annual PV production, was lost because of PV system downtime related to operations and maintenance.

A separate performance degradation issue arose because of the inverters shutting down near peak operating limits, as illustrated in Figure 6-20. Occasionally, when the inverters were operating at the maximum power output of $15 \mathrm{~kW} \mathrm{AC}$, they automatically tripped off, and then restarted after 5 minutes. To identify this inverter fault, minute data collected on PV system performance were considered. Because the automatic restart after an inverter fault of this type was 5 minutes, an identifiable pattern in PV production displayed by the minute was evident. Figure 6-20 shows a day when this occurred multiple times with all three inverters. Note that displaying the AC PV production in hourly averages does not identify this inverter fault pattern. In an attempt to fix this problem, the inverter set point of 
"VAC_Max" was increased, as the error code from the inverter indicated a high AC line voltage fault. This set point controls the maximum allowable utility voltage. This specific inverter problem was not completely resolved until after March 2003. Therefore, the measured PV production during this evaluation included the inverter voltage fault degradation.

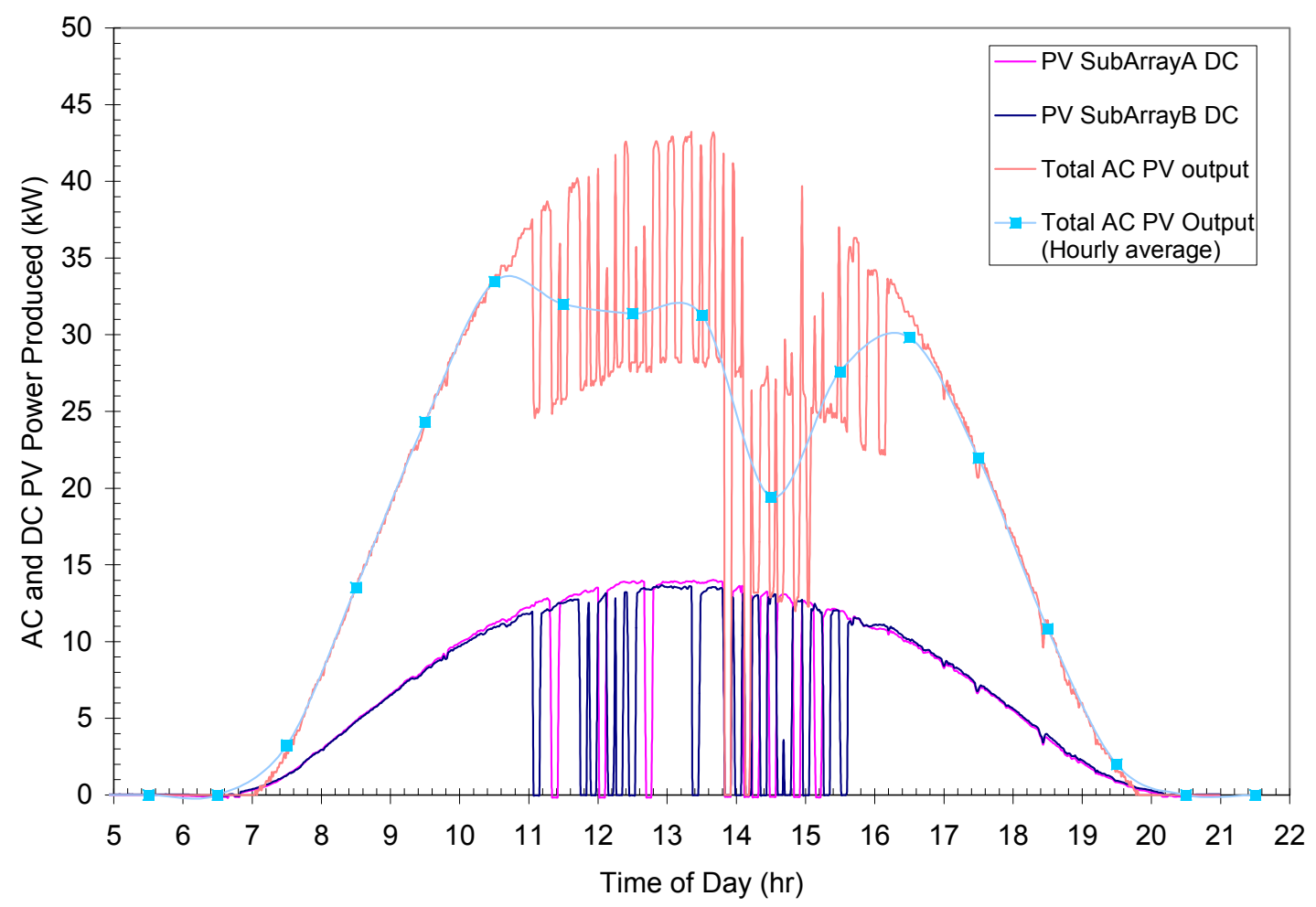

Figure 6-20 Inverter shutdown example with minute and hourly PV performance, April 28, 2001

Other system component faults included occasional AC PV circuit breaker trips and additional unidentified inverter faults. The unidentified inverter faults included all the degraded generation efficiency hours that did not have a documented efficiency degradation cause. A single case of circuit breaker faults was documented. It is expected that the cause for the breaker faults involved a high inrush current required to energize the isolation transformers during a loss of grid power to the PV system. Inverter faults with unidentified causes are shown in Figure 6-16 as hours below the minimum conversion efficiency line that have not been attributed to any of the previously described degradation issues. The investigators calculated that $707.9 \mathrm{kWh} / \mathrm{yr}(2,548 \mathrm{MJ} / \mathrm{yr})$, or $1.2 \%$ of the annual PV production, was lost because of PV system downtime related to system component faults. It must be noted that this time was minimized because continuous monitoring detected trips and inverters were quickly reset. Without monitoring, these downtimes may have been much longer.

The PV performance summary in Table 6-2 contains information on additional issues related to PV performance degradation. During nighttime hours when the PV system was in standby mode, the inverters and transformers consumed electricity. This standby parasitic load of the three inverters and isolation transformers was a constant $900-1000 \mathrm{~W}$ during times of no PV production. This loss was attributed to the general-purpose isolation transformers. The primary purpose of the isolation transformers was to transform the three-phase AC 208-delta output of the inverters to utility-compatible three-phase AC 208-wye/120. The no-load transformer inefficiency of $2 \%$ resulted in a standby loss of $4,363.5 \mathrm{kWh} / \mathrm{yr}(15,708 \mathrm{MJ} / \mathrm{yr})$, or $7.3 \%$ of the total PV production. This does not include transformer 
losses when the PV system is generating power. Figure 6-21 shows the electricity consumption, or negative PV supply, during periods of no PV production.

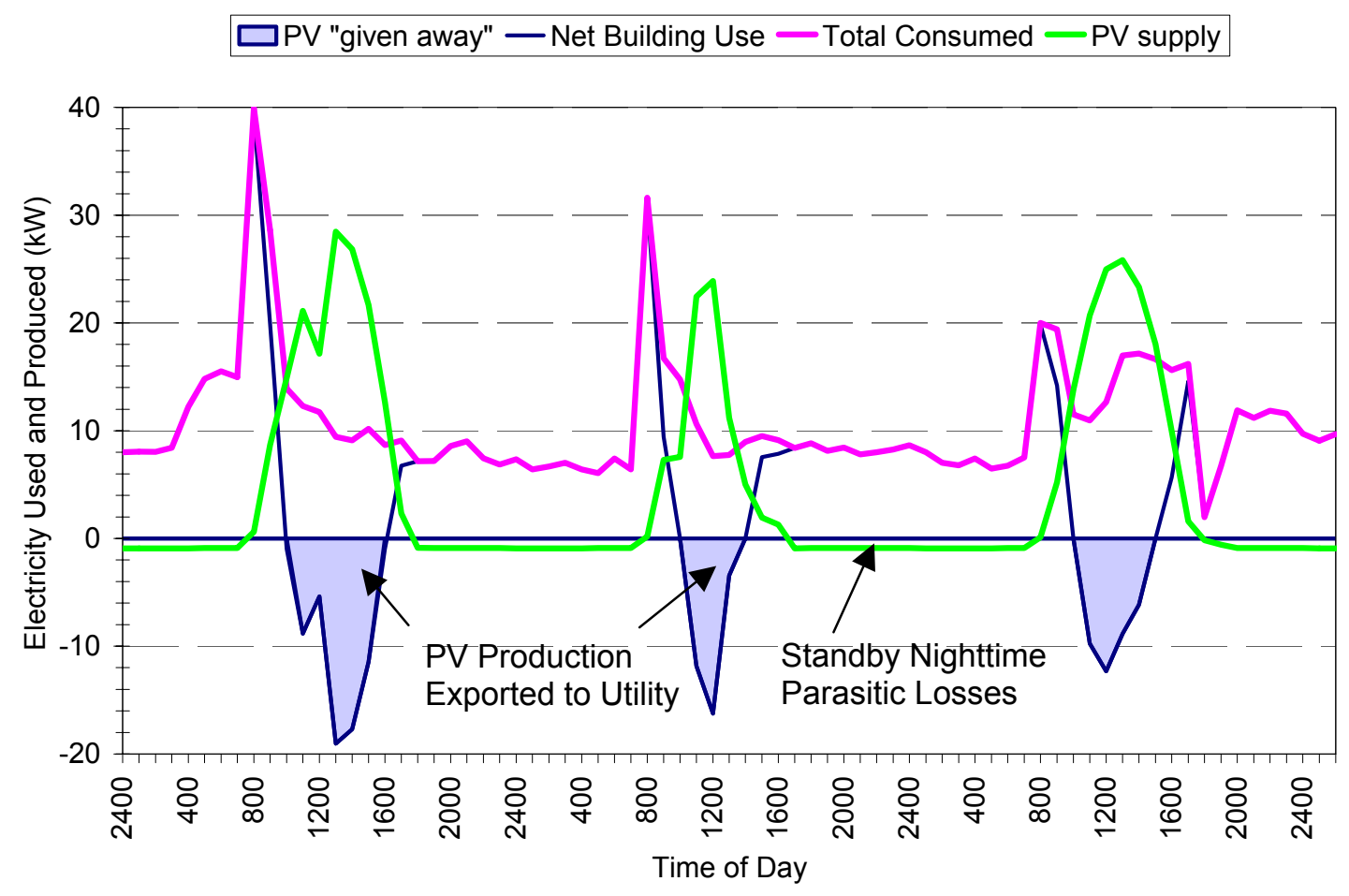

Figure 6-21 Net building use and nighttime PV system consumption example, November 13 through November 15, 2001

Figure 6-21 also illustrates the issue of net metering with Oberlin's Municipal Light and Power utility company. When the PV system produced more electricity than was being used on site, the excess energy was exported to the utility grid. Although arrangements for a net-metering agreement were in progress during the second year of occupancy, the Lewis Center did not get credit for electricity it sent back to the utility grid from March 2001 through February 2002. The utility meters, which only measured electricity flow in one direction, did not allow for an accounting of energy supplied back to the utility grid. During this time, the Lewis Center PV system exported to the grid $28,879 \mathrm{kWh}(103,964 \mathrm{MJ})$, or $48 \%$ of the total PV produced. Of the total PV energy produced over this year, 30,614 kWh $(110,211 \mathrm{MJ})$, or $52 \%$ was used in the Lewis Center. The second year utility bills would have been reduced by $\$ 1,415$ with a net metering agreement and an energy and distribution rate of $\$ 0.049 / \mathrm{kWh}$. Without financial credit from the utility for excess electricity produced by the system, the financial payback period is greatly extended. Bi-directional utility meters were installed as part of a net metering agreement in April of 2002, as discussed in Section 5.2.4.

A summary of the performance degradation losses is provided in Table 8-3 in Section 8.3.

\subsubsection{Typical PV Production}

In Cleveland, the amount of total global horizontal radiation is $1,383 \mathrm{kWh} / \mathrm{m}^{2}\left(4,979 \mathrm{MJ} / \mathrm{m}^{2}\right)$. During the measurement period from March 1, 2001, to February 28, 2002, 1,358 kWh $/ \mathrm{m}^{2}\left(4,889 \mathrm{MJ} / \mathrm{m}^{2}\right)$ of global radiation was available, which was $1.8 \%$ less solar radiation than is typically available annually in Cleveland. To determine the effect of reduced solar radiation on the simulated performance, Cleveland TMY2 weather data were used to generate a model that would adequately represent the typical PV 
performance without preventable degradations. The degradations due to snow are not preventable and are included in the typical PV production. Isolation transformer losses during typical operation are included in the typical PV production as inverter inefficiencies. Nighttime stand-by consumption of these transformers does not reduce or degrade PV production, and therefore, is not included in any of the annual PV production values. The annual PV production for a typical weather year was simulated at $64,500 \mathrm{kWh} / \mathrm{yr}(232.2 \mathrm{GJ} / \mathrm{yr})$. The typical production is used for calculating typical site and source building performance. Table 6-3 provides a summary of the annual performance of the measured PV production including degradations, the measured performance not including degradations, the simulated performance with measured weather data not including degradations, and the typical performance simulated with TMY2 data. The simulated performance with measured weather and without degradations is within $4 \%$ of the measured performance without considering degradations.

Table 6-3 Annual PV Performance Summary

\begin{tabular}{|l|c|}
\hline \multicolumn{1}{|c|}{ Measured and Simulated PV Production } & $\begin{array}{c}\text { Annual Production } \\
\text { (kWh/yr) }\end{array}$ \\
\hline $\begin{array}{l}\text { March 01, 2001 through February 28, 2002 measured } \\
\text { (with degradations) }\end{array}$ & $59,518 \mathrm{kWh}$ \\
\hline $\begin{array}{l}\text { March 01, 2001 through February 28, 2002 measured } \\
\text { (without degradations) }\end{array}$ & $61,874 \mathrm{kWh}$ \\
\hline $\begin{array}{l}\text { Simulated with measured 2001-2002 weather } \\
\text { (without degradations) }\end{array}$ & $63,915 \mathrm{kWh}$ \\
\hline Simulated Cleveland TMY2 & $64,500 \mathrm{kWh}$ \\
\hline
\end{tabular}

\subsubsection{Maximum Power Point Tracking}

Each of the three inverters was designed to track the maximum power point as it changes with PV cell temperature and incident radiation, as shown in Figure 6-22 (BP 2003). This function allows the inverter to seek the optimal DC operating voltage that results in maximum PV power production at the present operating conditions. To verify that this function was operating, NREL considered DC operating voltage as a function of cell temperature. 


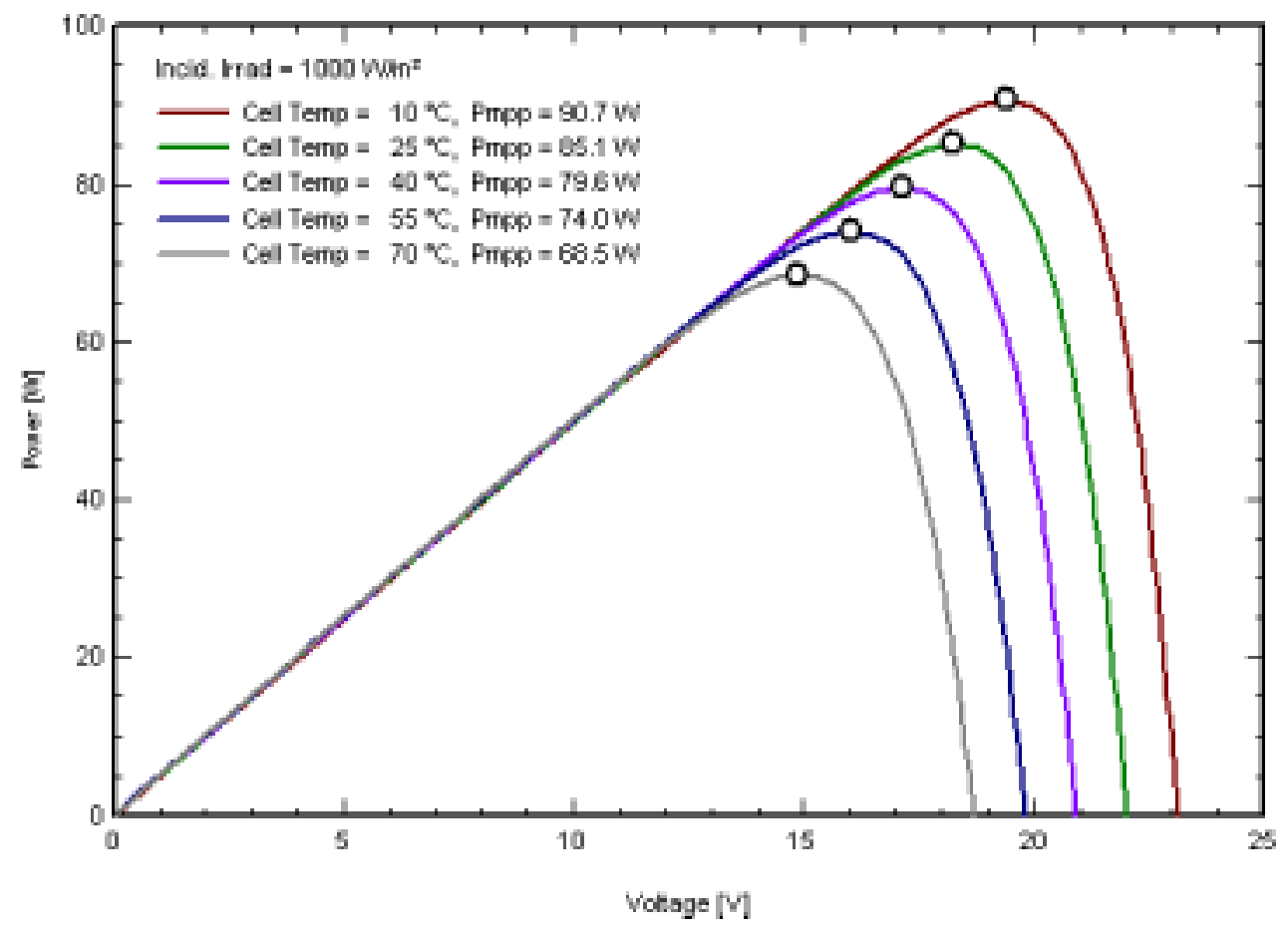

Figure 6-22 PV single-panel published power-voltage curves at varying cell temperatures

Figure 6-18 shows the PV DC operating voltage as a function of cell temperature. The DC PV voltage decreases from $410 \mathrm{VDC}$ at cooler cell temperatures to $328 \mathrm{VDC}$ at the warmest cell temperatures. This indicates that the maximum power point tracking (MPPT) function was operating.

To further investigate the success of the MPPT function, current-voltage (I-V) curve trace measurements were performed on June 19 and 20, 2001. At varying insolation ranges and cell temperatures, I-V curve traces were collected for all three subarrays. A sample of a measured I-V curve (and corresponding power-voltage curve) for subarray A is given in Figure 6-23. This curve trace was taken at an incident solar radiation level of $89.3 \mathrm{~W} / \mathrm{ft}^{2}\left(961 \mathrm{~W} / \mathrm{m}^{2}\right)$ and an average cell temperature of $135^{\circ} \mathrm{F}\left(57^{\circ} \mathrm{C}\right)$. 


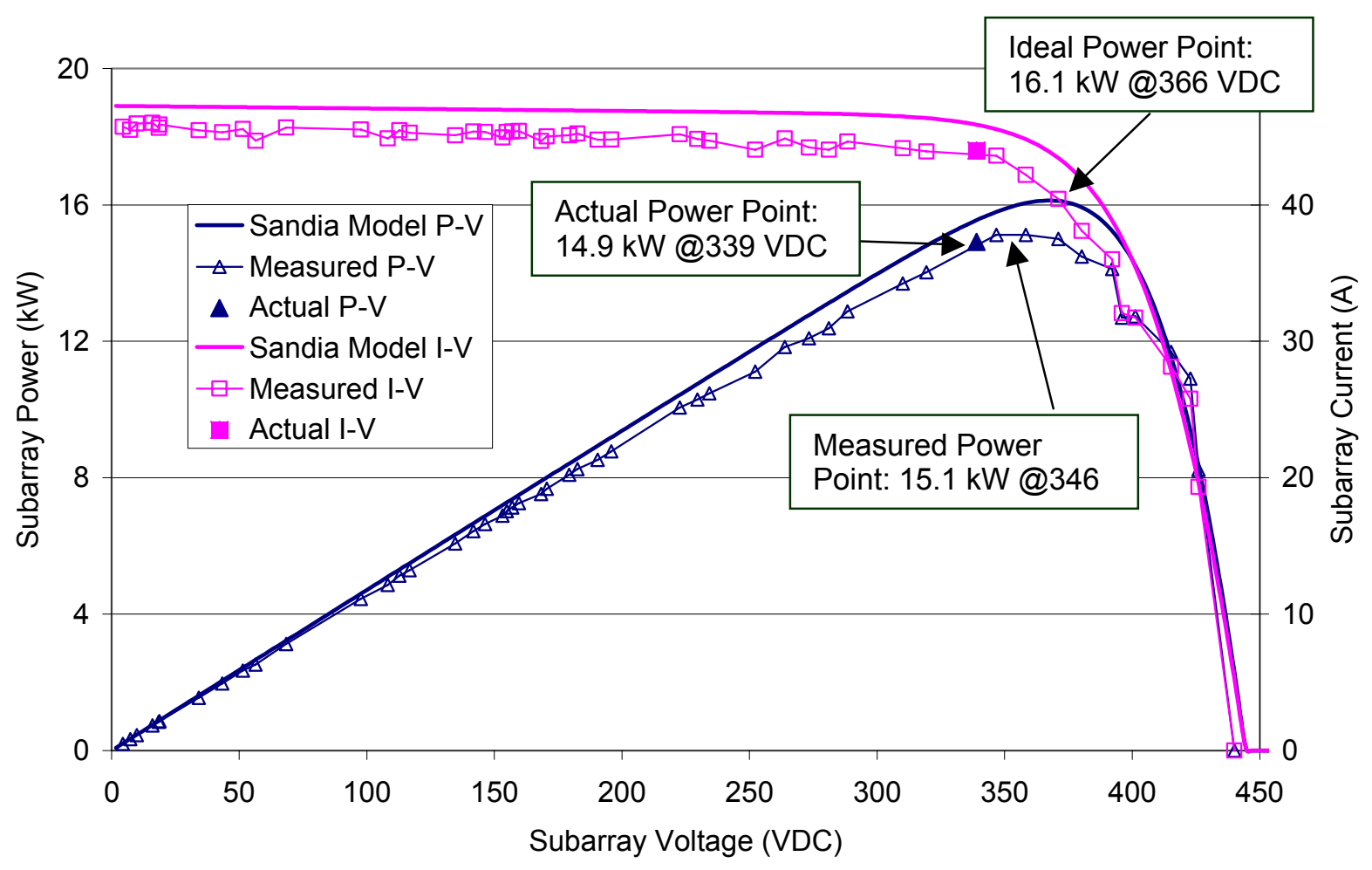

Figure 6-23 Subarray A power-voltage/current-voltage curve trace comparison

At these operating conditions, the I-V curve trace supplied a point on the I-V curve where the DC power was maximized. This point was the maximum power point of the array that each inverter was attempting to track. The measured power point was $15.1 \mathrm{~kW}$ at $346 V D C$ for subarray A. At similar environmental conditions, under normal operation, the actual power point the inverter chose was $14.9 \mathrm{~kW}$ DC at $339 V D C$, as shown in Figure 6-23. For this subarray, at these particular operating conditions, the actual maximum power point was within $200 \mathrm{~W}$ of the measured maximum power point. With the inverter tracking the maximum power point to within $98 \%$ of the measured maximum point, the MPPT was considered to be functioning at a high level of success. Similar results were seen for the other two subarrays at a range of summer operating conditions.

Also graphed in Figure 6-23 are the results from the Sandia Photovoltaic Performance I-V Curve Tracer Model. This model predicted the I-V curve trace for a wide range of operating conditions based on published PV panel performance at standard test conditions. When the single-panel standard test condition performance was extrapolated to $89.3 \mathrm{~W} / \mathrm{ft}^{2}\left(961 \mathrm{~W} / \mathrm{m}^{2}\right)$, with a cell temperature of $135^{\circ} \mathrm{F}$ $\left(57^{\circ} \mathrm{C}\right)$, and applied to an array of 10 parallel strings with each string consisting of 23 panels in series, an ideal I-V and P-V curve trace was generated and plotted in Figure 6-23. This ideal P-V curve trace supplies a maximum power of $16.1 \mathrm{~kW} \mathrm{DC}$ at $366 \mathrm{VDC}$ at the given operating conditions. This maximum power point was $7 \%$ higher than the measured power point at the same operating conditions. The discrepancy can typically result from wiring and connection resistance, diode losses, and panel parameter mismatches. These expected losses were used as inputs to the PVSyst simulation model, allowing the installed system and corresponding wiring losses to be modeled properly.

\subsection{Lighting and Daylighting Evaluation}

Lighting energy consumption is the largest single end use in commercial buildings, at $25 \%$ of the total energy used in all commercial buildings (DOE 2003). Thus, it is important to understand the performance 
of the lighting systems at the Lewis Center. Documenting and evaluating the methods for minimizing lighting consumption, such as daylighting design and occupancy sensors, are important segments of the full building analysis. The goals of the daylighting evaluation were to:

- determine the amount of electrical lighting offset by lighting design, daylighting, and occupancy controls as compared to the Base case,

- analyze the operation of the lighting and daylighting controls and optimize their performance,

- quantitatively and qualitatively assess the daylighting design, and

- document successes and weaknesses of the daylighting and lighting systems to expand the knowledge base in this area.

\subsubsection{Lighting and Daylighting Evaluation Methods}

The measurement segment of the daylighting analysis of the Lewis Center was performed based on a monitoring protocol developed by International Energy Agency Solar Heating and Cooling Programme (IEA/SHC) Task 21 Daylight in Buildings: Design Tools and Performance Analysis (Atif 1997). IEA/SHC Task 21 offers guidelines for measuring daylighting performance, predicting performance, and evaluating control parameters. The performance measurement section of this protocol outlines recommended techniques for monitoring the daylighting contribution to indoor illuminance and the corresponding electrical lighting reduction. These techniques include measurement of horizontal illuminance in selected daylit zones during varying sky conditions for typical summer, winter, and fall/spring seasons. Recommended illuminance levels for each lighting zone were verified in accordance with the Lighting Handbook of the Illuminating Engineering Society of North America (IESNA 2000). The Lighting Handbook requires simultaneous monitoring of external horizontal illuminance and electrical lighting consumption to complete the daylighting measurements.

In accordance with daylighting monitoring protocols, NREL continuously measured the illuminance at varying sky conditions for different seasons. These measurements were performed in the second-floor classroom, corridor, and a north side office. The locations of the illuminance measurements are shown in Figure 6-24. The illuminance was measured for nine points on the horizontal classroom work surfaces at a desk height of 30 in. $(76 \mathrm{~cm})$ (locations 1-9) and two vertical points on the white board (locations 10 and 11). Two points in the corridor (12 and 13) at a height of $3 \mathrm{ft}(0.9 \mathrm{~m})$ and two points in the north office (locations 14 and 15) at desk level were also measured. Each location was sampled every 5 seconds with calibrated photometers and recorded as 5-min averages. Finally, the outdoor illuminance (location 16) was measured.

These illuminance measurements were taken near the spring equinox (March 26-30, 2001), the summer solstice (June 18-21, 2001), and the winter solstice (January 3-4, 2002). The electric lights were manually turned off in the classroom and north office for each round of illuminance measurements. The corridor lights were on for the spring equinox measurements, but because of control changes, were off for the summer and winter solstice measurements. The blinds were all fully open for the illuminance measurements, except when shading effects and glare reduction were being examined. 


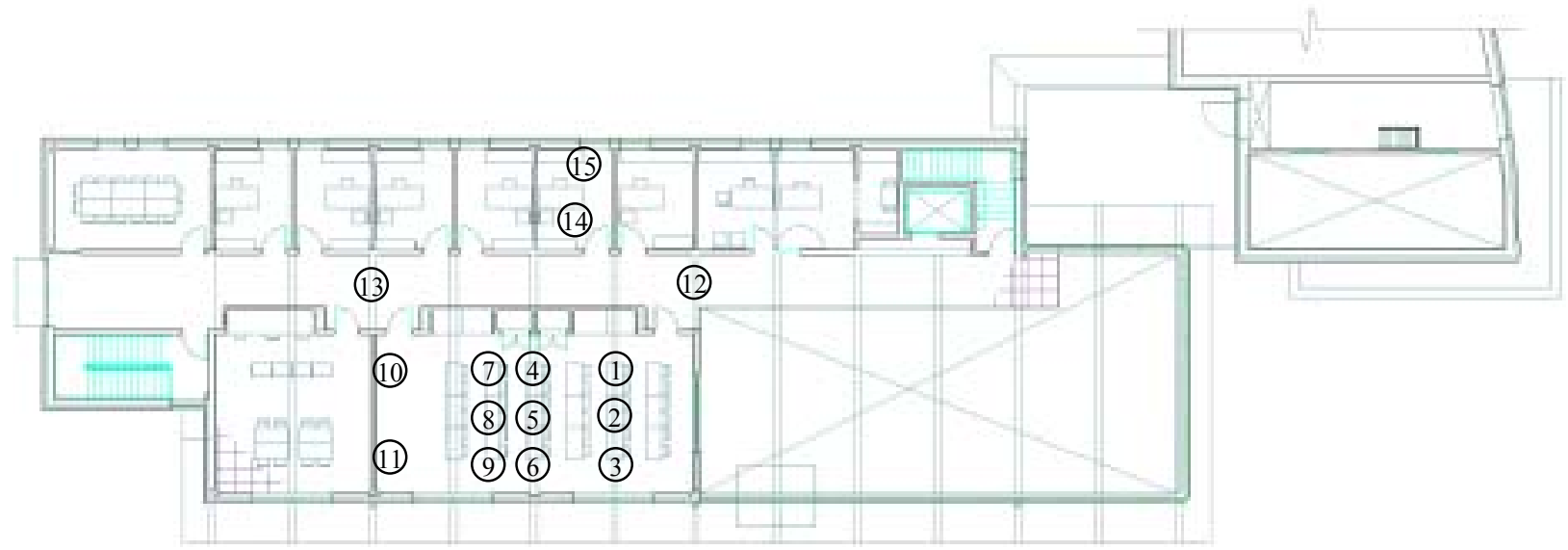

(16)

Figure 6-24 Second-floor continuous illuminance measurement locations (numbered circles)

In addition to the continuous measurements, handheld measurements were made in the first- and secondfloor classrooms and in the second-floor corridor. Figure 6-25 and Figure 6-26 show the locations of the handheld measurements. These measurements were made with Li-Cor LI-250 Light Meter. The primary purpose for handheld illuminance measurements was to determine illuminance levels in lighting zones not considered by the continuous measurement system.

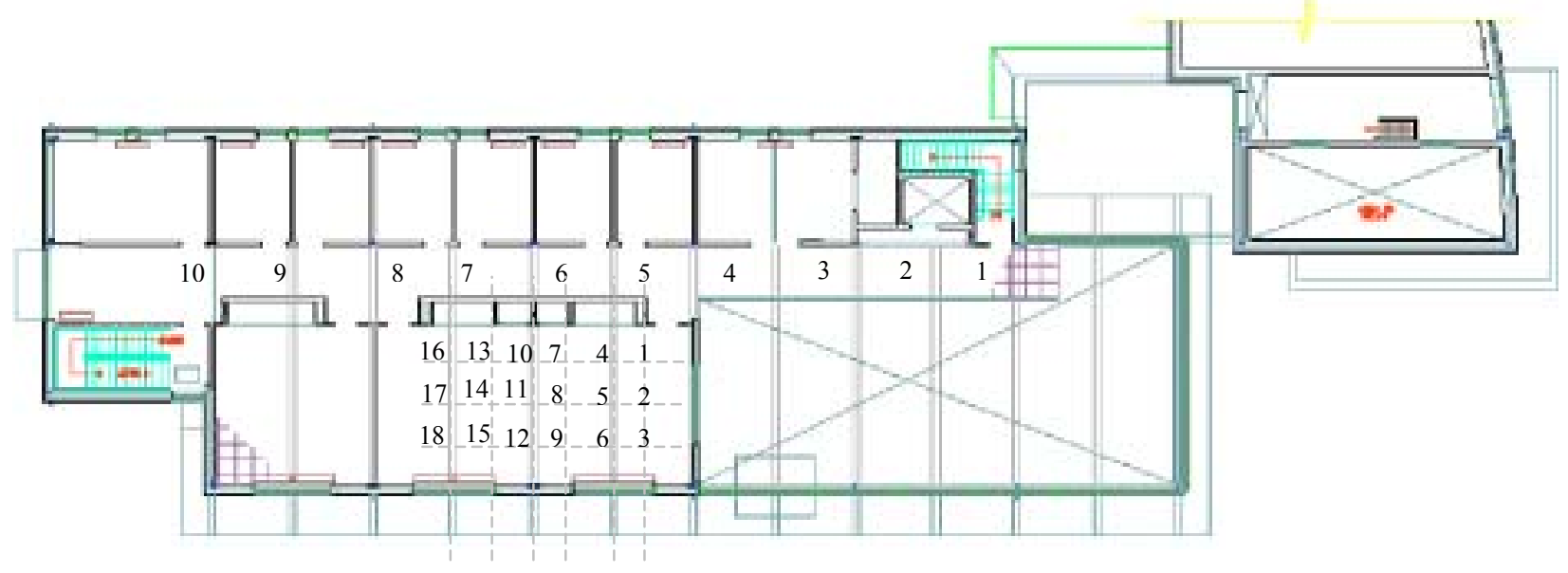

Figure 6-25 Second-floor corridor and classroom handheld illuminance measurement locations 


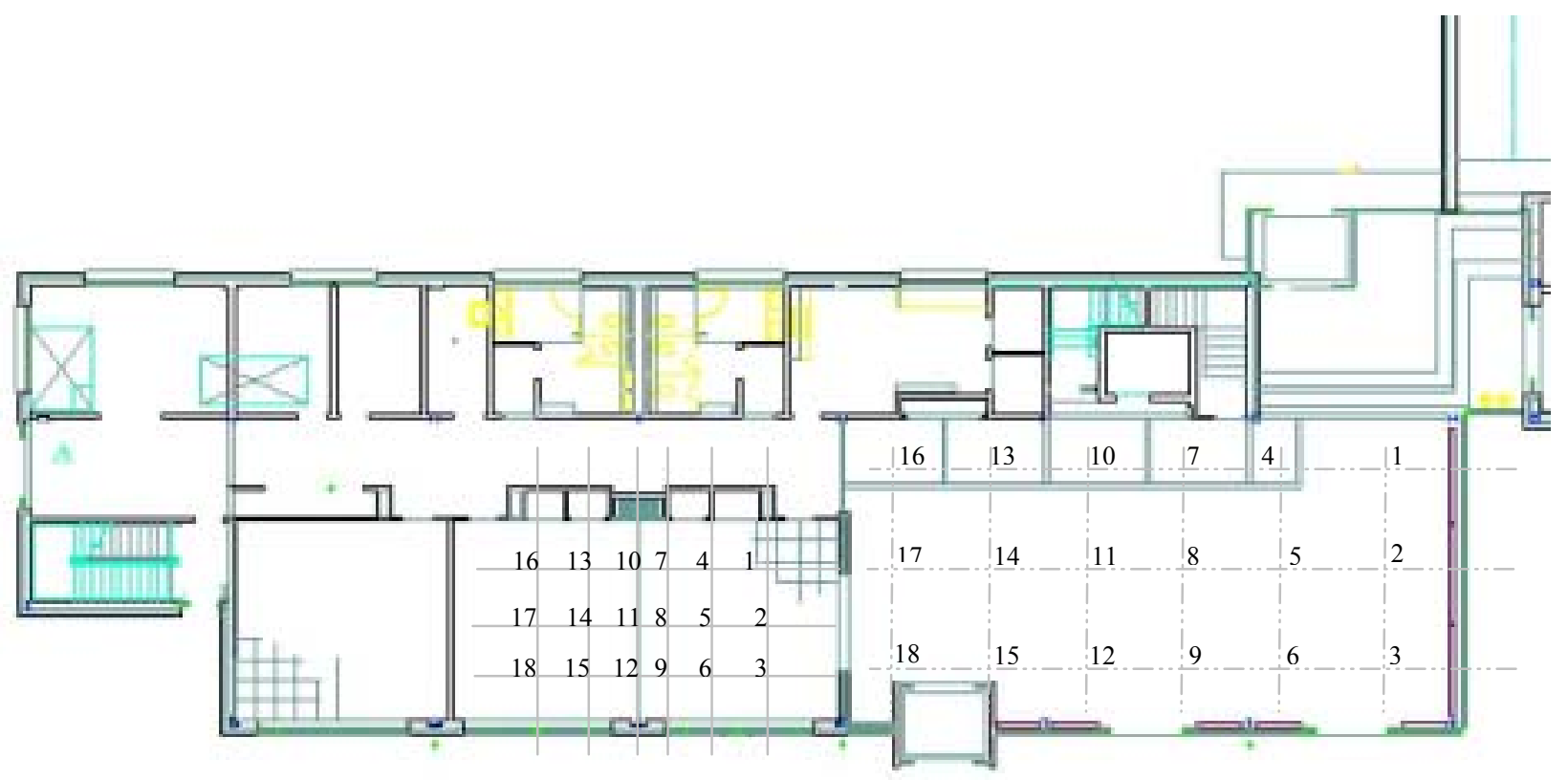

Figure 6-26 First-floor atrium and classroom handheld illuminance measurement locations

The handheld classroom measurements were made at desk level, $30 \mathrm{in} .(76 \mathrm{~cm})$ above the floor; the handheld corridor and atrium measurements were taken at a height of $48 \mathrm{in} .(122 \mathrm{~cm})$ above floor level. The measurements were taken for varying sky conditions and times of day.

The DAS measured lighting electric use from March 1, 2001 through February 28, 2003. Measured lighting energy consumption includes all area lighting electricity used in the building and in the adjacent parking lot and sidewalks. Auditorium lights, emergency lights, sidewalk lights, parking lot lights, and all indoor area lighting (excluding auditorium) were measured separately. Table 4-4 summarizes controls, fixtures, and end use measurement categories. The indoor area lighting category does not include any task lighting.

\subsubsection{Lighting and Daylighting Evaluation Results}

The lighting and daylighting evaluation was performed to yield an annual assessment of the quality and quantity of the lighting and daylighting at the Lewis Center, allowing daylighting performance to be assessed and potential retrofit opportunities to be identified. The lighting and daylighting evaluation contains an analysis of the metered energy consumption of the installed lighting; calculations of the electrical lighting displacement resulting from daylighting, occupancy controls, and lighting design; and an assessment of the lighting and daylighting design and controls for specific zones.

\subsubsection{Installed Lighting Performance at End Use}

A principal metric in the evaluation of the lighting and daylighting systems is the energy consumption of these systems. Figure 6-27 shows the contribution of the lighting load to the total building load from March 1, 2001 through February 28, 2002. The total installed interior and exterior lighting was responsible for $13 \%$ of the total building load, and consumed $16,058 \mathrm{kWh}(57,808 \mathrm{MJ})$, or $4.0 \mathrm{kBtu} / \mathrm{ft}^{2} \cdot \mathrm{yr}$ $\left(45 \mathrm{MJ} / \mathrm{m}^{2} \cdot \mathrm{yr}\right)$. The outdoor and parking lot lights were responsible for $47 \%$ of the total lighting load for the building because the outdoor lights were operated constantly during nighttime hours. The building lighting load (emergency, indoor, and auditorium lights) comprised $6.2 \%$ of the total building consumption and consumed 7,568 $\mathrm{kWh}(27,245 \mathrm{MJ})$ or $1.9 \mathrm{kBtu} / \mathrm{ft}^{2} \cdot \mathrm{yr}\left(22 \mathrm{MJ} / \mathrm{m}^{2} \cdot \mathrm{yr}\right)$. As a general lighting performance metric, this indicates high-performance lighting and daylighting design and 
operation. In comparison, according to the 1995 CBECS database, the lighting site energy intensity in all educational buildings was $15.8 \mathrm{kBtu} / \mathrm{ft}^{2} \cdot \mathrm{yr}\left(179 \mathrm{MJ} / \mathrm{m}^{2} \cdot \mathrm{yr}\right)$. EIA did not provide energy end use intensities in the 1999 CBECS.

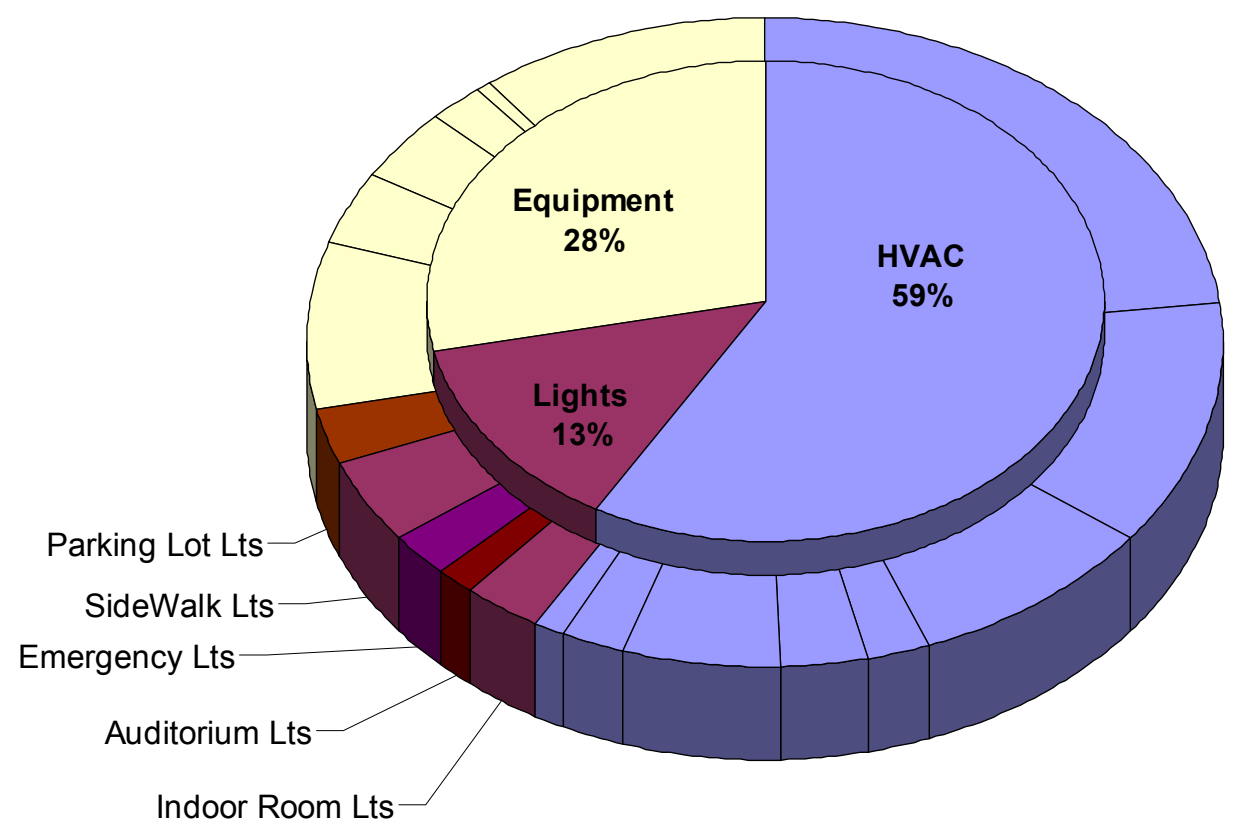

Figure 6-27 Annual lighting end use distribution

To determine the average daily pattern of lighting energy end use, an annual energy use load shape profile (Figure 6-28) was considered. This figure depicts an hourly average lighting consumption profile, with the end use averaged over all hours from March 1, 2001 through February 28, 2002. On average, the daily lighting energy peak of $3.0 \mathrm{~kW}$ occurs around 9:00 or 10:00 p.m., because the exterior lights are on and classes are held at night. The nighttime emergency light base load was attributed to the exterior entrance lights that are mounted to the building, which were on during the night. The small 100- to 200-W average indoor lighting load at night was attributed to the occasional occupant error, where indoor lights were sometimes left on overnight. This resulted in the small annual average nighttime indoor lighting load and is discussed later in the lighting control section, Section 6.4.2.5. In general, the indoor and auditorium lighting profile mirrored building occupancy. 


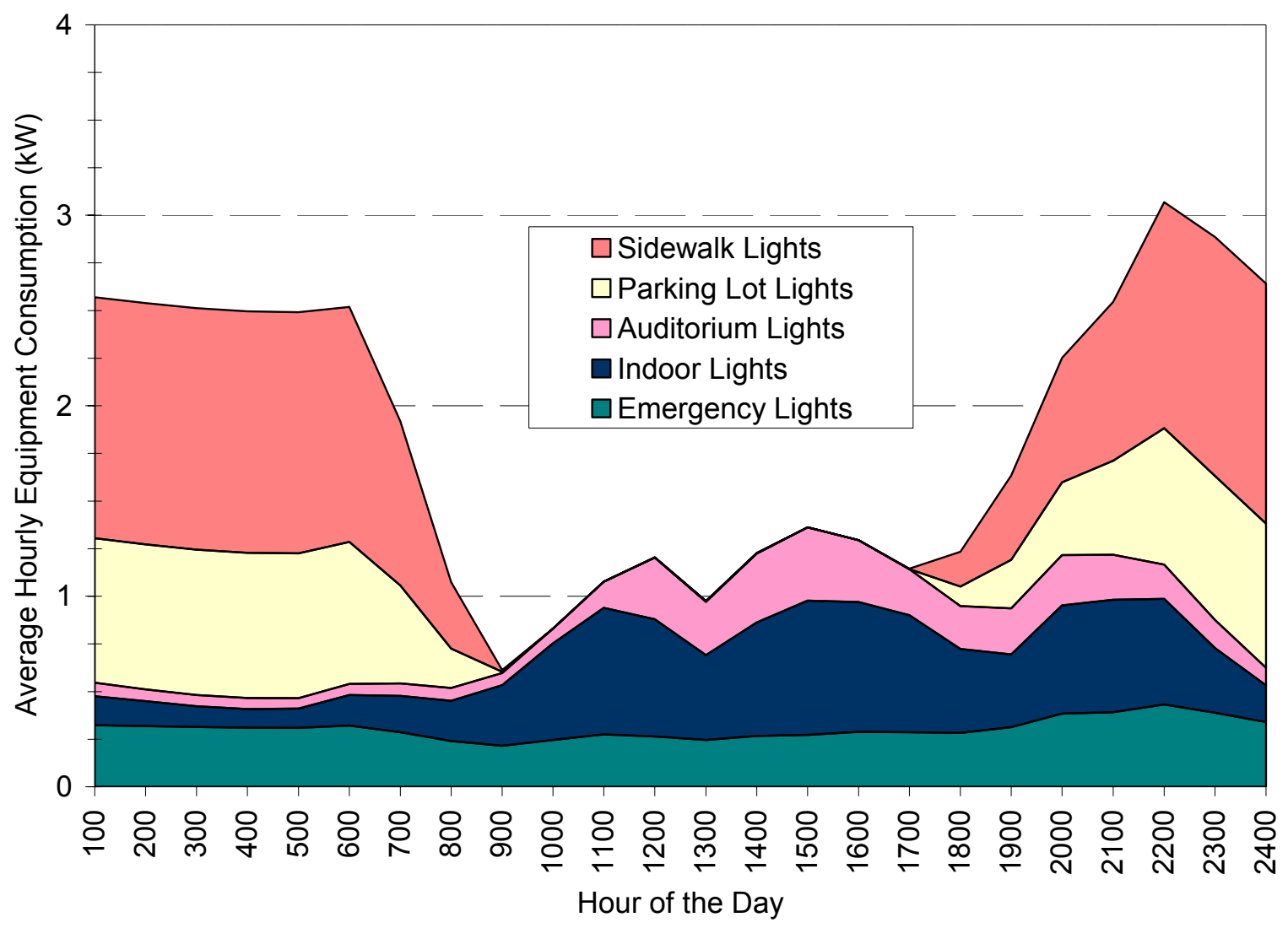

Figure 6-28 Annual lighting end use load shape profile

Table 6-4 presents a monthly summary of the lighting energy consumption over the annual end use monitoring period. The total lighting category was the sum of all the measured lighting end use categories. The building lighting category was the sum of the connected building lighting loads (auditorium, emergency, and indoor room lights).

The monthly trends in Figure 6-29 show changes in seasonal occupancy. The indoor and auditorium daily average lighting consumption was lower for the summer and during Christmas break when the students were not in class. Also shown is the monthly variation in parking lot and sidewalk lighting consumption. Because these lights were on only at night, the winter months with longer nights see higher parking lot and sidewalk lighting consumption levels than do the shorter summer months. 
Table 6-4 Monthly Lighting Energy Performance Summary, March 2001 through February 2002

\begin{tabular}{|c|c|c|c|c|c|c|c|c|c|c|c|c|c|}
\hline Month & March & April & May & June & July & August & September & October & November & December & January & February & $\begin{array}{c}\text { YTD } \\
\text { totals }\end{array}$ \\
\hline Building Total (KWh) & 25869 & 10060 & 8188 & 4835 & 7758 & 7530 & 7289 & 7538 & 8236 & 9782 & 11969 & 13178 & 122232 \\
\hline Total Lights & 1642 & 1564 & 1386 & 990 & 900 & 1008 & 1208 & 1374 & 1650 & 1552 & 1341 & 1479 & 16093 \\
\hline Building Lights & 882 & 909 & 784 & 446 & 351 & 418 & 586 & 650 & 783 & 615 & 427 & 720 & 7568 \\
\hline Indoor Room Lights & 422 & 384 & 326 & 161 & 121 & 166 & 255 & 316 & 400 & 317 & 179 & 368 & 3413 \\
\hline Auditorium Lights & 151 & 216 & 181 & 81 & 74 & 83 & 150 & 128 & 151 & 75 & 58 & 140 & 1487 \\
\hline Emergency Lights & 310 & 309 & 277 & 205 & 156 & 169 & 181 & 206 & 232 & 223 & 190 & 212 & 2667 \\
\hline Sidewalk Lights & 475 & 408 & 375 & 339 & 334 & 359 & 392 & 456 & 548 & 591 & 577 & 480 & 5334 \\
\hline Parking Lot Lights & 285 & 247 & 226 & 204 & 215 & 231 & 230 & 268 & 320 & 346 & 338 & 280 & 3191 \\
\hline
\end{tabular}

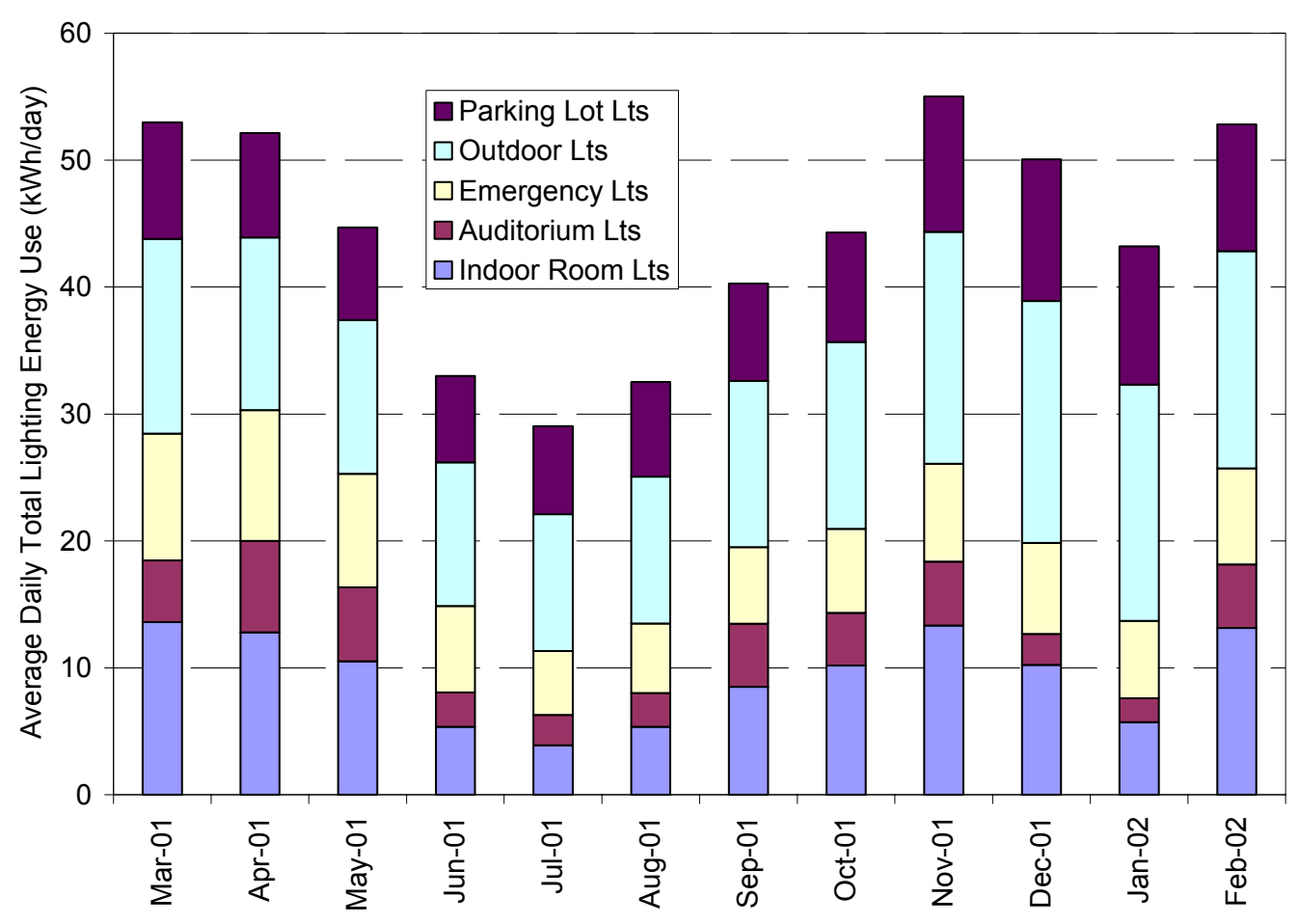

Figure 6-29 Monthly average daily lighting energy end use 


\subsubsection{Calculated Energy Savings Resulting from Lighting and Daylighting Design}

To quantify the success of the Lewis Center's lighting design coupled with daylighting, NREL considered the conventional 2001-2002 Base-case building discussed in previous sections. The Base case predicts the indoor lighting end use consumption in a conventional non-daylit building according to the ASHRAE Standard 90.1-2001. This standard outlines maximum LPD by zone type for new energy-efficient buildings. The Base case predicted that a conventional building would consume $57,765 \mathrm{kWh}$ $(207,950 \mathrm{MJ})$ annually, or $14.5 \mathrm{kBtu} / \mathrm{ft}^{2} \cdot \mathrm{yr}\left(165 \mathrm{MJ} / \mathrm{m}^{2} \cdot \mathrm{yr}\right)$, of total site lighting electricity. We scheduled the lights in the Base case to estimate what the lighting load would have been without daylighting, occupancy controls, and appropriate manual control.

The total site lighting loads were $72 \%$ less than the Base-case building when compared to the measured total annual lighting electricity consumption of $16,093 \mathrm{kWh}(57,935 \mathrm{MJ})$. As the total lighting load for the Base case and the actual building included $2.1 \mathrm{~kW}$ of sidewalk and parking lot lighting not directly related to the building, the lighting savings without including the sidewalk and parking lot lights indicates the actual performance of the building lighting system. In this case, the Base case predicted that a conventional building would consume $50,282 \mathrm{kWh}(177,260 \mathrm{MJ})$, or $12.4 \mathrm{kBtu} / \mathrm{ft}^{2} \cdot \mathrm{yr}\left(141 \mathrm{MJ} / \mathrm{m}^{2} \cdot \mathrm{yr}\right)$, in building-related lighting electricity. Compared to the measured indoor building annual lighting electricity consumption of $7,568 \mathrm{kWh}(27,250 \mathrm{MJ})$, the building lighting loads were $84 \%$ less than a conventional building.

The lighting consumption savings were attributed to good lighting and daylighting design and operation, as the Lewis Center incorporates a reduced LPD (actual LPD) and daylighting design strategies with occupancy controls that are not included in the conventional Base-case simulation. To investigate the savings from the actual LPD, NREL compared the Base-case model, which included the LPD shown in Table 6-5, to a Base-case model using the actual LPD. The only difference between the actual LPD Base-case model and the ASHRAE 90.1-2001 Base-case model was the difference in LPD as shown in Table 6-5. For the Base-case building, the average building LPD is $1.2 \mathrm{~W} / \mathrm{ft}^{2}\left(13 \mathrm{~W} / \mathrm{m}^{2}\right)$ and the actual LPD is $0.79 \mathrm{~W} / \mathrm{ft}^{2}\left(8.5 \mathrm{~W} / \mathrm{m}^{2}\right)$. The LPD for these base cases did not include $2.1 \mathrm{~kW}$ of sidewalk and parking lot lights.

Table 6-5 Base case and Actual Lighting Power Density by Space

\begin{tabular}{|l|c|c|}
\hline \multicolumn{1}{|c|}{ Zone } & $\begin{array}{c}\text { Base-case LPD } \\
\mathrm{W} / \mathrm{ft}^{2}\left(\mathrm{~W} / \mathrm{m}^{2}\right)\end{array}$ & $\begin{array}{c}\text { Actual LPD } \\
\mathrm{W} / \mathrm{ft}^{2}\left(\mathrm{~W} / \mathrm{m}^{2}\right)\end{array}$ \\
\hline \hline Offices & $1.5(16.1)$ & $0.88(9.5)$ \\
\hline Classrooms/Lecture Halls & $1.6(17.2)$ & $1.18(12.7)$ \\
\hline Corridors/Transitions/Other & $0.7(7.5)$ & $0.45(4.8)$ \\
\hline Atrium & $1.3(14.0)$ & $0.93(10.0)$ \\
\hline Total Building $^{1}$ & $1.2(12.9)$ & $0.79(8.5)$ \\
\hline
\end{tabular}

${ }^{1}$ Does not include $2.1 \mathrm{~kW}$ of sidewalk and parking lot lights.

When NREL simulated the actual LPD Base-case model, it expected an annual lighting consumption of $32,470 \mathrm{kWh}(116,890 \mathrm{MJ})$, which was 34\% less than the ASHRAE 90.1-2001 Base-case lighting prediction. The reduced LPD resulted in this 34\% lighting energy savings. The actual LPD is not as high as ASHRAE 90.1-2001 recommends because the lighting design accounts for a daylighting contribution during the day, includes efficient fluorescent lamps and ballast, and appropriate use of task lighting. The value of the daylighting cannot be underestimated in this savings, as most lighting designs are established based on daytime operations. Although hard to quantify, people find that evening lighting levels can be lower than daytime levels. To ensure that the LPD was not too low, the evaluators measured the quality of lighting and daylighting, which is discussed in the following sections and in Appendix D. In general, daylighting combined with electrical lighting, was able to provide sufficient illuminance. During periods of no daylighting contribution (nighttime and cloudy sky), the electric lights provide lower levels of 
illuminance than recommended by IESNA (IESNA 2000) (illuminance levels are shown in Section 6.4.2.6). Although classroom nighttime illuminance levels were lower than recommended, the occupants were not uncomfortable with the lower lighting levels that result from the reduced LPD because a high indoor to outdoor contrast is possible with less illuminance at night. Furthermore, despite overall lower nighttime lighting levels, the high contrast allows the occupants to be comfortable with the nighttime electrical lights.

A second type of lighting energy savings can be attributed to appropriate control of the installed luminaires. The hallways and stairwells use motion sensors combined with daylighting sensors. The atrium uses manual lighting control. The classrooms have manual dimming, but occupancy control to energize the circuits. In the atrium, occupants only use the lights for evening functions making good use of the daylighting without automatic controls. Figure 6-30 shows the results of this operation.

For zones that are controlled through occupancy sensors with a minimum illuminance hold, such as the second-floor corridor pictured in Figure 6-30, the lights are disabled if the zone receives enough daylight. Because the daylighting sensors and occupancy controls are integrated lighting controls, the savings resulting from these controls were not considered independently.
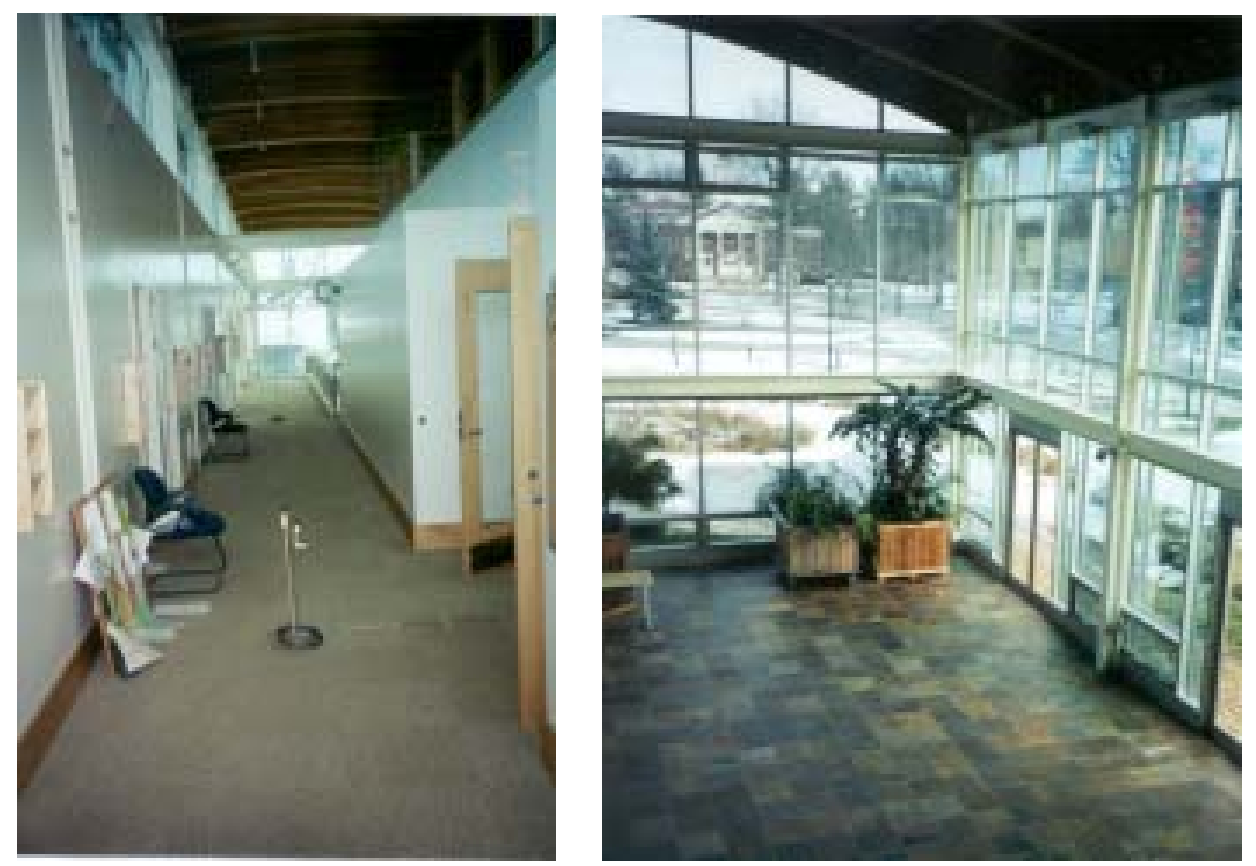

Figure 6-30 Second-floor corridor daylighting and atrium daylighting

To evaluate the savings that accrue from the daylighting and occupancy control strategies, the Base-case model was modified to use the actual LPD, but it did not include occupancy sensors or daylighting. Schedules were not changed from those discussed in Section 5.3.4. The measured building lighting consumption was $76 \%$ less than the predicted actual LPD Base case, as shown in Figure 6-31. The difference between the second year annual measured lighting use and the calibrated TMY2 As-built March 01-February 02 are negligible, as the model was calibrated based on the measured lighting use. Table 6-6 summarizes the annual lighting performance for the various comparisons. Because not all lighting zones use automatic daylighting or occupancy sensors, a portion of these daylighting savings are dependent on manual occupant control. The occupants do not use the atrium lights when daylighting is sufficient, and typically turn lights off when spaces are unoccupied. This type of manual control increases the daylighting savings, but it does provide opportunities for misuse. The assumption that the occupants will provide appropriate control is generally accepted, but periods of mismanagement have been documented, which are discussed in Section 6.4.2.5. 


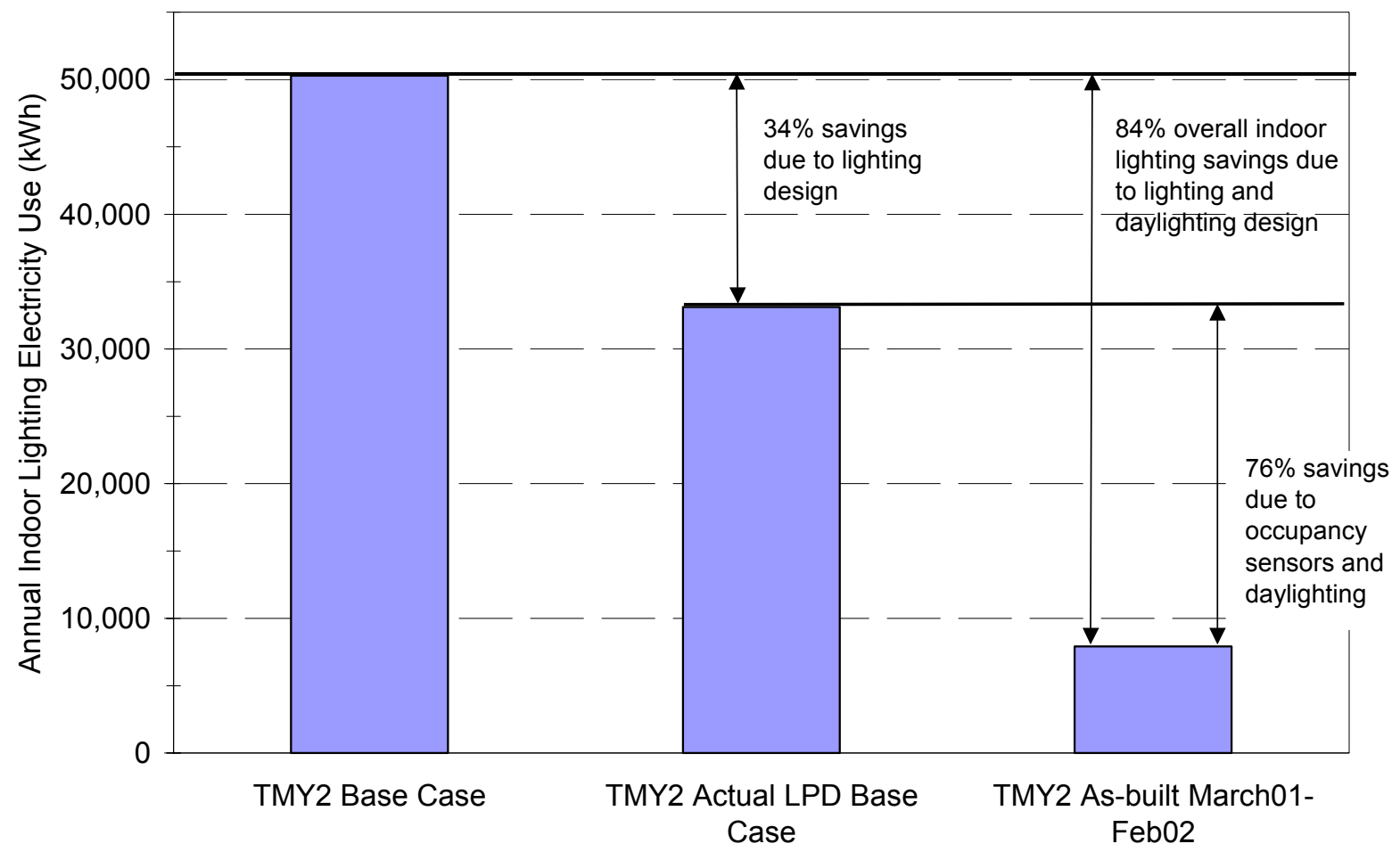

Figure 6-31 Lighting and daylighting design savings for indoor lights

Table 6-6 Annual Lighting Performance Summary

\begin{tabular}{|l|c|}
\hline \multicolumn{1}{|c|}{ Measured and Simulated Lighting Use } & Annual Lighting Use (kWh) \\
\hline March 2001 through February 2002 measured indoor lighting use & 7,568 \\
\hline TMY2 As-built March 01-February 02 simulated indoor lighting use & 7,922 \\
\hline TMY2 simulated Base-case indoor lighting use with ASHRAE 90.1 LPD & 50,282 \\
\hline TMY2 simulated Base-case indoor lighting use with actual LPD & 33,100 \\
\hline
\end{tabular}

\subsubsection{Seasonal Daylighting Performance}

Typically, a primary concern in daylit buildings is the quality, or distribution, of outdoor daylight into the lighting zones. To address this concern, illuminance levels were measured and distribution measurements taken over the range of sun altitude angles, or daylighting seasons. For each of these seasons, different daylighting performance issues were highlighted that relate to each of the three measurement seasons. The results of these measurements are included in Appendix D. The primary results of this analysis are:

- direct-beam daylighting in the classrooms can be controlled by appropriate use of blinds,

- the first-floor classrooms have better daylighting than the second floor because of the white ceiling,

- daylighting in the offices must be supplemented with task lighting,

- daylighting in the second-floor corridor is excellent because of the clerestory windows, and 
- atrium daylighting is abundant, but unwanted glare must be controlled with blinds on the east glass.

\subsubsection{Daylighting Design Assessment}

The daylighting potential of each space was determined by calculating the number of hours that indoor lighting could be provided with only sunlight. This calculation was used to assess the daylighting design. This section discusses only the daylighting design and daylighting potential; the next section discusses the lighting control.

The first step in assessing the daylighting potential was to establish the outdoor illuminance needed to furnish enough light such that no electrical lights were needed. For the office space, the average office illuminance is graphed versus the outdoor illumination for each of the daylighting seasons, as shown in Figure 6-32. This data includes all the office 15-min illuminance measurements taken over the three data collection periods.

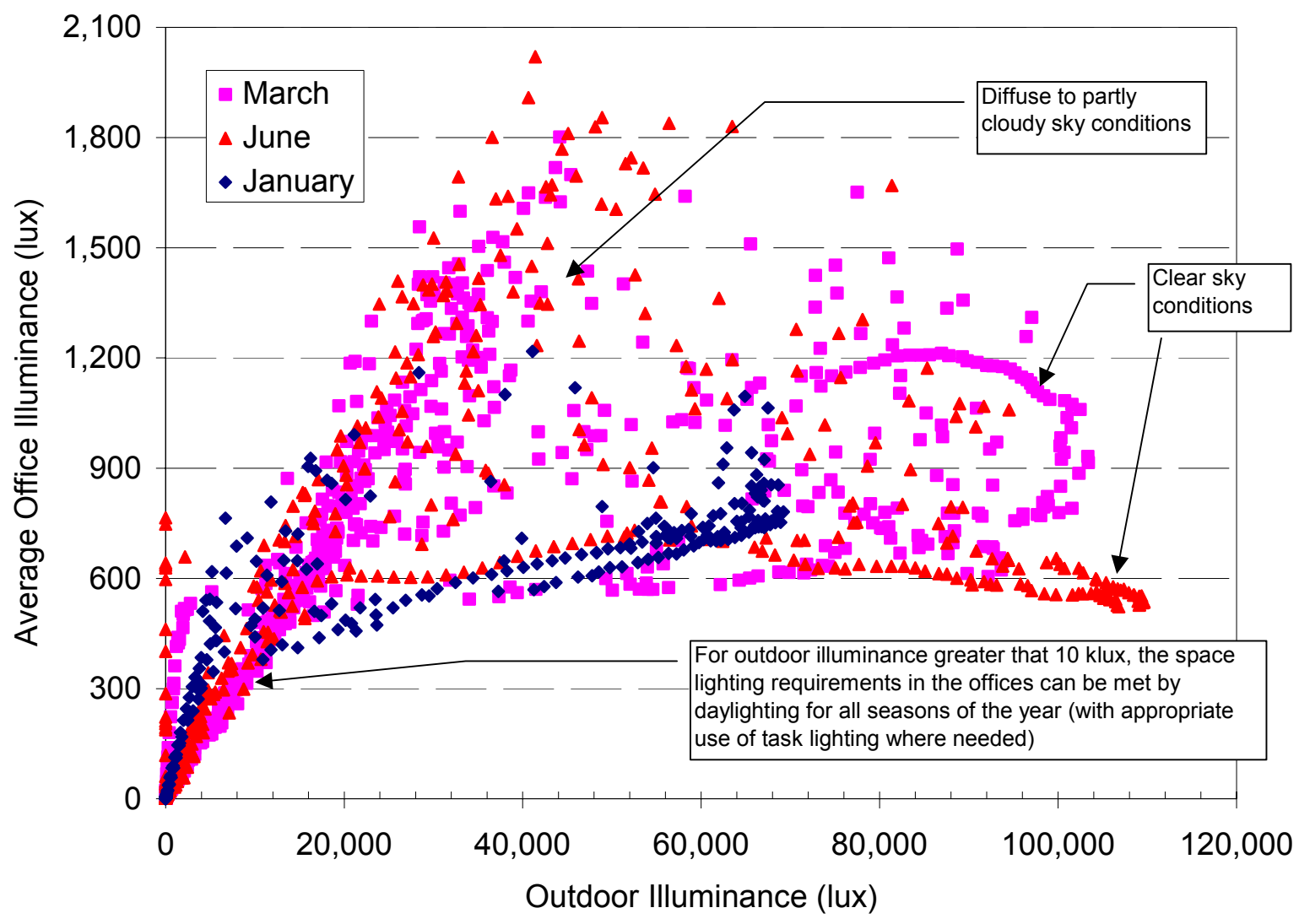

Figure 6-32 Average 15-min office illuminance versus outdoor illuminance

For outdoor illuminance greater than 10 klux, the lighting requirements in the office space can by met by daylighting. This is independent of the season. As this is an average illuminance over the office, task lighting may be needed for darker areas when appropriate. Also shown in Figure 6-32 is the difference in office daylighting for varying sky conditions. As the daylighting is diffuse, the lighting is greater during cloudy sky conditions, because reflections from clouds allow for more diffuse daylighting than from shaded direct-beam sunlight during clear sky conditions. A similar graph shown in Figure 6-33 illustrates 
when the upstairs corridor can be completely daylit. This data includes all the measured corridor illuminance measurements taken over the three data collection periods.

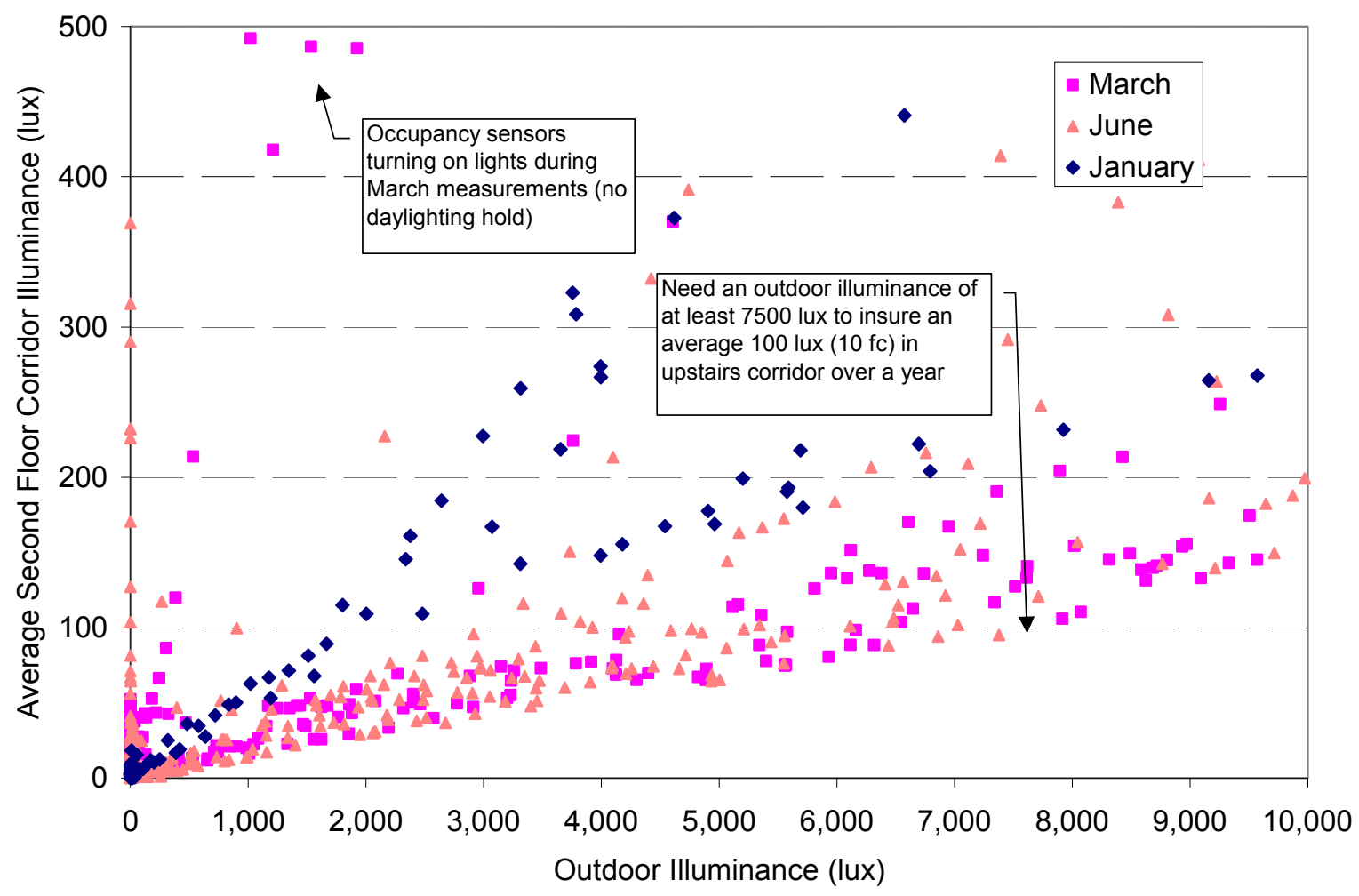

Figure 6-33 Average second floor corridor 15-min illuminance versus outdoor illuminance

For outdoor illuminance greater than 7.5 klux for each daylighting season, the lighting requirements in the second-floor corridor can be met by daylighting. The minimum recommended illuminance level for this space is 100 lux. For the corridor measurements during the spring equinox, the occupancy sensors were not disabled, resulting in an occasional electrical lighting contribution to corridor illuminance. To determine the necessary outdoor illuminance for complete classroom daylighting, each daylighting season was considered separately, as shown in Figure 6-34. The data in Figure 6-34 includes all the measured classroom illuminance measurements taken over the three data collection periods. The classroom was considered completely daylight when the daylighting average of the north row of measurements at locations 1, 4, and 7 was greater than 300 lux. 


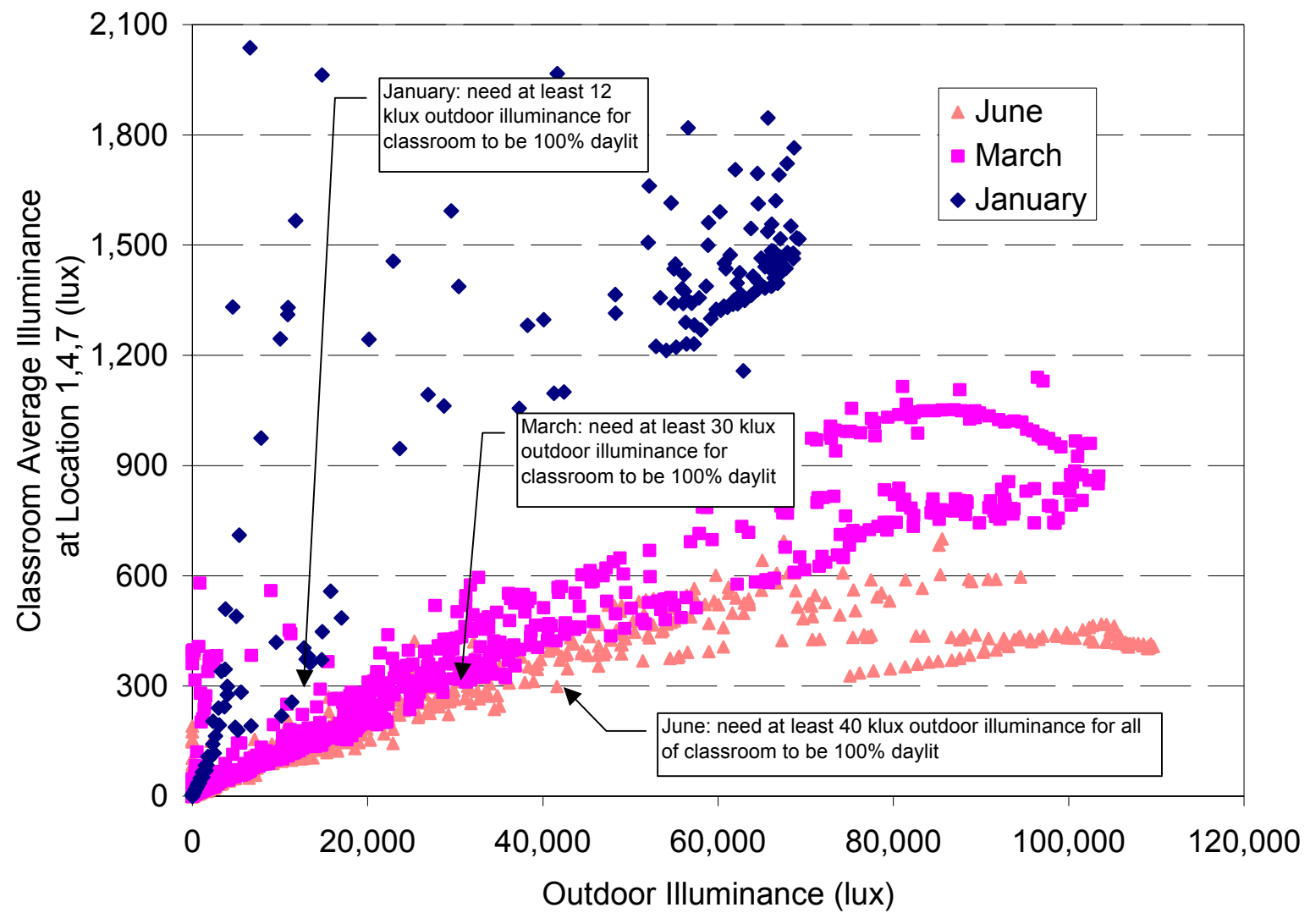

Figure 6-34 North row average seasonal second-floor classroom illuminance versus outdoor illuminance

For the equinox daylighting seasons, the second-floor classroom can be completely daylit when the outdoor illuminance is greater than 30 klux. During the winter solstice when daylighting penetration is the greatest, the second-floor classroom can be completely daylit when the outdoor illuminance is greater than 12 klux. Problems with glare may accompany the winter daylighting, although, as previously shown, appropriate blind management can eliminate unwanted glare while still allowing the space to be daylit. For the summer solstice daylighting season, the classroom can be completely daylit when the outdoor illuminance is greater than 40 klux. The necessary outdoor illumination is greatest for the summer because of the limited daylighting penetration into the north side of the classroom. Some electric light may be needed on the white boards to minimize glare.

By extrapolating the minimum outdoor illumination necessary for complete daylighting to the expected annual illumination, it is possible to quantify the times when the offices, corridors, and classrooms can be completely daylit. Because the outdoor illuminance was not measured continuously, a correlation was developed between the illuminance and the solar radiation. By comparing the measured solar radiation from the weather station to the measured outdoor illuminance from the photometer during the three sets of daylighting measurements, a correlation of visible radiation to solar radiation was determined (Figure 6-35). 


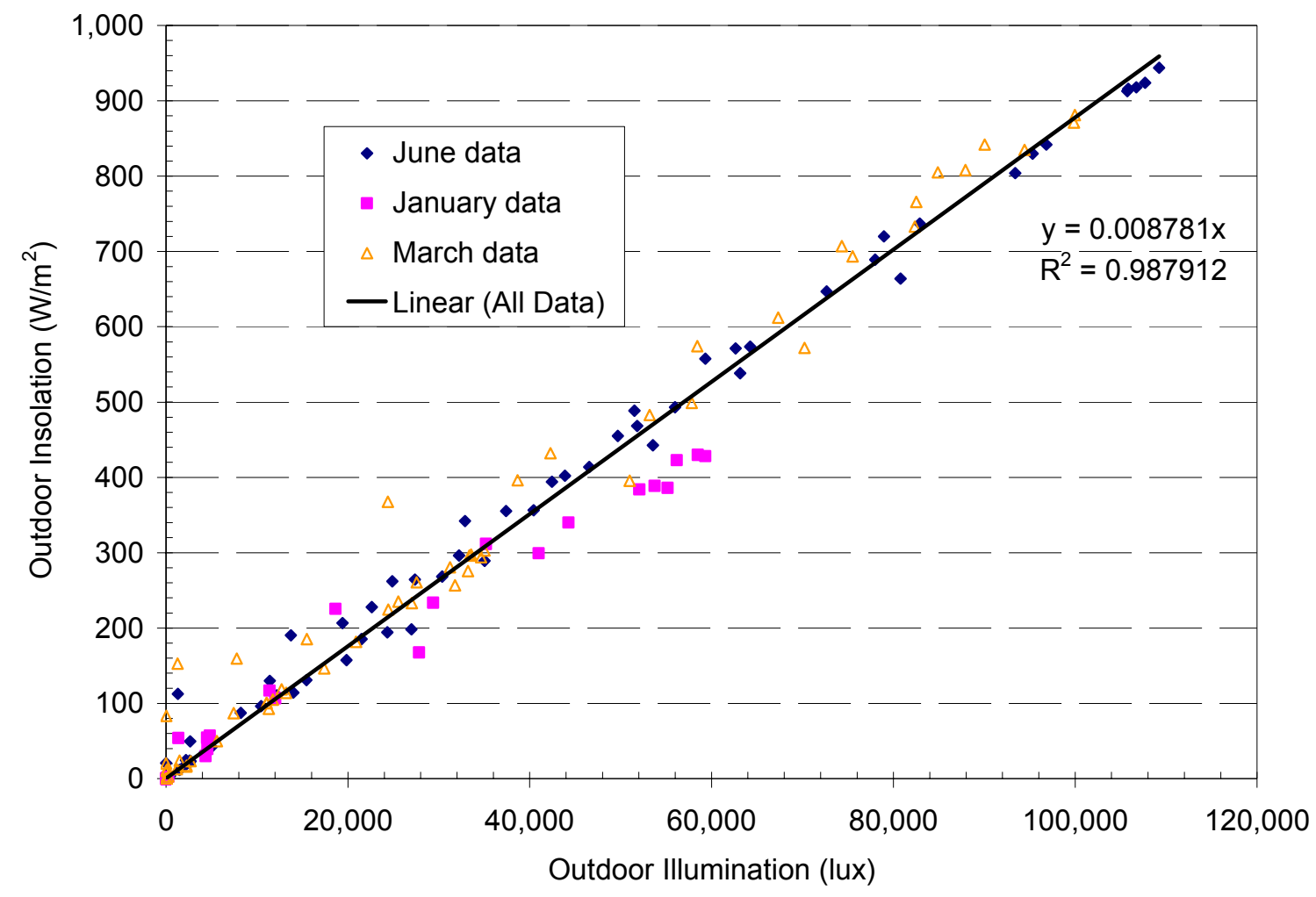

Figure 6-35 Outdoor insolation versus outdoor illuminance

This correlation allows an illuminance distribution to be calculated either over the year or for specific months of the year. Based on the measured solar radiation from March 2001 to March 2002 and the illuminance correlation described in Figure 6-35, the outdoor illuminance distribution for the year is graphed in a histogram at bins of 5 klux, as shown in Figure 6-36. The histogram shows the number of daytime hours (8 a.m. to 5 p.m.) during which the outdoor illuminance is in 5-klux bins from March of 2001 through February 28, 2002. 


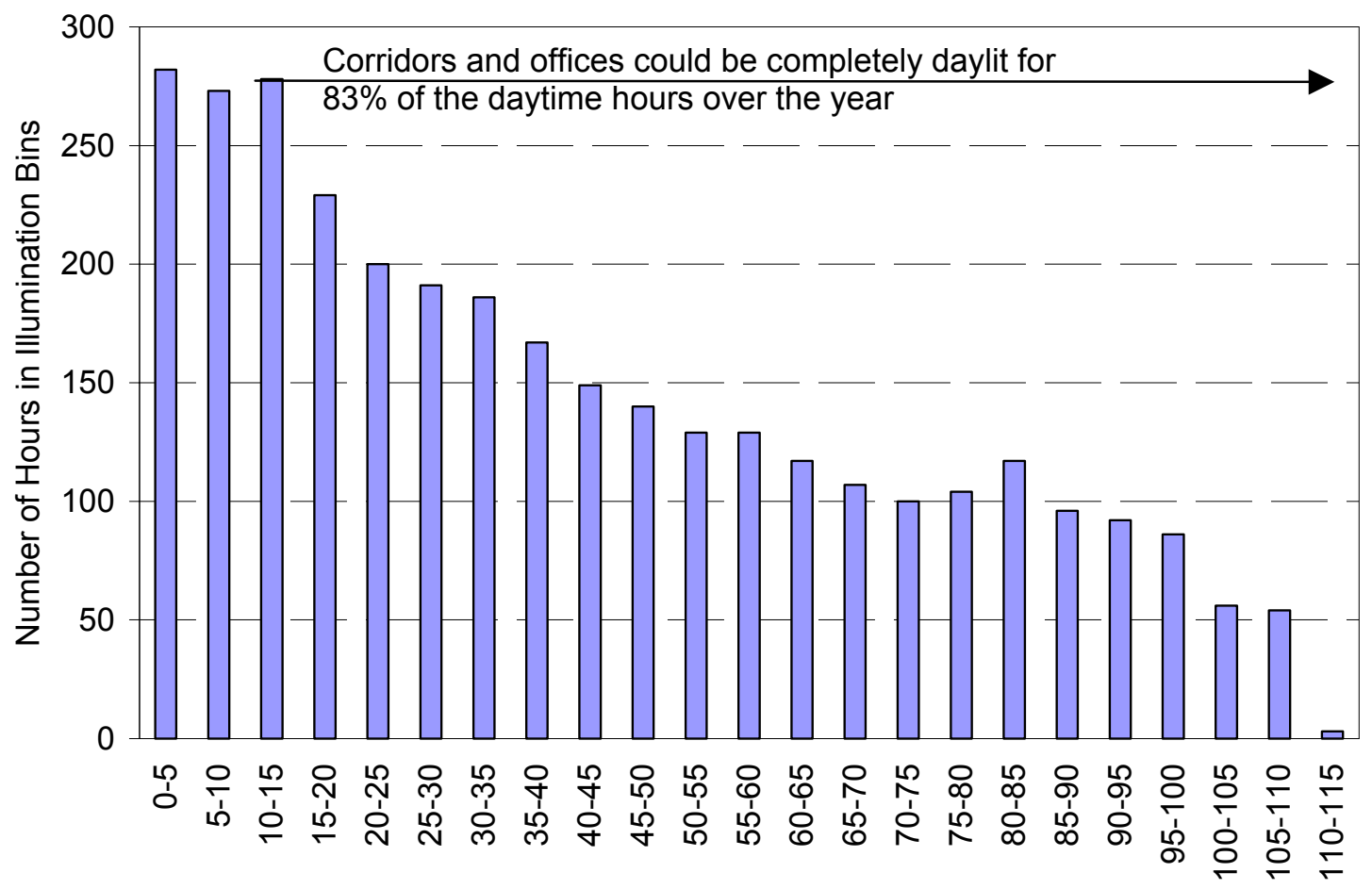

Outdoor Illumination (Klux)

Figure 6-36 Outdoor annual daytime illuminance distribution

The corridors and offices can be completely daylit if the outdoor illuminance is greater than $10 \mathrm{klux}$. The daylighting design in the second-floor corridors and offices allows these spaces to potentially be completely daylit for $83 \%$ of the daytime hours over the year (8 a.m. to 5 p.m.).

Unlike the second-floor corridor and offices, the seasonal variations in second-floor daylighting result in different outdoor illuminance minimums. As shown in Figure 6-34, the outdoor illuminance required for the second-floor classroom to be $100 \%$ daylit varies by season because the daylighting in this space is highly dependant on solar altitude angles, unlike the north side offices and corridors. For a month at the spring equinox, winter solstice, and summer solstice, the percent of daytime hours over each month equal to or greater than each illuminance bin is graphed in the histogram in Figure 6-37. 


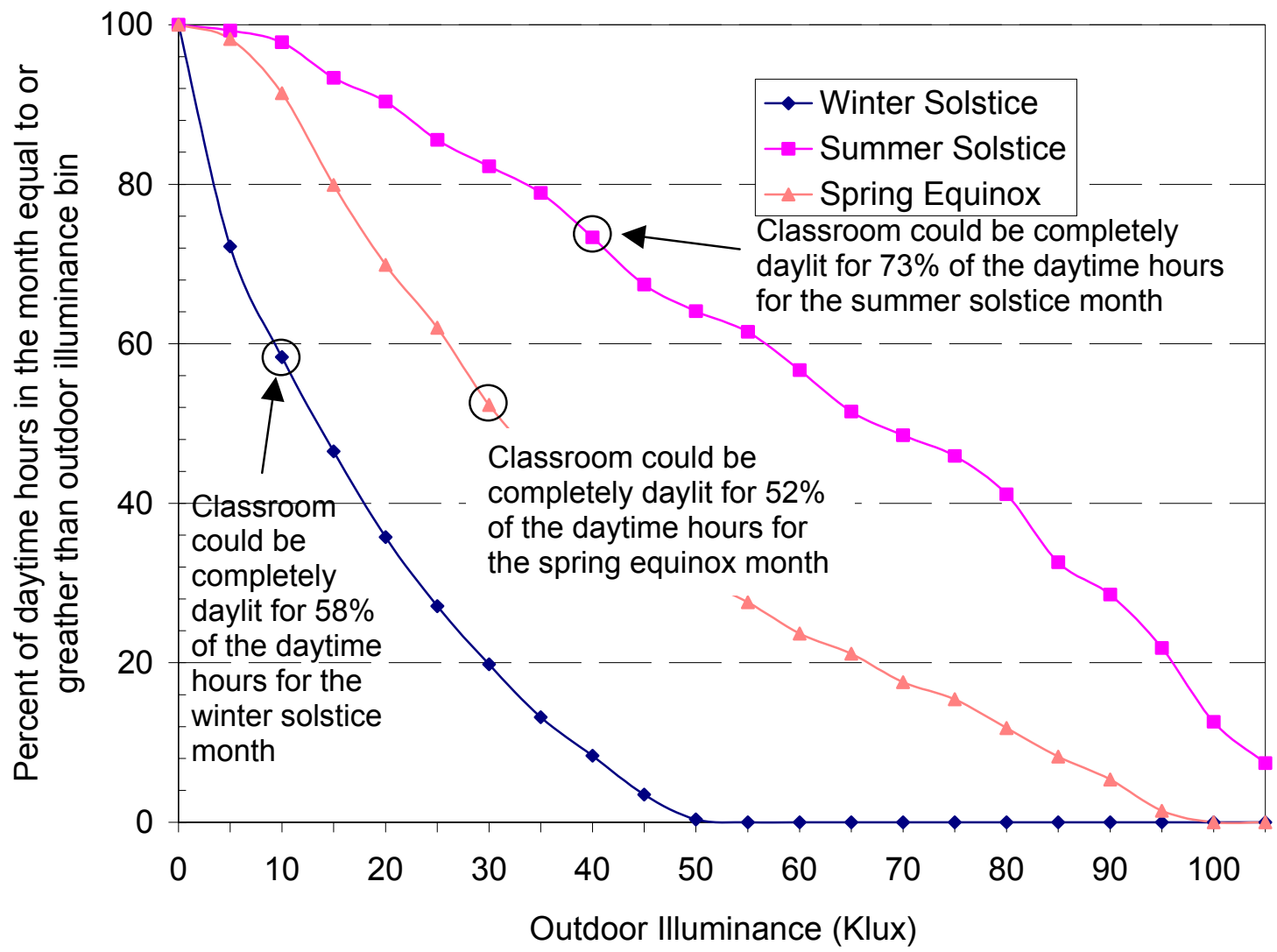

Figure 6-37 Outdoor monthly daytime cumulative illuminance distribution

For a month around the winter solstice, the outdoor illuminance is greater than 15 klux for $58 \%$ of the daytime hours. The daylighting in the second-floor classroom has the potential to supply all the necessary lighting requirements for $58 \%$ of the daytime hours. For a month at the spring equinox, the outdoor illuminance is greater than 30 klux for $52 \%$ of the daytime hours. For this month, the daylighting in the second-floor classroom has the potential to provide all the necessary lighting requirements for $52 \%$ of the daytime hours. For a month at the summer solstice, the outdoor illuminance is greater than 30 klux for $73 \%$ of the daytime hours. For this month, the daylighting in the second-floor classroom has the potential to furnish all the necessary lighting requirements for $73 \%$ of daytime hours.

These results can be applied to first-floor classrooms, as the daylighting design in this space is better than in the second-floor classrooms because of the dark ceiling in this space (see Figure D-10). The glare from low-sun angles in the first-floor classrooms is controlled through blinds.

Based on handheld measurements in the atrium, the atrium has the potential to be completely daylit from 8 a.m. to 5 p.m. year round. To realize the potential daylighting for each of these spaces, the electric lights have to be controlled appropriately.

Daylighting can provide adequate illumination under the majority of daytime conditions in the atrium, classrooms, offices, and corridors. For periods with low outdoor illuminance, supplemental indoor electrical task and space lighting is needed for adequate desktop illuminance levels. To manage glare in the winter months in the south lighting zones, appropriate use of shading devices can solve most glare problems. 
The energy used to light the auditorium was $20 \%$ of the total indoor lighting energy use. Daylighting was not designed into this space, and consequently, the auditorium suffered from additional energy consumption. We would expect daylighting savings similar to the classroom daylighting savings if the auditorium were daylit.

\subsubsection{Evaluation of Electrical Lighting Controls}

To realize a reduction of lighting electricity consumption through daylighting design, appropriate lighting control is necessary. The initial, as installed, lighting control system in the classrooms, corridors, and resource center was controlled only through occupancy sensors. When the occupancy sensor detected movement, the lights would automatically turn on to $50 \%$ power in the classrooms and $100 \%$ in the corridors. Manual controls in the classrooms were then used to increase or decrease the lighting level. This control configuration resulted in unnecessary electrical lighting use in the corridors and classrooms, as daylighting alone can often supply adequate illuminance levels during the day. The occupancy sensors in the classrooms and corridors are passive infrared sensors with a built-in light level sensor. As installed, the configuration of the occupancy sensors did not implement the light level control. Rewiring the sensors to control the lights based on occupancy and a minimum light level kept the electrical lights off when adequate illuminance levels were achieved through daylighting. All the occupancy sensors in the corridors, which control the corridor lights and make up the majority of the emergency lights measurement category, were rewired for a daylighting hold on June 23, 2001. Figure 6-38 shows the results of this control change.

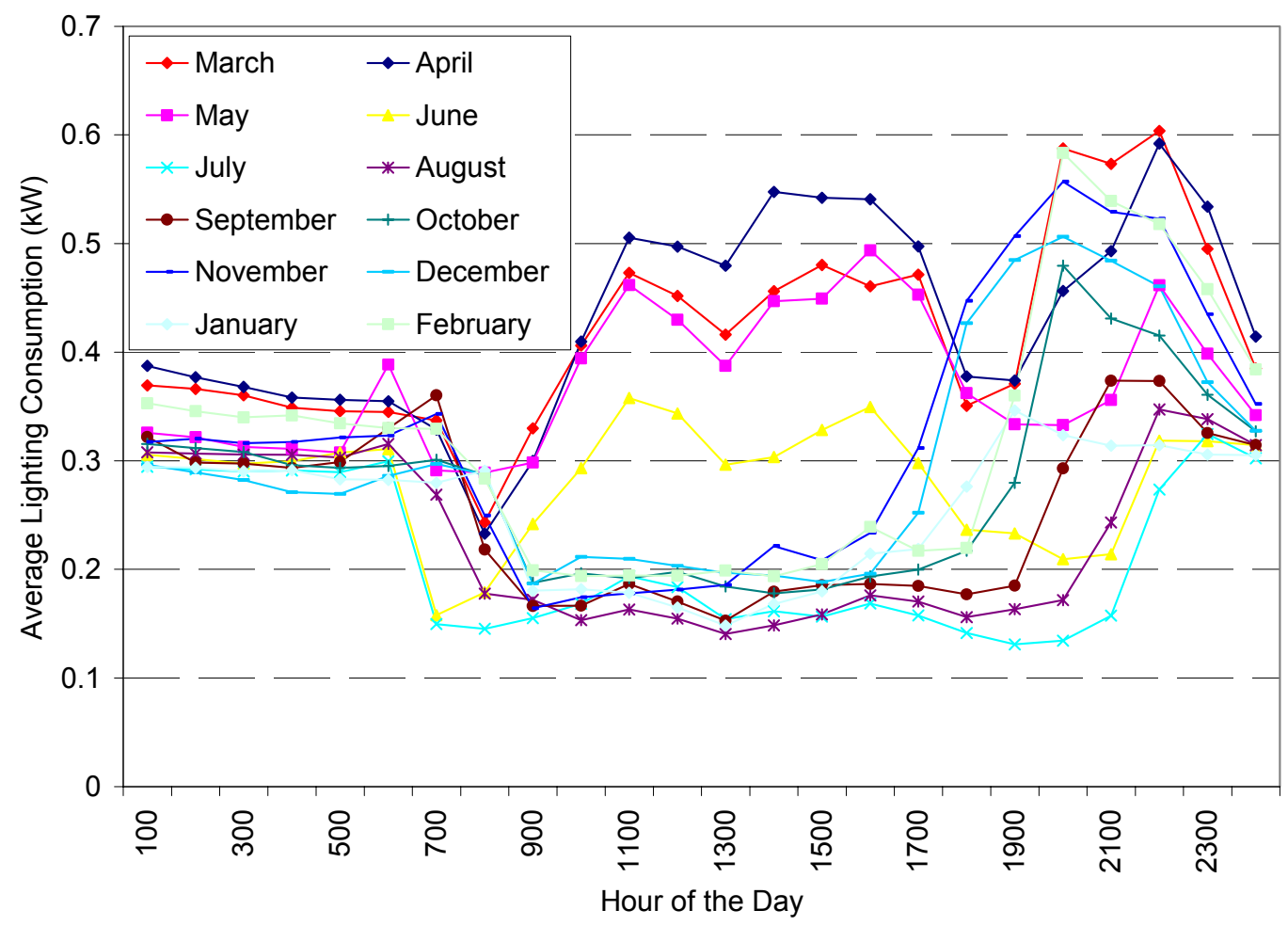

Figure 6-38 Emergency lights monthly load shape profile

After the corridor control change, the daytime consumption of emergency lighting was dramatically reduced. The constant daytime base load, after the control change, is the portion of the auditorium and atrium lights that are measured as emergency lights. A reduction of an average $200 \mathrm{~W}$ or $50 \%$ of the daytime emergency lighting was saved because of this control change. By switching the corridor lighting 
controls from occupancy to occupancy with daylighting, the electric lights remain off when daylighting can achieve adequate illuminance levels. The daylighting controls result in a low daytime emergency lighting use as compared to typical nighttime use. The nighttime and early morning use shown in Figure 6-38 is due to emergency exterior lighting that is not controlled by occupancy sensors. These exterior entryway lights are on all night and turned off during the day, similar to the parking lot and sidewalk lighting.

This control change was also made to the classroom area lights (PF1) on January 5, 2002, and similar savings in classroom lighting were subsequently observed. The classrooms are equipped with manually controlled dimming fixtures. Currently, the daylighting controls affect only the on or off condition of the lights. Additional savings could be achieved by integrating a photocell with automatic dimming of the lights.

To realize the potential daylighting and resulting reduction in lighting electricity consumption in the office spaces, the occupants must control the daylighting manually. Because these lights are controlled through occupancy sensors, the success of the daylight harvesting depends on the occupant.

Another lighting control problem encountered in monitoring lighting consumption at the end uses involved unoccupied nighttime periods where the lights were left on. This occurred mainly in the atrium, as is shown as the indoor room lights category in Figure 6-39. For the nights of February 25 and February 27, the indoor lighting consumption was $1.5 \mathrm{~kW}$. This extraneous use of lighting energy was caused by the manual control of the atrium lights. From March 1, 2001 through February 28, 2002, this was not a serious problem, as building occupants generally exercised appropriate control of the atrium lights when the space was daylit, as well as during the night.

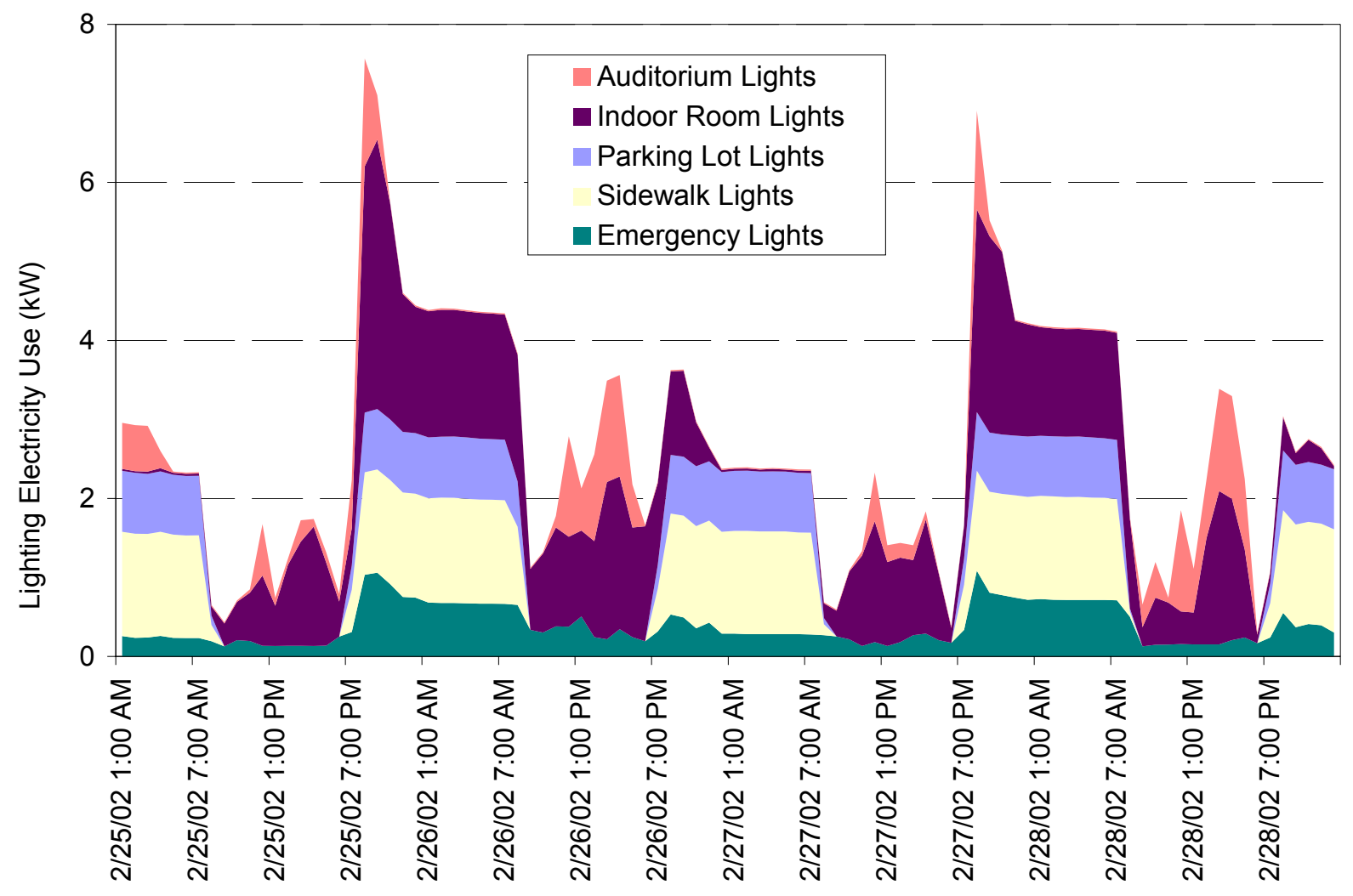

Figure 6-39 Indoor lights on at night from February 25 to 28, 2002 
These daylighting control changes were considered in the calibrated as-built models through hourly scheduling and stepped daylighting controls. The occasional mistake of leaving atrium and auditorium lights on was not included in the as-built models.

\subsubsection{Evaluation of Electrical Lighting Design}

To determine the quantity and quality of the installed electrical lighting in the classrooms, continuous and handheld illuminance levels were measured at night at varying dimmer set points. Figure 6-40 shows the measured illuminance at night with electric lighting in the second-floor classroom at the $50 \%$ power setting (default) and the maximum $100 \%$ power setting. Illuminance at full power changes by a factor of two from about 300 lux to about 600 lux, depending on whether the desk location is centered under a row of lights (7-9) or centered between lights (1-6). The desktop illuminance levels were generally adequate, but the uniformity was not as good. The illuminance level at 50\% power ranges from about 60 lux to about 120 lux. These lighting levels were not adequate for normal nighttime usage of the classroom. Occupants will probably choose the maximum power setting at night. Electric power in the second-floor classroom was measured as $500 \mathrm{~W}$ at $50 \%$ power and $1,000 \mathrm{~W}$ at $100 \%$ power.

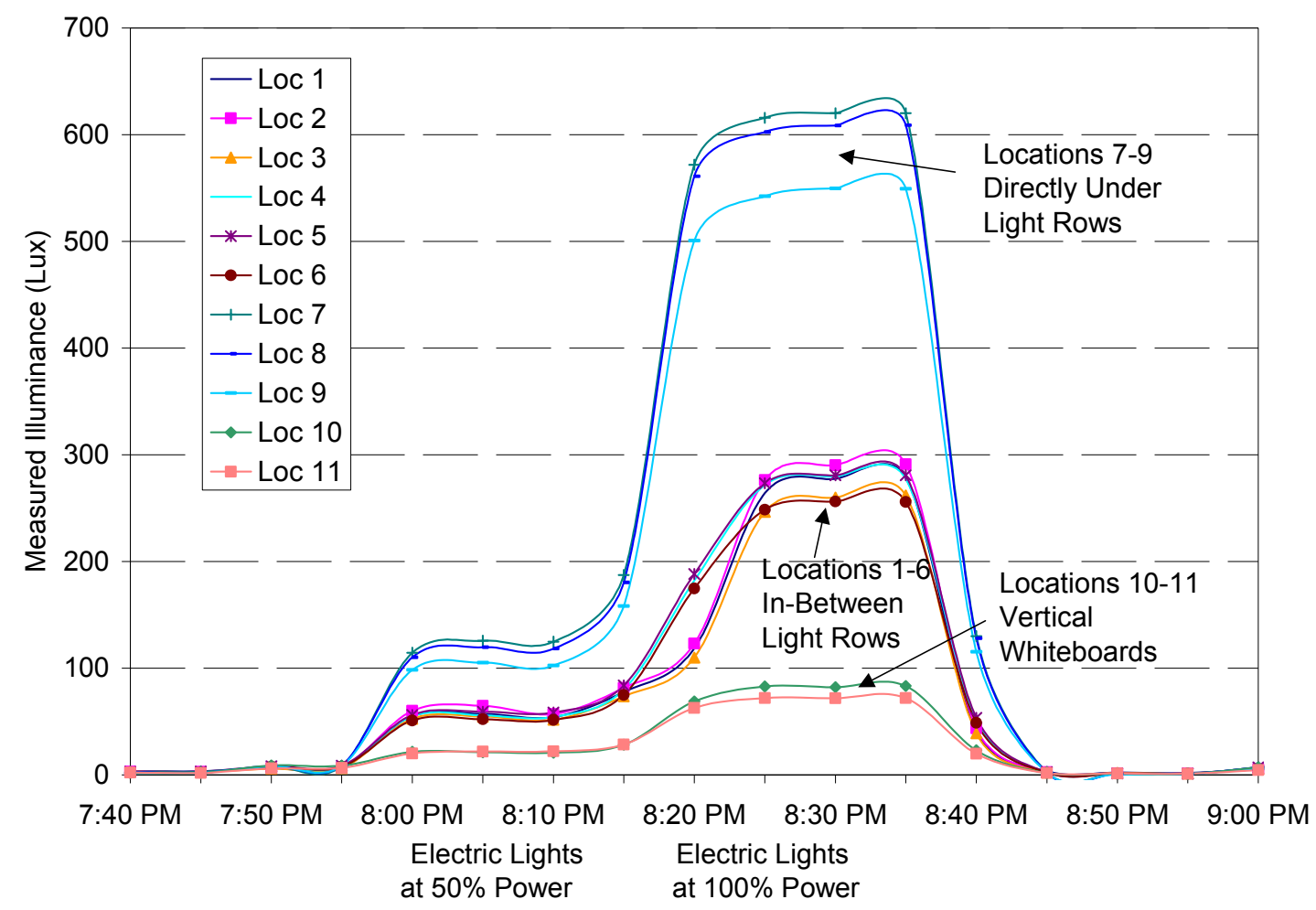

Figure 6-40 Second-floor classroom illuminance measurements with electric lighting only (no daylight present)

The vertical illuminance on the whiteboard at locations 10 and 11 was less than 100 lux (200 lux below recommended minimum) when the second-floor classroom lights were on at $100 \%$ at night. This occurred because there is no direct lighting for this vertical surface. The only electric lighting in the space is furnished by indirect/direct linear T-8 fluorescents and recessed compact fluorescents in the closets.

As previously shown, the illuminance level in the first-floor classrooms was higher and the uniformity was better than in the second-floor classroom. This difference was also evident with the electric lighting illuminance and distribution. The minimum handheld measured illuminance in the first-floor classroom 
was 500 lux when the electric lights were at $100 \%$. This number was attributed to the lower and whiter first-floor classroom ceiling, which reflects up-light down to the work surface, unlike the second-floor classroom's high, less-reflective wood ceilings.

In general, the installed lighting at the lower LPD achieved adequate desktop illuminance levels in the classrooms, although the high, less-reflective wood ceilings in the second-floor classroom resulted in lighting distribution problems. Because the vertical illuminance at the whiteboard in the second-floor classrooms is lower than the recommended illuminance levels, additional task lighting for this surface may be needed if this space is used frequently at night. No complaints have been received regarding the lighting levels, even though they are generally lower than the recommended 300-500 lux. 


\section{Recommendations}

Throughout the monitoring and analysis of the Lewis Center, NREL identified a number of improvements that could be made. These are divided into two categories: equipment issues and operational issues. Some of these issues were addressed as they were identified. NREL developed a list of recommendations to address other issues. These recommendations are based on analysis and observations of the occupants, facility management, and the evaluation team.

\subsection{Implemented Upgrades and Improvements}

The Lewis Center is a heating dominated building, with HVAC responsible for $59 \%$ of the total energy consumed in the building from March 2001 through February 2002. Controlling heating loads, therefore, offered the greatest potential for energy, demand, and cost savings. In response to the documented problem of the electric hydronic system, Oberlin College replaced the hydronic electric boiler with two 8 -ton $(28.2-\mathrm{kW})$, extended range, ground source heat pumps. The hydronic system heat pumps were installed before the 2002-2003 heating season. These heat pumps supply hot water to the radiant floor in the atrium as well as to the other hydronic heating zones, as shown in the upgraded HVAC schematic in Figure 7-1. The original ground source system schematics are shown in Figure 4-15.

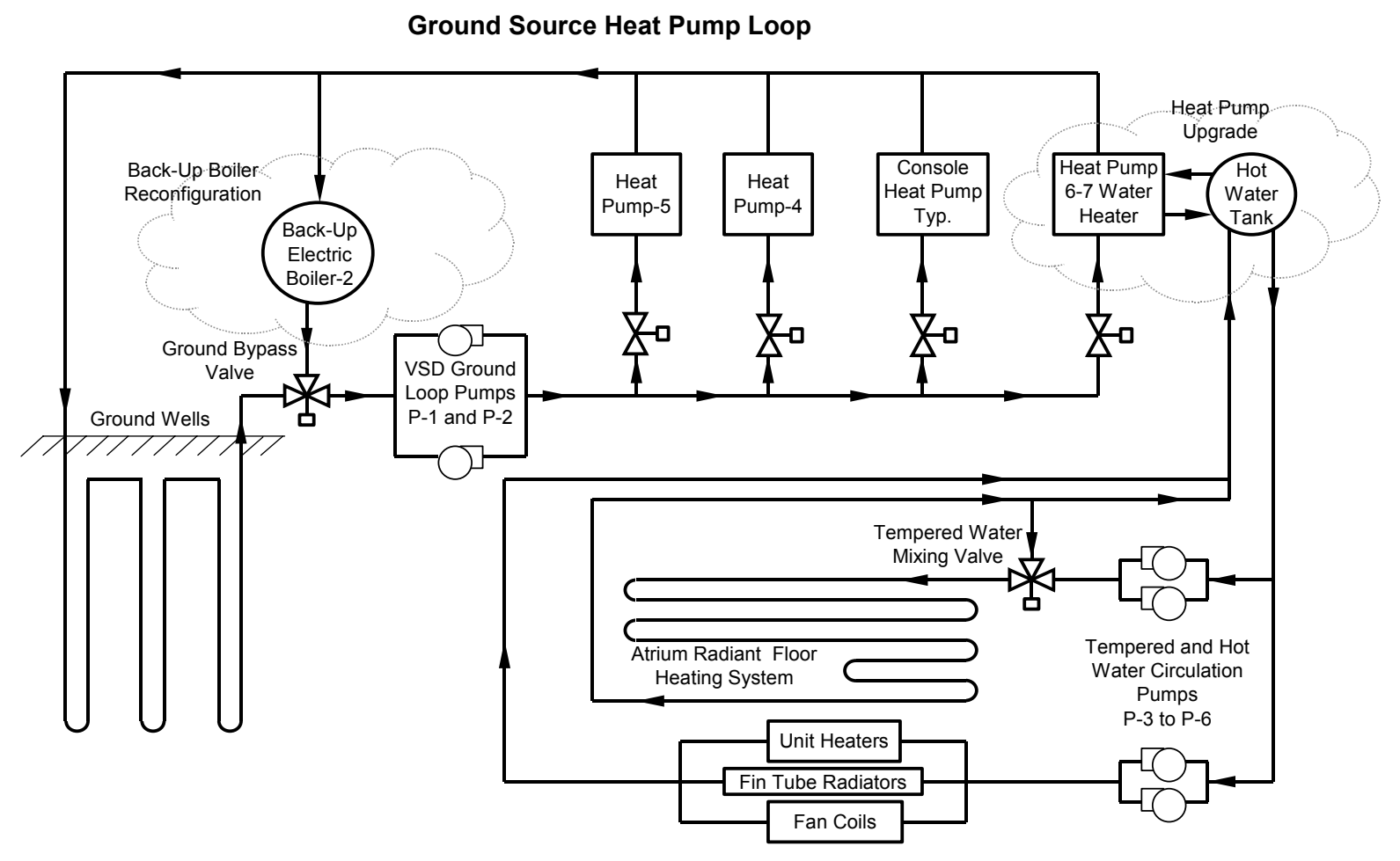

Figure 7-1 Upgraded radiant and ground source heat pump loop piping schematic

NREL estimates a heating end use savings of 35,277 kWh (127 GJ) due to the heat pump upgrade, with heating use from the second to third year reduced by $40 \%$. The energy cost intensity for the third year was $\$ 0.85 / \mathrm{ft}^{2}\left(\$ 9.15 / \mathrm{m}^{2}\right)$, down from $\$ 1.17 / \mathrm{ft}^{2}\left(\$ 12.59 / \mathrm{m}^{2}\right)$ the previous year. The demand charges for the third-year heating season were significantly reduced due to the removal of EB-1. After May 2002, the demand charges did not exceed $\$ 560$, while during the previous heating season the demand changes ranged from $\$ 636.84$ to $\$ 1,247.58$. 
To realize lighting electricity consumption savings through daylighting design, appropriate lighting control is necessary. The initial, as installed, lighting control system in the classrooms, corridors, and resource center was controlled only through occupancy sensors, even though light level controls were available. Rewiring the sensors to control the lights based on occupancy and a minimum light level kept the electrical lights off when adequate illuminance levels were provided by daylighting. All the occupancy sensors in the corridors, which control the corridor lights and make up the majority of the emergency lights measurement category, were rewired for a daylighting hold on June 23, 2001.

Third year energy charges were also reduced by a net-metering agreement that was implemented in April of 2002 with the local utility company. This allowed the Lewis Center to receive credit for any PV electricity exported back to the grid.

A PV system performance degradation issue of the inverters shutting down near peak operating limits was identified and addressed. Occasionally, when the inverters were operating at the maximum power output of $15 \mathrm{~kW}$ AC, they automatically tripped off, and then restarted after 5 minutes. Documented inverter faults were responsible for reducing annual PV production by $1.2 \%$. To fix this problem, the maximum allowable utility voltage inverter set point was increased, as the error code from the inverter indicated a high $\mathrm{AC}$ line voltage fault. NREL monitored the $\mathrm{AC}$ generation efficiencies to verify this set point change was effective.

\subsection{Additional Recommendations}

To continue increasing energy performance, the following further recommendations are provided. These recommendations are prioritized by the potential site energy savings combined with the expected ease and cost of installation. When reasonable, predicted energy savings are included with each recommendation. For recommended operational changes, control strategies are provided based on NREL's experience with optimal controls. The additional recommendations are the following:

1. To reduce the heating demand in the wastewater treatment, exhaust fan control changes are recommended, including controlling the exhaust fan motor with a variable frequency drive. The speed of the exhaust fan will be controlled to keep the wastewater treatment space depressurized with respect to the atrium. The expected result from this change is a reduction of $75 \%$ in fan energy (Anacon Systems 2003), as well as a reduction in heating demand for the space. As the wastewater treatment exhaust fan consumed more than $6,000 \mathrm{kWh}(21,600 \mathrm{MJ})$ during the measurement period, a $75 \%$ reduction in fan energy would result in $4,500 \mathrm{kWh}(16,200 \mathrm{MJ})$ of exhaust fan energy savings. Reducing this fan energy also improves the air flow balance on the enthalpy wheel energy recovery.

2. We recommend investigating scheduling, control changes, and lighting technologies of the parking lot and sidewalk lights. These lights are the single largest lighting use and a good candidate for energy conservation efforts. Currently, these lights are controlled by a photo sensor that turns them on at night. Additional scheduling could turn them off during the middle of the night, with motion sensors to turn them on when needed. Lighting technologies compatible with occupancy sensors would be required for this type of control. Reducing operating time by a half would save $4,263 \mathrm{kWh}$ $(15,347 \mathrm{MJ})$ annually.

3. Energy-efficient PV system isolation transformers are recommended. This type of transformer is expected to reduce nighttime transformer losses by $2,600 \mathrm{kWh}(9,360 \mathrm{MJ})$ while increasing total PV conversion efficiency by $2 \%$. These energy-efficient transformers also have a smaller inrush current, which may also solve the circuit breaker trips. By reducing the inrush current, the PV system can be disconnected when it is dark, eliminating the night stand-by losses from the transformers.

4. As previously shown, the installed ARI-320 heat pumps typically operate outside the recommend source water temperature range. To rectify this problem, appropriately rated ARI-330 ground source heat pumps are recommended (ARI 2003b). Figure 7-2 shows the heating and cooling efficiencies as a function of the entering water temperature for the current and proposed heat pumps. The percent 
reduction of rated capacity as a function of the entering water temperature is also similar to these COP reductions. Properly sized and rated ground source heat pumps would increase the operational efficiency as well as provide operational capacity.

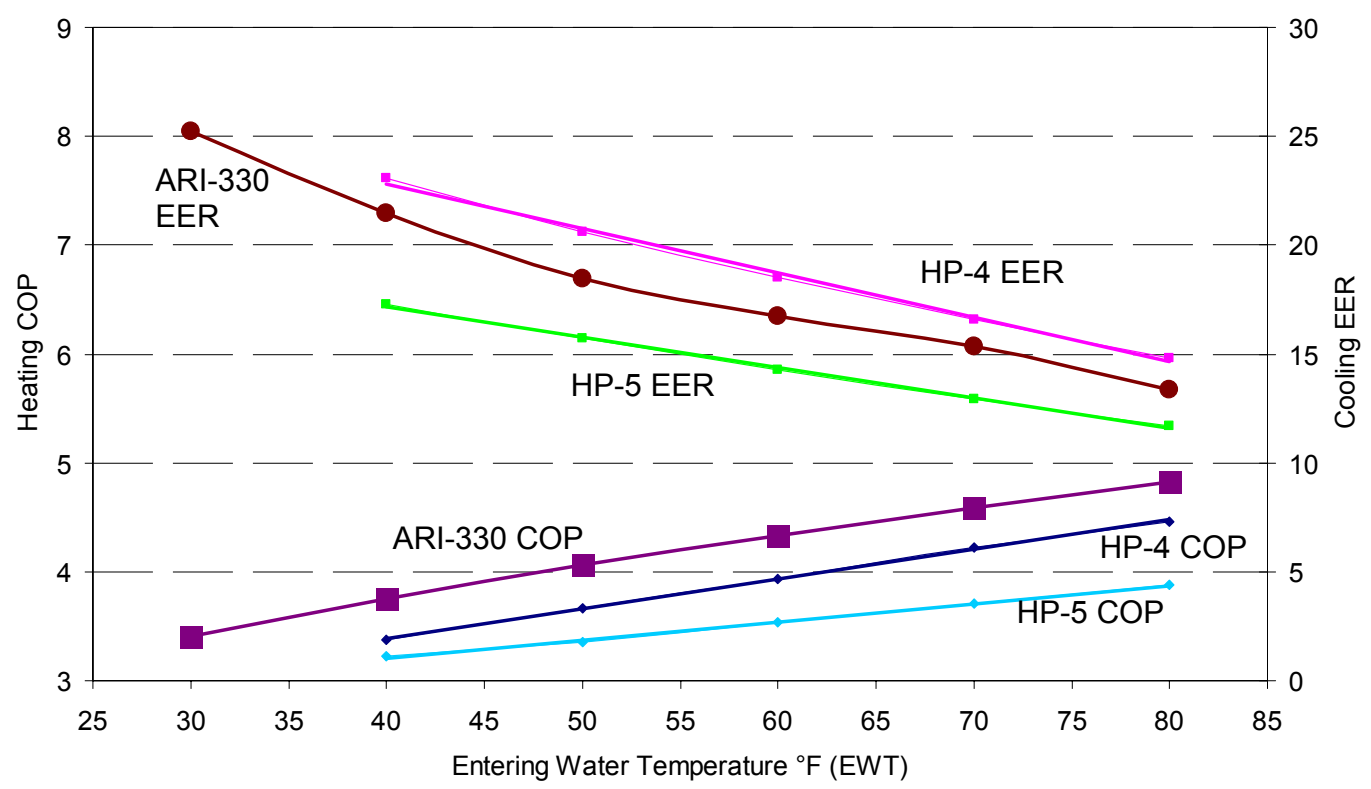

Figure 7-2 Current and ARI-330 rated heat pump heating and cooling efficiencies

The calibrated As-built March 02-February 03 DOE-2 model was modified to determine the effect on annual energy performance of specific recommendations. This model represents the optimized performance of the Lewis Center. The Optimized model included the recommendations of reducing the heating demand for the wastewater treatment by lowering the exhaust air and replacing all the ARI-320 rated heat pumps with ARI-330 heat pumps. Reducing the wastewater treatment exhaust fan could save $17,745 \mathrm{kWh}(63,882 \mathrm{MJ})$ in atrium and wastewater treatment heating and cooling energy use. The Optimized model also predicts savings of $3,749 \mathrm{kWh}(13,496 \mathrm{MJ})$ due to upgrading all of the ARI-320 heat pumps to ARI-330 heat pumps. The model also included 4,500 $\mathrm{kWh}(16,200 \mathrm{MJ})$ savings that accrued from reducing the power requirements of the wastewater treatment exhaust fan with a VSD, 4,263 kWh (15,347 MJ) of savings due to parking lot and sidewalk lighting reduction, and 2,600 kWh $(9,360 \mathrm{MJ})$ savings resulting from energy-efficient isolation transformers. The Optimized model predicts an annual energy consumption of 76,703 kWh $(276,131 \mathrm{MJ})$ with an energy intensity of $19.2 \mathrm{kBtu} / \mathrm{ft}^{2}$ $\left(218 \mathrm{MJ} / \mathrm{m}^{2}\right)$.

A number of operational issues could make better use of the available equipment. Many of these recommendations come from the users not fully understanding the control system and the control developers not fully understanding the building. Additional HVAC control recommendations, based on operational observations, are listed below.

To increase the energy cost savings, NREL recommends developing a demand limiting strategy that integrates on-site generation with HVAC controls. To further utility demand savings, this strategy requires advanced controls that allow the temperature of the building to float based on instantaneous consumption and production:

- Separate the controls of HP-5 and the enthalpy wheel motor and the fan for the enthalpy wheel to allow ventilation when economization is appropriate. 
- Use the $\mathrm{CO}_{2}$ sensors to control outside air to the classrooms. Each classroom already has a $\mathrm{CO}_{2}$ sensor. Operate room dampers based on exceeding the $\mathrm{CO}_{2}$ settings in a classroom. Set the damper to $50 \%$ open when $\mathrm{CO}_{2}$ exceeds the set point. Use $100 \%$ setting when $\mathrm{CO}_{2}$ exceeds the set point by 100 parts per million. Control outside air fan based on the position of these dampers in addition to a weekday schedule for the offices. If no zones need outside air, the fan, ERV, and HP-5 should not operate.

- Operate the enthalpy wheel and related fan only when the outside air temperature is less than $65^{\circ} \mathrm{F}\left(18^{\circ} \mathrm{C}\right)$. The energy required to operate this system is greater than the recovered energy at outdoor temperatures greater than $65^{\circ} \mathrm{F}\left(18^{\circ} \mathrm{C}\right)$.

- Operate outdoor ventilation system for the classrooms and offices in stages based on whether the building is heating or cooling. When the building is in cooling mode and the outdoor temperature is less than the inside temperature, use the enthalpy fans as an economizer for the classroom and office spaces. If these spaces need fresh air, use the enthalpy wheel fans to bring fresh air for stage 1. If the outdoor air is too humid, use HP-5 to dry out the air (mechanical cooling). When HP-5 is off, the bypass damper should be open. If supply air temperature is above $70^{\circ} \mathrm{F}\left(21^{\circ} \mathrm{C}\right)$, use HP-5 to cool down the air. If the supply air is less than $55^{\circ} \mathrm{F}\left(13^{\circ} \mathrm{C}\right)$, use HP-5 to heat the air.

Further lighting recommendations are listed below:

- The atrium should have daylighting controls to keep the lights off during the day. The lights should be manual on with an automatic off for occupancy. Similar automatic off controls based on occupancy should be installed in the auditorium as well.

- Tune the daylighting set points in the classroom and corridor occupancy sensors. This will ensure these lights will provide adequate lighting levels when daylighting is not sufficient and not provide unnecessary electrical lighting when daylighting is sufficient.

- Currently dimming in the classrooms is controlled manually by the occupant. The manual dimming control is only available to the occupants when the daylighting lockout does not override the occupancy sensor. When the motion sensors turn on the classroom lights (only when daylighting does not provide enough light), the lights turn on to a preset level of $50 \%$. The evaluators recommend using the motion sensors to turn lights on to a preset lower level than the current level. The occupant can then use the dimming controls to adjust the illuminance level, balancing it with the daylighting.

- Rehang the blinds in the classrooms such that they do not cover the top row of glass. Install diffusing panels, patterned glass, or laser-cut panels to redirect this light to the ceiling. Lighting in the classrooms could also be enhanced by separating out the view glass from the daylighting glass. Top down/bottom up blinds, as shown in Figure 7-3, can be provided on the view glass for glare control while diffusing or redirecting glass can be used on upper part of the fenestration.
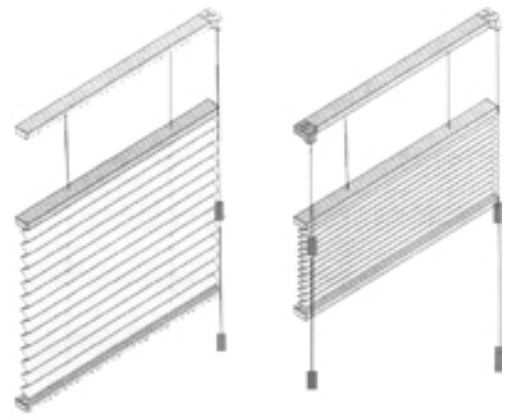

Figure 7-3 Top down and Top down/bottom up blinds 


\section{Conclusions}

\subsection{Measured Whole-building Performance}

As a result of continuous monitoring, analysis, and occupant willingness to fix identified problems, site energy use and costs have decreased significantly over the 3-year life of the building, as shown in Figure 8-1 and Figure 8-2.

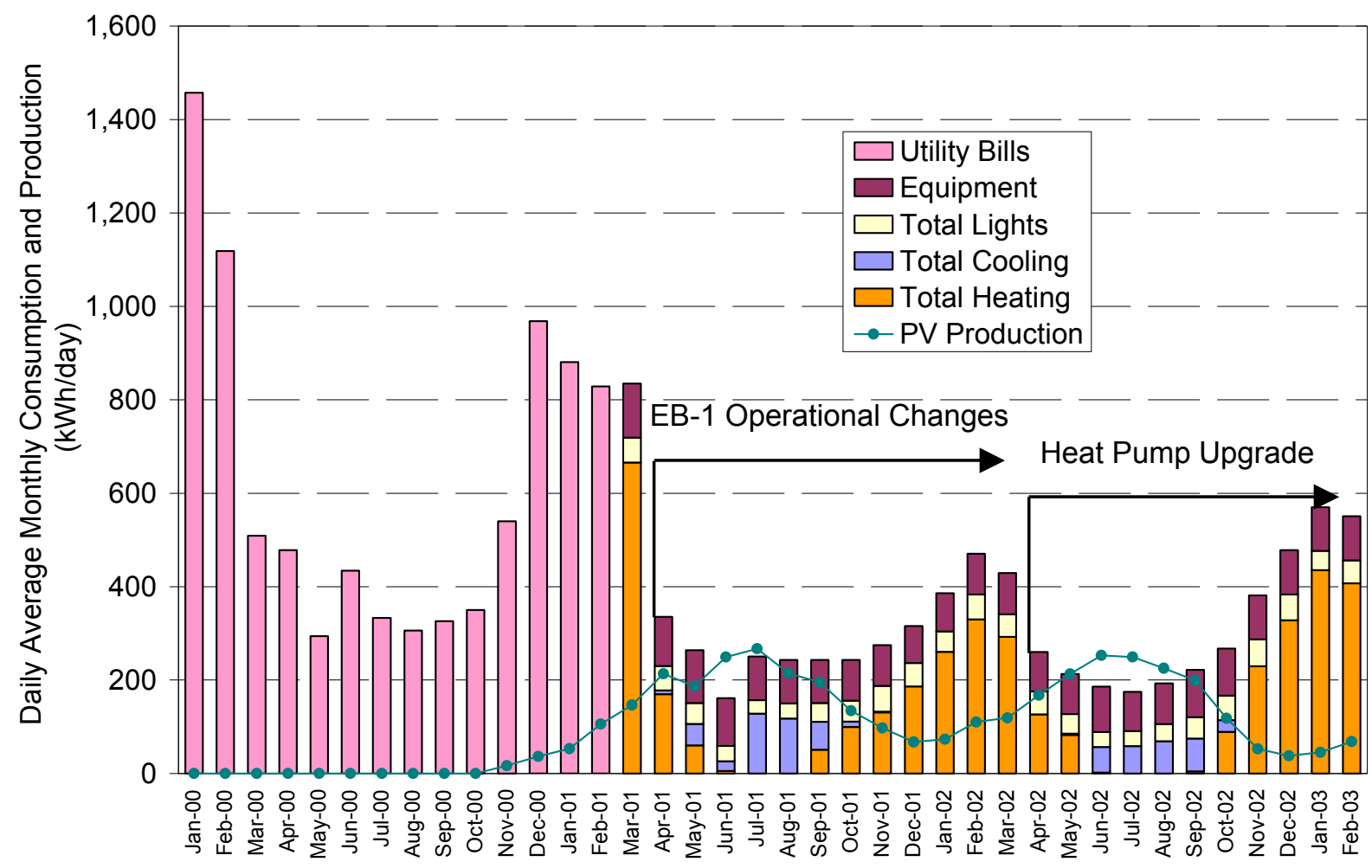

Figure 8-1 Monthly site energy consumption and production, January 2000-February 2003

In April of 2002, a net-metering agreement was implemented with the local utility company. This allowed the Lewis Center to receive credit for any PV electricity exported back to the grid. Before the net-metering agreement, $49 \%$ of the total annual PV production was exported to the grid without credit. 


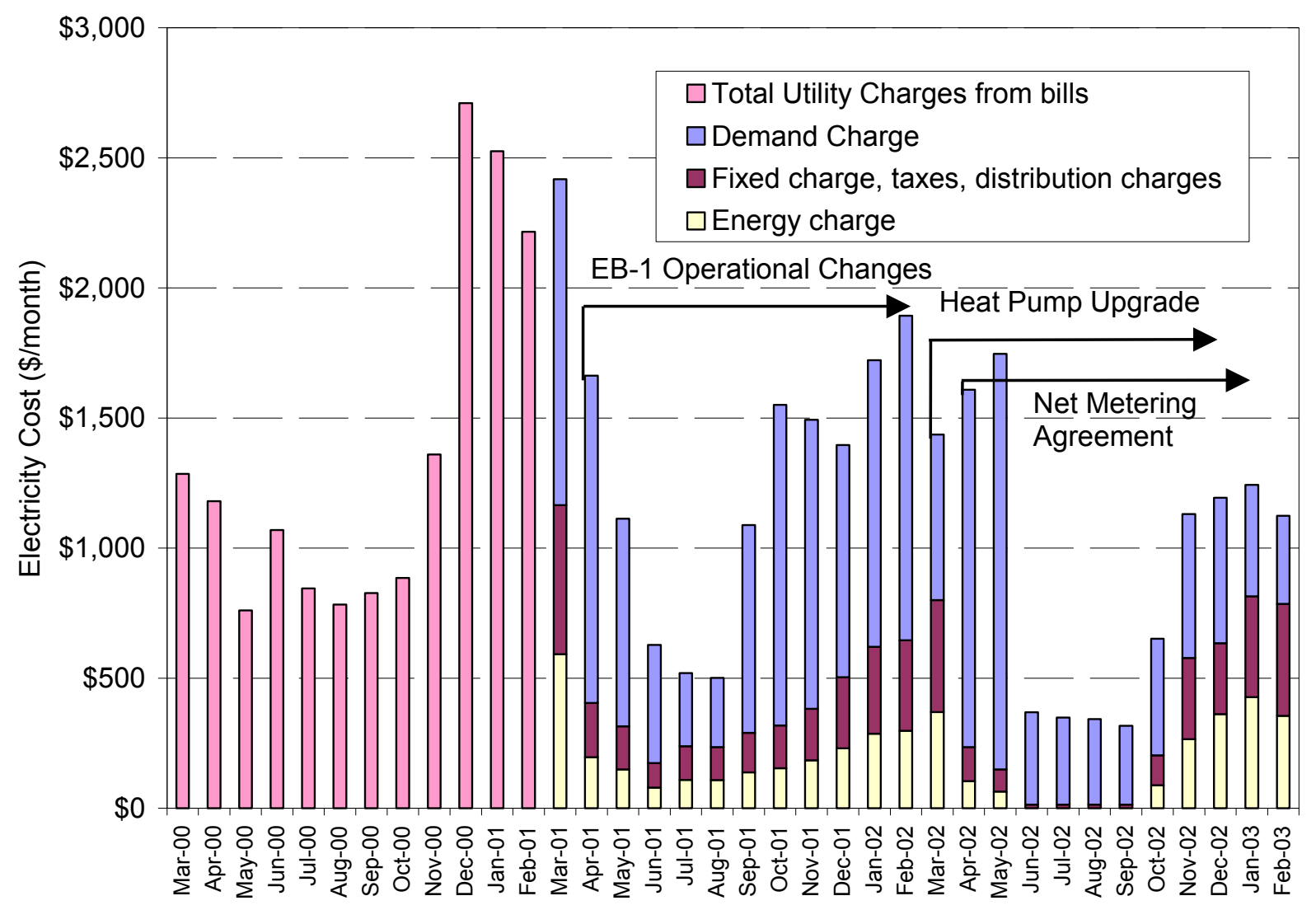

Figure 8-2 Monthly site energy costs, March 2000 through February 2003

Table 8-1 Measured Whole-Building Results: First, Second, and Third Year of Operation

\begin{tabular}{|c|c|c|c|c|c|c|}
\hline & $\begin{array}{c}\text { Measured } \\
\text { Site Use } \\
\text { Intensity } \\
\mathrm{kBtu} / \mathrm{ft}^{2} \\
\left(\mathrm{MJ} / \mathrm{m}^{2}\right)\end{array}$ & $\begin{array}{c}\text { Measured PV } \\
\text { Production } \\
\text { Intensity } \\
\mathrm{kBtu} / \mathrm{ft}^{2} \\
\left(\mathrm{MJ} / \mathrm{m}^{2}\right)^{1}\end{array}$ & $\begin{array}{c}\text { Percent of } \\
\text { Building } \\
\text { Load Met By } \\
\mathbf{P V}\end{array}$ & $\begin{array}{c}\text { Measured } \\
\text { Net Site Use } \\
\text { Intensity } \\
\mathrm{kBtu} / \mathrm{ft}^{2} \\
\left(\mathrm{MJ} / \mathrm{m}^{2}\right)\end{array}$ & $\begin{array}{c}\text { Measured } \\
\text { Source Use } \\
\text { Intensity } \\
\mathrm{kBtu} / \mathrm{ft}^{2} \\
\left(\mathrm{MJ} / \mathrm{m}^{2}\right)\end{array}$ & $\begin{array}{c}\text { Energy Cost } \\
\text { Intensity } \\
\$ / \mathrm{ft}^{2}\left(\$ / \mathrm{m}^{2}\right)\end{array}$ \\
\hline $\begin{array}{c}\text { First Year } \\
\text { (from Utility } \\
\text { Bills) }\end{array}$ & $\begin{array}{c}47.5 \\
(539)\end{array}$ & $\begin{array}{c}1.6 \\
(18)\end{array}$ & $3 \%$ & $\begin{array}{c}45.9 \\
(521)\end{array}$ & $\begin{array}{c}148.1 \\
(1,682)\end{array}$ & $\begin{array}{c}1.21 \\
(13.02)\end{array}$ \\
\hline Second Year & $\begin{array}{c}30.6 \\
(348)\end{array}$ & $\begin{array}{c}14.9 \\
(169)\end{array}$ & $49 \%$ & $\begin{array}{c}15.7 \\
(178)\end{array}$ & $\begin{array}{c}50.6 \\
(575)\end{array}$ & $\begin{array}{c}1.17 \\
(12.59)\end{array}$ \\
\hline Third Year & 29.8 & 13.4 & $45 \%$ & $\begin{array}{c}16.4 \\
(186)\end{array}$ & $\begin{array}{c}53.0 \\
(602)\end{array}$ & $\begin{array}{c}0.85 \\
(9.15)\end{array}$ \\
\hline
\end{tabular}

1. PV production normalized by building floor area for comparison to site use intensity 


\subsection{Simulated Whole-building Performance}

Over the first three years of operation, the Lewis Center's energy performance has evolved from a site energy consumption intensity of $47.5 \mathrm{kBtu} / \mathrm{ft}^{2} \cdot \mathrm{yr}\left(539 \mathrm{MJ} / \mathrm{m}^{2} \cdot \mathrm{yr}\right)$ to the current $27.5 \mathrm{kBtu} / \mathrm{ft}^{2} \cdot \mathrm{yr}(312$ $\mathrm{MJ} / \mathrm{m}^{2} \cdot \mathrm{yr}$ ). With the long-term vision of operating as a net energy exporter, the crucial energy performance metrics are the site energy consumption and production. For the second year of operation for a typical year, the site consumption savings were $30 \%$ as compared to the energy code compliant base case. PV production met $41 \%$ of the building load. Other energy performance metrics that were applied to the Lewis Center were source energy savings and energy cost savings. For the second year of operation, the source energy savings were $58 \%$ as compared to the Base case. These savings were primarily due to the on-site PV system production. Due to high demand charges and no credit for exported PV production, no energy cost savings were realized for the first two years of operation. Even with a large PV system, the demand charges were generally not reduced. This was because peak demands occurred at times of no PV production. It is important to note that the design goal was to reduce energy, and not necessarily cost.

The site energy use intensity would have been $22.5 \mathrm{kBtu} / \mathrm{ft}^{2} \cdot \mathrm{yr}\left(256 \mathrm{MJ} / \mathrm{m}^{2} \cdot \mathrm{yr}\right)$ without the wastewater treatment space, with PV production meeting $76 \%$ of the load. For the third year of operation, this space was responsible for $24,881 \mathrm{kWh}(89,572 \mathrm{MJ} / \mathrm{yr})$, or $23 \%$ of the energy used at the Lewis Center for the Cleveland TMY2 weather data.

Based on the performance of the third year, the site energy savings were $48 \%$ for a typical weather year as compared to the Base Case. Fifty-nine percent of the building load would have been met by on-site PV production for typical weather. When source energy performance is considered, the building consumed $79 \%$ less than the Base case, at a source energy consumption intensity of $36.5 \mathrm{kBtu} / \mathrm{ft}^{2} \cdot \mathrm{yr}\left(415 \mathrm{MJ} / \mathrm{m}^{2} \cdot \mathrm{yr}\right)$. The current energy performance compares to or exceeds the documented performance of educational buildings in the CBECS database and the Oaks Hall high-performance building example. Although this is considered a low-energy building and one of the better performing academic buildings in the country, there is considerable room for improvement to help the building reach its vision of net-zero energy consumption. Based on optimized models incorporating recommend changes, NREL predicts the site energy savings could be increased to $64 \%$, with $85 \%$ of the building load met by PV.

The performance of the TMY2 Base Case, TMY2 As-built March 01-February 02, TMY2 As-built March 02-February 03, and the TMY2 optimized model are summarized in Figure 8-3 and Table 8-2. 


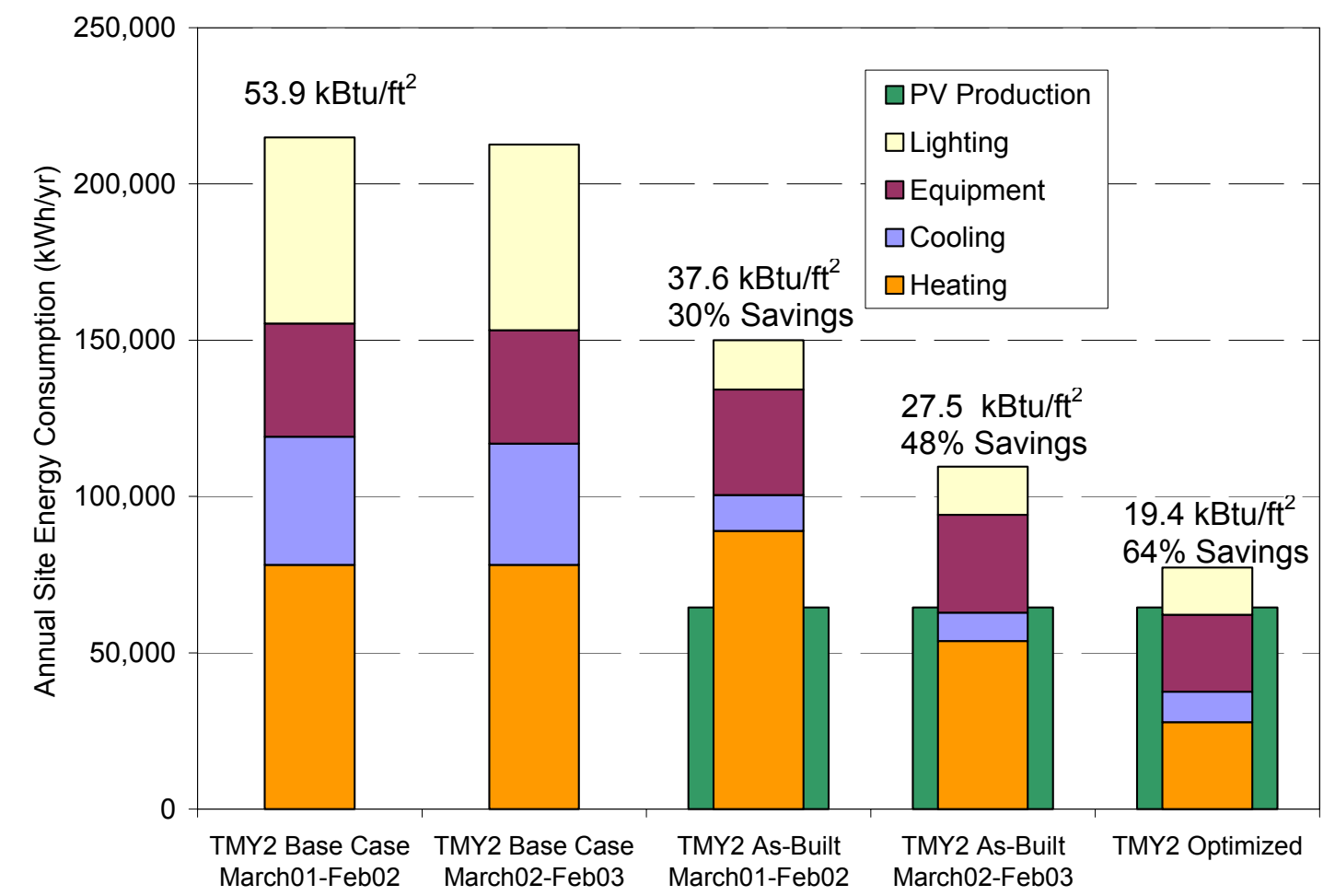

Figure 8-3 Annual performance for TMY2 2001-2002 Base-case model, as-built models, and optimized model

Table 8-2 Annual Energy Performance Summary for Each Building Version

\begin{tabular}{|c|c|c|c|c|c|}
\hline $\begin{array}{l}\text { Building } \\
\text { Version }\end{array}$ & $\begin{array}{c}\text { Site } \\
\text { Consumption } \\
\text { Energy } \\
\text { Intensity } \\
\mathrm{kBtu} / \mathrm{ft}^{2} \\
\left(\mathrm{MJ} / \mathrm{m}^{2}\right)\end{array}$ & $\begin{array}{l}\text { Percent Site } \\
\text { Savings as } \\
\text { Compared to } \\
\text { Base case }\end{array}$ & $\begin{array}{l}\text { Percent of } \\
\text { Building } \\
\text { Load Met by } \\
\text { PV }\end{array}$ & $\begin{array}{l}\text { Site Net Use } \\
\text { Energy } \\
\text { Intensity } \\
\mathrm{kBtu} / \mathrm{ft}^{2} \\
\left(\mathrm{MJ} / \mathrm{m}^{2}\right)\end{array}$ & $\begin{array}{c}\text { Source Net } \\
\text { Use Energy } \\
\text { Intensity } \\
\mathrm{kBtu} / \mathrm{ft}^{2} \\
\left(\mathrm{MJ} / \mathrm{m}^{2}\right)^{2}\end{array}$ \\
\hline $\begin{array}{l}\text { TMY2 Base case } \\
\text { with March 01- } \\
\text { February } 02 \\
\text { schedules }\end{array}$ & $\begin{array}{l}53.9 \\
(612)\end{array}$ & N.A & $0.0 \%$ & $\begin{array}{l}53.9 \\
(612)\end{array}$ & $\begin{array}{c}173.5 \\
(1,970)\end{array}$ \\
\hline $\begin{array}{l}\text { TMY2 Base case } \\
\text { with March 02- } \\
\text { February } 03 \\
\text { schedules }\end{array}$ & $\begin{array}{l}53.3 \\
(605)\end{array}$ & N.A & $0.0 \%$ & $\begin{array}{l}53.3 \\
(605)\end{array}$ & $\begin{array}{c}171.6 \\
(1.949)\end{array}$ \\
\hline $\begin{array}{l}\text { TMY2 As-built } \\
\text { March 01-Feb } 02\end{array}$ & $\begin{array}{c}37.6 \\
(427)\end{array}$ & $30.0 \%$ & $43.1 \%^{1}$ & $\begin{array}{l}21.4 \\
(243)\end{array}$ & $\begin{array}{r}68.9 \\
(782)\end{array}$ \\
\hline $\begin{array}{l}\text { TMY2 As-built } \\
\text { March 02-Feb } 03\end{array}$ & $\begin{array}{l}27.5 \\
(312)\end{array}$ & $48.0 \%$ & $59.0 \%^{1}$ & $\begin{array}{l}11.3 \\
(128)\end{array}$ & $\begin{array}{r}36.5 \\
(415)\end{array}$ \\
\hline TMY2 optimized & $\begin{array}{c}19.4 \\
(220)\end{array}$ & $63.6 \%$ & $84.5 \%^{1}$ & $\begin{array}{r}3.2 \\
(36)\end{array}$ & $\begin{array}{r}10.3 \\
(117)\end{array}$ \\
\hline
\end{tabular}

Notes:

${ }^{1}$ Calculated using typical PV performance without degradation with TMY2 weather data

${ }^{2}$ Calculated with $31 \%$ electricity conversion and delivery efficiency from source to site 


\subsection{PV System}

A full PV system evaluation conducted from March 1, 2001 through February 28, 2002 considered all the main system components. NREL validated the efficiency of the DC-to-AC PV power conversion and compared it to expected efficiencies, verified the operation of the MPPT of the inverters, and identified and quantified multiple sources of performance degradation. The PV system performance was degraded $5 \%$ of the total operational hours. The measured average generation efficiencies were verified using the manufacturer's ratings. Over the upper range of operating conditions, the generation efficiency was typically between $9-12 \%$.

In the second year of operation, the PV system exported 28,879 $\mathrm{kWh}(103,960 \mathrm{MJ})$, or $49 \%$ of the total production, to the grid without financial credit. A net-metering agreement was implemented in April of 2002 so that now the Lewis Center gets credit for exporting excess electricity to the grid. The PV production does reduce energy consumption charges; however, the electricity demand costs in this allelectric building are not typically reduced. It is difficult to cost-justify the PV system solely on energy cost reductions. A large potential for reducing peak demands and demand charges with the PV system does exist in the case of the Lewis Center's $60-\mathrm{kW}$ PV system. This would require demand responsive controls that limit electrical loads during periods of minimal PV production (clouds or at night). Additional demand reduction cost savings due to the PV system would increase the cost-justification of the PV system.

Table 8-3 summarizes the total PV production lost because of PV system faults (identified and unidentified causes) and irregular operations.

Table 8-3 Performance Degradation Results

\begin{tabular}{|l|c|c|}
\hline \multicolumn{1}{|c|}{ Type of Fault } & $\begin{array}{c}\text { Estimated PV } \\
\text { Production Lost (kWh) }\end{array}$ & $\begin{array}{c}\text { Percent of Total PV } \\
\text { Production }\end{array}$ \\
\hline \hline Transformer standby losses & $4,363.5$ & 7.3 \\
\hline Inverter faults (identified and unidentified causes) & 707.9 & 1.2 \\
\hline Snow & 769.0 & 1.3 \\
\hline Operations and maintenance & 879.4 & 1.5 \\
\hline
\end{tabular}

Performance degradations were identified through the minimum conversion efficiency procedure and quantified by calculating estimated losses. The resulting operations and maintenance and inverter faults were determined, along with expected annual performance without typical degradation losses. Because energy losses due to snow are typical, they were included in the calculation of expected annual performance. The inverter shutdown at full power due to $\mathrm{AC}$ voltage faults has been addressed and the related degradations are not expected during typical operation.

The typical annual PV production was predicted to be $64,500 \mathrm{kWh}(232,200 \mathrm{MJ})$, or $16.2 \mathrm{kBtu} / \mathrm{ft}^{2} \cdot \mathrm{yr}$ $\left(184 \mathrm{MJ} / \mathrm{m}^{2} \cdot \mathrm{yr}\right)$ normalized for building square footage. For the summer months when PV generation was the highest and the consumption the lowest, the building, on average, exported electricity from 8 a.m. to 6 p.m. From the utility perspective, the building was a net positive during daylight hours in the summertime and provided power when it is most needed by the grid. The typical annual PV production is still less than the best-case energy consumption of $19.4 \mathrm{kBtu} / \mathrm{ft}^{2} \cdot \mathrm{yr}\left(220 \mathrm{MJ} / \mathrm{m}^{2} \cdot \mathrm{yr}\right)$. Additional PV capacity is needed, combined with energy consumption reduction and efficiency upgrades, to realize the net-zero energy vision of the Lewis Center. Using the current PV technology, an additional 30-kW PV system would increase annual PV production (normalized by building area) from $16.2 \mathrm{kBtu} / \mathrm{ft}^{2} \cdot \mathrm{yr}(184$ $\left.\mathrm{MJ} / \mathrm{m}^{2} \cdot \mathrm{yr}\right)$ to $24.3 \mathrm{kBtu} / \mathrm{ft}^{2} \cdot \mathrm{yr}\left(276 \mathrm{MJ} / \mathrm{m}^{2} \cdot \mathrm{yr}\right)$. The size requirements for this type of PV system would extend beyond the footprint of the building. 


\subsection{Lighting and Daylighting}

The analysis of the energy consumption of the installed lighting revealed that the lighting systems were operating at a high level of performance. This conclusion was evident in the low lighting energy intensity of $1.9 \mathrm{kBtu} / \mathrm{ft}^{2} \cdot \mathrm{yr}\left(22 \mathrm{MJ} / \mathrm{m}^{2} \cdot \mathrm{yr}\right)$. Much of the savings is attributed to lighting design and daylighting. In comparison, according to the 1999 CBECS database, the average site energy lighting intensity for all educational buildings was $15.8 \mathrm{kBtu} / \mathrm{ft}^{2} \cdot \mathrm{yr}\left(179 \mathrm{MJ} / \mathrm{m}^{2} \cdot \mathrm{yr}\right)$.

Compared to the simulated lighting performance of the conventional Base-case model, the Lewis Center lighting consumed $72 \%$ less electricity. These savings were attributed to good lighting and daylighting design and operation, as the Lewis Center incorporated a reduced LPD, along with daylighting design strategies with occupancy controls. Also important to these lighting consumption savings was the appropriate manual operation of the lighting zones.

By assessing the daylighting design for specific zones, the team determined that the offices and the second-floor corridor have the potential to be completely daylit for $83 \%$ of the daytime hours over the year. The daylighting potential in the second-floor classroom varies by season because glare control and daylighting penetration are dependent on solar altitude angles. During a month at the summer solstice, the classrooms could potentially be completely daylit for $73 \%$ of the daytime hours. For a month at the winter solstice, the classrooms could potentially be completely daylit for $58 \%$ of the daytime hours. For a month at the spring or fall equinox, the classrooms could potentially be completely daylit for $52 \%$ of the daytime hours. The auditorium zone suffered from a lack of daylighting, and the resulting increased lighting energy use.

To realize the classroom, corridor, atrium, and office daylighting potential, appropriate automated and manual control of the electrical lighting was necessary. A review of the lighting control strategies in the various lighting zones revealed several opportunities for improved control. In the classrooms and corridors, the occupancy sensors were rewired for a daylighting hold so that the electric lights did not automatically turn on if there was enough daylighting. The manual dimming control in the atrium and auditorium was generally managed appropriately, although periods of mismanagement were identified. Occupancy sensors in these zones should be used to automatically turn off these lights. Continuously dimming daylighting controls would be the optimal control solution.

In general, the installed lighting at the lower LPD can provide adequate desktop illuminance levels in the classrooms. The indirect-direct light fixtures worked well for low ceilings, providing a bright ceiling and direct light to the work plane, which created bright spaces (first floor classrooms). They did not work as well in areas with high dark ceilings (second floor classrooms). Because vertical illuminance at the whiteboard in the second-floor classrooms is lower than the recommended illuminance levels, additional task lighting for this surface should have been part of the daylighting design. Additional illumination on this surface may also reduce the need for the lighting in the remainder of the space. Lighting in the classrooms could also be enhanced by separating out the view glass from the daylighting glass. Top down/bottom up blinds can be provided on the view glass for glare control while diffusing or redirecting glass can be used on upper part of the fenestration.

Parking lot and sidewalk lighting use was the largest single lighting end use at the Lewis Center. Exterior lighting controls or scheduling that reduces the operation of these lights would significantly reduce overall lighting energy use.

As other building energy consumption in the Lewis Center is reduced and optimized, lighting energy consumption will become a greater percent of the building load. In turn, the necessity for maximizing the daylighting potential and exercising proper control of the lighting systems becomes equally important. 


\subsection{Lessons Learned}

The lessons learned from this study fall in three major categories: design process issues, technology issues, and lessons related to the evaluation process of the building.

The strong goals set by the owner early in the design process were key to driving the project. Even though the long-term vision of producing a building that is a net exporter of electrical energy has yet to be met, the building has made substantial strides on the path towards zero-energy buildings. An important objective of the design process was to carefully integrate the work of the engineer, energy consultant, and architect to make sure they were all working toward a common goal. The design process was not explicitly examined as part of this report; however, specific mistakes acknowledged by the design and owner team, were made in the integrated design approach. [Further discussion of the Lewis Center design process is included in Malin (2002), Orr (2002), and Scofield (2002).]

The following low-energy building technology-related lessons were identified:

- A high-performance academic building is possible in a heating dominated climate such as northern Ohio. Unlike current typical building practice, the building is heating dominated. This is contrary to the trend of cooling dominated buildings in traditionally heating dominated climates. A zero-energy building in this climate will be very difficult to realize, especially with on-site wastewater treatment. Additional PV capacity, extending beyond the footprint of the building, and optimal performance are required to meet the zero-energy vision.

- PV systems must be engineered to minimize transformer and balance of system losses. These losses can represent a significant portion of the overall system production.

- PV systems may not significantly reduce the building demand. In this case, any small demand reduction due to PV is from load diversity.

- During the summer months, on average, large PV systems in commercial buildings can export electricity from 8 a.m. to 6 p.m. From the utility perspective, the building was a net positive during daylight hours in the summertime and provided power when it is most needed by the grid.

- Control design must be fully integrated with the full capabilities of the equipment in the building including $\mathrm{CO}_{2}$ sensors, motion sensors, and thermostats. A balance must be achieved between the human operators and the automation.

- Dark ceilings must be avoided to fully take advantage of the daylighting and uplighting.

- Daylighting sensors are needed in all daylit areas. It is not sufficient to rely on manual controls.

- Daylighting must be designed into all occupied spaces. The daylighting design should consider additional heating and cooling loads imposed on the building. Areas such as the auditorium suffered from lack of daylighting design and consequently additional energy consumption. Overglazed areas such as the atrium provided abundant daylighting and lighting savings, but resulted in additional heating and cooling loads.

- Specifications for heat pumps must work with appropriate ground water temperatures.

- Electric boilers can be used as a back-up source, if they are used sparingly and do not cause excessive demand charges on the building. Controls and staging are essential for integration of limited use systems, such as these.

The lessons learned from the evaluation of the Lewis Center include:

- A complete high-performance building should result in significant energy savings in the following metrics: site energy savings, source energy savings, and energy cost savings. A building can excel in the energy performance indices most important to the building owners, but 
fall short or exaggerate other performance indices. The Lewis Center performed well in site savings, realized minimal energy cost savings, and excelled in source savings (mostly due to PV production and benchmarking techniques). A building energy performance evaluation should focus on the metric the building was designed to optimize, but it should also consider other significant performance indicators.

- A complete energy balance on metering is essential to find faults in monitoring. A dedicated DAS for monitoring energy performance can provide $99 \%$ data availability over a 2 year monitoring period. Missing data can be minimized with error checking routines and reasonable data filling techniques. Fifteen-minute data logging is appropriate for a wide-range of evaluations. In cases where equipment issues were found (such as the PV inverter cut-out), data sets that are more detailed were collected for limited periods.

- The IEA/SHC Task 21 lighting protocol needs to be reevaluated. Much data was recorded, but not used in the evaluation process.

- Detailed monitoring is needed to fully evaluate the building and to identify additional areas of energy savings, a level of monitoring beyond the scope of typical commissioning projects. With this level of analysis, the building energy load was cut in half compared to the building at the end of the detail monitoring and evaluation process. Continuous monitoring at a minute time step interval was also valuable for detecting PV inverter faults. Without monitoring, PV system downtimes may have been much longer.

- To calculate energy savings of a building, a model must be calibrated against actual building data. Too many changes occurred to use the design-based models as accurate predictors of energy consumption. Schedules and plug loads vary widely from original assumptions. The Base-case model must also be modified to reflect the as-built schedules and plug loads. A whole-building evaluation should consist of a combination of monitored energy use data and hourly building simulations. A calibrated as-built simulation compared to a conventional base case can provide a confident prediction of annual site, source, and cost savings. Using typical meteorological year weather data allows long-term savings calculations with relatively short-term data. A corollary of this is that models used for design should be carefully reviewed to ensure that current practice for plug loads and schedules are used, as they will impact design decisions.

- A whole-building simulation tool is needed that can adequately model sub-hourly energy use, site utility costs, and on-site production. We were not able to model the as-built energy costs of the Lewis Center due to the limitations of the DOE-2 simulation program. With a simulation tool that could model energy use, PV production, and peak demand on a 15-min time step, we could research and develop demand responsive controls that enable on-site PV production to reduce peak demand and optimize energy costs.

In general, the mechanical design of the electric boiler hydronic system did not meet the design intent of the rest of the building. This design flaw, combined with original inadequate advanced controls, resulted in the initial limited energy savings. Through a detailed energy performance evaluation, continuous commissioning, and occupant dedication to continually improve the Lewis Center's energy performance, the energy savings have substantially improved. The Lewis Center is now one of the better energy performing academic buildings in the country. The evaluation shows that an academic building in a heating dominated climate can operate as a low energy building, and may be able to approach a net-zero energy building in the near future. Further work is needed to improve the energy cost savings, as the PV system did not significantly reduce demand charges. Continued improvements and monitoring, combined with advanced controls understanding and implementation, will ensure the Lewis Center operates at its full potential. 


\subsection{Future Research}

As with any research project, future research topics are possible, as indicated below.

- Identify the contribution of each high-performance feature to the overall building savings. A reverse parametric simulation analysis would identify the technologies that work the best in this environment. Additional what-if simulation scenarios could also be performed to evaluate the passive solar design of the Lewis Center. Optimal atrium design in a heating dominated climate could be determined based on these simulations.

- Continuous monitoring of building energy performance is essential to the long-term vision of operating the building as a net energy exporter. Identify areas of degrading performance with time.

- Study the impacts of advanced controls on the building including better control of outside air based on $\mathrm{CO}_{2}$ sensors and the affect on air quality.

- Investigate issues related to large-scale PV systems on small electrical buses to prevent overvoltage situations. Study I-V curves for a broader range of operating conditions to fully characterize large-scale PV systems in the built environment to enhance compatibility with electrical systems and improve efficiency. This study includes array configuration issues.

- Develop peak demand algorithms for minimizing electrical cost to fully benefit from energy efficiency devices (especially the daylighting) and the on-site generation capacity, including modeling the building and the PV system with a 15-min time step in an integrated building simulation program. Study the ability for PV systems to minimize demand with controls.

- Examine the long-term performance of the wells in the ground source heat pump loop. The capacity of the wells to reject and accept heat from the ground becomes important with the addition of water heating heat pumps to the ground loop.

- Update the IEA/SHC Task 21 daylighting protocol based on experiences with collecting daylighting in this project. 


\section{References}

Anacon Systems 2003. Single-Phase Variable Speed Fan Motor Controller. http://www.anaconsystems.com/ Last accessed October 29, 2004.

ARI 2003a. ARI Standard 320. http://www.ari.org/std/standards.html. Last accessed October 29, 2004. American Refrigeration Institute, Virginia.

ARI 2003b. ARI Standard 330. http://www.ari.org/std/standards.html. Last accessed October 29, 2004. American Refrigeration Institute, Virginia.

ASHRAE 1991. ANSI/ASHRAE Standard 84-1991: Method of Testing Air-to-Air Heat Exchangers. Atlanta, GA: ASHRAE.

ASHRAE 2001a. ANSI/ASHRAE/IESNA Standard 90.1-2001: Energy Standard for Buildings Except Low-Rise Residential Buildings. Atlanta, GA: ASHRAE.

ASHRAE, 2001b. Handbook of Fundamentals. Atlanta, GA: ASHRAE.

Atif, M.R.; Love, J.; Littlefair, P. 1997. Daylighting Monitoring Protocols and Procedures for Buildings. A report of IEA Task 21/Annex 29 Daylight in Buildings. International Energy Association, Paris, France.

BP 2003. British Petroleum 585F PV Module Specification Sheet.

http://www.bpsolar.com/ContentDocuments/84/BP\%20585U.pdf. Last accessed October 29, 2004. BP

Solar, Frederick, MD,

Brix, H. 1999. "How 'Green' Are Aquaculture, Constructed Wetlands, and Conventional Wastewater Treatment Systems?” Water Science Technology, Vol. 40, No. 3, 1999; pp. 45-50.

Carrier 2003. Carrier Aquazone. "50HQ, 50VQ Large Capacity Water Source Heat Pumps." Data Sheet. http://www.xpedio.carrier.com/idc/groups/public/documents/techlit/50h,v-8pd.pdf. Last accessed October 29, 2004.

Continental Controls Systems 2003. http://www.ccontrolsys.com/products/pulse output.html. Last accessed October 29, 2004.

DOE 2003. 2003 Buildings Energy Databook. U.S. Department of Energy. http://buildingsdatabook.eren.doe.gov/. Pg. 1-1, Table 1.1.3. Last accessed October 29, 2004.

EIA 1998. Energy Information Administration. A Look at Commercial Buildings in 1995:

Characteristics, Energy Consumption and Expenditures. DOE/EIA-0625(95). Washington, DC: EIA.

EIA 1999. Energy Information Administration. 1999 Commercial Buildings Energy Consumption Survey. Washington, DC: EIA. http://www.eia.doe.gov/emeu/cbecs Last accessed October 29, 2004.

EIA. 2000. Annual Energy Review. DOE/EIA-384(00) page 217, diagram 5. Washington, DC: EIA.

EIA. 2001. "State Electricity Profiles." Washington, DC: EIA.

http://www.eia.doe.gov/cneaf/electricity/st_profiles/ohio.pdf Last accessed October 29, 2004.

EnergyPlus 2003. EnergyPlus User's Manual, V1.1.0; April 2003. Engineering Document. Washington, DC: U.S. Department of Energy. http://www.energyplus.gov/. Last accessed October 29, 2004.

Energy Simulation Specialists, Inc. 1995. DOE-2.1E Energy Simulation Seminar Workbook. Tempe, AZ: Energy Simulation Specialists, 1995. 
Greenheck 2003. Energy Recovery Application Manual.

http://www.greenheck.com/pdf/energy/ERV_app_manual.pdf. Last accessed October 29, 2004.

Greenheck, Schofield, Wisconsin.

Griffith, B.; Deru, M.; Torcellini, P.. 2004. "Monitoring and Analysis of the Energy Performance of the Chesapeake Bay Foundation's Philip Merrill Environmental Center." NREL/TP 550-34830. Golden, CO: National Renewable Energy Laboratory.

Hay, J.E.; Davies, J.A 1978. "Calculation of the Solar Radiation Incident on an Inclined Surface.” Proceedings, First Canadian Solar Radiation Data Workshop, J. E. Hay and T. K. Won, eds. Canada Supply and Services, Ottawa, Canada, 1978.

IESNA 2000. Illuminating Engineering Society of North America. A Lighting Handbook-Reference and Application Volume. New York: IESNA.

King, D.L.; Kratochvil, J.A.; Boyson, W.E.; Bower, W.I. 1998. "Field Experience with a New Performance Characterization Procedure for Photovoltaic Arrays." Presented at the 2nd World Conference and Exhibition on Photovoltaic Solar Energy Conversion, Vienna, Austria, July 1998. Sandia National Laboratories, Albuquerque, NM.

Malin, N.; Boehland, J. 2002 "Projects: Oberlin College's Lewis Center," Environmental Building News. Vol. 11, No. 7/8, July/August 2002. Brattleboro, VT: Building Green.

Mermoud, A. 1996. PVSYST Version 3.2. User's Manual. Geneva: University of Geneva, University Center for the Study of Energy Problems. Available online at http://www.pvsyst.com/. Last accessed October 29, 2004.

NREL 2004. "High-performance Buildings Research," NREL High-performance Buildings website. http://www.nrel.gov/buildings/highperformance/oberlin.html. Last accessed October 29, 2004.

NREL, 1995. User's Manual for TMY2s (Typical Meteorological Years), NREL/SP-463-7668, and TMY2s, Typical Meteorological Years Derived from the 1961-1990 National Solar Radiation Data Base, National Renewable Energy Laboratory June 1995, CD-ROM. Golden, Colorado: http://rredc.nrel.gov/solar/old data/nsrdb/tmy2. Last accessed October 29, 2004.

Oberlin College Adam Joseph Lewis Center for Environmental Studies, 2003. Lewis Center homepage. http://www.oberlin.edu/ajlc/ajlcHome.html. Last accessed October 29, 2004.

Oberlin College News Services, 2002. "Environmental Studies Building Dedication Update, September 2000." http://www.oberlin.edu/newserv/stories/esc symposium.html. Last accessed October 29, 2004.

Orr, D. 2002. "The Nature of Design.” New York: Oxford University Press.

Pasqualetto, L.; Zmeureantu, R.; Fazio, P. 1997. "A Case Study of Validation of an Energy Analysis Program: MICRO-DOE-2.1E.” Building and Environment, Vol. 33, No. 1, June 1997; pp. 21-41.

Perez, R.; Ineichen, P.; Seals, R.; Michalsky, J.; Stewart, R.1990. "Modeling Daylight Availability and Irradiance Components from Direct and Global Irradiance.” Solar Energy, Vol. 44, No. 5, 1990; pp. 271289

RMI, 2001. “Oberlin: Climate Neutral by 2020.” Rocky Mountain Institute: Snowmass, CO.

Scofield, J.H.2002. "Early Performance of a Green Academic Building." ASHRAE Transactions 2002, Vol. 108, Part 2, Pg. 1214-1230. Atlanta, GA: ASHRAE

Scofield, J.H., Kaufman, D., 2002. "First year performance of the roof-mounted, 45-kW PV array on Oberlin College's Adam Joseph Lewis Center." Proc of the $29^{\text {th }}$ IEEE Photovoltaic Specialists Conference, May 20-24, 2002. New Orleans (IEEE, New York, 2002), Pg. 1691-1694. 
Shonder, J.A.; Martin, M.A.; Hughes, P.J.; Thornton, J. 2000. Geothermal Heat Pumps in K-12 Schools, A Case Study of the Lincoln, Nebraska, Schools, ORNL/TM-2000/80. Oak Ridge, TN: Oak Ridge National Laboratory.

Square-D 2003. Energy-Efficient Isolation Transformer, Low Voltage General Purpose Dry Type. http://www.squared.com/us/products/transfor.nsf/07a0210021262d45862564b5006e4f84/73d4619a869b3 b80852566bf0058900d/\$FILE/7435CT9901.pdf. Last accessed October 29, 2004.

Vermont Law School 2002. "James L. and Evelena S. Oakes Hall, Vermont Law School's AwardWinning Classroom Building." Vermont Law School Office of Media Relations online. http://www.vermontlaw.edu/life/lifabooak.cfm. Last accessed October 29, 2004.

Xantrex 2003. Operation Manual for PV-15208 Grid-Tied PV Inverter. http://www.xantrex.com/web/id/11/p/docs/pt/23/product.asp Last accessed October 29, 2004.

York, A.; Tucker, F.; et al. 1980 DOE-2 Reference Manual 2.1, Part 1. May 1980. Los Alamos, NM: Los Alamos National Laboratory. 


\section{Appendix A: Design Goals and Objectives}

The following design goals and objectives were developed by the Oberlin College Environmental Studies Programming Committee in December 1995:

- Process: optimize student, faculty, and community participation in the design and subsequent use of the building

- Pedagogy: encourage mindfulness of materials and energy; promote ecological competence and instruct in the practical arts of inhabitation engineering, materials use, building management, waste recycling, gardening, and horticulture as well as the development of analytical skills such as least cost and end use analysis and life-cycle costing for materials, water, and energy as well as integrated resource planning

- Materials: extracted, harvested, manufactured, and installed or simply reused without compromising justice, human dignity, and environmental quality - emphasizing those that are nontoxic and/or recycled, sustainably managed, and, when possible, locally available

- Energy: maximize energy efficiency while meeting as much of the energy needs for heating, cooling, lighting and electrical power from renewable sources as possible, aiming to be a net energy exporter not an energy importer

- Water: maximize efficiency in water use while recycling all organic wastes from the building using advanced techniques of ecological engineering

- Landscape: enhance biological diversity using rare and endangered indigenous plants; use trees and vegetation to moderate temperatures and intensive gardens to supply vegetable and fruits and teach horticulture

- Economics: account for the full cost of all materials, labor resources, technologies, and systems of technologies used in the structure or required by its upkeep, including:

- ecological and social costs incurred in mining, harvest, manufacture, and transportation of all materials

- $\mathrm{CO}_{2}$ costs of construction and maintenance

- all deferred costs imposed on future generations and ways to offset such costs.

The following additional guidelines were added in 1996:

- The "project" will incorporate the building and landscape together.

- The building and landscape systems will work with natural energy systems.

- The building systems will be "rendered visible."

- Indoor air quality will be optimized.

- Daylighting will be provided for all spaces.

- Materials will come from local resources (to the highest possible degree).

- Building components will be "state of the shelf."

- The building design will anticipate future technologies.

- The building will be designed as housing for the future.

- The building design will be flexible, allowing for the growth and development of the Environmental Studies Program.

- The project will strive to be a net energy exporter.

- The project will provide orientation to the natural world.

- The building and the landscape will be integrated.

- The building will blur the distinction between "inside" and "outside" spaces.

- The landscape will teach and communicate about the site and the region. 
- The maintenance and management of the landscape will be participatory.

- The landscape design will incorporate a small-scale garden for food production.

- The landscape design will be a microcosm of the regional ecosystem.

- The landscape design will be a seed for the future development of the campus and region.

- The living system will be used for treating wastes.

- The building will help address the consideration that "knowing where you are is important to knowing who you are."

- The project will be a powerful, memorable statement on the art and ecology of design. 


\section{Appendix B: Classroom Assignments in the Adam Joseph Lewis Center, Fall}

2002

\begin{tabular}{|c|c|c|}
\hline Room & Days/Time & Class/Instructor \\
\hline \multirow[t]{3}{*}{120 Auditorium, seats 100} & TTh: 11:00 a.m.-12:15 p.m. & ENVS 101/Petersen \\
\hline & MWF: 11:00-11:50 a.m. & HIST 106/Kelley \\
\hline & TTh: 1:30-2:45 p.m. & ENVS 101/Macauley \\
\hline \multirow[t]{5}{*}{ Workspace 3 , seats 36} & TTh: 9:35-10:50 a.m. & ENGL 344/Willman \\
\hline & MWF: 11:00-11:50 a.m. & Soci 266/Weston \\
\hline & TTh: 1:30-4:30 p.m. & EMAR 204/Weintraub \\
\hline & MWF: 2:30-3:20 p.m. & ENGL 302/Bryan \\
\hline & MWF: 3:30-4:20 p.m. & ENGL 336/Newstrom \\
\hline \multirow[t]{6}{*}{ Workspace 2 , seats 18} & W: 7:30-9:30 p.m. & ENVS 491/Wolfe-Cragin \\
\hline & W: 2:30-4:20 p.m. & HIST 338/Stroud \\
\hline & Th: 1:00-2:50 p.m. & ECON 423/Grim \\
\hline & W: 3:30-4:20 p.m. & HIST 160 disc/DiCenzo \\
\hline & Th: 10:00-10:50 a.m. & HIST 160 disc/DiCenzo \\
\hline & TF: 8:00-9:00 a.m. & EXCO/Dr. Truhaft \\
\hline \multirow[t]{5}{*}{ Workspace 1 , seats 36} & TTh: 1:30-2:45 p.m. & HIST/JWST 234/Magnus \\
\hline & TTh: 3:00-4:15 p.m. & ENVS 208/Macauley \\
\hline & M: 7:15-9:45 p.m. & ENVS 335/Macauley \\
\hline & MWF: 3:30-4:20 p.m. & ENGL 336/Newstrom \\
\hline & W: 8-10 p.m. & $\begin{array}{l}\text { EXCO/Eden Trenor \& John } \\
\text { Millet }\end{array}$ \\
\hline \multirow[t]{5}{*}{204 Conference, seats 15} & $\begin{array}{l}\text { Monday-Friday } \\
\text { 8:00-9:00 a.m. } \\
\text { 12:00-1:30 p.m. }\end{array}$ & ENVS meetings \\
\hline & MW: 2:30-4:20 p.m. & CRWR 201/Alexander \\
\hline & M: 7:15-9:15 p.m. & CRWR 490/Alexander \\
\hline & T: 7:15-10:00 p.m. & CRWR 201/Alexander \\
\hline & Th: 7:00-10:00 p.m. & CRWR 340/Bucak \\
\hline
\end{tabular}


Appendix C: Building Performance Summary Data

Building Performance Summary, March 1, 2001 through February 28, 2002

\begin{tabular}{|c|c|c|c|c|c|c|c|c|c|c|c|c|c|}
\hline & Mar-01 & Apr-01 & May-01 & June-01 & July-01 & Aug-01 & Sept-01 & Oct-01 & Nov-01 & Dec-01 & Jan-02 & Feb-02 & $\begin{array}{r}\text { Annual } \\
\text { Totals }\end{array}$ \\
\hline $\begin{array}{l}\text { Total Building Consumption } \\
\text { (KWh) }\end{array}$ & 25,878 & 10,060 & 8,174 & 4,820 & 7,740 & 7,509 & 7,270 & 7,530 & 8,232 & 9,782 & 11,969 & 13,175 & 122,139 \\
\hline Total PV Production (KWh) & 4,535 & 6,396 & 5,798 & 7,481 & 8,283 & 6,653 & 5,852 & 4,167 & 2,918 & 2,093 & 2,273 & 3,078 & 59,519 \\
\hline Net Building Use (KWh) & 21,344 & 3,664 & 2,376 & $-2,661$ & -543 & 856 & 1,419 & 3,369 & 5,314 & 7,689 & 9,696 & 10,098 & 62,621 \\
\hline Total HVAC & 20,635 & 5,339 & 3,277 & 773 & 3,943 & 3,622 & 3,308 & 3,446 & 3,958 & 5,775 & 8,080 & 9,243 & 71,397 \\
\hline EB1 & 14,489 & 2,757 & 197 & 41 & 1 & 2 & 862 & 462 & 549 & 1,080 & 3,132 & 4,489 & 28,063 \\
\hline EB2 & & & 0 & 0 & & 0 & 0 & 0 & 0 & & 0 & 0 & 0 \\
\hline $\mathrm{HP} 4$ & 455 & 578 & 861 & 29 & 1,267 & 579 & 494 & 1,229 & 1,754 & 2,692 & 2,544 & 2,433 & 14,913 \\
\hline HP5 & 2,523 & 726 & 734 & 54 & 1,450 & 1,996 & 904 & 639 & 423 & 266 & 451 & 727 & 10,892 \\
\hline ERV-1 & 158 & 83 & 485 & 1 & 286 & 72 & 91 & 128 & 276 & 444 & 290 & 333 & 2,646 \\
\hline ERV-2 & 963 & 390 & 442 & 7 & 300 & 449 & 356 & 373 & 323 & 152 & 85 & 172 & 4,012 \\
\hline Room heat Pumps & 800 & 338 & 255 & 440 & 357 & 281 & 334 & 355 & 388 & 862 & 1,225 & 860 & 6,496 \\
\hline VSD Ground Pumps & 207 & 310 & 297 & 200 & 281 & 244 & 213 & 248 & 222 & 252 & 227 & 205 & 2,907 \\
\hline Circulation Pumps & 1,040 & 156 & 6 & 1 & 0 & 0 & 54 & 12 & 23 & 28 & 126 & 24 & 1,469 \\
\hline Total Lights & 1,642 & 1,564 & 1,386 & 990 & 900 & 1,008 & 1,208 & 1,374 & 1,650 & 1,552 & 1,340 & 1,479 & 16,093 \\
\hline Indoor Room Lights & 422 & 384 & 326 & 161 & 121 & 166 & 255 & 316 & 400 & 317 & 177 & 368 & 3,413 \\
\hline Auditorium Lights & 151 & 216 & 181 & 81 & 74 & 83 & 150 & 128 & 151 & 75 & 58 & 140 & 1,487 \\
\hline Emergency Lights & 310 & 309 & 277 & 204 & 155 & 169 & 181 & 206 & 232 & 223 & 190 & 212 & 2,668 \\
\hline Side Walk Lights & 475 & 408 & 375 & 339 & 334 & 359 & 392 & 456 & 547 & 591 & 577 & 480 & 5,334 \\
\hline Parking Lot Lights & 285 & 247 & 226 & 204 & 215 & 231 & 230 & 268 & 320 & 346 & 338 & 280 & 3,191 \\
\hline Total Equipment & 3,601 & 3,157 & 3,511 & 3,057 & 2,897 & 2,879 & 2,754 & 2,711 & 2,624 & 2,456 & 2,550 & 2,453 & 34,649 \\
\hline Receptacles & 1,546 & 1,243 & 1,258 & 1,045 & 833 & 884 & 695 & 616 & 551 & 501 & 571 & 595 & 10,337 \\
\hline Emergency Receptacles & 420 & 412 & 424 & 409 & 369 & 334 & 324 & 339 & 323 & 340 & 339 & 303 & 4,333 \\
\hline PV system Consumption & 377 & 318 & 347 & 260 & 287 & 320 & 344 & 399 & 406 & 457 & 470 & 377 & 4,364 \\
\hline Elevator & 206 & 181 & 168 & 171 & 166 & 167 & 176 & 189 & 183 & 203 & 216 & 198 & 2,223 \\
\hline $\mathrm{DHW}$ & 107 & 82 & 114 & 61 & 30 & 64 & 65 & 78 & 99 & 89 & 76 & 89 & 955 \\
\hline $\begin{array}{r}\text { Wastewater treatment } \\
\text { Miscellaneous Equipment }\end{array}$ & 945 & 922 & 1,199 & 1,111 & 1,213 & 1,111 & 1,150 & 1,090 & 1,061 & 867 & 878 & 892 & 12,438 \\
\hline
\end{tabular}


Building Performance Summary, March 1, 2002 through February 28, 2003

\begin{tabular}{|c|c|c|c|c|c|c|c|c|c|c|c|c|c|}
\hline & Mar-02 & Apr-02 & May-02 & June-02 & July-02 & Aug-02 & Sept-02 & Oct-02 & Nov-02 & Dec-02 & Jan-03 & Feb-03 & $\begin{array}{r}\text { Annual } \\
\text { Totals }\end{array}$ \\
\hline $\begin{array}{l}\begin{array}{l}\text { Total Building Consumption } \\
\text { (KWh) }\end{array} \\
\end{array}$ & 13,309 & 7,805 & 6,605 & 5,571 & 5,418 & 5,979 & 6,652 & 8,297 & 11,434 & 14,823 & 17,660 & 15,426 & 118,979 \\
\hline Total PV Production (KWh) & 3,688 & 5,026 & 6,604 & 7,584 & 7,949 & 6,988 & 5,979 & 3,653 & 1,579 & 1,172 & 1,398 & 1,921 & 53,540 \\
\hline Net Building Use (KWh) & 9,620 & 2,779 & 1 & $-2,013$ & $-2,531$ & $-1,009$ & 673 & 4,644 & 9,855 & 13,652 & 16,262 & 13,506 & 65,439 \\
\hline Total HVAC & 9,076 & 3,789 & 2,639 & 1,697 & 1,818 & 2,129 & 2,245 & 3,538 & 6,884 & 10,169 & 13,487 & 11,404 & 68,875 \\
\hline EB1/HP-6 and HP-7 & 3,518 & 626 & 293 & 5 & 1 & 1 & 2 & 151 & 1,175 & 4,212 & 5,284 & 4,647 & 19,915 \\
\hline EB2 & & 32 & 0 & 0 & 0 & 0 & 0 & 0 & 10 & 0 & 0 & 0 & 42 \\
\hline HP4 & 3,163 & 784 & 245 & 519 & 681 & 928 & 782 & 1,501 & 2,174 & 2,406 & 3,673 & 2,147 & 19,002 \\
\hline HP5 & 516 & 515 & 783 & 86 & 113 & 118 & 228 & 460 & 812 & 736 & 195 & 421 & 4,982 \\
\hline ERV-1 & 482 & 167 & 84 & 151 & 92 & 116 & 197 & 197 & 496 & 523 & 636 & 436 & 3,577 \\
\hline ERV-2 & 146 & 188 & 406 & 30 & 68 & 89 & 239 & 259 & 251 & 171 & 241 & 151 & 2,239 \\
\hline Room heat Pumps & 948 & 750 & 357 & 728 & 686 & 684 & 564 & 601 & 678 & 1,547 & 1,599 & 2,652 & 11,794 \\
\hline VSD Ground Pumps & 248 & 255 & 190 & 177 & 177 & 193 & 226 & 371 & 344 & 462 & 708 & 797 & 4,147 \\
\hline Circulation Pumps & 55 & 473 & 281 & 2 & 0 & 0 & 6 & 0 & 946 & 111 & 1,150 & 154 & 3,177 \\
\hline Total Lights & 1,487 & 1,478 & 1,311 & 953 & 987 & 1,146 & 1,369 & 1,636 & 1,729 & 1,712 & 1,284 & 1,368 & 16,460 \\
\hline Indoor Room Lights & 323 & 364 & 294 & 149 & 150 & 151 & 257 & 405 & 429 & 433 & 157 & 297 & 3,407 \\
\hline Auditorium Lights & 174 & 239 & 197 & 85 & 73 & 154 & 198 & 169 & 190 & 92 & 44 & 134 & 1,750 \\
\hline Emergency Lights & 227 & 215 & 215 & 174 & 180 & 186 & 196 & 223 & 224 & 240 & 179 & 183 & 2,442 \\
\hline Side Walk Lights & 483 & 417 & 383 & 344 & 370 & 414 & 454 & 531 & 562 & 601 & 577 & 478 & 5,614 \\
\hline Parking Lot Lights & 281 & 243 & 222 & 200 & 215 & 241 & 263 & 308 & 325 & 345 & 327 & 277 & 3,246 \\
\hline Total Equipment & 2,745 & 2,537 & 2,656 & 2,921 & 2,613 & 2,704 & 3,039 & 3,124 & 2,820 & 2,943 & 2,889 & 2,654 & 33,644 \\
\hline Receptacles & 546 & 619 & 741 & 868 & 836 & 883 & 1,167 & 1,094 & 655 & 716 & 622 & 583 & 9,329 \\
\hline Emergency Receptacles & 335 & 326 & 337 & 323 & 333 & 333 & 325 & 341 & 397 & 422 & 424 & 378 & 4,273 \\
\hline PV system Consumption & 396 & 346 & 313 & 279 & 301 & 334 & 360 & 424 & 487 & 525 & 544 & 440 & 4,747 \\
\hline Elevator & 223 & 194 & 197 & 151 & 142 & 148 & 153 & 175 & 191 & 214 & 228 & 200 & 2,216 \\
\hline Wastewater treatment & 93 & 108 & 95 & 139 & 41 & 51 & 61 & 81 & 82 & 92 & 83 & 108 & 1,033 \\
\hline Miscellaneous Equipment & 1,153 & 945 & 974 & 1,162 & 960 & 954 & 973 & 1,009 & 1,008 & 974 & 988 & 946 & 12,046 \\
\hline
\end{tabular}




\section{Appendix D: Seasonal Daylighting Analysis}

\section{D.1 Spring Equinox Performance}

NREL made the first set of daylighting measurements near the spring equinox (March 26 through March 30, 2001). Results from this spring equinox section can be applied to the fall equinox because the solar altitude angles are the same for both daylighting seasons. As described in Section 6.4, in addition to the continuous measurements, handheld measurements were made periodically in the atrium, the first-floor classroom, and in the second-floor classroom (on a finer grid). For the duration of the illuminance measurements during this study period, the electric lights were manually turned off in the classroom and the north office by disabling the occupancy sensors. The blinds were not used to shade the windows during the measurement period, unless noted.

Figure D-1 shows the time-series data for the outside horizontal illuminance during select days of the spring equinox test period.

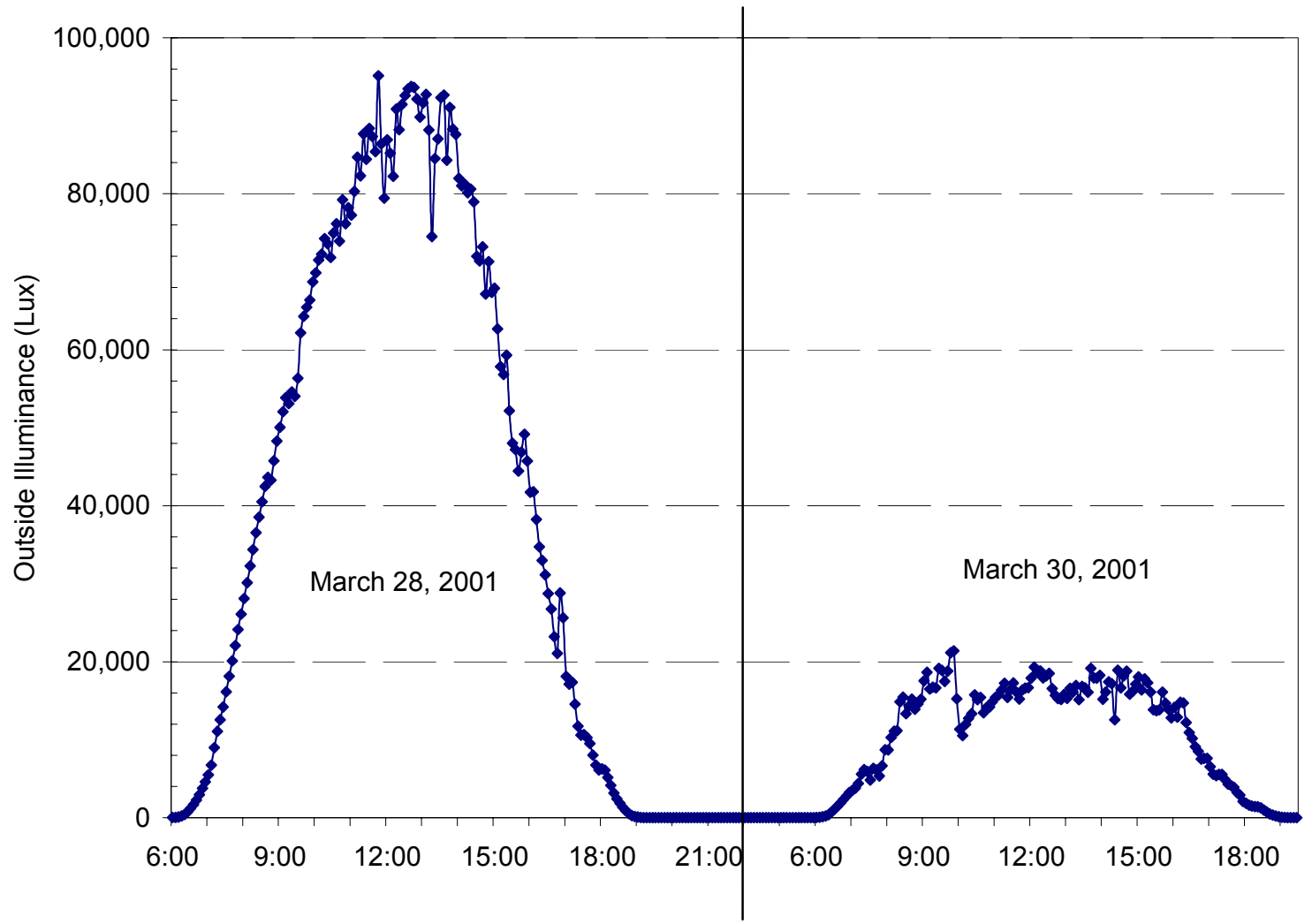

Figure D-1 Outside horizontal illuminance for a typical clear day and a typical cloudy day (March 28 and March 30, 2001, respectively)

On March 28, sky conditions were mostly clear, and on March 30, sky conditions were mostly overcast. Interior daylighting measurements are easiest to interpret on these definitive clear and cloudy days. When the outside illuminance is highly variable (partially cloudy), the interior measurements are also variable, increasing the interpretation difficulty.

Figure D-2 shows the time-series data for the second-floor classroom during the clear day near the spring equinox. The location of each sensor was illustrated in Figure 6-24. 


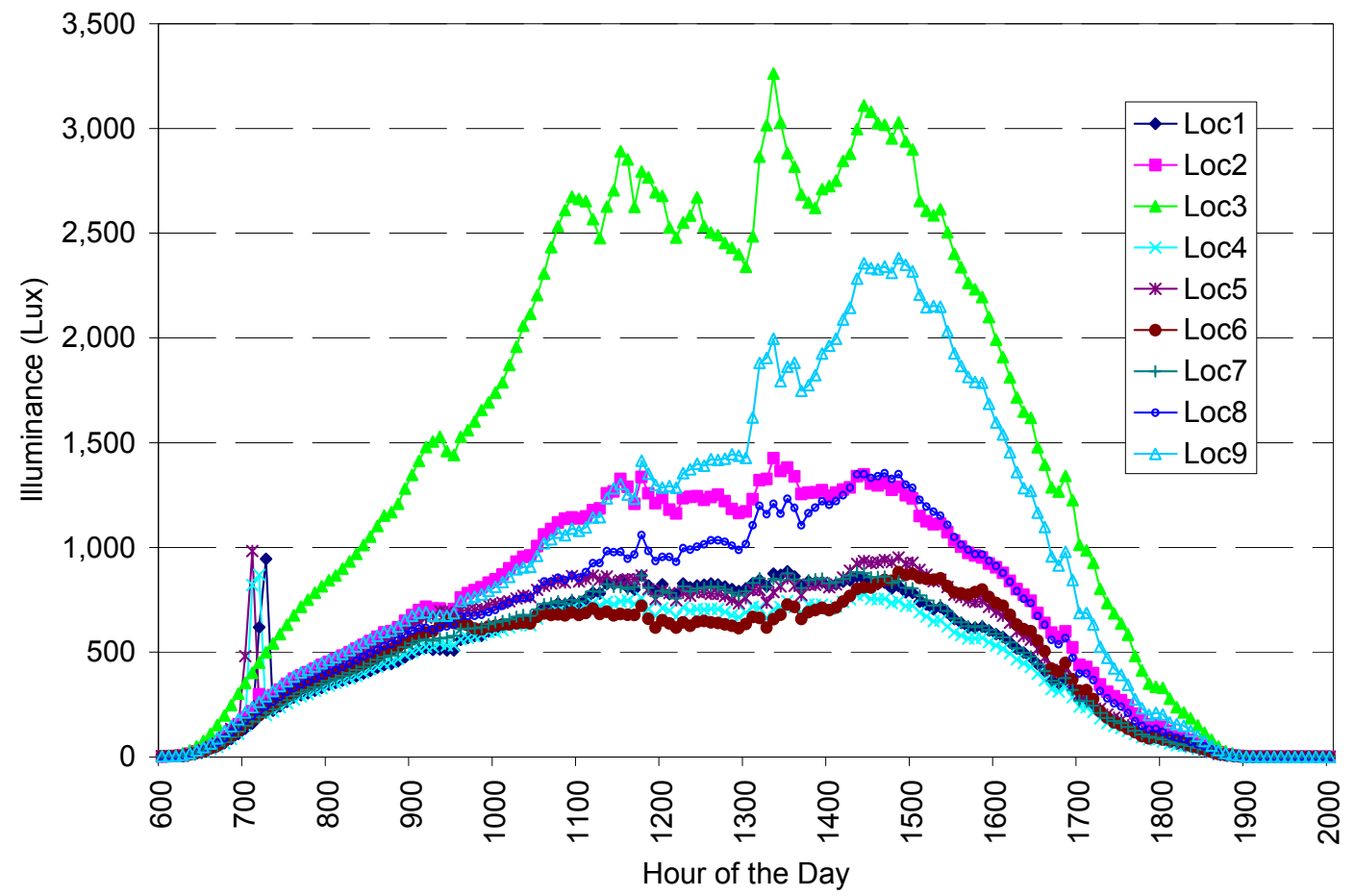

Figure D-2 Second-floor classroom illuminance measurements on a typical clear day

Illuminance levels for all measurement points are above 500 lux from about 9 a.m. until 5 p.m. Points closer to the windows have higher and more variable illuminance levels. All points more than $10 \mathrm{ft}(3 \mathrm{~m})$ from the windows are relatively uniform throughout the day. No electric lighting would be required for normal classroom tasks from about 8 a.m. until 5 p.m., as the minimum classroom illuminance is above the recommended illuminance level of 300 lux (IESNA 2000). In general, for outdoor illuminance greater than $30 \mathrm{klux}$, the illuminance from daylighting in the second-floor classrooms is greater than the minimum recommended illuminance levels. No direct-beam sunlight enters the second-floor south-facing fenestration from mid-March to mid-September between mid-morning and mid-afternoon, as the overhang completely shades the windows from direct-beam radiation. The mid-morning shading on March 28 is pictured in Figure D-3. 


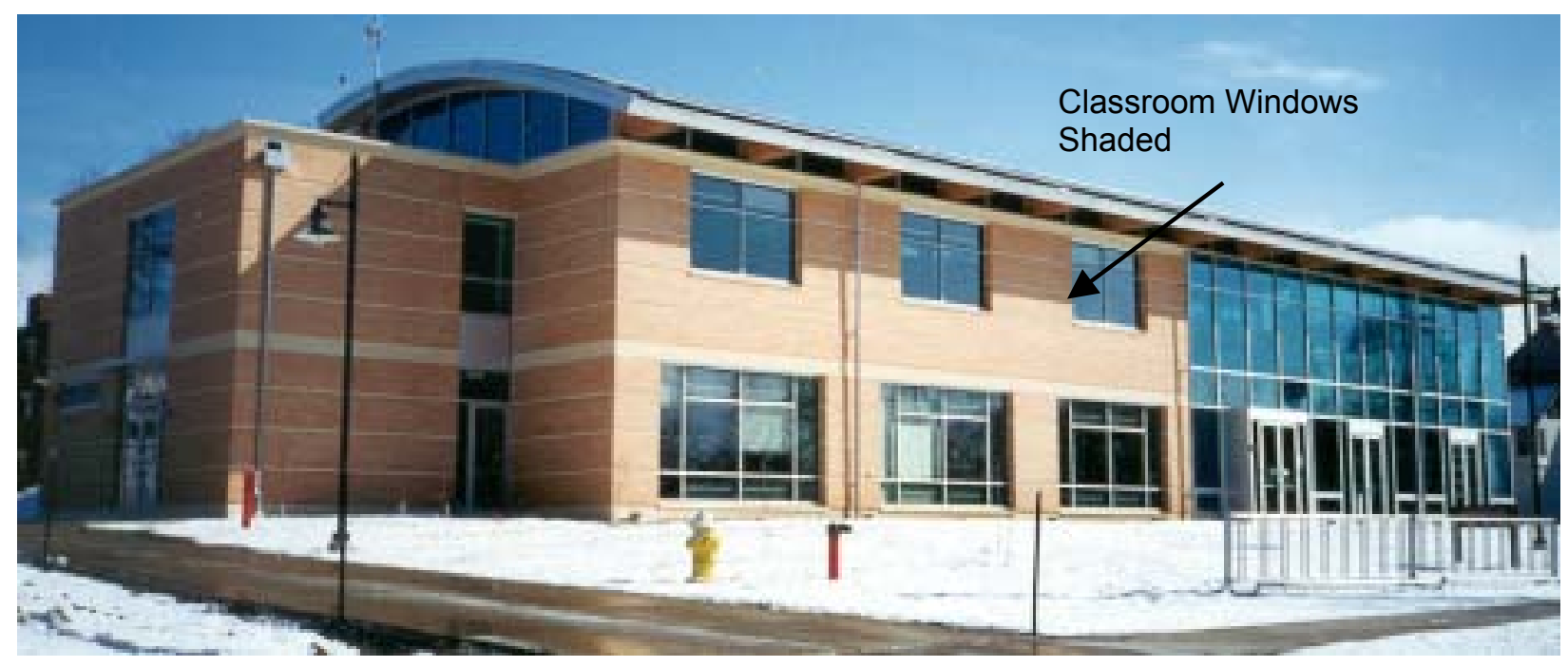

Figure D-3 Spring equinox second-floor shading at midmorning, March 28, 2001

Figure D-4 shows illuminance levels in the second-floor classroom for the typical cloudy day during the equinox daylighting season.

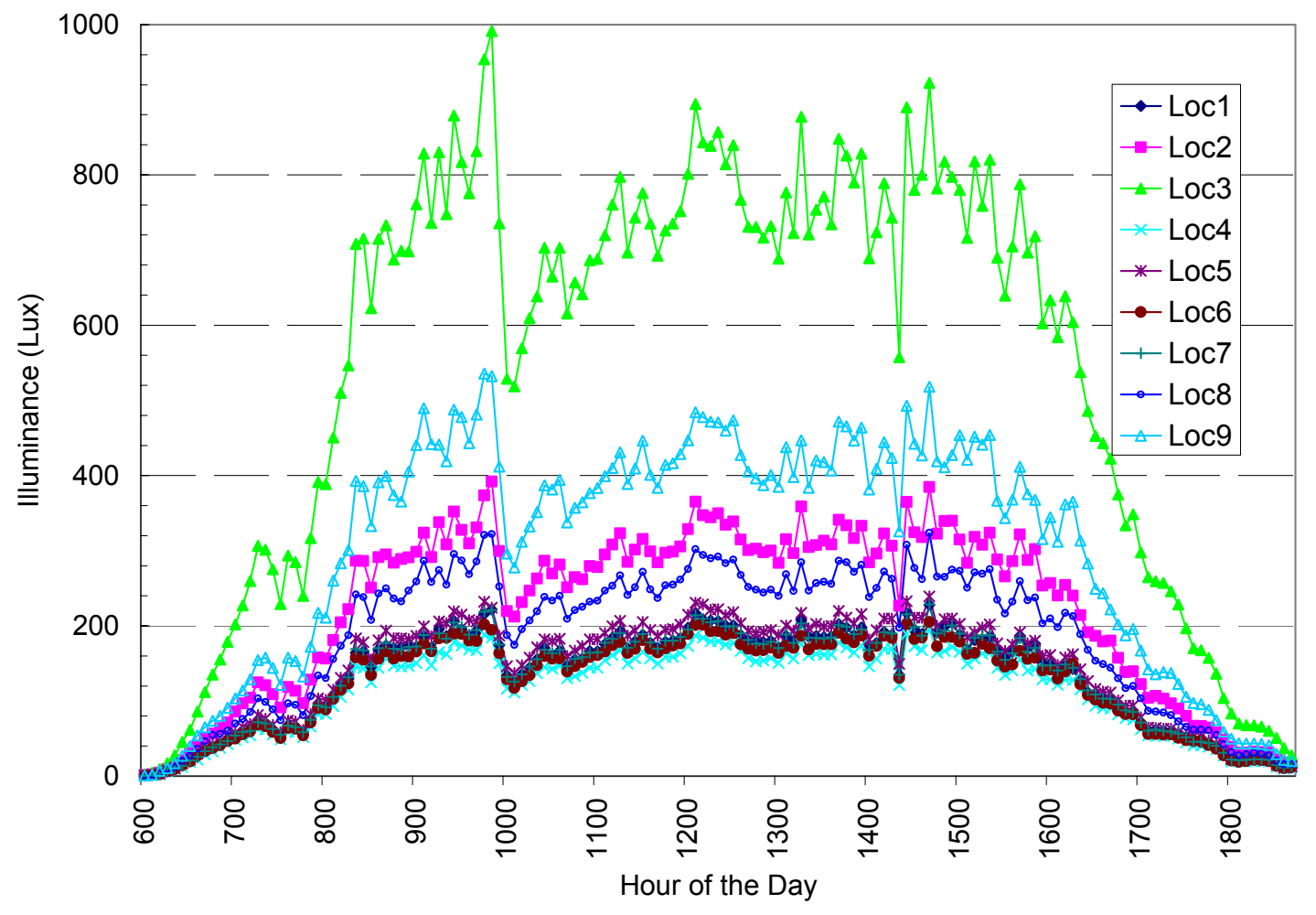

Figure D-4 Second-floor classroom illuminance measurements on a typical cloudy day

All measurement points away from the windows have relatively uniform and constant illuminance levels. Except near the windows, the illuminance is less than the recommended 300 lux. Occupants generally would choose to use electric lighting on cloudy days during the equinox daylighting seasons when the 
outdoor illuminance is below 30 klux. For the equinox daylighting seasons, daylighting alone can provide adequate illumination in the classrooms when the outdoor illuminance is greater than 30 klux.

Direct-beam sunlight does not enter the second-floor classrooms from March 22 to September 22. Directbeam sunlight does enter the zones that are not shaded resulting in potential glare problems. For example, in the first-floor classroom, the shades are typically used to control glare during sunny days. Figure D-5 shows the effect of adjusting the blinds in the first-floor classroom.

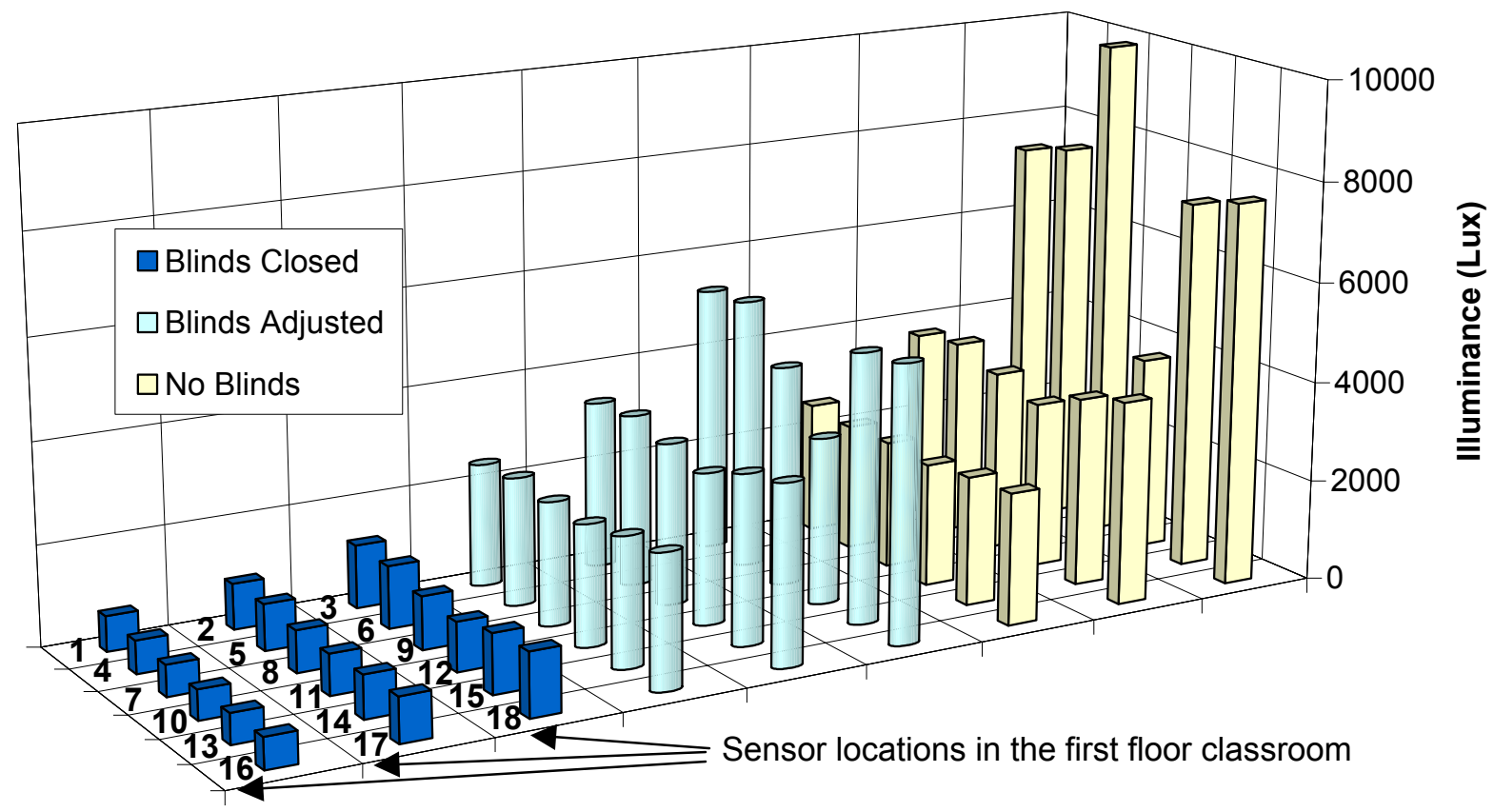

Figure D-5 Influence of blinds in first-floor classroom-12:10 to 12:25 p.m. on March 28, 2001

In the figure above, illuminance in the first-floor classroom is shown as a function of position for blinds up, blinds down to eliminate direct gain, and blinds fully closed. For the blinds closed measurements, the location of each measurement (1-18) is shown. The measurement positions for the blinds adjusted and blinds up are the same as the blinds closed, although they are not labeled. Uniformity across the classroom is improved and glare is eliminated when the blinds are adjusted compared to blinds up. Even when the blinds are fully closed, the illuminance level is still adequate for classroom visual tasks with all locations above 300 lux.

Figure D-6 shows illuminance measurements for the atrium, with measurements performed over the course of a day for varying sky conditions. Measurement locations are labeled for the 4:03 p.m. measurements. For other measurements, the locations are the same, although they are not labeled. There are very strong shadows with lots of direct gain, except for fully overcast sky conditions (4:03 p.m. measurements). This glare is not typically considered a problem, as the occupant use of this space does not require managed lighting levels. 


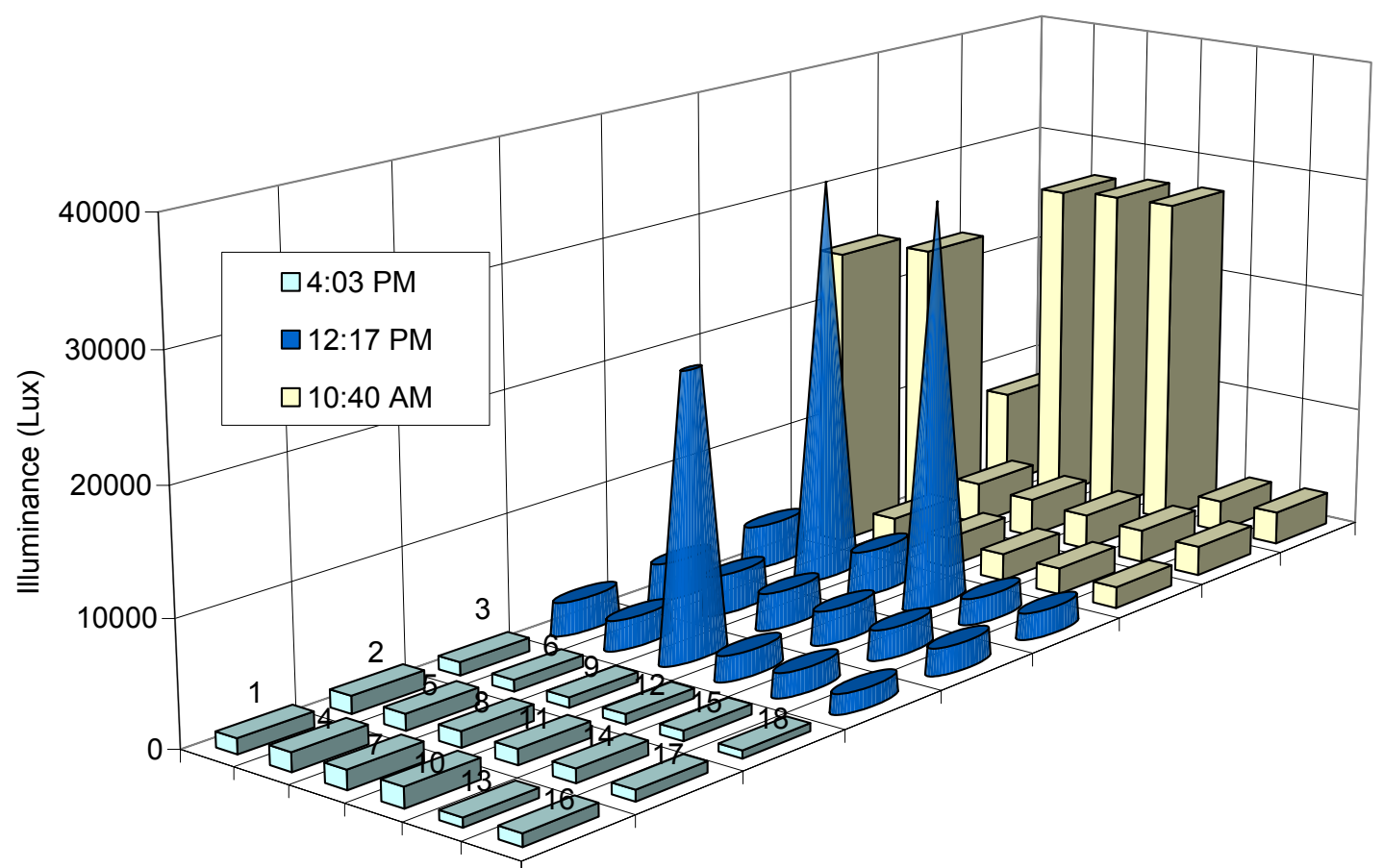

Figure D-6 Measured illuminance in atrium during a variably cloudy day, March 26, 2001

The minimum illuminance in the atrium at 4:03 p.m. during fully overcast sky conditions was 630 lux. The extensive fenestration allows for all the lighting needs to be met by daylighting during daytime hours.

\section{D.2 Summer Solstice Performance}

The next set of daylighting measurements occurred from June 18 through June 20, 2001. The primary difference during this time of the year is that the sun was near peak altitude angles. Shading devices and window locations dramatically affect indoor illuminance levels at the varying solar altitude angles.

Figure D-7 shows the outdoor horizontal illuminance over 2 days during the summer solstice daylighting test period. 


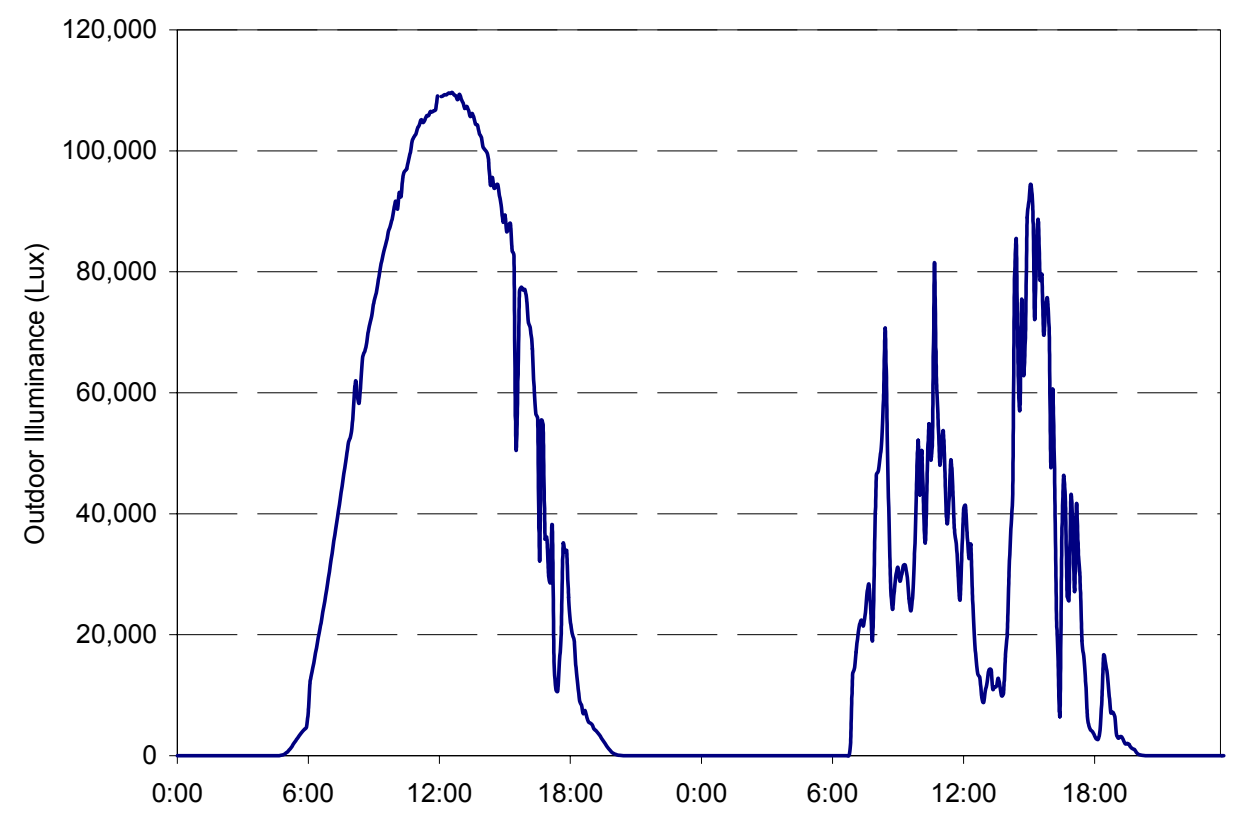

Figure D-7 Outside horizontal illuminance for June 19 and 20, 2001

June 19 was a mostly sunny day with a few clouds in the afternoon, and June 20 was a diffuse, mostly cloudy, hazy day with morning fog and mid-afternoon thunderstorms. Both days are ideal for a daylighting evaluation because there was a full range of exterior illuminance with constant sky conditions.

Figure D-8 shows the measured illumination data for the second-floor classroom during the clear and cloudy day near the summer solstice.

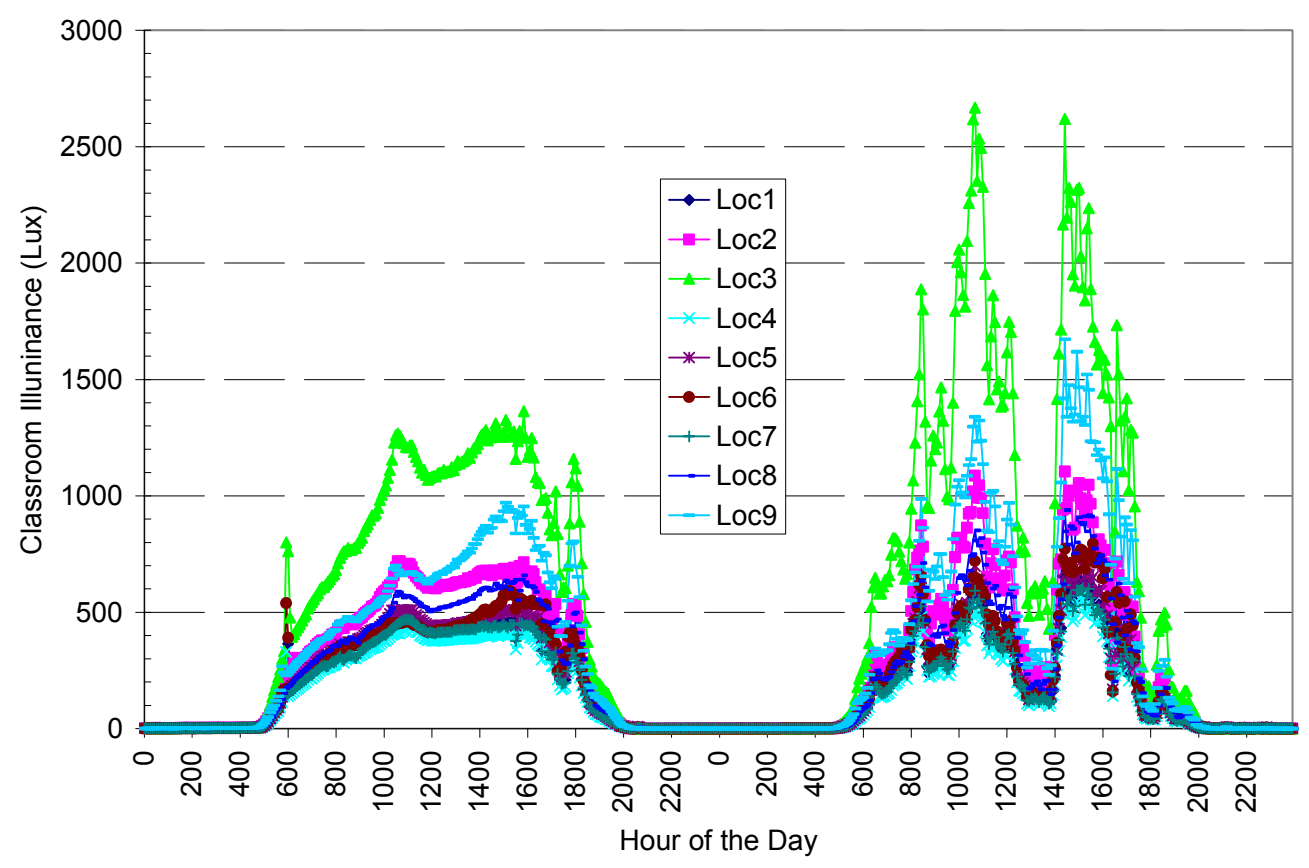

Figure D-8 Second-floor classroom illuminance for June 19 and 20, 2001 
During this time of year, no direct-beam sunlight enters the second-floor classrooms because of the shading from the overhang above the windows. Measured illuminance levels were greater than 300 lux from 9 a.m. until 5 p.m. The second-floor classroom is not completely daylit until the outdoor illumination exceeds 40 klux. For the cloudy days with diffuse sky conditions, more daylighting enters the second-floor classrooms as compared to a clear day when the direct-beam daylighting is completely shaded. To assess and compare the daylighting performance in the first-floor classroom, measurements at 12:20 p.m. on June 19, 2001 are shown in Figure D-9.

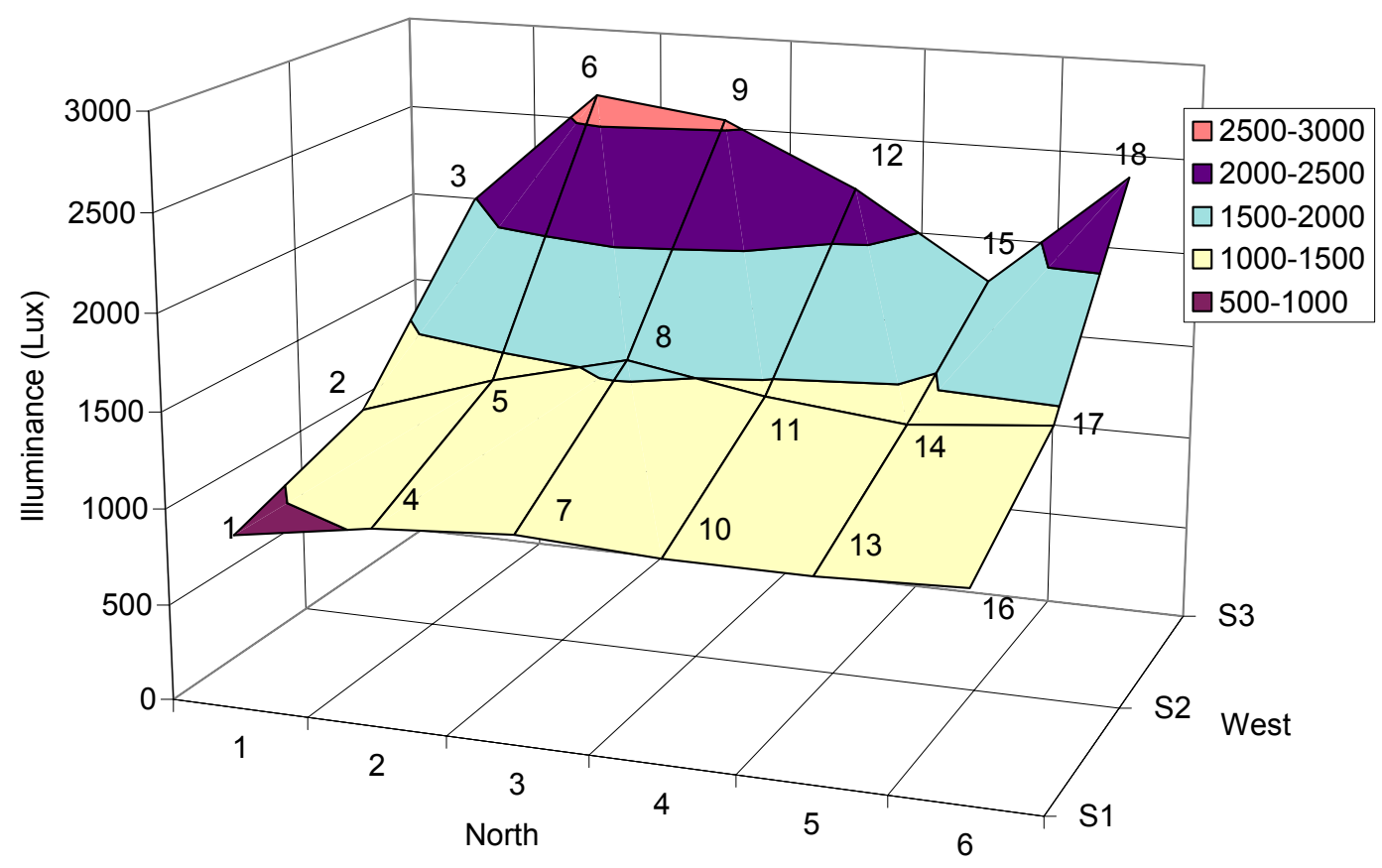

Figure D-9 First-floor classroom illuminance levels at 12:20 p.m. on June 19, 2001

In comparison to the second-floor classroom illuminance measurements taken at the same time, the overall illuminance in the first-floor classroom is about twice as high, but the distribution across the measurement grid is similar. The increased illuminance is due to the lower, brighter ceiling and larger south-facing windows in the first-floor classroom. The white ceiling also allows more daylight to be reflected deeper into the space. Figure D-10 and Figure D-11 show the difference between the high, dark ceiling in the second-floor classroom and the lower, brighter ceiling in the first-floor classroom. These comparisons allow for the assumption that whenever the second-floor classroom is measured as completely daylit, the first-floor classroom will be $100 \%$ daylit as well. Figure D-10 shows the second floor classroom looking towards the north-east. Figure D-11 is the first floor classroom looking towards the north-east. The south glass is to the right in both photographs. 


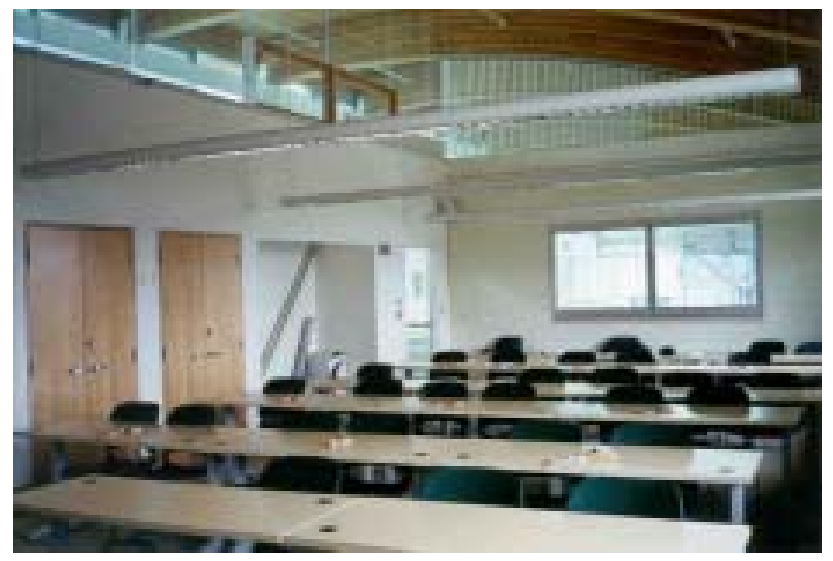

Figure D-10 Second-floor classroom showing daylighting without electric lights

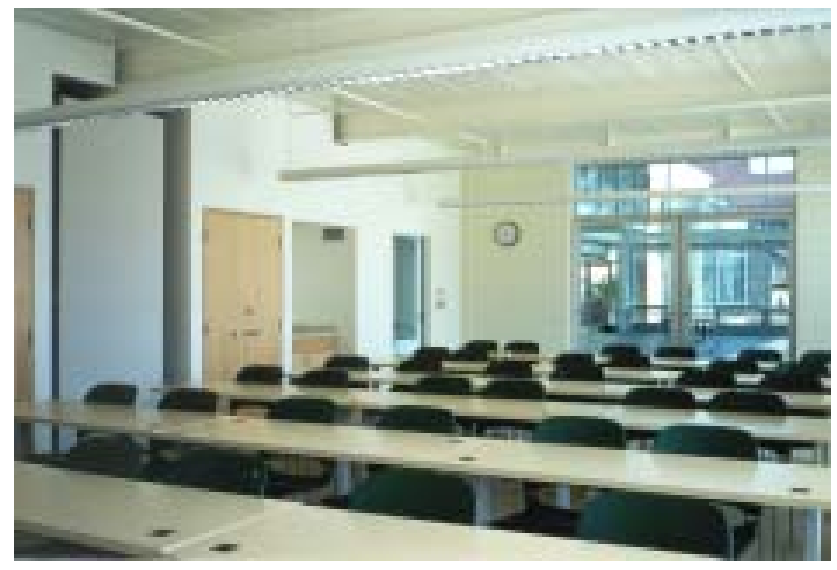

Figure D-11 First-floor classroom showing daylighting without electric lights

Figure D-12 shows the illuminance levels in the second-floor corridor and office during the measurement period. The daytime corridor illuminance levels range from 250 lux to 1250 lux over the 2-day period. The recommended illuminance level for typical tasks in a corridor is 100 lux. As the corridor lights were controlled to remain off if there is adequate daylight in the space, the measured illuminance levels in the corridor are fully dependent on the amount of daylighting available. Because of the clerestory windows in this space, the corridor is completely daylit when the outdoor illuminance is greater than $7.5 \mathrm{klux}$. The office illuminance is highly uneven over the measured period, as the diffuse light from the northern window provides adequate illuminance levels closer to the window but inadequate lighting near the middle of the office at location 14. Supplemental task lighting is needed in these office spaces to furnish adequate, uniform illuminance levels over the range of expected outdoor illuminance levels. 


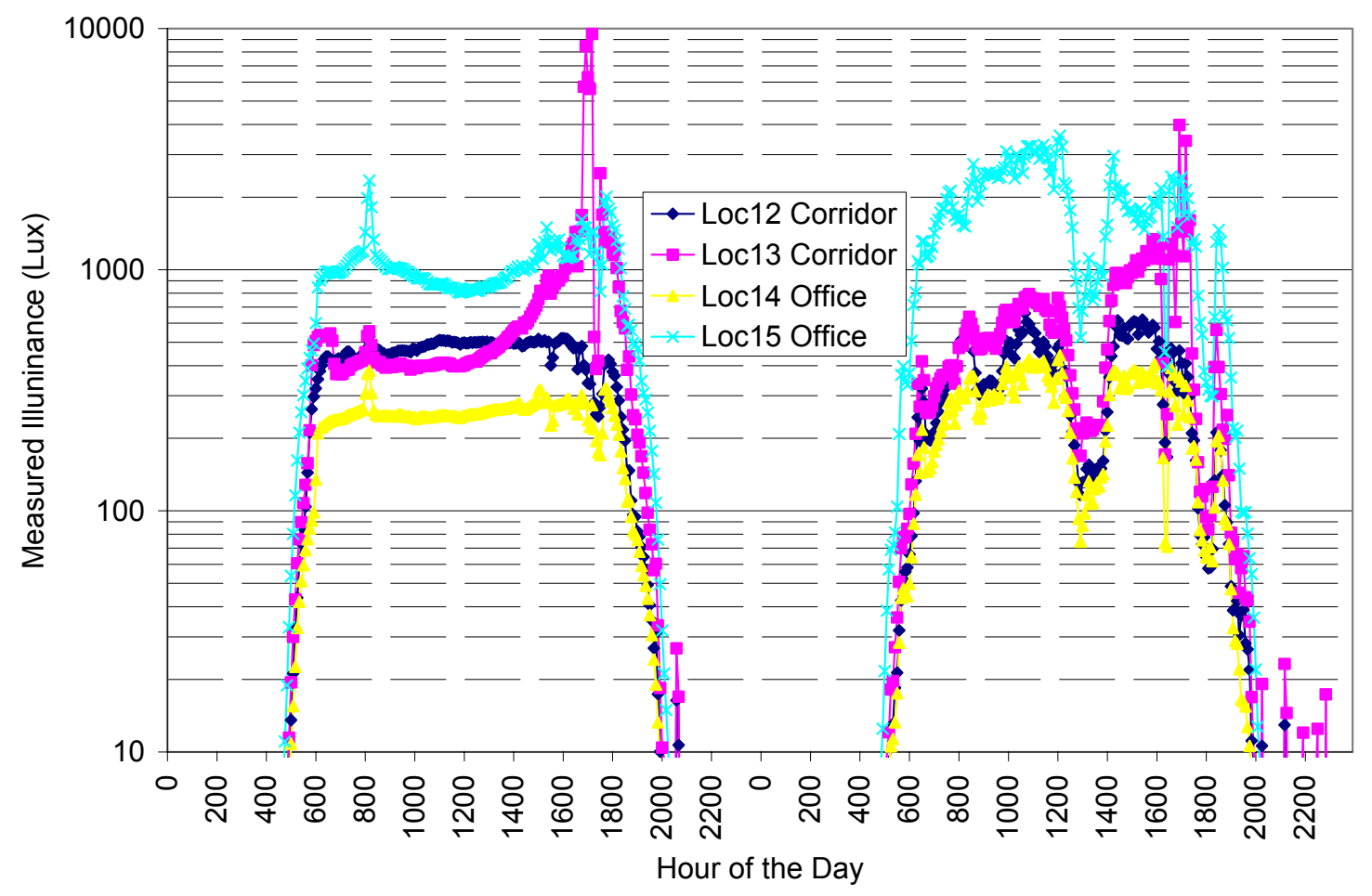

Figure D-12 Second-floor corridor and office illuminance on June 19 and 20, 2001

\section{D.3 Winter Solstice Performance}

Figure D-13 shows the outdoor horizontal illuminance during the winter solstice test period. January 3 was mostly sunny, and January 4 was partly cloudy in the early morning and sunny to partly cloudy in the afternoon. 


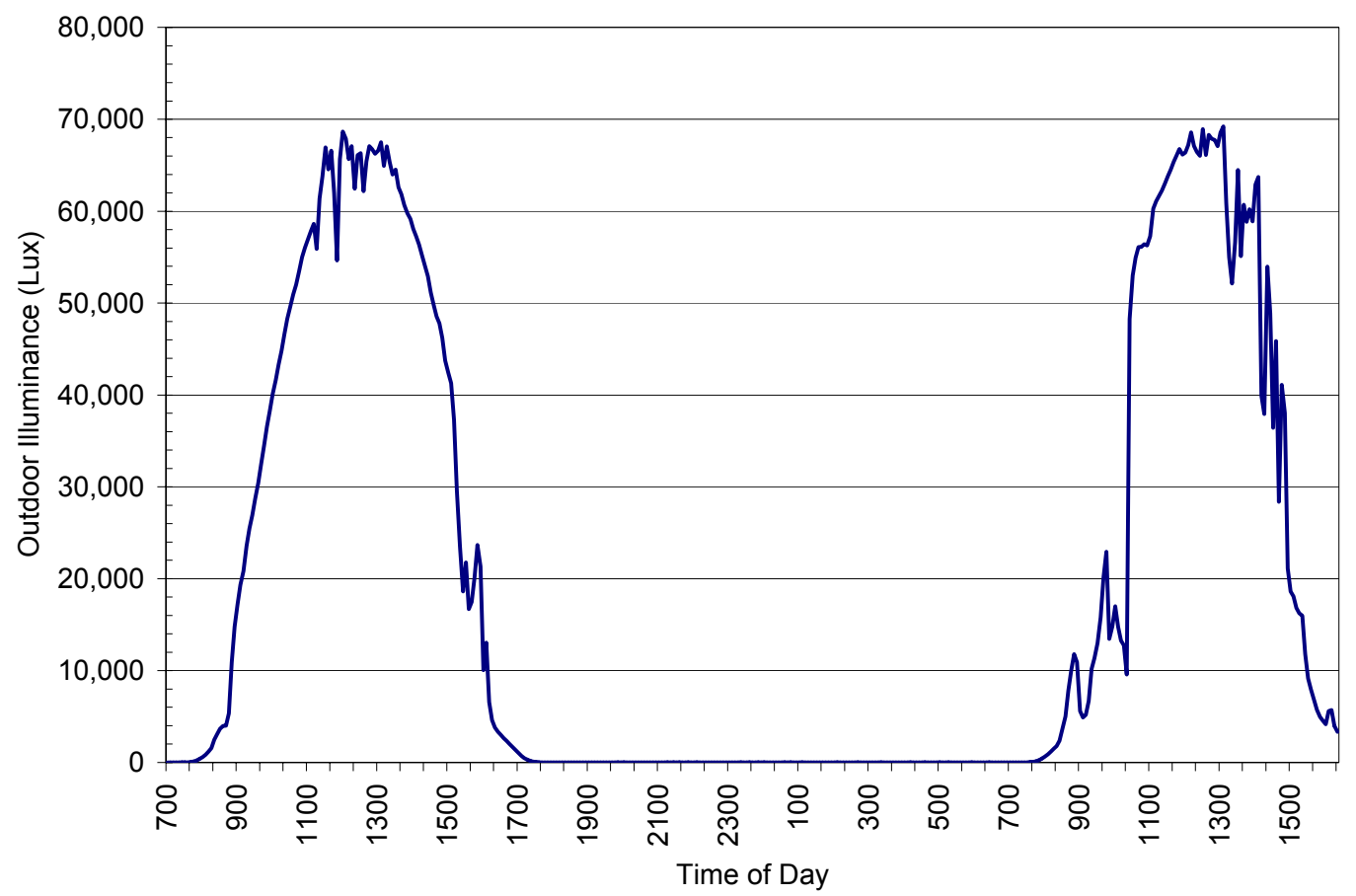

Figure D-13 Outside horizontal illuminance from January 3 and 4, 2002

Figure D-14 shows the time-series data for a typical clear day near the winter solstice.

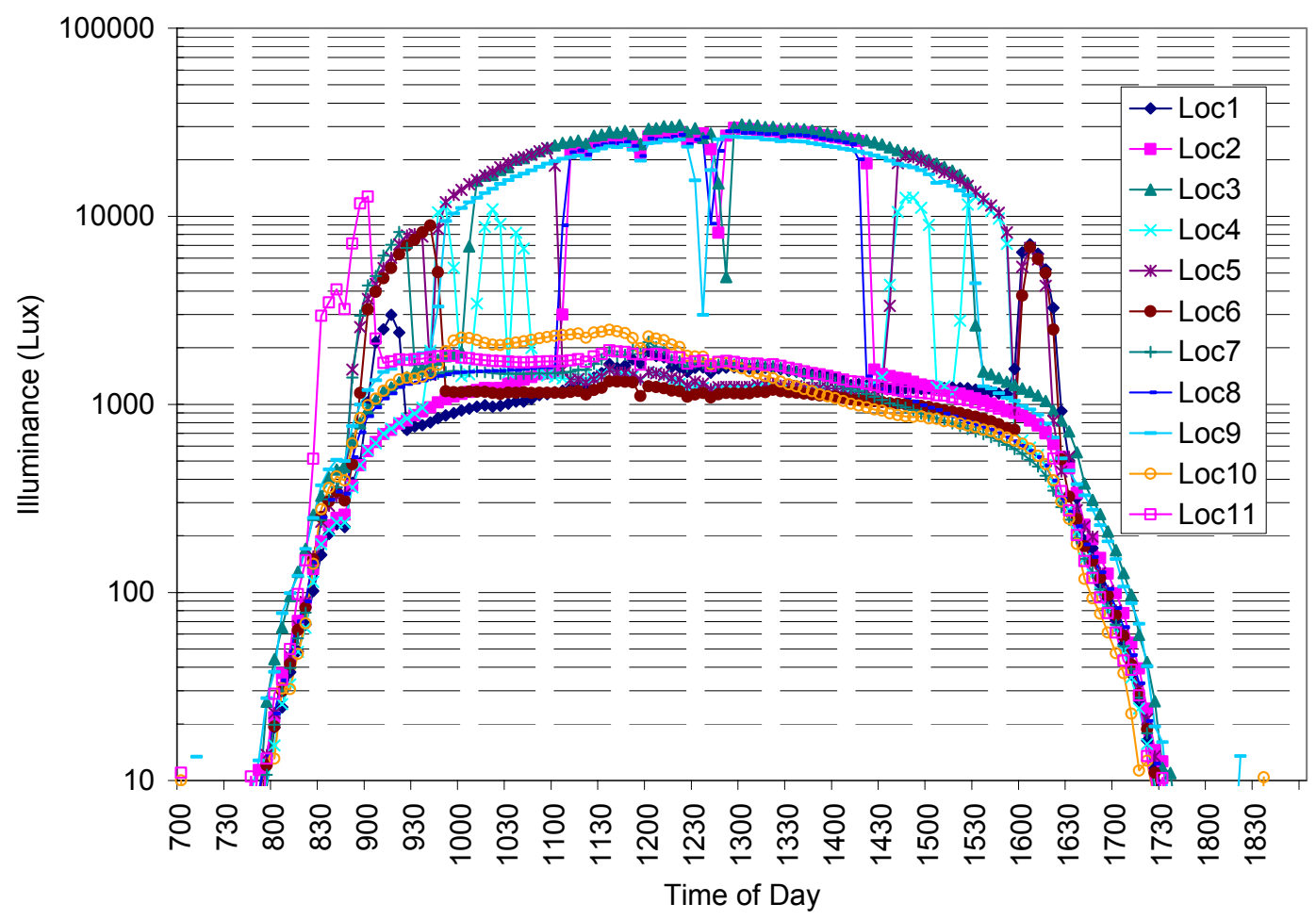

Figure D-14 Second-floor classroom illuminance on January 3, 2002 
Measured illuminance levels were above 500 lux from about 9 a.m. until 4 p.m. No electric lighting would be required for normal classroom tasks during this period. The vertical illuminance levels at the west end wall (Loc10 and Loc11) of the classroom indicate acceptable daylighting illumination. The overall classroom illuminance during a clear day is higher than any other daylighting season over the year. This is caused by direct-beam daylighting entering the classrooms. Points closer to the windows have higher and more variable illuminance levels. Points such as Loc3 and Loc9 have direct-beam radiation striking the desktop throughout most of the day. The usual response from users to this glare is to lower the blinds to eliminate the direct-beam into the space. Figure D-15 through Figure D-17 illustrate the effect of closing the blinds during periods of high glare. During an afternoon period (2 p.m. to 4 p.m.) on January 4, the blinds were closed and adjusted to block all direct-beam sunlight from entering the classroom. During this period with the shades closed, the illuminance levels at the points where glare was an issue (Loc3 and Loc9) were below 2000 lux.

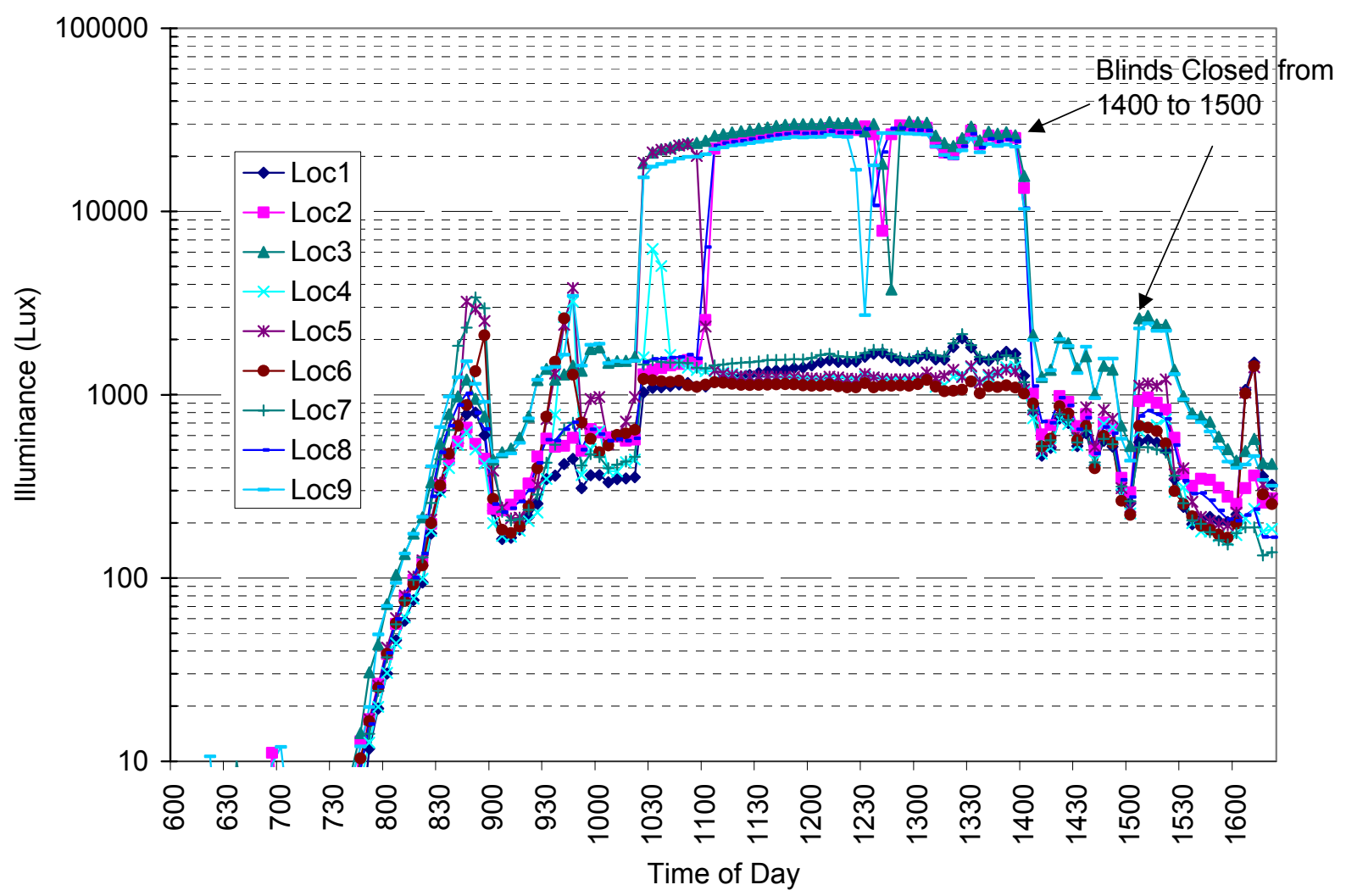

Figure D-15 Second-floor classroom illuminance on January 4, 2002

During the cloudy morning period (9:00-10:30 a.m.) of January 4, classroom illuminance levels ranged from 200 lux to 600 lux. Therefore, on cloudy days when the outdoor illuminance is below $12 \mathrm{klux}$, supplemental lights are necessary. For partly cloudy to sunny sky conditions, some or all of the blinds will probably be closed to reduce glare. Even when the blinds are closed during sunny sky conditions, the illuminance levels are still adequate for classroom visual tasks, with all locations measuring above 300 lux. The quality of daylighting during the winter depends on how the occupants control the blinds.

The measured daylighting distribution in the offices and corridor during the winter solstice was the same or better than the other measurement seasons. Further analysis of these spaces is not provided, as the relevant daylighting issues in these spaces are discussed in the previous the summer and spring daylighting performance sections. 


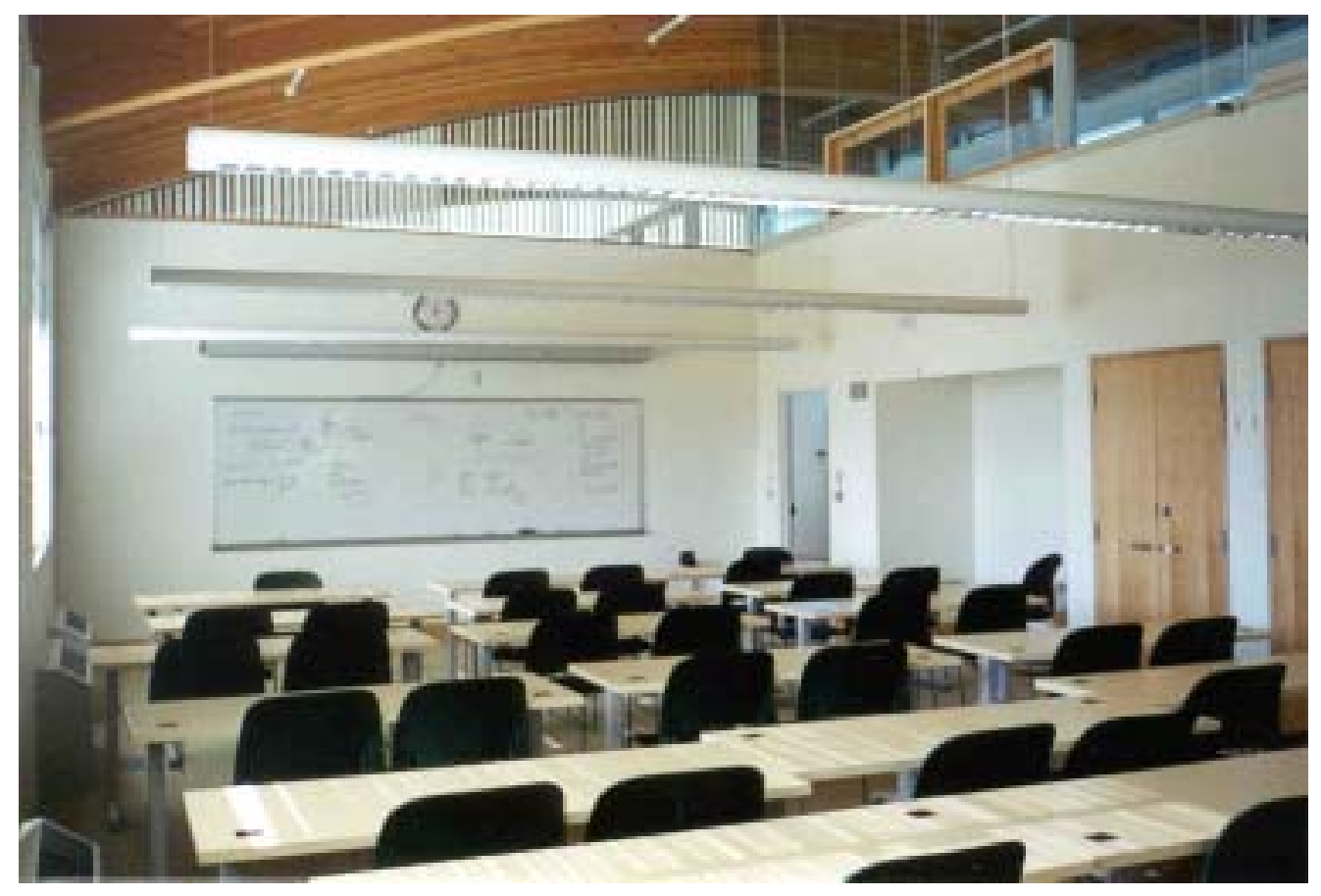

Figure D-16 Second-floor classroom looking west with blinds closed

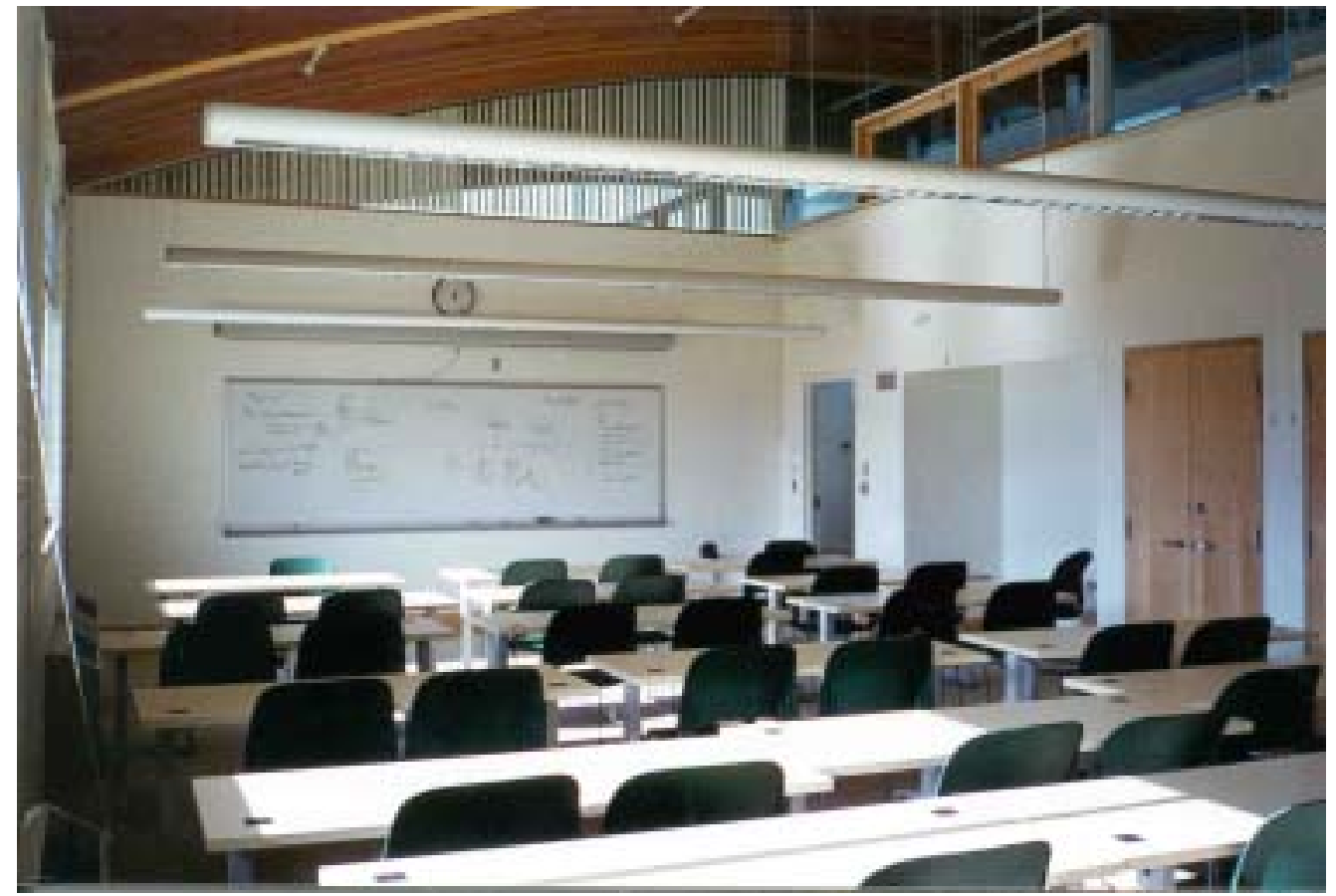

Figure D-17 Second-floor classroom with blinds open 


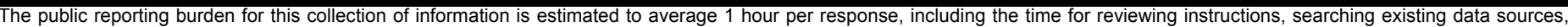

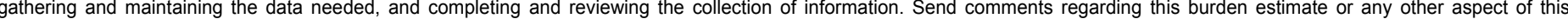

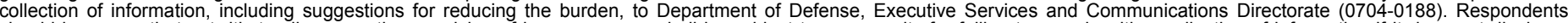

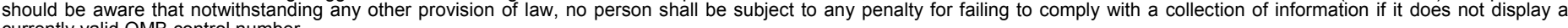
currently valid OMB control number.

PLEASE DO NOT RETURN YOUR FORM TO THE ABOVE ORGANIZATION.

\section{REPORT DATE (DD-MM-YYYY) November 2004 \\ 2. REPORT TYPE \\ Technical Report}

4. TITLE AND SUBTITLE

Energy Performance Evaluation of an Educational Facility: The Adam Joseph Lewis Center for Environmental Studies, Oberlin College, Oberlin, Ohio
3. DATES COVERED (From - To) 5a. CONTRACT NUMBER

DE-AC36-99-G010337

5b. GRANT NUMBER

5c. PROGRAM ELEMENT NUMBER

5d. PROJECT NUMBER

NREL/TP-550-33180

5e. TASK NUMBER

BEC3.4001

5f. WORK UNIT NUMBER

7. PERFORMING ORGANIZATION NAME(S) AND ADDRESS(ES)

National Renewable Energy Laboratory

1617 Cole Blvd.

Golden, CO 80401-3393
8. PERFORMING ORGANIZATION REPORT NUMBER

NREL/TP-550-33180

\section{SPONSORING/MONITORING AGENCY NAME(S) AND ADDRESS(ES)}

10. SPONSOR/MONITOR'S ACRONYM(S) NREL

11. SPONSORING/MONITORING AGENCY REPORT NUMBER

\section{DISTRIBUTION AVAILABILITY STATEMENT}

National Technical Information Service

U.S. Department of Commerce

5285 Port Royal Road

Springfield, VA 22161

13. SUPPLEMENTARY NOTES

14. ABSTRACT (Maximum 200 Words)

This final report gives findings from NREL's energy performance evaluation of the Adam Joseph Lewis Center for

Environmental Studies, Oberlin College, Oberlin, Ohio.

\section{SUBJECT TERMS}

Oberlin; Adam Joseph Lewis Center; Lewis Center; Ohio; high performance buildings; energy performance evaluation; commercial buildings; environmental studies

\begin{tabular}{|c|c|c|}
\hline 16. SECURITY & CLASSIFICATI & N OF: \\
\hline $\begin{array}{l}\text { a. REPORT } \\
\text { Unclassified }\end{array}$ & $\begin{array}{l}\text { b. ABSTRACT } \\
\text { Unclassified }\end{array}$ & $\begin{array}{l}\text { c. THIS PAGE } \\
\text { Unclassified }\end{array}$ \\
\hline
\end{tabular}

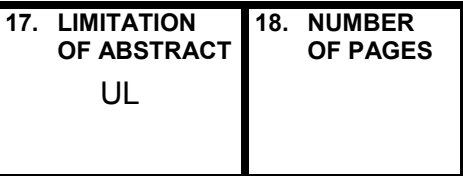

19a. NAME OF RESPONSIBLE PERSON

19b. TELEPONE NUMBER (Include area code) 